
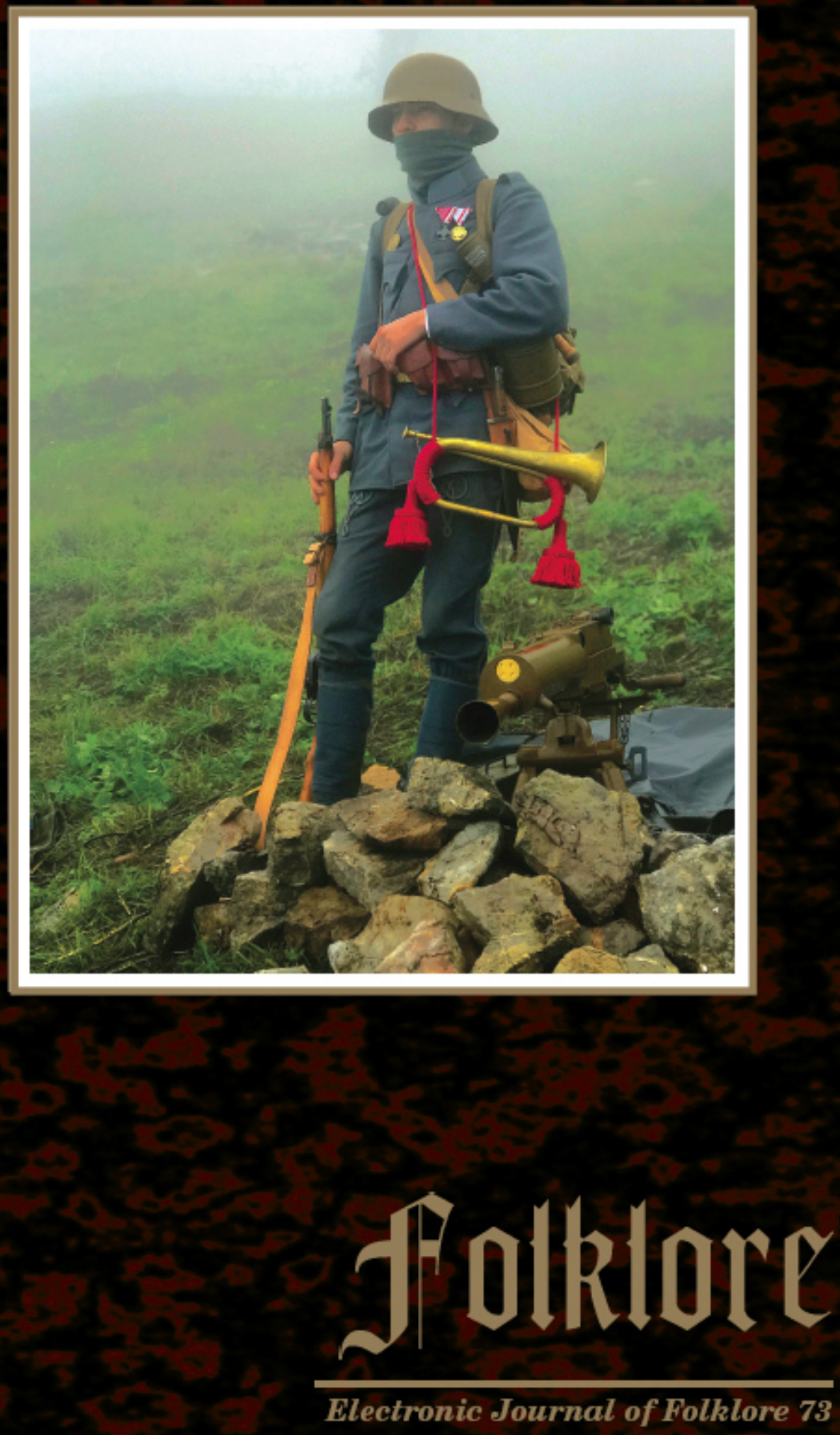


\section{Folklore}

Electronic Journal of Folklore http://www.folklore.ee/folklore Vol. 73

2018 
Folk Belief and Media Group of the Estonian Literary Museum

Estonian Institute of Folklore

\section{Folklore}

Electronic Journal of Folklore Vol. 73

Edited by Mare Kõiva \& Andres Kuperjanov Guest editors: Jurij Fikfak \& Božidar Jezernik

ELM Scholarly Press

Tartu 2018 
Editor in chief

Co-editor

Guest editors

Copy editor

News and reviews

Design

Layout
Mare Kõiva

Andres Kuperjanov

Jurij Fikfak \& Božidar Jezernik

Tiina Mällo

Piret Voolaid

Andres Kuperjanov

Diana Kahre

Editorial board 2015-2020: Dan Ben-Amos (University of Pennsylvania, USA), Larisa Fialkova (University of Haifa, Israel), Diane Goldstein (Indiana University, USA), Terry Gunnell (University of Iceland), Jawaharlal Handoo (University of Mysore, India), Frank Korom (Boston University, USA), Jurij Fikfak (Institute of Slovenian Ethnology), Ülo Valk (University of Tartu, Estonia), Wolfgang Mieder (University of Vermont, USA), Irina Sedakova (Russian Academy of Sciences).

The journal is supported by the Estonian Ministry of Education and Research (IUT 22-5), the European Union through the European Regional Development Fund (Centre of Excellence in Estonian Studies), the state programme project EKKM14-344, and the Estonian Literary Museum.

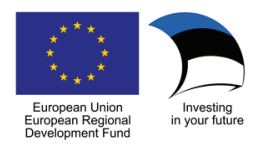

Indexed in EBSCO Publishing Humanities International Complete, Thomson Reuters Arts \& Humanities Citation Index, MLA International Bibliography, Ulrich's Periodicals Directory, Internationale Volkskundliche Bibliographie / International Folklore Bibliography / Bibliographie Internationale d'Ethnologie, Open Folklore, C.E.E.O.L., Scopus

\section{Editorial address:}

Folklore: Electronic Journal of Folklore

Vanemuise 42-235

51003 Tartu

Estonia

phone: $\quad+3727377740$

fax: $\quad+3727377706$

e-mail: folklore@folklore.ee

home page: http://www.folklore.ee/folklore

All rights reserved

(C) Estonian Literary Museum

Estonian Institute of Folklore

Authors

Design Andres Kuperjanov

According to Creative Commons licence BY-NC-ND 4.0

ISSN 1406-0957

doi:10.7592/FEJF2018.73 


\section{CONTENTS}

Introduction: The Cultural Heritage of the Isonzo Front

Jurij Fikfak, Božidar Jezernik

Historical Introduction: The Experience and Memory of Trenches

Near the Soča River

Marko Štepec

Memorialization of the First World War in the Landscape

of the Julian Alps

Jaka Repič

From the Hinterland: Commemorating the Centenary

of World War I in Bohinj

Tatiana Bajuk Senčar

Knowledge of Place in Three Popular Music Representations of the First World War

Miha Kozorog

Learning by Collecting: Amateur Collectors and Their

Shifting Positions in the Isonzo Front Heritagization and

Tourism Adaptation

Boštjan Kravanja

From the Editorial BoARd

Continuity and Revitalisation in Sacrificial Rituals

by the Eastern Udmurt

Part II. Collective Sacrificial Rituals by the Bashkortostan

Udmurt: Revitalisation and Innovation

Eva Toulouze, Ranus Sadikov, Laur Vallikivi,

Liivo Niglas, Nikolai Anisimov

Multi-Dimensional Borders in Narration

Tiiu Jaago

Metaphorical Integrations in Kurdish Riddles

Rahman Veisi Hasar, Ebrahim Badakhshan 


\section{News IN BRIEF}

Collecting Action "School Lore 2018" Exceeded All Expectations.

Reet Hiiemäe

Polar Readings 2018 on Board the Krasin Icebreaker.

Olga Stepanova, Alexandra Terekhina

Conference on Folk Narratives in Ragusa. Reet Hiiemäe

\section{Book REviEw}

Alliterative Histories. Jonathan Roper 


\title{
INTRODUCTION: THE CULTURAL HERITAGE OF THE ISONZO FRONT
}

\author{
Jurij Fikfak \\ Institute of Slovenian Ethnology \\ Research Centre of the Slovenian Academy of Sciences and Arts, Slovenia \\ e-mail:fikfak@zrc-sazu.si \\ Božidar Jezernik \\ Department of Ethnology and Cultural Anthropology \\ Faculty of Arts \\ University of Ljubljana, Slovenia \\ e-mail: bozidar.jezernik@ff.uni-lj.si
}

\begin{abstract}
One of the greatest, most tragic, and largely overlooked campaigns during the First World War was the Isonzo Front, which ran through an area inhabited by an ethnic Slovenian majority and, in the part along the southern reaches of the Isonzo River, by Italians, Friulians, and Germans. The region was part of the pact between the Triple Entente and Italy, which declared war on Austria-Hungary in 1915. This was a territory that is believed to have been visited by Dante Alighieri and that was described by Ernest Hemingway in one of his novels. This issue of Folklore: Electronic Journal of Folklore is dedicated to the First World War - specifically, the use and production of cultural heritage during that period - with an emphasis on a lesser-known front in the "non-West". According to John R. Schindler, the reasons for neglecting and forgetting this front, which involved over a million soldiers, over 300,000 of whom were killed in battle, lie in the fact that "[f]or most English-language historians, battles and campaigns of the Great War that did not happen on the Western Front or involve English-speaking troops apparently are not worth exploring" (Schindler 2001: xiii). Consequently, all the horrors of war and human victims have also been forgotten alongside it. The area that became part of Italy after the war has become the subject of various heritage discourses, strategies, and practices of the winners (i.e., Italians) and the losers (i.e., non-Italians).
\end{abstract}

Keywords: Caporetto, cultural heritage, Great War, Hemingway, Isonzo Front, landscape, memorials, memories, monuments

Between 2014 and 2018, many events took place in Europe in connection with the hundredth anniversaries of the First World War: the anniversary of its beginning triggered by the assassination in Sarajevo, commemorated in 2014; 
the anniversary of Italy entering the war on the English and French side, commemorated in 2015; the anniversary of the US entering the war, commemorated in 2017; and the centenary of the end of the war in 2018. The available online information on books and websites discussing this topic largely depends on or is defined by the country or region from which the inquiry is made, and it partly also depends on whether the search string used is "Great War" or "First World War". In the English-speaking context, the starting point is the Balkans, also referred to as "the powder keg of Europe", and the main emphasis is on the Western Front and the British and French victims. At the same time, it is also true that more substantial commemoration first began on the Western Front, by erecting churches and memorials immediately after the war (e.g., in Ypres), and that one of the first commemorative and symbolically reconciliatory ceremonies took place in 1984 between François Mitterrand and Helmut $\mathrm{Kohl}^{1}$ at the site of the Battle of Verdun, where around 300,000 soldiers were killed on both sides.

One of the greatest, most tragic, and largely overlooked campaigns during the First World War was the Isonzo Front, which ran through an area inhabited by an ethnic Slovenian majority and, in the part along the southern reaches of the Isonzo River, by Italians, Friulians, and Germans. The region was part of the negotiations and the agreement between the Triple Entente and Italy, which declared war on Austria-Hungary in $1915 .{ }^{2}$ Legend has it that this territory was visited by Dante Alighieri (Kozorog 2012), and because of this alone it was considered part of the Italian territorial horizon in Italian public discourse, which is also testified to by one of the tragic heroes in Hemingway's novel A Farewell to Arms, who perceives the region as a part of Italia, that will "return to the splendors of Rome" (Hemingway 2014 [1929]: 102).

According to John R. Schindler, the reasons for neglecting and forgetting this front, which involved over a million soldiers, over 300,000 of whom were killed in battle, lie in the fact that "for most English-language historians, battles and campaigns of the Great War that did not happen on the Western Front or involve English-speaking troops apparently are not worth exploring. Thus the Isonzo, the worst campaign of the First World War, not to mention one of the most historically significant, has been forgotten" (Schindler 2001: xiii). All the horrors of war and human victims were also forgotten along with it.

The oblivion on the side of historians is defied by the literary experience provided by Ernest Hemingway in his novel A Farewell to Arms, which is one of the first generally known associations that people make with the developments that took place on the Isonzo Front from 1915 to 1917. On the one hand, the persuasiveness of the novelist, a Nobel prizewinner, makes it possible to identify very diverse ways in which individuals experienced the war and, on 
the other, it deceives the reader into believing that the literary hero and the writer are one and the same person. What occurs is what Hemingway himself describes as the power of absolute truth that can be provided by a good writer. When comparing what really happened and what is believed to have happened, the latter is much more convincing and thus the reader ascribes what a literary character did, was doing, or experienced to the writer himself. His story about someone else becomes an autobiography to the reader.

The reader can get an idea of what Hemingway experienced and where he was during that period, but in any case his direct language, which combines the journalistic or Kansas City Star "staccato style" with a naturalistic literary style, makes the experiences of his literary hero, Tenente (Lieutenant) Frederic Henry, on the Isonzo Front from mid-1916 to 1917 or up to the Battle of Caporetto tangible and realistic. In this twelfth battle of the Isonzo, the AustroHungarian and German troops pushed the Italians beyond the Piave River and the Italians returned to their old and new positions only at the end of 1918. In a way, this involves narrative "objectivity" that prevails over subjectivity and at the same time does not allow or permit moral judgments. However, this play of different views and premises also has room for approaching reality, and for "detachment", "the truth", and "legend".

In the journal Folklore: Electronic Journal of Folklore, mention must by all means be made of at least one legend created by combining stories, various time periods, and spaces. In a BBC TV documentary about Hemingway's travels and activities, Michael Palin defined this technique as a combination of "romance and reality", in which anything is possible. And so, the first legend, according to which the story of Hemingway's main hero, Tenente, is actually the life story of Hemingway himself, also gives birth to other legends. One of the more extraordinary ones says that he was wounded on the Isonzo Front and treated at Hiša Franko. This legend is also included in the presentation of Hiša Franko, one of the best Slovenian and European restaurants. When reading about the restaurant and the Kobarid Museum, what the reader constantly has before the eyes is the famous writer and Nobel prizewinner and not the eighteen-year-old that was delivering chocolate and cigarettes in Fossalta di Piave, a town over a hundred kilometers from the Isonzo Front, and was hit by trench mortar shell in July 1918 - that is, when the Isonzo Front was already over.

The fact that Ernest Hemingway only came to this area at least one year after the events described in his novel inspired a thorough geographical and historical analysis of the work by Branko Drekonja and Aleksander Jankovič Potočnik (2012). The fact that the novel was overly accurate on the one hand and overly vague on the other suggests that it was most likely also created with the help of the informant from the field and that it was completed after 1927, 
when Hemingway visited the area. At that point this territory was already part of Italy, which had Italianized the names of settlements and people as part of its fascist policy. Thus, despite the fact that the fascist regime did not accept the novel that is in many ways anti-war text, and did not permit its translation, this exceptional work about the Isonzo Front implicitly affirms the neocolonial concept to some extent.

But what are the Isonzo Front, Hemingway, memorials, nature, music, and cultural heritage doing in this issue of Folklore: Electronic Journal of Folklore, dedicated to the Great War? Because of its title and subject matter alone, the journal is a metaphor for both the imagination, which creates and enriches tradition, and tradition, which stimulates imagination; the interplay of both makes it possible to become familiar with and use heritage. Within this context, the use and production of heritage with regard to the First World War, to which the articles in this issue are dedicated, are likewise part of the discourse about imaginations and concrete practices and strategies. At the same time, the articles in this issue are dedicated to a special, tragic, and forgotten territory (cf. Stepec 2018). In this thematic issue, ${ }^{3}$ the Isonzo Front and the developments taking place on this front and in connection with it form a chronotopic basis and background for discussions on cultural heritage, perception, and reception from various research premises that seek to provide traces (Ginzburg 2012) and at the same time testify to the ambivalence and polyvalence of the research object or subject itself.

In the introductory article, "The Experience and Memory of Trenches near the Soča River" Marko Štepec (2018) outlines not only the history of the battles taking place on this front, but also all the tragedy of life along the front, supplying the front, and so on. For example, the information that one soldier required the support of five people in the hinterland alone testifies to the magnitude of this war and the inclusion of the civilian population in the battles. During the first five battles, the frontline between the two armies remained practically the same, but then in August 1916 the Italian forces conquered Gorizia and the Austro-Hungarian forces also had to retreat from the Doberdò Plateau to the new defense line in the Karst region. However, during the twelfth offensive, or the Battle of Caporetto, the Austro-Hungarian forces reinforced by German units defeated the Italians and forced them to retreat all the way to the Piave River. Upon the collapse of Austria-Hungary in October 1918, the Italians, backed by the Allied powers, recovered the territory up to the Postojna Gate - that is, the border legalized by the 1920 Treaty of Rapallo concluded between Italy and Yugoslavia. The demographic structure of the area changed significantly because many Slovenian settlements lost men both young and old on the front. Under Italy (i.e., a winner of the First World War), the memories of Slovenian 
residents (i.e., the losers) were the more painful; the experiences of their losses and the feelings accompanying them became intimate, a matter of an individual family or village, and the subject of mourning at village cemeteries.

As part of the project Cultural Heritage of Interpretation and Reinterpretation, special attention was directed to the landscape affected by war. The Upper Soča Valley contains many well-preserved remains from the Isonzo Front battlefields, which provide a special type of landscape experience. Many monuments, signs, and inscriptions across the land (Ingold 2000; cf. Tilley 1994) evoke wartime memories through contemporary "authentic" forms of landscape experience (Selwyn 1995). Visitors can stroll through the fields where the battles took place, enter a shaft, or climb to the bottom of a preserved trench to relive the claustrophobic experience of a soldier observing the enemy on the other side. They can stop by the memorials dedicated to known and unknown soldiers that fell on the front (e.g., the wrongly convicted and executed residents of Idrsko killed by the Italians during an unsuccessful offensive). All these routes, locations, and objects that emerged during the war have been the subject of various discourses, among which mention should be made of the activities at the level of local communities, the more official discourses of governing and national institutions, and diverse, primarily European, international programs and projects throughout various periods. On the one hand, all this contributed to evoking memories and providing traces and, on the other, it altered the interpretation of their history and collective memory. The ways of perceiving and shaping the wartime and peacetime memory landscape reflect the political process of reinterpretation and production of local, regional, national, and European history and memory.

Between the two world wars, the area of today's Slovenian Littoral belonged to the Kingdom of Italy. However, it should be mentioned that the first monuments in this area were already created during the war. A unique example of the Secession, Church of the Holy Spirit at Javorca (near Tolmin), ${ }^{4}$ was designed and built in 1916 in honor of Austro-Hungarian casualties. In 1916 another religious object was created, the mosque in Log pod Mangartom, built by mostly Muslim Bosnian soldiers. After 1918, when the area was annexed by Italy, numerous monuments arose in memory of Italian sacrifices. The official, distinctly fascist, rhetoric legitimized the Italian colonial positions and symbolically materialized them through large memorials to Italian soldiers erected in Redipuglia, Oslavia/Oslavje, and Kobarid itself - the town that continues to be associated with the great Italian defeat of 1917. After 1945, the new state of Yugoslavia became responsible for the main care for monuments dedicated to the memorialization of events and heroes of the Second World War. Many Italian monuments, due to the experience of fascism, fell into ruin; however, 
even the Slovenian monuments of the First World War were not maintained. Under the communist regime, the memories of the First World War and its victims were pushed into the background. This is also attested by the fact that the first campaigns for collecting weapons and other artefacts from the First World War were only created as part of private initiatives. In the mid-1980s, the idea of building a museum developed, leading to the establishment of the Kobarid Museum ${ }^{5}$ as the central unit dedicated to the memory of the First World War in the early 1990s. In the region of the Isonzo Front, the production of First World War heritage is especially active today and comprises many institutions and organizations, local, national, and private, as well as initiatives and collections gathered by various individuals.

Similar to the Western Front, the Isonzo Front has become a symbolic memory landscape, where visits to routes, monuments, and museums shape personal and local identities and the local or national memory of the First World War (Saunders 2001). Various stakeholders are taking care of cemeteries and restoring monuments that decayed under communist Yugoslavia. Many private and public museum collections were established; the restoration of military infrastructure and logistics has reconstructed the wartime memory landscape, and much has been done to research and prepare military casualty records for public use. Several international associations have been included, and many programs and initiatives are taking place. Tourism and the development of memorialization at the local level and state protocol at the national level are the two main functions.

One of the internationally most successful projects of this kind is the Walk of Peace trail, established in 2000, which is a research-based extension of previous heritage initiatives. Its main contribution is the reshaping of the mountain landscape, which, through the restoration of bunkers, trenches, and military routes, is acquiring the structure of an outdoor museum with an authentic historical landscape character. Routes of former military significance are today reinterpreted as memorial routes which also offer recreational and sightseeing information. At the same time, the landscaping project is acquiring an increasingly protocol function. In 2012, the Slovenian and Italian presidents, Danilo Türk and Giorgio Napolitano, became honorary patrons of the Walk of Peace trail, which runs from the Julian Alps to the Adriatic Sea and is also Slovenia's flagship contribution to the Pan-European formal remembrance of the centenary of the start of the Great War. The Walk of Peace trail includes the most beautiful Slovenian First World War memorial: the church at Javorca, which is a symbol of calling for reconciliation. Although First World War heritage bears many particular meanings, it can also act as a vessel for the active cooperation of new EU peripheries in contemporary European ideological landscapes. In the national sense, it thus represents a new Europeanization of Slovenian history. 




Figure 1. Simulation of the twelfth battle or the Battle of Caporetto at the Kobarid Museum in October 2017. Photograph by Jurij Fikfak.

For the case of the Upper Soča Valley region and the broader Julian Alps, the researchers thus examined the ways that the landscape is being changed through the restoration and (re)inscription of First World War monuments, and the social perception and influences of the memory landscape of wartime and peacetime. Using the ethnographic and historical approaches, they explored the physical and symbolical landscape, its experiencing by different participants or visitors (the research community, tourists, and hikers), and the stories (or discourses) of the landscape as they are produced by experts, institutions, amateur collectors of First World War memorabilia, locals, and visitors. The focus was on monuments, locations, routes of remembrance (memorials, cemeteries, churches, mule tracks, etc.), practices, politics of remembrance (e.g., commemorations at the local or state level, and museums), and narratives and discourses as spheres of interpretation.

In the article "Memorialization of the First World War in the Landscape of the Julian Alps", Jaka Repič (2018) addresses issues of memorialization processes and heritage construction, which are inscribed into the landscapes of the Isonzo Front in Slovenia. The most common conclusion made by historians is 
that landscapes tend to be static or even empty, and contain imprints of many military actions. As such, they should be part of the practices of memorialization. On the other hand, Nicholas Saunders, a British anthropologist and archaeologist, stresses that landscapes cannot be separated from human experiences; they are all part of the complex world of relationships, memories, and histories.

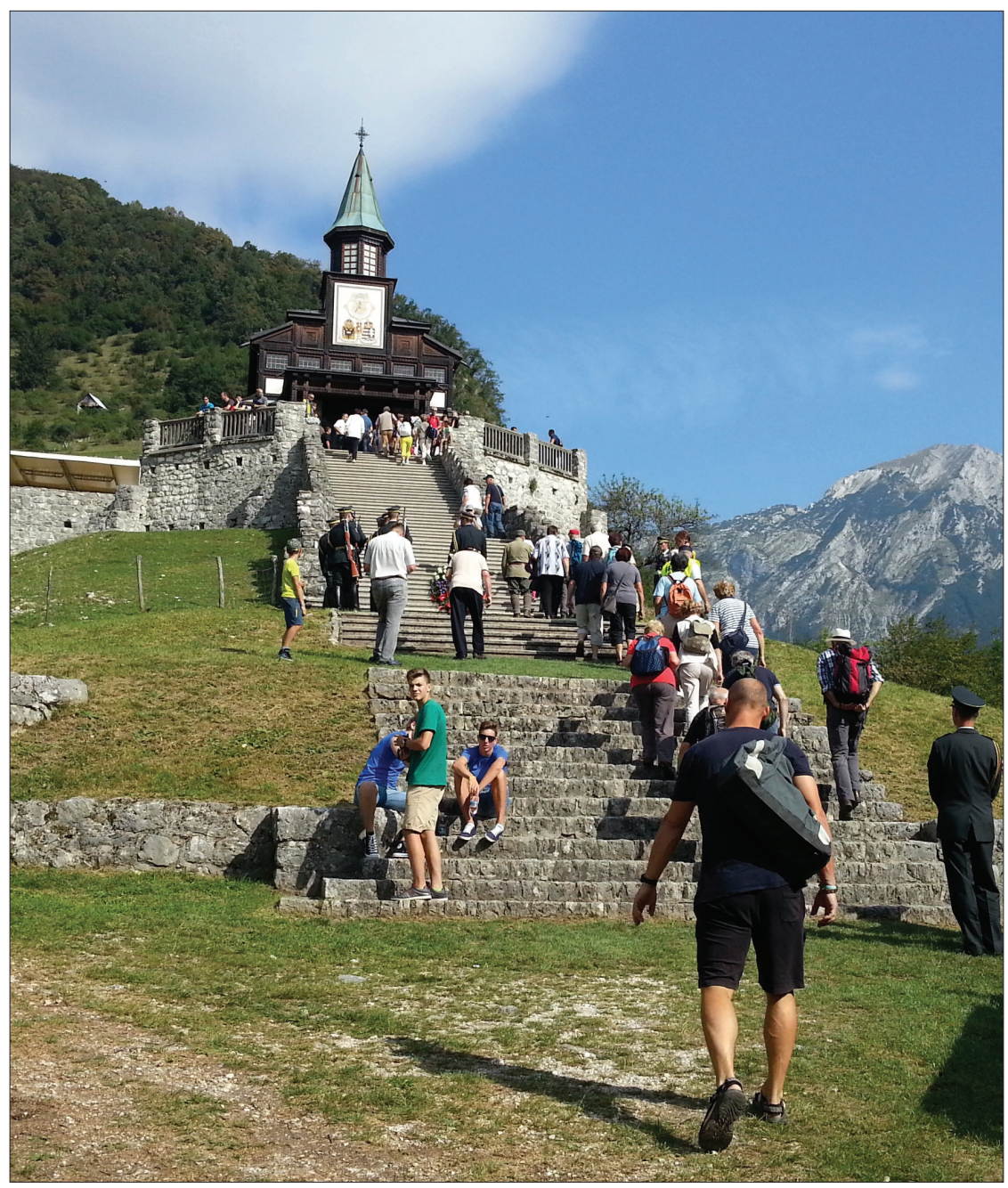

Figure 2. The hundredth anniversary of the church at Javorca, September 2016. Photograph by Miha Kozorog. 




Figure 3. Austrian soldier. Mount Kolovrat: a 2017 reconstruction of the 1917 Battle of Caporetto. Photograph by Jurij Fikfak.

Repič explores relations and connections between the military and postwar landscapes. He discovers how experiences of the landscape and commemorations create a palimpsest of interpretations and heritage productions. Social actors and institutions brought together in the Walk of Peace trail campaign, and individuals have arranged paths, monuments, and memorial places as tourist and hiking destinations. They form narratives that are intensifying national and local political discourses and commemorations. The Isonzo Front 
and its background are a chronotope of simultaneous changes in the process of appropriations of heritage.

In the International Encyclopaedia of the First World War, about fifteen articles are dedicated to the commemoration, including Danilo Šarenac's (2014) article "Commemoration, Cult of the Fallen (South East Europe)". This brief encyclopedia article about rituals in Yugoslavia, Romania, Bulgaria, and Greece does not include Slovenian soldiers. This gap is closed by Tatiana Bajuk Senčar (2018) in her article "From the Hinterland: Commemorating the Centenary of World War I in Bohinj”, using the case of the Bohinj Valley and its surroundings. The hundredth anniversary of the events that took place during the First World War definitely inspired many commemorations across Europe and also stimulated the establishment of a special committee and partly also the staging of certain events (more than four hundred). The author uses the concrete example of the Bohinj Valley in northwestern Slovenia to document and analyze diverse practices of commemoration and heritagization of the First World War. She explores the degree to which tourism is a generator of remembrance, and the extent to which heritage is globalized and serves as an important factor in shaping local identity at the same time (cf. Winter 2009). On the other hand, this has to do with how global trends affect contemporary commemorations and heritagization practices. A key question is also who the social actors are that think it is appropriate or necessary to define the Bohinj Valley and its surroundings as a First World War heritage landscape.

The reinterpretations of the First World War would not be complete without an emphasis on the actors that re-create heritage discourses and use, and sometimes even instrumentalize, the First World War. The first perspective is provided by Miha Kozorog (2018) in his article "Knowledge of Place in Three Popular Music Representations of the First World War", which explores the perception, reception, and production of images of the First World War. It is based on three recent representations in Slovenian popular music: songs by Rodoljubac, Bakalina, and Bratko Bibič. These musicians and musical groups are characterized by the fact that they are connected with the historical region of the Isonzo Front. The author analyzes how the internalization of the knowledge of place and time informed their compositions, identifying four ways of knowing a place, which can be described as absorbing locally shared narratives about a place, engagement with landscapes and the environment, personal memories, and reconsidering a place.

Local collectors form another type of actors, who are analyzed by Boštjan Kravanja (2018) in his article "Learning by Collecting: Amateur Collectors and Their Shifting Positions in the Isonzo Front Heritagization and Tourism Adaptation". Kravanja establishes that there are many local museums and 
private local collections in the area: nearly twenty are open to the public and over a hundred individuals are serious collectors of heritage material. The problem is that these collectors are not registered anywhere, especially by public institutions. The issue gives rise to conflicts between the institutions and collectors: on the one hand, the institutions are ensuring that the material is accessible to the public and, on the other, the collectors are depleting the heritage landscape through their activities.

The Great War did not only claim over fifteen million lives, but has also radically changed the self-image and self-perception of Europeans. Ethnology and folklore studies have dealt with these changes as well as with wartime cultural heritage and especially the heritage of the First World War to a relatively small extent. With the studies conducted as part of the project Cultural Heritage of the First World War in this issue of Folklore: Electronic Journal of Folklore, the journal Traditiones (Jezernik \& Fikfak 2018), and the 15th volume of Ethnologia Europaea Centralis (2018), this situation is at least partly changing.

\section{NOTES}

1 Helmut Kohl described this event in the following video segment: Helmut Kohl: Hand in Hand, available at https://www.youtube.com/watch?v=7Bj6-y0NfZU\&feature=player embedded, last accessed on 5 November 2018.

2 "Italy entered World War I in 1915, declaring war on Austria-Hungary with the express aim of 'redeeming' or reconquering borderland territory claimed by Italy but occupied for decades or even centuries by the Habsburgs" (Gruber 1998).

3 This thematic issue is part of the production of works on cultural heritage and the First World War in the project J6-7173, which is funded by the Slovenian Research Agency and headed by Božidar Jezernik, and further supported by two research programs.

4 See https://www.soca-valley.com/en/attractions/first-world-war/javorca/2018012412091021/ javorca-memorial-church-of-the-holy-spirit/, https://de.wikipedia.org/wiki/ Heiligengeistkirche_Javorca, both last accessed on 5 November 2018.

5 More about the museum in Kobarid see at https://www.kobariski-muzej.si, last accessed on 5 November 2018.

\section{REFERENCES}

Bajuk Senčar, Tatiana 2018. From the Hinterland: Commemorating the Centenary of World War I in Bohinj. Folklore: Electronic Journal of Folklore, Vol. 73, pp. 47-66. https://doi.org/10.7592/FEJF2018.73.bajuk.

Drekonja, Branko \& Potočnik, Aleksander J. 2012. Hemingway's Trail of the Novel A Farewell to Arms. CreateSpace Independent Publishing Platform. 
Ginzburg, Carlo 2012. Threads and Traces: True False Fictive. Berkeley \& Los Angeles, CA: University of California Press.

Gruber, Ruth Ellen 1998. Retracing the 'Great War' on the Isonzo Front. The New York Times, 14 August. Available at https://www.nytimes.com/1998/08/14/style/IHTretracing-the-great-war-on-the-isonzo-front.html, last accessed on 5 November 2018.

Hemingway, Ernest 2014 [1929]. A Farewell to Arms. With a personal foreword by Patrick Hemingway and a new introduction by Sean Hemingway. New York: Scribner.

Ingold, Tim 2000. The Perception of the Environment: Essays on Livelihood, Dwelling and Skill. London \& New York: Routledge. Available at https://leiaarqueologia. files.wordpress.com/2017/08/the-perception-of-the-environment-tim-ingold.pdf, last accessed on 5 November 2018.

Jezernik, Božidar \& Fikfak, Jurij (eds.) 2018. Cultural Heritage of the Great War. Traditiones, Vol. 47, No. 1. DOI: 10.3986/Traditio20184701.

Kozorog, Miha 2012. Dante Alighieri Was Here: Place, Identities, Geographies and Histories in a Small Slovenian Town. Anthropological Journal of European Cultures, Vol. 21, No. 1, pp. 3-21. http://dx.doi.org/10.3167/ajec.2012.210102.

Kozorog, Miha 2018. Knowledge of Place in Three Popular Music Representations of the First World War. Folklore: Electronic Journal of Folklore, Vol. 73, pp. 67-94. https://doi.org/10.7592/FEJF2018.73.kozorog.

Kravanja, Boštjan 2018. Learning by Collecting: Amateur Collectors and Their Shifting Positions in the Isonzo Front Heritagization and Tourism Adaptation. Folklore: Electronic Journal of Folklore, Vol. 73, pp. 95-116. https://doi.org/10.7592/ FEJF2018.73.kravanja.

Repič, Jaka 2018. Memorialization of the First World War in the Landscape of the Julian Alps. Folklore: Electronic Journal of Folklore, Vol. 73, pp. 27-46. https:// doi.org/10.7592/FEJF2018.73.repic.

Šarenac, Danilo 2014. Commemoration, Cult of the Fallen (South East Europe). In: Ute Daniel \& Peter Gatrell \& Oliver Janz \& Heather Jones \& Jennifer Keene \& Alan Kramer \& Bill Nasson (eds.) 1914-1918 Online: International Encyclopedia of the First World War. Berlin: Freie Universität Berlin. DOI: 10.15463/ie1418.10070.

Saunders, Nicolas J. 2001. Matter and Memory in the Landscapes of Conflict: The Western Front 1914-1999. In: Barbara Bender \& Margot Winer (eds.) Contested Landscapes: Movement, Exile and Place. Oxford \& New York: Berg, pp. 37-53.

Schindler, John R. 2001. Isonzo: The Forgotten Sacrifice of the Great War. Westport, CT \& London: Praeger.

Selwyn, Tom 1995. Landscapes of Liberation and Imprisonment: Towards an Anthropology of the Israeli Landscape. In: Eric Hirsch \& Michael O'Hanlon (eds.) The Anthropology of Landscape: Perspectives on Place and Space. Oxford: Oxford University Press, pp. 114-134.

Štepec, Marko 2018. The Experience and Memory of Trenches Near the Soča River. Folklore: Electronic Journal of Folklore, Vol. 73, pp. 19-26. https://doi.org/10.7592/ FEJF2018.73.stepec.

Tilley, Christopher 1994. A Phenomenology of Landscape: Places, Paths and Monuments. Oxford \& Providence: Berg.

Winter, Caroline 2009. Tourism, Social Memory and the Great War. Annals of Tourism Research, Vol. 36, No. 4, pp. 607-626. http://dx.doi.org/10.1016/j. annals.2009.05.002. 


\title{
HISTORICAL INTRODUCTION: THE EXPERIENCE AND MEMORY OF TRENCHES NEAR THE SOČA RIVER
}

\author{
Marko Štepec \\ MA, historian, museum councilor \\ National Museum of Contemporary History, Slovenia \\ e-mail: marko.stepec@guest.arnes.si
}

\begin{abstract}
The First World War brought many changes to everyday life and came as a surprise to many contemporaries. The territory of today's Slovenia mostly belonged to the 3rd Austro-Hungarian Army Corps. More than 160,000 soldiers were mobilized in these recruiting districts. The fact that the labor of at least five people was needed to provide for just one soldier on the frontline sums up how the hinterland was connected with the front. The fatalities among the soldiers were extremely high. During the first five offensives, the positions of the front were basically unchanged despite a large number of casualties. The Italian conquest of Gorica/Gorizia in August 1916 was followed by a new wave of refugees and the retreat of the Austro-Hungarian Army from the Doberdob/ Doberdo Plateau to the new defense line in the Karst region. The atmosphere in the hinterland was affected by a feeling of scarcity and growing discontent. With the successful breakthrough in 1917 (the battle of Caporetto), which shifted the front to the Piave River, the Isonzo Front drew the attention of military strategists and became known internationally. At the end of October 1918, Austria-Hungary collapsed and new states emerged on its territory, among them the State of the Slovenes, Croats, and Serbs. Thus the stories of the soldiers and the memory of the fallen remained within the family circle and local cemeteries, far from national celebrations, out of the collective memory of the new state. Later, the memory of the Second World War and the postwar revolution also completely obscured the memory of the years 1914-1918. A characteristic feature of Slovenia in the period after the Second World War was that the first museum collections were created by private collectors, who collected material remains of the war on the trackless Soča landscape.
\end{abstract}

Keywords: Austro-Hungarian Army, First World War, Isonzo Front, Italian Army, offensive, Soča River, soldiers

The First World War brought many changes to everyday life and came as a surprise to many contemporaries. The war as the pinnacle and breakdown of modernization processes actually changed or destroyed the spiritual and social 
basis of the old world. Its "absurdity was the dust that covered European civilization and placed its 'culture' under a huge question mark" (Kranjc 2001: 18).

The territory of today's Slovenia mostly belonged to the 3rd Austro-Hungarian Army Corps. The population of this area contained only 2 percent of the fifty-two million inhabitants of the country. More than 160,000 soldiers were mobilized in these recruiting districts. Until the end of May 1915, they fought on the Eastern Front against the Russian Army, and many fewer of them on the Balkan Front against Serbia. At the same time, in the distant hinterland of Slovenian regions, a militarization of the economy and a food crisis took place. The well-organized war propaganda skillfully exploited and encouraged patriotic feelings and spread stereotypes about the enemies. Careful management in collecting metal and other raw materials took place, and mottos such as "Gold for Iron", "Grain Days", "Handkerchief Days", and other patriotic charitable collection drives were part of everyday life.

After Italy had joined the war on the side of the Entente, fierce fighting between the Italian and Austro-Hungarian armies took place along the Soča River (Italian: Isonzo) from the end of May 1915 to the end of October 1917. By attacking Austria-Hungary, the Kingdom of Italy fulfilled its obligation under the Treaty of London, concluded between Italy and the Entente Powers in April 1915. The secret part of the treaty promised significant parts of AustroHungarian territory to Italy. The Italian strategic military plan envisaged a breakthrough towards Austria-Hungary toward the Soča River, across the Karst Plateau to the interior of the monarchy, whereby it would deal it a mortal blow and take it out of the war. The Isonzo Front saw eleven Italian offensives and one joint Austro-Hungarian-German offensive. Both sides removed the civilian population from the area of the fighting to various refugee camps.

Heavily loaded carriages creaked, the cattle mooed, and children sobbed while the adults wiped their bloodshot eyes and desperately looked back to the homes they had lost. We exchanged bitter and sympathetic looks and wished each other a safe journey. (Matičič 1922: 31)

After the fighting started along the Soča River, a wide territory behind the frontline belonged to the narrow zone of the military hinterland, in which special martial law was enforced. Behind the frontline there was a well-structured system of hospitals, prison camps, and military workshops. The fact that the labor of at least five people was needed to provide for just one soldier on the frontline sums up how the hinterland was connected with the front, where every day trains, carts, and cableways delivered hundreds of tons of military equipment, ammunition, arms, and replacement battalions of soldiers from all the nations of the monarchy. 


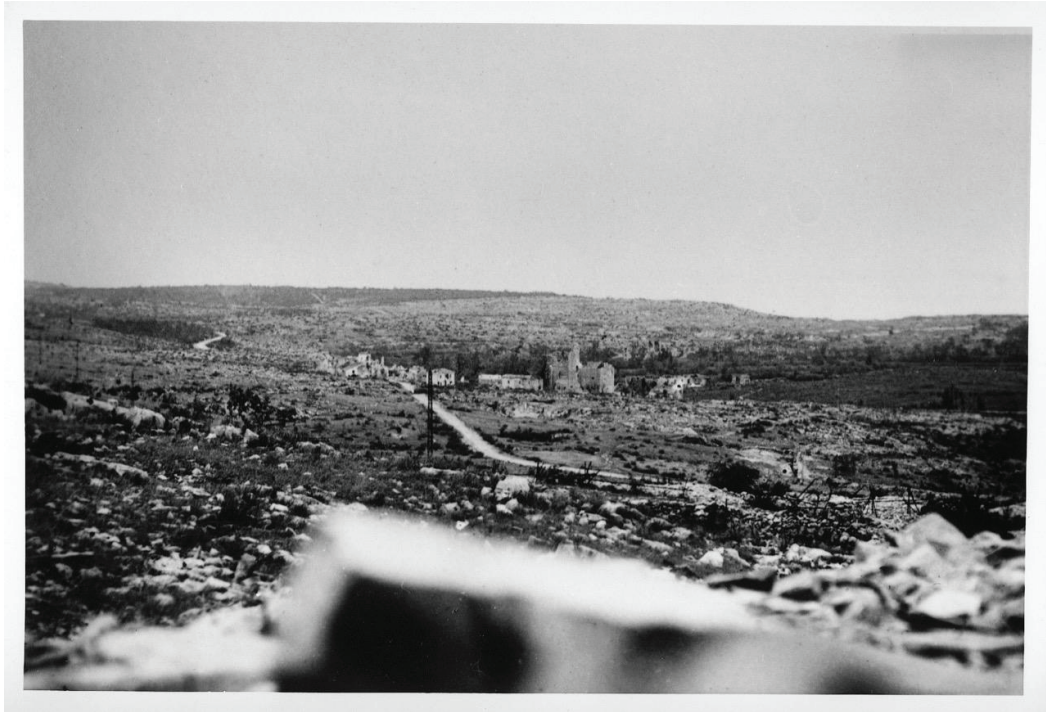

Figure 1. A view of the traces of battles on the Karst battlefield. Courtesy of the National Museum of Contemporary History, Slovenia.

Summing up the experiences of the soldiers that had spent twenty-nine months lingering on and dying on both sides of the frontline, it can be concluded that the living conditions were extremely poor. The soldiers were exhausted, dirty, and ragged, and they suffered from lack of sleep. Unburied corpses remained lying on the battlefield, and rats and lice multiplied (Štepec 2016: 32). Infectious diseases, including cholera and typhoid, spread in the trenches. The defense positions at the beginning were only temporarily fortified and hastily built, and so they offered poor protection from the fierce artillery bombardments. Scant supplies of water and thirst were a huge problem due to the stony Karst terrain with intense sunshine.

Although it was strictly forbidden to use the liquid, which was more like black coffee than water, it did not help. They did not just drink this poison themselves; they also filled their canteens with it and brought it to their comrades. Hunger is bad, but thirst is much worse. Today it disgusts us to think of what we drank then. (Pepernik 2005: 79)

In the northern sector of the battlefield, soldiers faced extremely difficult weather conditions and problems with regular supplies. The offensive operations of the Isonzo Front often started with artillery preparations lasting a few hours or days, and were followed by infantry attacks across no-man's land traversed 
by barbed wire. The defenders tried to stop the attackers with fierce artillery shelling, heavy rifle fire, mortars, and flame-thrower fire. If the attackers succeeded in reaching the enemy's positions, they faced completely insane shellshocked soldiers with their rifles, bayonets, and sharpened shovels. Despite the modern military technology, a hidden barbaric essence of war surfaced at that particular time. "We were no longer people, not even wild beasts, but simply something else without a name. All human feelings were frozen in us; we had lost everything that we had," wrote private Jakob Zemljič (Rihtarič 1999: 16). The fatalities among the soldiers were extremely high, and those that survived were eager to be replaced and removed from the first frontline. Many of them were wounded or suffered from mental illness as a consequence of such a shock. The poet Avgust Fabjančič recalled:

The air pressure threw me aside, but a piece of the shell tore the pocket on my left side, in which I had my notebook of poems. When I came to, I saw that the shell had torn my comrade to pieces, who was from somewhere near Braslovče ... I gathered up the shredded poems, my notebook. Those three days and nights of terror cannot be described, such can only be experienced. And you had to have strong nerves not to go mad. (Štepec 2014a: 53)

Those that survived the battles were disinfected and sent on leave to military places of amusement, hospitals, or to the hinterland only to later return to the battlefields. These procedures took place during all the eleven offensives that are now known as the Isonzo Front. During the first five offensives, the positions of the front were basically unchanged despite the large number of casualties.

Towards morning, the enemy launched an attack on Hill V. By surprise, they succeeded in taking an important fortified position held by soldiers of the 42nd Infantry Regiment. Then a deathly silence occurred. As stretcher bearers, I [Giuseppe Cordano] and Rocchi tried to carry two seriously wounded Bersaglieri and one dead soldier to the first aid station. With that melancholy task, on top of the effort and danger, we thus also have real insight into the pain and tragedy we have fallen into. (Cimprič 2014: 44)

The Italian conquest of Mount Sabotin, which was a crucial defense position, was an important turning point of the Isonzo Front (Macdonald \& Cimprič 2011: 91). The Austro-Hungarian commanders were forced to order a retreat by the army and the evacuation of the rest of the civilians from Gorizia to the left bank of the Soča River. The Italian conquest of Gorizia was followed by a new wave of refugees and the retreat of the Austro-Hungarian Army from the Doberdò Plateau to the new defense line in the Karst region. 
Due to the growing military needs, a lack of labor and a food crisis soon arose and increased to the level of starvation throughout the country. The atmosphere in the hinterland was affected by a feeling of scarcity and growing discontent. In 1917, political demands to reform the monarchy stated in the Vienna parliament and expectations for peace increased in the rear. This new hope for an expected peace was interrupted by the noise of artillery fire in the area between Tolmin and the Adriatic Sea. The new and largest Italian offensive along the Soča River began on August 18, 1917 (Sedmak 2010: 32). Although the Italian Army once again failed to realize its aim, the Austro-Hungarian Army had to draw back its reserve defensive lines on the Banjšice Plateau. More than thirty thousand missing Austro-Hungarian soldiers (along with forty thousand Italian soldiers and ten thousand Austro-Hungarian soldiers dead) and a shortage of reserve units was more than a clear warning to the high command of the Austro-Hungarian Army that they would no longer be able to endure a similar offensive and that something needed to be done.

Thus the arrangements with the German allies started even before the Italian offensive had finished, and they decided that a joint offensive called Waffentreue (Loyalty in Arms) would begin in the Upper Soča Valley. For the needs of the offensive, they had to transport the necessary military equipment, artillery, ammunition, and troops to the Upper Soča Valley, which had a poor communication system. One hundred and twenty military transports passed the Ljubljana railway station every day in October. It is no wonder that the Ljubljana lawyer Fran Milčinski wrote in his diary: "Our own planes above Ljubljana every day, troops and transports along the roads - large wagons pulled by three pairs of horses. A high, dense constant dust lies like fog above the whole of Ljubljana" (Milčinski 2000: 288).

A joint army was formed. It consisted of six German divisions, mostly infantry, and five Austro-Hungarian divisions. They began the attack on October 24, 1917, at 2:05 am, when the order was given to begin with artillery and grenade attacks in a carefully planned sequence (Simić 1996: 195). The attack was especially intense in the area between Mount Rombon and Tolmin. Many grenades were marked with green, blue, and yellow crosses because they were filled with different gases. They had an enormous psychological effect. The efficient and short artillery preparations turned into an offensive attack at 9 am in Bovec. Franc Arnejc, a soldier in the 7th Infantry Regiment, was very emotional and horrified, and he wrote about the first day of the offensive:

This mournful thunder echoes and rebounds terribly from the mountain cliffs. You can't hear your voice, because of the very long persistent cracking. Most of these shells are filled with gas. Death now has a terrible 
harvest here. Our numerous cannons only heap up the human slaughter, there on the Italian side. The whole front is one big flame because of the bursting shells and shrapnel... The Italian battle line is a sad sight: full of dead and wounded lying all around here; the caves in many places are full of corpses because they crammed into them and perished there from poison gas. (Arnejc 1970: 79)

The German 12th division was successfully advancing in the area between Tolmin and Kobarid as well. On the first day of the offensive, the Italian defense line had already been broken through and a great number of Italian soldiers had been captured.

Artilleryman Albin Mlakar wrote in his diary about the first day of the breakthrough:

We froze by the cannons and waited for the weather to improve, but hopelessly... At night, our soldiers fired gas grenades. Some of the shots fell into our trenches and poisoned some soldiers, and they ripped off the arms and legs of a lieutenant, who later died. (Mlakar 1995: 164)

After the successful breakthrough between Tolmin and Kobarid, the frontline moved deep into the interior of Italy across the Piave River. After twenty-nine months of fighting, the weapons fell silent. With the successful breakthrough that shifted the front to the Piave River, the Isonzo Front drew the attention of military strategists and became known internationally. The frontline near the Piave River did not change again until the end of the monarchy. An unsuccessful June offensive merely increased the discontent, and at the end of October 1918 Austria-Hungary collapsed and new states emerged on its territory, among them the State of the Slovenes, Croats and Serbs. At the beginning of November, Austria-Hungary signed an armistice, and the Italian Army marched across the prewar Austro-Hungarian border with Italy.

After the war, families, war veterans, and the church in cooperation with local communities began to erect memorial plaques and monuments to the fallen soldiers. However, they only rarely listened to survivors when they talked about their often traumatic wartime experiences. It seems that everyone just wanted to forget the war as soon as possible. Thus the stories of the soldiers and the memory of the fallen remained within the family circle and local cemeteries, far from national celebrations, out of the collective memory of the new state (Štepec 2014b: 64). In the everyday propaganda of the new state, Austria-Hungary became a more or less hated "prison of nations". Its army, which had lost the war, was considered alien, "not ours", and it was written out of school books. It must be remembered that the soldiers of various nations that made up the new 




Figure 2. Austro-Hungarian military cemetery at Gorjansko. Courtesy of the National Museum of Contemporary History, Slovenia.

state had fought on opposing sides, which had a significant impact on the formation of a common state memory. Even the Isonzo Front, which ran through the Slovenian territory near the Soča River, and units from Slovenian mobilization regions, who fought and died on battlefields from the Karst Plateau to Mount Rombon, did not receive the expected space in school curricula (Svoljšak 1993: 276). Later, the memory of the Second World War and the postwar revolution also completely obscured the memory of the years 1914-1918.

A characteristic feature of Slovenia in the period after the Second World War was that the first museum collections were created by private collectors, who gathered material remains of the war on the trackless Soča landscape. The war was deeply imprinted in the landscape and its traces could be found in the changed appearance of the environment, crisscrossed with kilometers of trenches, military constructions, roads, barbed wire, material remains, weapons, shells, and military equipment. There are also many military cemeteries and monuments from the Adriatic Sea to Mount Rombon that are reminders of the huge numbers of fallen soldiers. The attitude towards the Great War and Isonzo Front heritage in these hundred years has turned from marginalization and oblivion to an important part of collective memory in Slovenia. 


\section{ACKNOWLEDGEMENTS}

This article was written within the framework of the special issue titled Cultural Heritage of the Great War (Traditiones, Vol. 47, No. 1, 2018, edited by Božidar Jezernik and \& Jurij Fikfak).

\section{REFERENCES}

Arnejc, Franc 1970. Od Dnestra do Piave: Spomini iz prve svetoune vojne. [From the Dnester to the Piave River: Memories from First World War.] Klagenfurt: Družba Sv. Mohorja.

Cimprič, Željko 2014. Giuseppe Cordano. In: Štepec, Marko (ed.) We Never Imagined Such a War. Ljubljana: National Museum of Contemporary History, pp. 43-44.

Kranjc, Igor 2001. France Kralj. Ljubljana: Slovenska matica.

Macdonald, John \& Cimprič, Željko 2011. Caporetto and the Isonzo Campaign: The Italian Front 1915-1918. Barnsley, UK: Pen \& Sword Books.

Matičič, Ivan 1922. Na krvavih poljanah. Trpljenje in strahote $z$ bojnih pohodov bivšega slovenskega planinskega polka. [On the Blood-Soaked Plains: Suffering and Horrors of the Battle Marches of the Former Slovene Mountain Regiment.] Ljubljana: Učiteljska tiskarna.

Milčinski, Fran 2000. Dneunik 1914-1920. [Diary 1914-1920.] Ljubljana: Slovenska matica.

Mlakar, Albin 1995. Dneunik 1914-1918. [Diary 1914-1918.] Kobarid: Turistična agencija K.C.K.

Pepernik, Amandus 2005. Doberdob, slovenskih fantov grob. [Doberdob, the Grave of Slovenian Soldiers.] Ljubljana: Karantanija.

Rihtarič, Ivan (ed.) 1999. Jakob Zemljič: Spomini iz svetovne vojske. [Jakob Zemljič: World War II Memories.] Glasilo letnik, Vol. 6, No. 1, pp. 11-18.

Sedmak, Drago 2010. Isonzo (Soča) Front. In: Slovenci in prva svetovna vojna 1914-1918. [Slovenians and the First World War 1914-1918.] Ljubljana: National Museum of Contemporary History, pp. 47-49.

Simić, Marko 1996. Po sledeh soške fronte. [Following the Traces of the Isonzo/Soča Front.] Ljubljana: Mladinska knjiga.

Štepec, Marko 2014a. Avgust Fabjančič. In: Štepec, Marko (ed.) We Never Imagined Such a War. Ljubljana: National Museum of Contemporary History, p. 53.

Štepec, Marko 2014b. Memory. In: Štepec, Marko (ed.) We Never Imagined Such a War. Ljubljana: National Museum of Contemporary History, p. 64.

Štepec, Marko 2016. "Bedna kritja pod planoto tik nad Sočo": v strelskih jarkih soškega bojišča 1915-1917. ["Miserable Covers under the Plateau above the Isonzo": In the Trenches of the Isonzo/Soča Front 1915-1917.] Zgodovina $v$ šoli, Vol. 24, No. 1-2, pp. 29-38. Available at http://sistory.si/11686/38264, last accessed on 13 September 2018.

Svoljšak, Petra 1993. Prva svetovna vojna in Slovenci. [The First World War and the Slovenes.] Zgodovinski časopis, Vol. 47, No. 2, pp. 263-288. Available at http:// www.zgodovinskicasopis.si/_pdf/Digital-archive/ZC_1993_2.pdf, last accessed on 13 September 2018. 


\title{
MEMORIALIZATION OF THE FIRST WORLD WAR IN THE LANDSCAPE OF THE JULIAN ALPS
}

\author{
Jaka Repič \\ Department of Ethnology and Cultural Anthropology \\ Faculty of Arts \\ University of Ljubljana, Slovenia \\ email: jaka.repic@ff.uni-lj.si
}

\begin{abstract}
This article addresses issues of past and ongoing memorialization processes and heritage construction of the First World War, integrated into the landscapes of the Julian Alps in Slovenia. According to Nicholas Saunders, military histories usually consider landscapes to be inert, static, empty, and self-evident backdrops to military action as well as subsequent practices of memorialization. However, many anthropologists, geographers, and archaeologists have noted that landscapes cannot be separated from human experiences, but are part of a world of relationships, memories, and histories.

This article explores connections between the military and post-military landscape and memorialization of the First World War, established through landscape features, experiences of the landscape, and commemorations by institutions that engage in interpretation and heritage production. Various landscape attributes, such as paths, monuments, and memorial places, are being (re)constructed as tourist and hiking destinations, and the narratives attached to these places are integrated into national and local political discourses and commemorations. Drawing on recent anthropological discussions on the perception of landscape, this article focuses on the Isonzo Front and particularly its background as palimpsest of overlapping spatial changes as well as memorialization and appropriations of heritage in the Alpine landscape.
\end{abstract}

Keywords: Alps, First World War, heritage, memorialization, military landscape

\section{INTRODUCTION}

The First World War was a turning point for European society and also globally in many aspects. Scholars from various disciplines have studied the war and its diverse and lasting implications, but scholarly discussions of the war were particularly dominated by studies focusing on history, political science, and the military. Anthropology, however, has until recently had relatively little 
to say about the First World War. However, as Nicholas Saunders points out, there are some important aspects to be addressed through the anthropological perspective.

The First World War remains ambiguously 'recent' in European imagination - hovering on the boundary between 'living' oral history, military history, museology, and issues of tourism and cultural heritage. ... Anthropologically informed it [research] offers, at the very least, the opportunity to investigate: a) a conflict hitherto known mainly from historical sources, $b$ ) the reconstitution of post-war landscapes, and c) the evolution of commemorative materialities, both large and small (i.e. large monument to small personal souvenir). (Saunders 2013: 20)

This article is part of the research project Heritage of the First World War: Representations and Reinterpretation (see Jezernik \& Fikfak 2018). Theoretically it is based on recent archaeological, geographical, and, particularly, anthropological literature on the environment and landscape, and empirically on historical and ethnographic research in the Bohinj region in Slovenia. It examines the impact of the First World War on landscapes along the Isonzo Front and its hinterlands, particularly in the Bohinj region in Slovenia. It addresses war and postwar landscapes as a medium of memorialization practices, heritage production, as well as locality and identity formation. Hence, it examines landscape as palimpsests of diverse environmental practices and materialities imbued with meanings and memories related to the First World War. Moreover, it also addresses connections between landscape, memories, and identification processes, established through commemoration and heritage production, or personal experiences and perceptions of the environment. Various environmental attributes that were created and integrated into the landscape during and after the First World War - such as paths, fortresses, dugout trenches and caverns, graveyards, monuments, and remains of weapons, and spent and unexploded ammunition - are today still being (re)constructed and reimagined as memorial places, museum artifacts, thematic trails, and tourist and hiking paths. Some of these attributes are also reconstructed as historically defining places for particular localities, with local, institutional, and political narratives referring to memories of war (Bajuk Senčar 2018; Kozorog 2018; Kravanja 2018). These attributes are continuously appropriated by local and national heritage institutions and are constitutive to the landscape of the First World War in the Alps in Slovenia and Italy.

The article starts by presenting various approaches related to landscape studies and highlights the concept of war and military landscapes. It then describes the landscape changes due to military technology and warfare on the 
front and in the Bohinj region as the supply hinterland. Landscape changes include topographical changes that occurred as direct involvement of the military technology and combat on the front and in the hinterland, such as new railways, deforestation, mountain paths, cableways, and military barracks. It also includes changes in the social, economic, and political landscape of the region altered due to war, new industries, and particularly the large number of local people drafted into the armies, and thousands of soldiers from the AustroHungarian Empire coming, leaving, and residing in the area during the war.

Finally, the article examines postwar reconstitution of the landscape and memorialization of the First World War and the production of war heritage in the Bohinj and Isonzo Front regions in the Slovenian Alps. Postwar landscapes continued to change from military landscapes into landscapes of memories and heritage. Graveyards and monuments were constructed, and places previously occupied by the military were destroyed, abandoned, left to decay, or turned into places of memorial and commemorative tourism - and recently into institutional heritage production. The First World War architecturally, technologically, and even morphologically altered and marked the landscapes along the Isonzo Front and its hinterland, and environmental features such as graveyards, monuments, or mountain paths still reconnect people's spatial experiences with memories of war and postwar landscape reconstitution.

\section{ADDRESSING WAR AND MILITARY LANDSCAPES}

The landscape is far from a novel concept in anthropology, archaeology, or geography. Christopher Tilley observed that scholars have had a long interest in the relationships between people and the landscape, but that usually this relationship was conceived rather narrowly as an "environmental milieu", and focused on functional and supposedly adaptive parameters, with matters such as population levels, resource "ceiling", and environmental constraints. In this naturalist or ecological view, the landscape was seen as something inert, a neutral backdrop to activity and a means for material production. Recent anthropological, geographical, and archaeological literature usually addresses the landscape from two dominant perspectives, often labeled either as phenomenological or structural approaches. Phenomenological approaches try to understand people's experiences of the environment, whereas structural approaches "seek to unearth how landscape and the environment have been shaped by political, social, economic and historical forces" (Árnason 2010: 80). Structural approaches focus on political, social, cultural, and economic forces that historically shape or change landscapes and environments, but fail to 
explain how these forces shape daily experience of and in these environments. Quite contrarily, phenomenological approaches explore the ways in which people experience and understand the world, starting from direct experiences of, and engagement with, the environment (e.g. Ingold 1993; Tilley 1994; cf. Ingold \& Vergunst 2008).

Denis Cosgrove and Stephen Daniels posit that the concept of landscape is highly ideological (Cosgrove \& Daniels 1988; see also Cosgrove 1984). In their book titled The Iconography of Landscape, which was highly influential for further discussions on landscape, they write: "A landscape is a cultural image, a pictorial way of representing, structuring or symbolizing surroundings" (Daniels \& Cosgrove 1988: 1). According to them, landscape is not an environment but a literary, artistic, or political symbolization and representation of the environment. Cosgrove writes that "the idea of landscape came to denote the artistic and literary representation of the visible world, the scenery... viewed by a spectator" (1984: 9). Similarly, Tim Cresswell writes: "We do not live in landscapes - we look at them" (2004: 11). For Cosgrove, landscape is a way of seeing, a cultural image with pictorial, literary or material representations on the ground, which are created and read. "Representations of landscape have the potential to both obscure and articulate lived experience" (Tilley 1994: 25). In this sense, landscape representations of memories and heritage are highly complex, often even contested, because they are open to social constructions and political reinterpretations.

However, it is important to note that some scholars disputed such an approach because it implies inherent distinctions and separateness between external reality and human perception and conceptualization of it. Tim Ingold has rejected the division between the "inner and outer world - respectively of mind and matter, meaning and substance", and instead proposed focusing on the dwelling perspective: "The landscape is the world as it is known to those who dwell therein, who inhabit its places and journey along the paths connecting them" (Ingold 1993: 156; cf. Lund \& Benediktsson 2010).

Christopher Tilley also rejects the notion of landscape being merely a form of mental representation and cognition, and points to the interplay between materialities and perception: "The locales in a landscape may be natural features such as bays or inlets on a coastline or high points, or humanly created places such as monuments or settlements" (Tilley 1994: 25). Moreover, many scholars stress the processual quality of the landscape and address its temporality and changeability (cf. Bender 1993, 2001a, 2001b, 2002; Tilley 1994, 2012; Hirsch 1995; Massey 2006). The landscape they posit is in a process of morphological, archaeological, and conceptual changes, a "pattern of activities 'collapsed' into an array of features" (Ingold 1993: 166). Human activities are not merely imprinted 
onto the landscape, they are continuously incorporated into it: "Landscapes ... are part of the world of movement, relationships, memories and histories" (Bender 2001b: 76; cf. Feld \& Basso 1996; Bender \& Winer 2001). Hence, experiences of contemporary inhabitants are always grounded in a historically modified and modifying environment. Ingold has pointed out that people and the environment are mutually constitutive and change-inducing components of the same world: "the landscape is never complete: neither 'built' nor 'unbuilt,' it is perpetually under construction. ... The forms of the landscape are not preprepared for people to live in - not by nature nor by human hands - for it is in the very process of dwelling that these forms are constituted" (Ingold 2000: 193).

The contemporary world was thoroughly shaped through wars and military technology. Particularly experiences and memories of the First World War have deeply influenced the formation of European societies, heritage politics, and practices of memorialization. Nicholas Saunders addressed war landscapes and particularly the Western Front as a symbolic landscape for our time: "human experiences of the Western Front landscapes between 1914 and 1918 were deeply formative ... (and) impressed vivid imagery onto individual and collective memories" (Saunders 2001a: 37).

War and military landscapes are socially and historically constructed landscapes comprised of physical places with an array of materialities such as natural features, buildings, paths, roads, infrastructures, monuments, memorial places, and places of commemorative events. Military actions were incorporated into the landscape as much as landscape features affected the practices and experiences of mountain warfare (cf. Keller 2009). Memorialization of the First World War has been an ongoing process of spatial incorporation of war and other military activities as well as memorial, commemorative, and heritage-making practices into the landscape by diverse local, national, and international actors and institutions.

Rachel Woodward broadly defines military landscapes as "landscapes which reflect in their constitution and expression the imprint of military activities" (2014: 41). I broaden this view by encompassing an entire palimpsest of mundane and military materialities and activities as well as postwar reconstitution and incorporation of the remnants and memorials of the war. War memorials, monuments, architectural and technological remains, and the spatial practices and politics of memorialization profoundly change the perception and imagination of the landscapes, local and national histories, and heritage. The Isonzo Front and its geographical backgrounds have been outfitted with service paths, military remnants, graveyards, and monuments, as well as with numerous accounts and narratives of battles, human misery, and achievements. 
War and military landscape received relatively little attention in anthropology, unlike in military studies, history, geography, and partly also archaeology. Traditionally, military studies examined the landscape through the utility of the environment in military strategies. Military fronts have mainly been researched in terms of military history - as a "place of stasis and attrition, human misery, suffering, death and eventual victory" (Saunders 2001a: 37). Usually such an approach sees "landscape as inert - an empty backdrop to military action" (ibid.). However, Woodward (2014) lists several studies in which war and the military landscape were addressed in terms of identity construction, social memories, and heritage production. For example, Ross Wilson (2011) shows how naming of places and landscape features among the British soldiers on the Western Front made possible a sense of place and construction of their military identities. After the war, the military landscape was turned into a landscape of mourning, commemorations, tourism, and heritage production (see Morris 1997; Iles 2003; Winter 1998 [1995], 2006; Saunders 2001b, 2002). For example, David W. Lloyd (1998) describes the development of postwar tourism and pilgrimage to military sites, and Snezhana Dimitrova (2005) addresses the commemorations, memorial sites, and monuments of the First World War Bulgarian soldiers as landscape of memories and forgetting, which also played a role in national identity construction.

Saunders proposed exploring the First World War fronts not just as a "series of battlefields, but as a palimpsest of overlapping, multi-vocal landscapes" (Saunders 2001a: 37). In line with recent discussions of landscape in anthropology, which stress its processual quality, in which human actions are integrated into the landscape not as layers to be uncovered by archaeological studies, but as always in a process of change, and subjected to constant reinterpretations and representations, I address war and military landscapes as ongoing processes, still affecting lives, memories, politics, and heritage production a century later.

\section{THE MILITARY LANDSCAPE IN BOHINJ AND THE WIDER ISONZO FRONT}

During the First World War the Bohinj region was an important supply hinterland for parts of the Isonzo Front. Bohinj is a basin in the Upper Carniola region in northwestern Slovenia; it is oriented east-west and bounded to the west by the Julian Alps and periglacial Lake Bohinj. From the lake basin two inhabited valleys, the Upper Bohinj Valley and Lower Bohinj Valley, open towards the east. The lake is fed by the Savica River with Savica Falls as the spring. From the lake on the east end, the Bohinjka River flows along the lower valley, the 
Nomenj Basin, and through a narrow canyon almost closing the valley to the east. Lake Bohinj lies at an elevation of 526 meters, and the highest mountains surrounding it are well over 2,000 meters high.

At the start of the First World War, Bohinj's population of less than five thousand people was dispersed among several small villages and the industrial and administrative town of Bohinjska Bistrica. Historically, the economy of the valley predominantly relied on iron mining, forestry, and agriculture. The most important segment of agriculture was cattle farming, especially for cheese and other diary production, and, to a lesser extent, meat and leather products. The valley is surrounded by medium- and high-elevation pastures where transhumant grazing was practiced (see Repič 2014). Hence before the war the mountainous landscape was already traversed by various paths leading to forests, pastures, and hunting lands. On some of the mountain plateaus, archaeological finds show temporary settlements as early as the seventh to third centuries BC. In the Middle Ages, the people of Bohinj started using the mountain plateaus, located between a few hours and a full day of walking from the valley, for transhumant summer pasturing. Before the war most of these mountain plateaus were high-elevation pastures surrounded by forests and high mountains. On some of them there were settlements with wooden buildings and cattle enclosures for temporary cattle herding and cheese production during the summer months.

Starting in the late nineteenth century, Bohinj also developed tourism infrastructure and services, initially through mountain guiding and hiking. "Mountain guides discovered and built new mountain paths and participated in the construction of mountain lodges" (Bajuk Senčar 2005: 76). Since then, tourism became a steadily growing economic segment that, despite coming to a halt during the First World War, again proliferated after the war, also with memorial and commemoration tourism.

The local population's relations with the environment changed with the start of the First World War, which had a lasting impact on the society, economy, and landscape. The military front in the mountains above Bohinj was established in spring 1915, but the war already demanded heavy provisions from the civil population, such as labor and agricultural produce. In addition, men that were not employed in critical infrastructure were drafted into the Austrian army to serve on the Russian front. Bohinj was not excluded from this. In July 1914, when military mobilization started, about two hundred men were drafted from Bohinj into the Austrian army to serve on the Eastern Front.

On May 23, 1915, Italy declared war on Austria-Hungary and a six-hundredkilometer Austrian-Italian military front was established, stretching from the Stelvio Pass close to the borders between Austria, Switzerland, and Italy, 
extending across Trentino and South Tirol, the Dolomites, the Carnic and Julian Alps, and all the way to the Adriatic coast along the Isonzo Valley. The Isonzo Front was opened with the Italian offensive in June 1915, which aimed to capture the Isonzo Valley and Karst Plateau, and cross the mountain ranges. It stretched for approximately ninety kilometers from Mount Rombon as the northern extreme and along the Isonzo Valley to the Isonzo estuary in the Adriatic. From the beginning, the Italian army failed to penetrate the AustrianHungarian defenses even though the Italian army initially greatly outnumbered the Austrian-Hungarian army. Hence the Isonzo Front was mostly static for the next two and a half years until October 1917, when, in the Twelfth Battle of the Isonzo or the Battle of Caporetto, the Austrian and German armies managed to break into the Italian defenses and pushed the Italian army into the Venetian lowlands. However, for almost two and a half years the front was fortified on the mountain ranges, making good defensive positions possible on both sides. That meant that the mountain warfare, as violent as it was, was also very static, not unlike the Western Front, because the soldiers of both armies were fortified in the high mountains and shielded in excavated caverns and stone fortifications. This static warfare nevertheless resulted in high numbers of dead and wounded, with estimates between seven hundred thousand and over a million casualties on the Isonzo Front alone.

The military division of the Isonzo Front was organized between the frontline and the hinterland, which was also heavily impacted due to the mountainous warfare. The Bohinj region was a supply hinterland to parts of the Isonzo Front, particularly to the Mount Krn battlefields in the high mountains above the Isonzo Valley. As a hinterland to the front, Bohinj played an important role in military supply. The main infrastructure such as the railroad was heavily protected and new infrastructure was developed for military purposes. The military presence and governance were a ubiquitous fact of life in the valley during the war. Movement of the local population in Bohinj was restricted, and residents had to provide travel documents when entering or leaving the region. On the other hand, thousands of military personnel traveled through the valley or stayed there before they moved to the mountain front. The Bohinj Valley on the one hand lost many young men that were drafted into the army, but on the other hand thousands of soldiers of the Austrian army were settled in military camps, hotels, and even with locals. The army had military training camps next to the settlements and also brought Russian prisoners from the Eastern Front. They were settled in prison camps in Ukanc to work at military and infrastructure projects.

The locals had to provide the army with provisions, but some locals were also employed to work for the military; for example, on the narrow-gauge railway. 
Others worked in industries that thrived because of military demands, such as dairy and cheese production, mining, and forestry, or they worked in shops or hotels. A local starting point for the military supply chain was the town of Bohinjska Bistrica. The railroad to Bohinj and the tunnel from Bohinjska Bistrica to Tolmin in the Isonzo Valley was already built in 1906 as the main rail line between Prague and Trieste on the Adriatic Sea, passing through Villach, Jesenice, Bohinj, Tolmin, and Gorica/Gorizia. During the war the Bohinj railway was the main supply line of the Austrian army at the Mount Krn battlefield, used to transport military material, clothes, weapons, food, and building material to Bohinj and from there to the mountain frontline. Large warehouses were built in Bohinjska Bistrica, which were later transformed into a timber factory. From there, a road and later a narrow-gauge railroad were built, leading towards Ukanc just below the Komna Plateau. Cargo was transported there and to the mountains, at first on foot and with horse-drawn carriages, and later on most of the cargo was transported by rail and cableways. The local population and horses were used for help with the transport. In the fall of 1915, the Austrian army organized the building of the narrow-gauge railway to Ukanc and the base of the mountain (see Budkovič 1999: 35-45). Initially, this railway relied on horses that pulled carriages. In 1917, with the increasing demands for transportation of food, fuel, ammunition, weapons, mail, sanitation material, clothing, and building material to the front, the Austrian army built a power plant on the Savica River to power cargo trains on this railway. From Ukanc, the cargo was transported to the mountains on newly built mule tracks and by means of cargo cableways.

Ukanc, previously a pastureland west of the lake and close to the base of the mountains, was turned into a military site. Russian prisoners were settled in Ukanc to perform most of the infrastructure work, especially building paths and roads and digging trenches. Previous pasturelands in Ukanc were transformed into military camps, storage places, and training sites. From Ukanc, mountain paths and mule tracks as well as cableways were built leading all the way to the Komna Plateau at around 1,500 meters in elevation. At Komna, a highland pasture, the Austrian army built a camp for soldiers and officers with a military field hospital, officers' quarters, barracks for soldiers, warehouses, cargo cableways, a chapel, and a graveyard. From Komna the military built mountain paths and cableways that led all the way across the Bogatin Pass and toward Mount Krn to the frontlines. The largest cableway started in Ukanc and ascended to Komna, over the Bogatin Pass to the Peski Ridge, and down to the Tolmin Valley (the military system of cableways was described by Budkovič 1999: 51-77). Just before the Bogatin Pass, at an elevation of almost two thousand meters, another military camp was built, and reserve defensive positions were fortified in case the Italian army broke through the Mount Krn front. 
Before the war, there was practically no substantial infrastructure apart from pasture shelters and mountain paths. New paths and mule tracks, cableways, military camps, a cemetery, and dumping grounds thus profoundly changed the mountainous landscape. There was daily traffic of soldiers and workers (often Russian prisoners) climbing or descending the mountains along these paths and transporting all kinds of materials, weapons, ammunition, and bodies of dead soldiers. Altogether over two hundred kilometers of cableways were built with the capacity to transport several hundred tons of equipment and supply per day.

Similar large-scale infrastructure work was carried out above Kranjska Gora, north of the Bohinj region, where a cableway led to the Vršič Pass (1,611 m) and descended to the Trenta Valley of the Upper Isonzo Valley. In addition, mostly through the work of Russian prisoners, a mountain supply road was built, leading from Kranjska Gora to the Vršič Pass and descending to the source of the Isonzo River along the Trenta Valley. This is still the main connecting road between Upper Carniola and the Upper Isonzo Valley. During its construction, workers were exposed to harsh winter conditions and avalanches. On March 8, 1916, a large avalanche destroyed one of the work camps and killed around two to three hundred Russian prisoners working on the road, and up to eighty Austrian guards. This was the deadliest avalanche in Slovenia to date. Later in the same year, the Russian prisoners built a memorial chapel (the Russian Chapel) next to the road, which has remained a site of changing commemoration practices and even political rituals at the national level. However, the Russian prisoners that worked on the road did not only die in the avalanche. Most of them, an estimated eight to ten thousand, died due to severe conditions, diseases, cold, and exhaustion.

The landscapes of the Bohinj region in Slovenia and other regions of the Isonzo Front were shaped by military involvement and post-military reconstitution into the landscape of memory and heritage. The First World War frontlines were predominantly static ones, but the war nevertheless utterly changed the landscapes of the front and its hinterland due to the technological, engineering, architectural, and social impact of the military and its supply and production chain. Frontlines were inscribed into the environment with trenches, fortresses, caverns, blasted ground, leftover unexploded ordnance, remnants of military equipment, and human remains. The hinterland was also changed into an industrial landscape of supply roads, railways, factories, and military and prison camps. In contrast to large parts of the Western Front that occupied a previously mostly inhabited or cultivated environment, and changed the idyllic rural landscape into a wasteland of "endless craters, barbed wire (and) devastated buildings" (Saunders 2001a: 38), the Alpine frontlines were set up in an uninhabited mountainous environment with a mountain landscape. 


\section{POSTWAR MEMORIAL LANDSCAPES AND HERITAGE PRODUCTION}

The social and spatial devastation at the end of the war, in 1918, was beyond comparison with anything in history. The dead, missing, and wounded were counted in the millions, and many of the survivors were ill, crippled, or mentally affected. The landscapes of the front and its hinterland were also devastated or changed by industrialization and infrastructure. Trees were cut on a massive scale and used for construction timber and firewood at the camps and on the front. Roads, a railroad, a power plant, mountain paths, and cargo cableways were constructed as entire regions were militarized. At the front, land and life were destroyed, and the landscape acquired new meanings through military actions and human experiences of war. In the Alps, the soldiers on the front took up positions in caverns, trenches, and fortresses. They were not only targeted by enemy bombs, but also endangered by the harsh mountain environment, cold temperatures, and deadly avalanches in the winter.

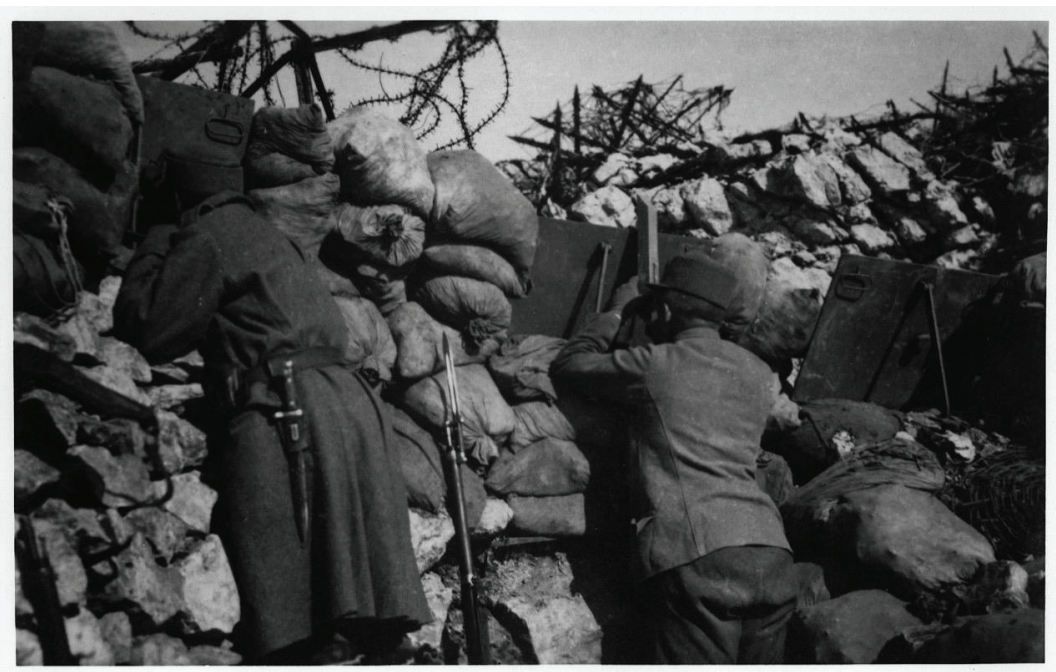

Figure 1. Austro-Hungarian positions on Mount Batognica - the first frontline. Courtesy of the National Museum of Contemporary History, Slovenia. 




Figure 2. Krn Mountains, Batognica - resting in a trench on the first frontline; the soldiers' firearms and cold weapons are well discerned in the photograph. Courtesy of the National Museum of Contemporary History, Slovenia.

The immediate landscape in which they lived, fought, and often died, utterly characterized their perceptions of the landscape, experiences of war, and memories and commemoration practices after the war. During the war, military landscapes were represented to the public through photographs, films, drawings, and paintings, but they were also portrayed in newspaper reports, personal diaries, memoirs, novels, war poetry, and art. "The human cost of these new landscapes was described day by day ... in memoirs and regimental war diaries" (Saunders 2002, 2003). In the narratives and art, war landscapes were often portrayed as something otherworldly, barren, desolate, lifeless, and poignant.

After the war, the landscape stood as a silent reminder to the memories of the war. It was filled with remnants of industrialized warfare, ranging from trenches, dugouts, battlefield markings, monuments, spent shells, shrapnel, and unexploded ordnance to body parts. The abandoned fronts were composed of tombs for the missing, graveyards of unknown soldiers, and places for returning and pilgrimage. In France, some areas were so devastated they were considered too dangerous to reoccupy. There were also tensions between farmers that wished to return to their land and those that wanted the devastated land and the ruins to remain as a memorial site to the war and the dead (see Saunders 2001a: 41-42). War-torn landscapes were seen as memorial places per se. 
Figure 3. Soldiers wearing white covers to increase camouflage in snow in the high mountains of the Soča battlefield. Courtesy of the National Museum of Contemporary History, Slovenia.

Along the Isonzo Front, battles took place in the mountains, but the

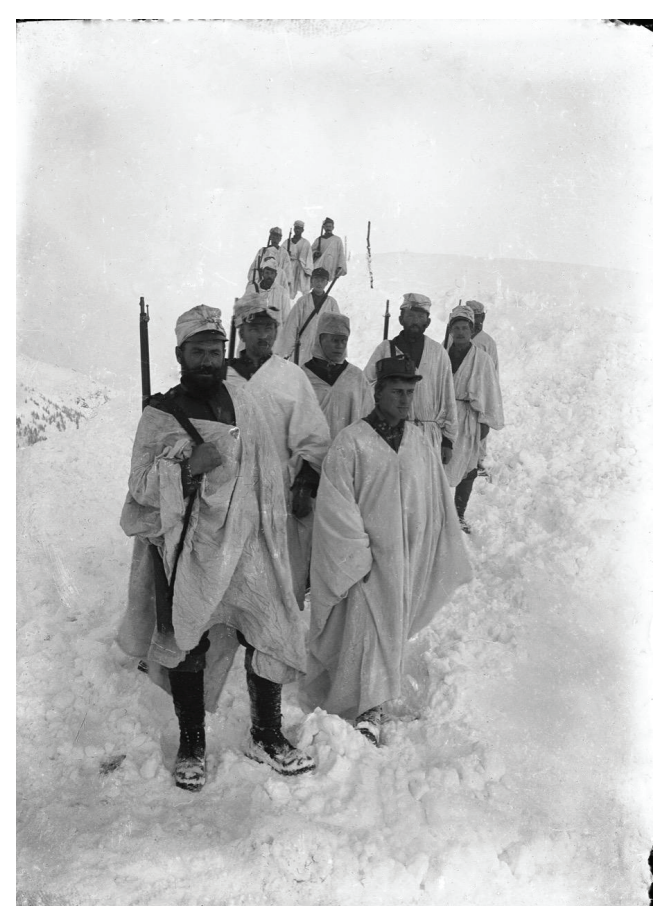
locals nevertheless collected a great amount of military artifacts and eventually engaged in representations and reinterpretations of the war through local museums and military collections (see Kravanja 2018).

Military constructions were dismantled or abandoned, or their function was changed: buildings were turned into mountain lodges, monuments were built, and open-air museums were established. Some of the infrastructure, such as paths and cableways, was used for new purposes after the war. The Bohinj narrow-gauge railway was used for two more years after the war for local transport and even transporting tourists before it was dismantled. Specific places such as graveyards and caverns were turned into memorial or heritage sites or tourism infrastructure.

Part of the cableways between Savica Falls and the Komna Plateau was reconstructed and is still operational. Some of the houses on the Komna Plateau were razed to the ground and some are still preserved as mountain cottages. On the Komna Plateau, the wartime cemetery was later dug up, and the bones of the fallen soldiers were collected and reinterred in a pyramid-shaped memorial ossuary. Pathways and mountain roads for transporting artillery and soldiers were later used as hiking paths. During the interwar period, these landscapes became places of returning and reconstruction of broken houses and lives, or places of pilgrimage that survivors returned to or relatives of the victims visited. 


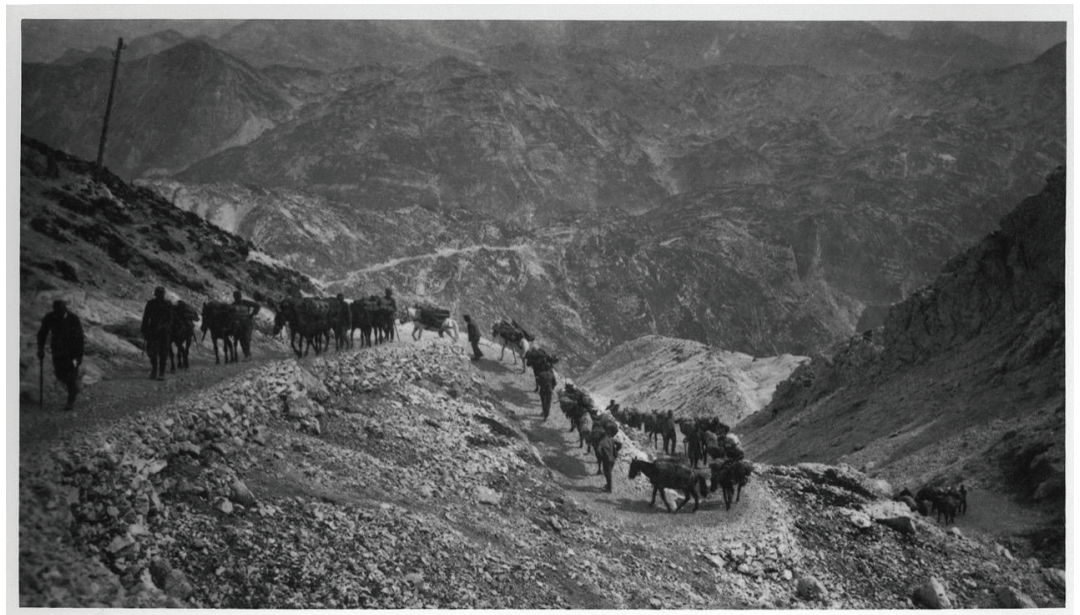

Figure 4. Austro-Hungarian soldiers on their way to the frontline in the Krn Mountains: a view from Peski towards Lemež and Vogel. Courtesy of the National Museum of Contemporary History, Slovenia.

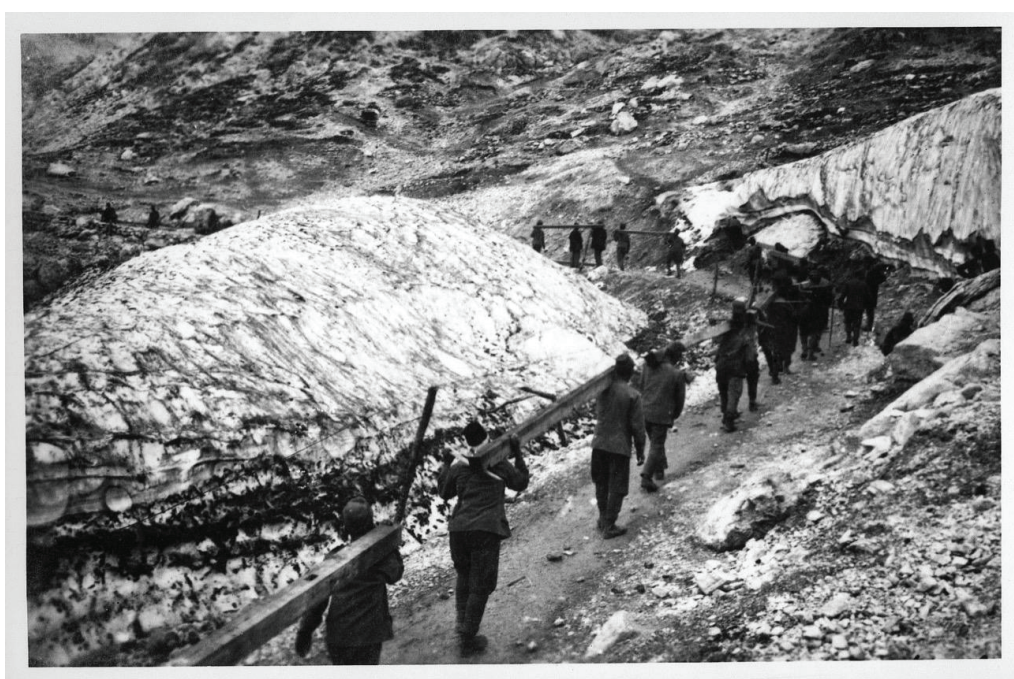

Figure 5. Austro-Hungarian soldiers transporting building materials on their way to Planina na Kraju, in the Krn Mountains above Bohinj. Courtesy of the National Museum of Contemporary History, Slovenia. 


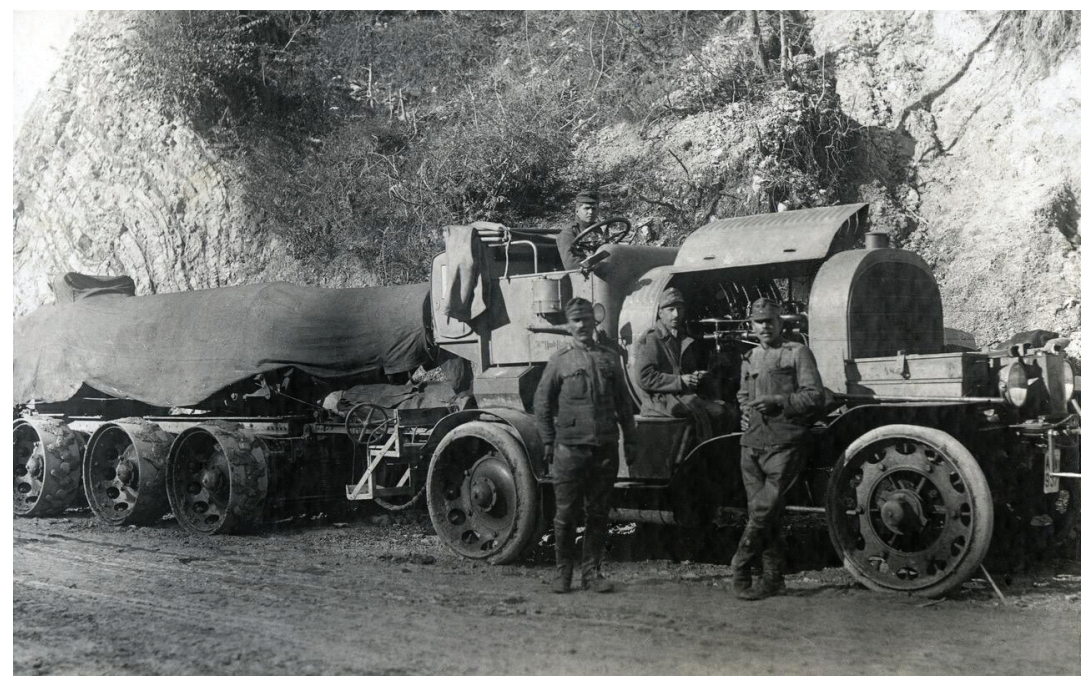

Figure 6. Many new soldiers, plenty of equipment and arms had to be transported to Posočje for the needs of the joint Austro-Hungarian and German offensive. Transportation of the Austro-Hungarian $38 \mathrm{~cm}$ mortar on the road towards Podbrdo. Courtesy of the National Museum of Contemporary History, Slovenia.

With time and the Second World War, these landscapes were largely forgotten. Several monuments were erected, but many memorial places, such as graveyards, mountain fortresses, or caverns, were only much later transformed into tourist destinations, sites for archaeological research, or collections of military remains. Politics and practices of remembering and forgetting are seen in the changing landscape: battlefield remains were removed, reconstructed, or moved into institutions such as local museums. Saunders writes (2001a: 45) that the rediscovery and remembrance of the First World War in France started with the fiftieth anniversary of the war.

In the Isonzo Front region, the social memory of the First World War was diminished because of the importance of the Second World War for communist Yugoslavia (Luthar 2011). Most visible are numerous war graveyards, scattered along the Isonzo Front. Mostly in the Austrian part memorial graveyards were built, whereas on the Italian side ossuaries are common. Unlike in France, in the Kingdom of the Serbs, Croats, and Slovenes dead soldiers were not overly commemorated because it was difficult to glorify the military defeat. In Bohinj, several monuments and memorials dedicated to the victims of the First World War were created, mainly because of the local victims. There are also several 
memorial sites, such as graveyards in Ukanc and Bohinjska Bistrica, and the aforementioned cemetery on the Komna Plateau, which was removed a few years after the war. Larger projects of the First World War heritage production only started in the 1990s and proliferated with Slovenian accession to the European Union. In the recent past, there have been ongoing processes of heritage production (see Fikfak \& Bajuk Senčar 2015; Bajuk Senčar 2018). Monuments and memorial places became places of tourism, commemoration, and political contestation. "The increase in tourists began to change both the physical and cultural landscapes in terms of re-presenting First World War sites to a late twentieth-century audience" (Saunders 2001a: 45).

The Isonzo Front has been turned into a symbolic landscape of memories and heritage. In 1990 the Kobarid Museum was established to represent heritage of the First World War along with the Isonzo Front. In 2000 the Slovenian government established the Walk of Peace in the Soča Region Foundation to preserve the heritage of the Isonzo Front. This turned into an international project, which aims to change the once war-torn places into places of memories. It is a remembrance route crossing the Slovenian-Italian border that connects sites of cultural heritage (graveyards, chapels, forts, outdoor museums, etc.) of the First World War between the Alps and the Adriatic. As an example of the heritage production, the Walk of Peace was submitted to UNESCO's Tentative Lists in 2016 with the following assertion:

The First World War has left a permanent imprint on that territory. Until today, abundant material heritage has been preserved along the former front line: fortresses, trenches, observation posts, transportation ways, cabins, natural and man-made caves, military cemeteries, charnel houses, chapels, monuments and memorials.

Over a span of a hundred years the remembrance of the "years of horror" has changed its perspective from the military to commemorative and peace-fostering collective and transnational remembrance. (UNESCO Tentative Lists)

In Bohinj there were also some local incentives to connect Bohinj to the First World War heritage as the hinterland to the Isonzo Front. These include memorial sites, museum exhibitions on the war, and memorial tourism. In 2007 a thematic trail, Supply Hinterland for the Krn Battlefield, was established as a memorial hiking route along the remnants of the war in the valley and in the mountains. In this sense, ongoing heritage making, memorialization of the war, commemoration events, and tourism are still transforming the landscape of war and memory. 


\section{CONCLUSION}

This article addresses how the landscape of the Isonzo Front and the Julian Alps in Slovenia was changed during and after the First World War, and explores how ongoing memorialization and heritage construction of the war is integrated into the landscapes of the front and its hinterland, particularly in the Bohinj region. The landscape of the wider Isonzo Front and its hinterland was radically transformed during the war, but also continued to change after the war. Some of its new features were disassembled or left to decay, some were reused in different contexts, and some remained either as hidden testaments or as evident places of memory and commemorations.

The wartime and postwar landscape does not merely consist of a set of historical layers dating back to the war and various postwar human activities and natural decay or overgrowth. Instead it is constantly changing and integrates diverse materialities ranging from various natural and architectural formations, paths, and other spatial features to imaginaries of places, all of which are maintained in narratives and daily or memorial practices in this particular environment. In this sense, one can speak of the array of diverse environmental attributes, both natural and manmade in their formation, which were created and integrated into the landscape during and after the First World War. Today, these materialities contribute to possible memorialization and heritage construction. Nicholas Saunders writes: "Often unbearably poignant, areas of the Isonzo in northeast Italy, the Ypres Salient in Belgium, and the Somme and Verdun in France, became prime examples of the social construction of landscape ..., which have implicated the lives of a succession of people since 1914" (Saunders 2004: 7).

Monuments, mountain paths, fortresses, trenches, caverns, railroads, armor, weapons, unexploded ordnance, graveyards, monuments, letters, diaries, clothing, human remains, and other remnants of the war have been material reminders of the war for the past century. Military involvement is still symbolically and archaeologically evident in environmental features, landscape representations, commemorative practices, and the daily life of the local residents. The landscape and diverse artifacts still stand as a memorial to the war, but are open to ongoing reinterpretations by individuals and particularly local and national institutions involved in heritage construction and commemoration practices. 


\section{ACKNOWLEDGEMENTS}

The article was written within the project Heritage of the First World War: Representations and Reinterpretations (J6-7173), which was financially supported by the Slovenian Research Agency.

\section{REFERENCES}

Árnason, Arnar 2010. Grief Paves the Way. In: Karl Benediktsson \& Katrín Anna Lund (eds.) Conversations with Landscape. Farnham, UK: Ashgate, pp. 79-96.

Bajuk Senčar, Tatiana 2005. Kultura turizma: Antropološki pogled na razvoj Bohinja. [Culture of Tourism: Anthropological Perspective on the Development of Bohinj.] Ljubljana: Založba ZRC.

Bajuk Senčar, Tatiana 2018. From the Hinterland: Commemorating the Centenary of World War I in Bohinj. Folklore: Electronic Journal of Folklore, Vol. 73, pp. 47-66. https://doi.org/10.7592/FEJF2018.73.bajuk.

Bender, Barbara 1993. Introduction: Landscape - Meaning and Action. In: Barbara Bender (ed.) Landscape: Politics and Perspectives. Oxford: Berg, pp. 1-17.

Bender, Barbara 2001a. Introduction. In: Barbara Bender \& Margot Winer (eds.) Contested Landscapes: Movement, Exile and Place. Oxford: Berg, pp. 1-18.

Bender, Barbara 2001b. Landscapes on-the-Move. Journal of Social Archaeology, Vol. 1, No. 1, pp. 75-89. http://dx.doi.org/10.1177/146960530100100106.

Bender, Barbara 2002. Time and Landscape. Current Anthropology, Vol. 43, No. S4, pp. 103-112. http://dx.doi.org/10.1086/339561.

Bender, Barbara \& Winer, Margot (eds.) 2001. Contested Landscapes: Movement, Exile and Place. Oxford: Berg.

Budkovič, Tomaž 1999. Bohinj 1914-1918: Med fronto in zaledjem. [Bohinj 1914-1918: Between the Frontline and the Hinterland.] Klagenfurt: Mohorjeva družba.

Cosgrove, Denis 1984. Social Formation and Symbolic Landscape. London: Croom Helm.

Cosgrove, Denis \& Daniels, Stephen (eds.) 1988. The Iconography of Landscape. Cambridge: Cambridge University Press.

Cresswell, Tim 2004. Place: A Short Introduction. Oxford: Blackwell.

Daniels, Stephen \& Cosgrove, Denis 1988. Introduction: Iconography and Landscape. In: Denis Cosgrove \& Stephen Daniels (eds.) The Iconography of Landscape. Cambridge: Cambridge University Press, pp. 1-10.

Dimitrova, Snezhana 2005. "Taming the Death": The Culture of Death (1915-1918) and Its Remembering and Commemorating through First World War Soldier Monuments in Bulgaria (1917-44). Social History, Vol. 30, No. 2, pp. 175-194. Available at https://www.tandfonline.com/toc/rshi20/30/2?nav=tocList, last accessed on 12 September 2018.

Feld, Steven \& Basso, Keith H. 1996. Senses of Place. Santa Fe: School of American Research Press. 
Fikfak, Jurij \& Bajuk Senčar, Tatiana 2015. Triglavski narodni park: Akterji, strategije, problemi, rešitve. [Triglav National Park: Actors, Strategies, Problems, Solutions.] Traditiones, Vol. 44, No. 1, pp. 7-27. http:// doi.org/10.3986/Traditio2015440101.

Hirsch, Eric 1995. Introduction. Landscape: Between Place and Space. In: Eric Hirsch \& Michael O'Hanlon (eds.) The Anthropology of Landscape: Perspectives on Place and Space. Oxford: Clarendon Press, pp. 1-30.

Iles, Jennifer 2003. Death, Leisure and Landscape: British Tourism to the Western Front. In: Mark Dorrian \& Gillian Rose (eds.) Deterritorialisations... Revisioning Landscapes and Politics. London: Black Dog Publishing, pp. 234-243.

Ingold, Tim 1993. The Temporality of the Landscape. World Archaeology, Vol. 25, No. 2 , pp. 152-174. http://dx.doi.org/10.1080/00438243.1993.9980235.

Ingold, Tim 2000. The Perception of the Environment: Essays on Livelihood, Dwelling and Skill. London: Routledge.

Ingold, Tim \& Vergunst, Jo Lee (eds.) 2008. Ways of Walking: Ethnography and Practice on Foot. Aldershot, UK: Ashgate.

Jezernik, Božidar \& Fikfak, Jurij (eds.) 2018. Cultural Heritage of the Great War. Traditiones, Vol. 47, No. 1. DOI: 10.3986/Traditio20184701.

Keller, Tait 2009. The Mountains Roar: The Alps during the Great War. Environmental History, Vol. 14, No. 2, pp. 253-274. http://dx.doi.org/10.1093/envhis/14.2.253.

Kozorog, Miha 2018. Knowledge of Place in Three Popular Music Representations of the First World War. Folklore: Electronic Journal of Folklore, Vol. 73, pp. 67-94. https://doi.org/10.7592/FEJF2018.73.kozorog.

Kravanja, Boštjan 2018. Learning by Collecting: Amateur Collectors and Their Shifting Positions in Isonzo Front Heritagization and Tourism Adaptation. Folklore: Electronic Journal of Folklore, Vol. 73, pp. 95-116. https://doi.org/10.7592/ FEJF2018.73.kravanja.

Lloyd, David W. 1998. Battlefield Tourism: Pilgrimage and the Commemoration of the Great War in Britain, Australia and Canada, 1919-1939. Oxford: Berg.

Lund, Katrín Anna \& Benediktsson, Karl 2010. Introduction: Starting a Conversation with Landscape. In: Karl Benediktsson \& Katrín Anna Lund (eds.) Conversations with Landscape. Farnham, UK: Ashgate, pp. 1-12.

Luthar, Oto 2011. "Dokler nas smrt ne loči”: Moderna spominska pokrajina in nacionalizacija kolektivnega spomina po prvi svetovni vojni. [Until Death Do Us Part: Modern Memorial Landscape and Nationalization of Collective Memory of the First World War.] In: Tanja Petrović (ed.) Politike reprezentacije v Jugovzhodni Evropi na prelomu stoletij. Ljubljana: Založba ZRC, pp. 173-199.

Massey, Doreen 2006. Landscape as a Provocation: Reflections on Moving Mountains. Journal of Material Culture, Vol. 11, No. 1-2, pp. 33-48. Available at http:// journals.sagepub.com/toc/mcua/11/1-2, last accessed on 13 September 2018.

Morris, Mandy S. 1997. Gardens 'For Ever England': Landscape, Identity and the First World War British Cemeteries on the Western Front. Ecumene, Vol. 4, No. 4, pp. 410-434. Available at https://www.jstor.org/stable/i40178201, last accessed on 13 September 2018.

Repič, Jaka 2014. Gibanje kot prostorske prakse in ekonomske strategije na primeru družinskega sirarstva v Bohinju. [Movement as Spatial Practices and Economic Strategies in Cheese Production at Family Farms in Bohinj.] Ars \& humanitas: 
Revija za umetnost in humanistiko / Journal of Arts and Humanities, Vol. 8, No. 1, pp. 38-57. DOI: 10.4312/ars.8.1.38-57.

Saunders, Nicholas J. 2001a. Matter and Memory in the Landscapes of Conflict: The Western Front 1914-1999. In: Barbara Bender \& Margot Winer (eds.) Contested Landscapes: Movement, Exile and Place. Oxford: Berg, pp. 37-53.

Saunders, Nicholas J. 2001b. Apprehending Memory: Material Culture and War, 19191939. In: John M. Bourne \& Peter H. Liddle \& Ian R. Whitehead (eds.) The Great World War, 1914-1945. Vol. 2: Who Won? Who Lost? London: HarperCollins, pp. 476-488. Available at http://www.academia.edu/2424285/, last accessed on 13 September 2018.

Saunders, Nicholas J. 2002. Excavating Memories: Archaeology and the Great War, 1914-2001. Antiquity, Vol. 76, No. 291, pp. 101-108. http://dx.doi.org/10.1017/ S0003598X00089857.

Saunders, Nicholas J. 2003. Trench Art: Materialities and Memories of War. Oxford: Berg. Saunders, Nicholas J. 2004. Material Culture and Conflict: The Great War, 1914-2003. In: Nicholas J. Saunders (ed.) Matters of Conflict: Material Culture, Memory and the First World War. London: Berg, pp. 5-25. Available at http://www.academia. edu/2358286/, last accessed on 13 September 2018.

Saunders, Nicholas J. 2013. Anthropology and Archaeology of the First World War. Cadernos do CEOM - Patrimônio, Memória e Identidade, Vol. 26, No. 38, pp. 1731. Available at https://bell.unochapeco.edu.br/revistas/index.php/rcc/article/ viewFile/1684/927, last accessed on 30 July 2018.

Tilley, Christopher Y. 1994. A Phenomenology of Landscape: Places, Paths and Monuments. Oxford: Berg.

Tilley, Christopher 2012. Walking the Past in the Present. In: Arnar Árnason \& Nicolas Ellison \& Jo Vergunst \& Andrew Whitehouse (eds.) Landscapes Beyond Land: Routes, Aesthetics, Narratives. New York \& Oxford: Berghahn, pp. 15-32.

UNESCO Tentative Lists. Available at https://whc.unesco.org/en/tentativelists/6077/, last accessed on 12 September 2018.

Wilson, Ross J. 2011. Tommifying the Western Front, 1914-1918. Journal of Historical Geography, Vol. 37, No. 3, pp. 338-347. http://dx.doi.org/10.1016/j.jhg.2011.01.001.

Winter, Jay 1998 [1995]. Sites of Memory, Sites of Mourning: The Great War in European Cultural History. Cambridge: Cambridge University Press.

Winter, Jay 2006. Remembering War: The Great War between Memory and History in the Twentieth Century. New Haven \& London: Yale University Press.

Woodward, Rachel 2014. Military Landscapes: Agendas and Approaches for Future Research. Progress in Human Geography, Vol. 38, No. 1, pp. 40-61. http://dx.doi. org/10.1177/0309132513493219. 


\title{
FROM THE HINTERLAND: COMMEMORATING THE CENTENARY OF WORLD WAR I IN BOHINJ
}

\author{
Tatiana Bajuk Senčar \\ Institute of Slovenian Ethnology \\ Research Centre of the Slovenian Academy of Sciences and Arts, Slovenia \\ email: tatiana.bajuk@zrc-sazu.si
}

\begin{abstract}
The centenary of World War I has been marked by a broad range of commemorative practices across Europe. This has also been the case in Bohinj, a region located in the Julian Alps in the northeastern corner of present-day Slovenia. This article is an examination of the diverse practices of commemoration and heritagization of World War I in Bohinj against the backdrop of contemporary global developments that frame the centenary: the rise of war tourism and the globalization of heritage as an evermore important element of identity construction as well as the political economy of tourism. To what extent do these contemporary trends inform the specific nature of current commemoration and heritagization practices? Their study - together with an analysis of the actors that produce, enact, resist or promote them - aids in identifying and analyzing the diverse social processes that shape Bohinj's present landscape of war heritage.
\end{abstract}

Keywords: Bohinj, commemoration, heritagization, hinterland, Isonzo Front, tourism, World War I

\section{INTRODUCTION}

The centenary of World War I has been marked by a broad range of commemorative practices across Europe. This has also been the case in Bohinj, a region located in the Julian Alps in the northeastern corner of present-day Slovenia. Bohinj's residents experienced World War I in a number of ways: from being drafted to fight in faraway frontlines, staying home to maintain farms and households, to working in diverse ways in the hinterland supply system set up in Bohinj for the Isonzo Front. These multiple - overlapping, diverse - experiences point to the complex social reality of Bohinj during these years, a reality that has been invoked in numerous ways in the course of this important anniversary. 
This article ${ }^{1}$ is an examination of the diverse practices of commemoration and heritagization (Hewison 1987; Walsh 1992) of World War I in Bohinj against the backdrop of contemporary global developments that frame the centenary. These include the rise of war tourism (Butler \& Suntikul 2013; Kovacs \& Osborne 2014) and the globalization of heritage as an evermore important element of identity construction as well as the political economy of tourism (Bendix 2008; Kirshenblatt-Gimblett 2004; Salazar 2012). These overlapping processes reflect a rising interest in the past, which manifests itself in multiple, interlocking spheres (Macdonald 2013), including those of memory, identity, and heritage. To what extent do these contemporary trends inform the specific nature of current World War I commemoration and heritagization practices (Jansen-Verbeke \& George 2013)? Their study - together with an analysis of the actors that produce, enact, resist or promote them - aids in identifying and analyzing the diverse social processes that shape Bohinj's present landscape of war heritage.

This question builds upon a broad range of research on the ways in which World War I commemorative practices have shifted over time and across contexts, expressing particular priorities and values (Ashley 2016). For example, monuments built soon after the war often had a more personal purpose, as they were meant to be sites at which people could mourn their loved ones lost to the war, while later monuments were built to honor all those who sacrificed their lives for the nation and the empire (Winter 1995).

Researchers of World War I commemorations have also highlighted the contested nature of memorials and memorial practices, and the selection of memories, actors, and experiences they were meant to articulate, which implied that memorial practices were inevitably accompanied by acts of forgetting. The practices of forgetting are also context-specific. For example, numerous researchers (e.g. Fussell 1977 [1975]; Mosse 1990) have depicted the erasure of the traces of war from the physical landscapes soon after the war-including the landscape of battlefields - which was meant to help societies return to normal life. This trend was later reversed with the restoration of war landscapes and the creation of open-air museums (Winter 2009), which form an integral part of the contemporary range of commemorative landscapes and were also the sites for a number of World War I centenary events. These sorts of developments can also be seen in Slovenia, which has in recent decades rebuilt and restored sections of the Isonzo Front that have been linked together to form a memorial hiking trail called The Path of Peace, of which Bohinj became a part in 2015 a central event in Bohinj's World War I centenary celebration.

Assessing the role of contemporary trends and broader-based processes in a specific locality such as Bohinj requires the framing of centenary events against the backdrop of existing wartime experiences of social actors as well as within 
the broader history of commemorative practice. This facilitates the identification of continuities as well as changes over time. Furthermore, focusing on social actors and groups and their operation on numerous scales - local, regional, transnational - provides the foundation for teasing out specific features of these practices and the nature of their links to global trends. Thus the ethnographic analysis of Bohinj's marking of the World War I centenary follows upon a brief history of Bohinj's wartime experience and of World War I commemoration and heritagization practices - both tangible and intangible - with an emphasis on the period from Slovenia's independence onwards.

\section{WORLD WAR I AND THE PRODUCTION OF BOHINJ AS A HINTERLAND}

Bohinj's experience of the war can be divided into three phases: 1914-1915, during which time Bohinj's able-bodied men were mobilized, trained, and sent off to war (most of them to the Russian front); 1915-1917, from the point Italy entered the war to the last battle of the Isonzo Front; and the third from 1917 to the end of the war in 1918. At the onset of the war, the Austro-Hungarian army imposed a zoning system onto the imperial landscape, of which presentday Slovenia was a part. In so doing they demarcated combat or battle zones (Kriegsgebeit) - in which the army exercised absolute authority - and outlying areas (Hinterland). Combat zones were broken down further into operational combat regions (Operationsbereich) and intermediate/buffer regions (Etappenbereich), defining them primarily in accordance to their proximity to ongoing conflicts (Budkovič 1999).

Italy's entrance into the war brought with it the opening of a new frontline, the Isonzo Front, located within the Posočje region of present-day Slovenia. In addition, it also resulted in a re-zoning of Slovenia, with Bohinj falling within a so-called buffer/intermediate region (Etappenbereich), meaning that it was to operate as an intermediary area between the zone of combat, strictly speaking, and the outlying regions. Once Italy had entered the war, the military command defined hinterland supply systems for each section of the Isonzo Front. Bohinj became part of one such system due to its position along the railway and its relative proximity to part of the frontlines. Bohinj thus played an important role in the transport of supplies and soldiers to a certain part of the front, a region behind the frontlines for training troops before sending them to the front and caring for the sick and wounded.

Hinterland supply systems in general and that of Bohinj in particular were responsible for providing virtually everything needed on the front, a difficult 


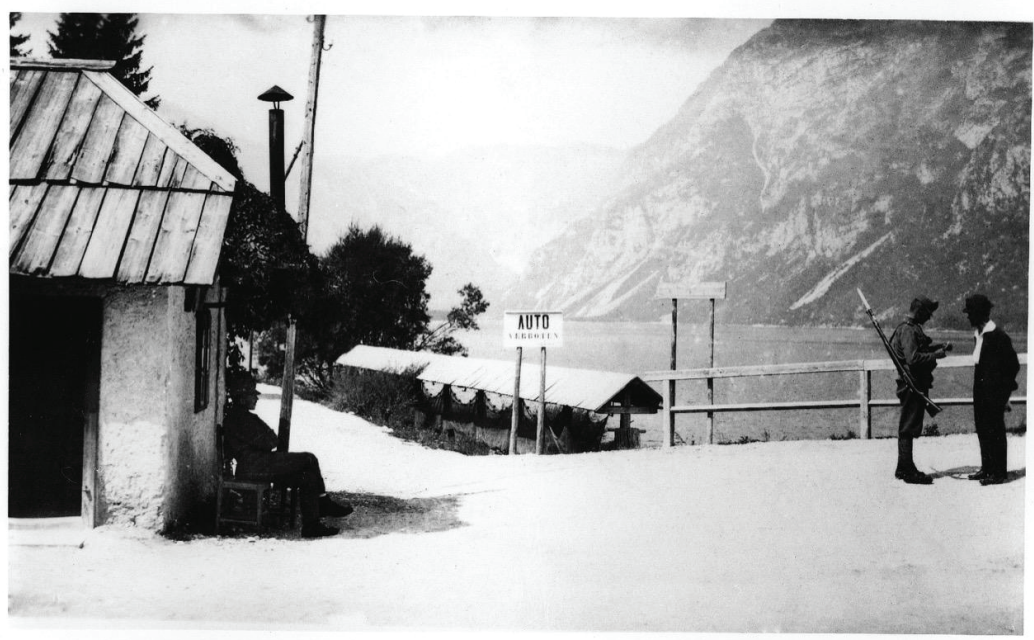

Figure 1. A military police officer inspecting the documents of a civilian before entering the restricted zone by Lake Bohinj. The documents of soldiers and civilians who entered the restricted zone of the hinterland system were thoroughly inspected. Courtesy of the National Museum of Contemporary History, Slovenia.

task given that the front was located in remote, mountainous terrain. Local historian Tomaž Budkovič in his research on Bohinj's role as a hinterland supply system estimates that five persons were necessary to provide everything needed for each soldier on the frontlines (Budkovič 1999). This included basics such as clothing, food and water, medicines, heating materials, lighting materials, construction material, motor fuel, and of course ammunition. Given that Bohinj also served as a training center and the place that provided medical care and convalescence for the wounded, it was in most respects the last stop for soldiers before going to the front and the first stop upon leaving the front.

The incorporation of Bohinj into a hinterland supply corridor brought with it significant changes. At the outset, the route for the supply corridor was primarily composed of badly maintained roads, and a significant part of it via mountainous terrain. Considerable effort was expended to build the necessary infrastructure to make the system work effectively.

This included a narrow gauge railway through the valley that was later powered by electricity as well as the necessary power plant, the expansion of footpaths through mountainous terrain to allow for the transportation of supplies, and finally, the building of a cable-car system. The infrastructure built for the supply system also included a number of buildings, from supply warehouses by the railway, barracks for soldiers as well as for prisoners of war, and 
numerous buildings with different functions in the mountain supply camps. In addition to the new buildings erected all along the supply corridor, a number of existing structures were also adapted to serve diverse purposes in the hinterland supply system. For example, hotels and castles were transformed into hospitals, and the agricultural cooperative centers and the municipal center became rehabilitation facilities. In essence, in a few short years, an entire system was put in place in Bohinj, which transformed daily life for those residents who were not mobilized into combat.

What did the creation of a supply system in Bohinj imply in terms of wartime experience for those who lived there? Most importantly, it implied the incorporation of an exceptionally broad range of social actors - besides local men mobilized onto far-off frontlines - into the daily life of war. Bohinj residents were involved in building the infrastructure necessary for the supply corridor through the Bohinj Valley and in the mountainous terrain, the operation of the supply corridor, the training of soldiers, the housing of officers or the care for the wounded. Furthermore, thousands of soldiers also came through Bohinj, some solely on the way to the frontlines, others stayed longer for either training or convalescence. Those soldiers who did not survive wounds or disease remained buried in Bohinj's military cemeteries. How have these experiences been remembered in the years after the war, and more importantly, during the war centenary?

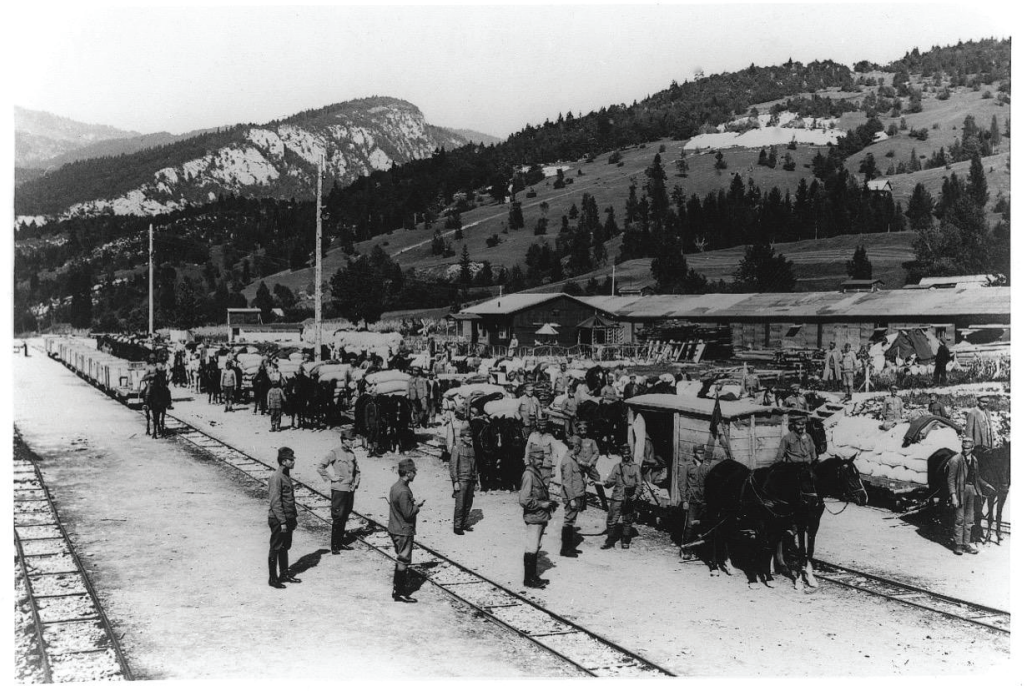

Figure 2. The first station of the narrow gauge horse-drawn railway in Bohinjska Bistrica. Courtesy of the National Museum of Contemporary History, Slovenia. 


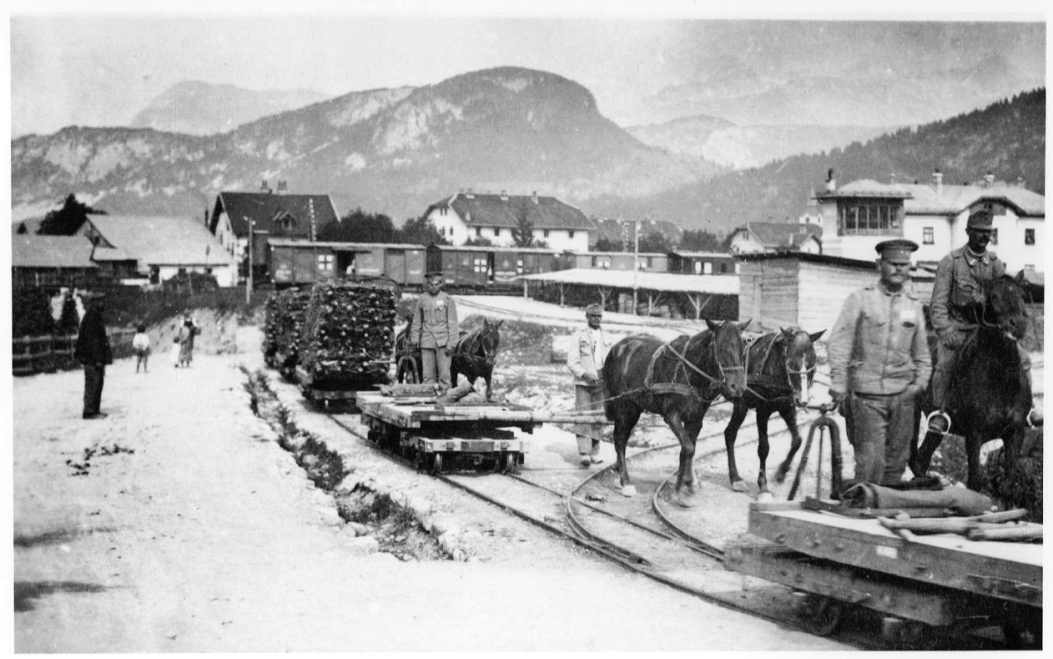

Figure 3. Narrow gauge horse-drawn railway, 1915-1916. The horse-drawn railway was the first section of the hinterland supply system, which ran from the train station to the eastern end of Lake Bohinj. Courtesy of the National Museum of Contemporary History, Slovenia.

\section{COMMEMORATIVE PRACTICES OF WORLD WAR I}

Practices aimed at honoring the fallen began already during the war by erecting monuments to those Bohinj soldiers who had lost their lives as well as by establishing military cemeteries for those soldiers who had died in Bohinj from battle wounds or diseases. Before World War II, two monuments were built near the village churches of Koprivnik and Srednja vas in the memory of the parishioners who had lost their lives in battle. Three military cemeteries were actually established during the course of World War I. The first one was in Bohinjska Bistrica, where they buried those who had died in the military hospitals that operated in the village in 1915-1917. The second cemetery, located in the village of Ukanc, is the final resting place for soldiers who died on the Isonzo Front close to Bohinj (Mt. Krn) and in Ukanc, as well as for a small number of prisoners of war. The third cemetery was located in the alpine meadow Planina na Kraju, which was the final resting place primarily for Hungarian soldiers. These remains were, however, moved before the beginning of World War II and stored in an ossuary built in the shape of a pyramid in the same area (Budkovič 1999). 




Figure 4. World War I military cemetery Rebro in Bohinjska Bistrica. The cemetery comprises 285 marked graves of Austro-Hungarian soldiers and Russian prisoners of war. Photograph by the author 2016.

For many decades, these monuments and cemeteries were the primary sites of any memorial practices or services dedicated to honoring those who had lost their lives in the war. Most of them were organized as part of November 1 holiday, dedicated to remembering and honoring the departed, and can be divided into two categories: those held for Bohinj soldiers who had lost their lives in the war, and those held at military cemeteries for the soldiers who had died in Bohinj. The former were organized primarily at existing monuments and consisted mainly in the laying of wreaths. In recent years, the commemoration ceremonies conducted at the military cemeteries have become more elaborate, particularly the one that has been held at the military cemetery in Ukanc since 1993. A local tourist association that was entrusted with the upkeep of the cemetery has been organizing another event for several years, one that has been intended for a much broader audience. One of the persons most actively involved in this ceremony, which is hosted by the tourist association along with the municipality, explains that ambassadors of all the nations whose soldiers are buried in Bohinj are invited. ${ }^{2}$ These include Hungary, Austria, Italy, Poland, Ukraine, Czech Republic, Slovakia, Romania, Russia, Croatia, Bosnia, Serbia and Montenegro. Attendance fluctuates from one year to the next; however, ambassadors 
from certain countries - Hungary, for example - are always present. National representatives, while invited, are absent, usually sending a wreath. The entire ceremony, led by the parish priest of Srednja vas and hosted by the mayor of Bohinj, lasts almost an hour. The ceremony is meant to preserve the memory of all those who are buried here and to promote a message of peace: to remember what happened so that it may never happen again.

Numerous other practices emerged in later decades, which focus primarily on what happened to Bohinj and its residents during the war and how the war became etched into landscapes, local experience, and social memory. One such practice involved the collection of material artifacts, originating from the Bohinj landscape and preserved and passed down through generations. Local actors played an important role in this regard: for example, Tomaž Budkovič, a geologist by profession, had a passion for local history and was an avid collector of war artifacts. Together with his colleagues Janko Stušek and Lovro Vojvoda, he collected the artifacts to create Bohinj's first World War I museum called Mali vojni muzej (Small war museum) in 1989, one of the first museums in Slovenia dedicated to World War I.

The 1990s also marked an increase in diversity among commemorative practices, including the collection of material artifacts, the production of local wartime history, and the organization of memorial hikes to the frontline region. Local figures were key to the production and dissemination of local World War I history. One of the most prominent figures is Tomaž Budkovič, who was one of the founders of the Bohinj's World War I museum. When the museum was opened in 1989, Budkovič was asked to write a brochure for the collection, which became a source of inspiration for the first historical monograph on Bohinj's World War I history, providing a detailed description of its role as a hinterland system for the Isonzo Front (Budkovič 1999). He is recognized as one of the leading experts on local history and has written numerous books on Bohinj's twentieth-century history. He wrote a second book on World War I on the eve of the centenary, based on the correspondence between a Bohinj soldier who fought on the Isonzo Front and his family (Budkovič 2014).

Another important practice involves the compilation of oral histories in the form of narrated experiences. While local historical sources focusing on World War I that centered on the local daily life in Bohinj during the war were based primarily on existing written sources (both local and non-local), oral history focused on daily life experiences as they have been preserved in narratives. Marija Cvetek, a local ethnologist and linguist, has compiled an anthology of 53 such narratives, transcribed in the local dialects (Cvetek 2014) of Bohinj's numerous villages. They depict many facets of life experience during the war, including seeing off those mobilized to the frontlines, carrying on daily life in 
the face of the absence of those gone off to war, dealing with the presence of foreign soldiers in the valley - and even in one's homes.

A final commemorative practice that also has had significant implications for the heritagization of Bohinj's World War I experiences is linked to hiking in the mountainous region along the Isonzo frontline as a way of remembering those who fought and perished on the front. Local alpine clubs, veteran organizations, and local police chapters decided to organize the first such memorial hike to Lake Krn to commemorate the end of World War I and those fallen on the Isonzo Front in 1997. While this memorial walk under the name "Krn - pohod spomina / Krn - memorial hike" initially involved local clubs, organizations, and chapters in the immediate vicinity of the Isonzo Front line, it soon took on broader dimensions as organizations from Bohinj, including the local alpine clubs and the war museum, also participated in the memorial hike from the Bohinj Valley. In addition, national and international officials also attended the memorial services. The memorial hike has continued to be held every year through to the present day.

\section{HERITAGIZING BOHINJ'S WARTIME EXPERIENCE}

Slovenia's declaration of independence in 1991 represents an important historical milestone in the commemoration of World War I, as it was in this period that certain elements or practices became subject to heritagization. By heritagization I mean the metacultural processes that allow for a negotiation and revalorization of the past for the constitution of a community and a collective identity in the present (Herzfeld 2010; Kirshenblatt-Gimblett 2004). The cemeteries in Bohinjska Bistrica and Ukanc were accorded the status of cultural monuments and have undergone restoration and renovation, which marked the beginning of the World War I heritagization in Bohinj at the national level. Local level, bottom-up processes carried out by local actors are more diverse in nature and are related to the growing significance linked to remembering and reframing Bohinj's World War I history and experience in the public sphere.

One could consider the creation of the Mali vojni muzej in 1989 not only an act of public commemoration but also of heritagization, as collections of material artifacts are presented in the museum for the public. It presently forms part of a larger museum - the Tomaž Godec Museum in Bohinjska Bistrica - that houses numerous exhibits related to Bohinj's history. The museum is of course presented as one of Bohinj's tourist attractions and has been incorporated into the regional association of museums in the Gorenjska region of Slovenia. Another significant practice of heritagization in this regard concerns the extent to 
which local tourism actors incorporate World War I historical sites as significant sites on tours of Bohinj. A local tour guide that I spoke to mentioned that war cemeteries were often neglected during tours of Bohinj - it is rather ironic, as the war cemetery of Ukanc is located in a wooded area only a few hundred meters from Lake Bohinj, and thus hard to overlook. However, this attitude has changed in recent decades, and the tour guide explained:

Many of us, when we put together a program, include the cemetery especially if we have a group, and especially that of foreigners. If we take them to the Vogel [ski lift], there is a footpath to the lake that takes you past the cemetery, so it is a logical stop. It can be an important element of Bohinj's tourist image for those of the older generation, if they have some sort of understanding of the war. ${ }^{3}$

Among the largest World War I heritagization projects, one finds a proposal for a thematic hiking trail in Bohinj that is meant to link historically significant sites and routes distinctive to Bohinj's wartime experiences. The idea of this historical thematic route first emerged in the context of the 20th anniversary of Triglav National Park in 2001, but became a concrete proposal when published as part of Bohinj's tourism development program for the years 2006-2013. This is one of a number of hiking trails that were developed to strengthen Bohinj's tourism program, and extends its tourist high season, which is in the summer.

The proposal states that the purpose of the thematic trail was to link all the more interesting sites in the area under the rubric of World War I, the Isonzo Front and its supply system. The idea for a memorial trail was based on three factors: that Bohinj was a supply hinterland for the Isonzo Front from 1915 onwards, that experts identified a number of sites that could be interesting for tourists, and finally, that many tourists and locals were interested in sites linked to the war (Občina Bohinj 2006).

The thematic trail, marked by seven billboards along a route from Lake Bohinj up to the Bogatin supply camp, was inaugurated the following year. The path linked numerous sites along the former supply trail and reframed them as part of the memorial route dedicated to Bohinj's wartime experience, including the supply route itself through the mountains above Bohinj Lake, the military cemeteries and Bohinj's war museum. The inauguration of the thematic trail coincided with the Krn Lake Memorial Hike, and was attended by local hikers, cultural and/or hiking organizations as well as politicians - both from Bohinj and from regions linked to the Isonzo Front (Langus 2007). Inauguration organizers thus claimed a connection between the new thematic trail they had created and the existing commemorative hiking practices carried out in what was the landscape of the Isonzo Front, thus rendering explicit the broader 
framework in which they wished to place Bohinj's new trail. Furthermore, they added a new layer of meaning to the sites they connected by reframing them into a single tourist attraction.

\section{THE WORLD WAR I CENTENARY IN BOHINJ}

It is thus apparent that in recent decades considerable developments have occurred in the production, commemoration, and heritagization of Bohinj's World War I history and experience on diverse levels. How have Bohinj social actors marked the centenary, particularly in relation to the established range of practices mentioned above? Upon looking at the list of events prepared for the different years of the war centenary, one can make a distinction between events that could be defined as new practices particular to the centenary and events that draw upon established practices or are incorporated into them. New practices, for example, included a soccer game organized in remembrance of the game played by soldiers from opposing sides in no man's land during the 1914 ceasefire; local museum exhibits held in Bohinj on different aspects of the war, and a theater production put on by a local theater company.

The majority of the events, however, involve reframing existing memorial sites or being incorporated into existing series of events. For example, one such event was the (re)opening of the renovated Tomaž Godec Museum in Bohinjska Bistrica, which houses exhibitions of Bohinj's natural and cultural heritage, in which the collection of the Mali vojni muzej has found a permanent home. In addition, certain events marking the World War I centenary were incorporated into existing festivals that take place during the course of the year, including the International Wildflower Festival held in late spring, the Bohinj Summer Music Festival, and the Bohinj Hiking Days held in the autumn months.

For example, the International Wildflower Festival in the year 2015 included an exhibition of the work of photographer Peter Strgar on the theme Vojna in cvetje (Flowers and war), in which the photographer portrays the many sorts of relationships between the two. He depicts the important role of flowers in honoring victims of war and how war itself influences the flora of conflict zones, with the mobility of soldiers and livestock facilitating the introduction of new species into the landscape around Mt. Krn above Bohinj Lake (Sodja 2015). Furthermore, a special concert featuring Mozart's Requiem was included in the Bohinj Summer Music Festival program, which was dedicated to all who lost their lives in both world wars, as 2015 marked the 70th anniversary of the end of World War II. 
In addition, one of the most important events was held within the framework of the Bohinj Hiking Days in 2015, marking the incorporation of the thematic hiking trail along the hinterland supply route in Bohinj into a leg of the celebrated Walk of Peace hiking trail along the Isonzo Front. The (re)opening of the memorial trail as a leg of the Walk of Peace was dedicated to the memory of the then recently departed Tomaž Budkovič, who had played such an important role in documenting and memorializing Bohinj's World War I history by different media. It was, in effect, a two-day event that took place in early October 2015 and was organized by local tourism association and alpine clubs. Participants started out to Bogatin (under Mt. Krn) in mid-afternoon, and the ceremony included a cultural program as well as a speech memorializing Budkovič's work. The second day began with a mass for all those who had lost their lives in the war, and the ceremonial opening of the memorial trail as a leg of the Walk of Peace.

The memorial two-day hike to the base of Mt. Krn has been repeated each year. In 2016, Bohinj organized a similar two-day event to conclude its yearly Hiking Festival, and once again the event had a strong commemorative theme as it centered on Marija Cvetek's recently published collection of oral histories about the wartime experiences of Bohinj men and women during the war (Cvetek 2014). The theme of the 2017 memorial hike was the hundred-year anniversary of the battle of Kobarid (Caporetto) as a turning point in the Isonzo Front battles and its effect on Bohinj, given that the frontlines moved significantly eastward, towards the Piave River. The schedule included a talk given by Lojze Budkovič - Tomaž Budkovič's brother - about a neglected aspect of World War I hinterland history associated with the Sava Line, which was the final line of defense behind the Isonzo Front that also ran through Bohinj.

\section{COMMEMORATION, HERITAGIZATION, TOURISMIFICATION}

Stepping back to assess the numerous events that have been organized in the last years and dedicated to marking the World War I centenary, two things become clear. First, there is a strong continuity between past and present memorial practices, and the program marking the World War I centenary in Bohinj is rooted in established commemorative traditions. Second, there is no apparent break or discontinuity with the past when analyzing how Bohinj memorializes the centenary as a particular anniversary. In fact, it seems that remembering the war centenary has been incorporated into numerous aspects of public life in Bohinj, including the programs offered to Bohinj's visitors/tourists. It is, however, this ever-stronger association between tourism events and festivals 
and war commemoration that begs the question as to how contemporary trends in heritage management and tourism - war tourism, heritage tourism - inform the way that Bohinj actors decide are memorializing the centenary. What effect does the touristic framing of World War I commemoration have on how and why Bohinj residents remember local war experience and portray it to chosen audiences?

Most of the events that took place in Bohinj to mark the centenary were more commemorative than touristic in nature. The majority of them were presented as part of a nation-wide series of events marking the centenary of the Isonzo Front, and a national committee oversaw its organization and implementation. Bohinj's collaboration with the national committee and the purpose of the events is also apparent in the introductory wording of the schedule for the events of 2015:

On the anniversary of the beginning of the fighting on the Isonzo Front, we prepared a selection of events in cooperation with diverse organizations and associations with the purpose of remembering those cruel times and warning that history can repeat itself at any time; as a result, striving for peace should be one of the main missions of modern society. (Turizem Bohinj 2015)

The majority of events outlined in this schedule seem to have been intended primarily for the local or - at the broadest level - the national audience. Events were carried out primarily in Slovene; they took place in different local centers throughout Bohinj (including the local library, the municipal cultural center, and the local elementary schools), were carried out by social actors, and aimed at highlighting diverse aspects of local wartime experience in Bohinj. For example, the presentation of the collection of local oral history narratives, transcribed and collected by Marija Cvetek, was held in the municipal cultural center on 14 March 2015. The presentation included Marija Cvetek's reading of chosen narratives in local dialects as well as local actors' testimony of their parents or grandparents in the war. This presentation was repeated in the following weeks at the local elementary school, demonstrating the role of this collection as a means of presenting and transmitting local history and experience (Repinc 2015).

While certain scheduled events highlighted local features of the war, they also had a broader message that involved linking this local dimension to the story of the Isonzo Front and framing Bohinj's experience as a hinterland to the front. For example, the museum exhibit titled "Zdrav sem in dobro se mi godi / I am healthy and doing well”, organized by the Žiga Zois Museum Society, focused on propaganda in the Bohinj hinterland (Turizem Bohinj 2015). The re-opening 
of the World War I exhibit in the renovated Tomaž Godec Museum, dedicated to the hinterland supply system and the inauguration of the memorial trail as a leg of the Walk of Peace, would also fall into this category.

There were a number of events that transcended the language barrier and thus could be accessible to a broader audience. Furthermore, they also took place during the high season, when non-local actors were bound to be present; for example, the art and photography exhibitions as well as the temporary museum exhibits, some of which remained open also during the summer months. One such example was the exhibit titled "Proti vojni / Against War", by the artist Franc Rasinger in the Tomaž Godec Museum, which remained open during all the summer months. The pieces involved the superimposition of verses in Glagolitic Slavic script on collages of news headlines and war photographs meant to depict the senselessness of war, in itself a global message.

The range of intended audiences, however, did not necessarily define the range of meanings accorded to any given event. In fact, the most internationally-defined event - if one takes into account the range of participants - is the commemoration held on November 1 at the military cemetery in Ukanc. As was mentioned earlier, local officials and host organizations invite ambassadors from most of Europe to pay homage to those who lost their lives and are buried in the cemetery, far away from their homeland. The majority of the soldiers are Hungarian, and in recent years an organization called The Krajczáros Alapítvány Foundation has played an increasingly large role in maintaining the cemetery and the graves of Hungarian soldiers in Bohinj, including contributing funds for renovation and sending volunteers to help with the physical upkeep of the cemetery. Foundation representatives as well as the Hungarian ambassador to Slovenia have historically had a significant role in the November 1 ceremony, including a speech as well as a musical accompaniment. Thus, while the significant presence of Hungarian groups and political representatives renders this particular ceremony unique in Bohinj, this does not necessarily imply that it is meant to engage different sorts of audiences outside the commemorative sphere.

The fact that certain events were incorporated into established tourism festivals suggests that organizers were striving to address a broader audience what sorts of changes did this imply? What does this mean for the events' commemoration dimensions? These questions become particularly relevant when analyzing one of the events whose reframing speaks most to the issue of potential tourismification - the two-day memorial hike along the memorial trail along the hinterland supply route that was (re)inaugurated as a leg of the Path of Peace trail. The rebranding of the trail and its dedication to the memory of Tomaž Budkovič provided a forum not only for memorializing an important chapter of 
local and global history but also for celebrating the efforts of Bohinj local actors who have contributed to the preservation of Bohinj's wartime heritage - all of which falls within the scope and spirit of the Walk of Peace brand, which speaks both to the war commemoration and heritagization. But what can be said thus far about the tourismification of Bohinj's wartime heritage?

By tourismification I am referring to what Wang describes as "processes by which society and its environment have been turned into spectacles, attractions, playgrounds, and consumption sites" (Wang 2000: 197). Some theorists argue that the passing of time has facilitated the heritagization and/or tourismification of war sites and landscapes, based on their transformation from what Jansen-Verbeke and George term "private inheritance to collective claims" (Jansen-Verbeke \& George 2013).

Numerous researchers have demonstrated that the tourismification of local cultural landscapes can have negative or positive consequences, in some cases empowering and even promoting the resurgence of local identity. The impact of these changes is linked to the social and institutional actors making collective claims and the nature of the claims themselves. The sorts of actors, agendas, and measures taken to create a tourismified landscape at diverse scales can ultimately shape how this landscape is defined, promoted, and implemented. At the same time, the political and symbolic economy of the global tourism industry inform the extent of effective local agency. All of this implies that the concepts of top-down and bottom-up tourismification initiatives are not as discrete as they seem to be; nor are they mutually exclusive.

One such important factor that informs this dynamic in this case is the brand of the Walk of Peace itself, to which Bohinj actors lay claim with their renaming of the memorial hiking trail. The Walk of Peace trails in this region of Europe have a particular history. According to existing sources, the concept of the Peace Trails in the Alps is mainly the work of Austrian alpinist and military historian Walther Schaumann, who in 1973 began to work on restoring World War I landscapes in the South Tyrolean mountains and making them accessible to visitors under the label Peace Trail. In addition to the Walk of Peace in Slovenia, only two other trails have been granted permission to use the Walk of Peace brand: the Dolomitenfreunde Peace Trails in Austria and the Itinerare di Pace sul Carso della Grande Guerra in Italy. Each of these hiking trail projects operates under a similar premise - transforming what were ruins or traces of conflict into sites of wartime heritage while also arguing for the importance of peaceful cooperation in a borderland region (Wohlmuther \& Wintersteiner $\&$ Wagner 2014). Being able to use the Peace Trails brand is contingent upon presenting local and distinctive wartime landscapes in an accessible manner 
while promoting peace as a universal value. The brand seems to imply certain limits for peace trails as tourist attractions; however, the issue of how these limits are negotiated at the local level is one that requires further and more long-term research, as Bohinj has a very short history with the brand.

In addition to employing the memorial trail as a site for centenary commemorations, local tourist actors who have been involved in the creation and rebranding of the trail have additional expectations regarding the rebranded trail. One high-level tourist official remarked:

This new thematic trail also represents a link that will help bring together local tourist organizations from both regions. The Walk of Peace in the Posočje region is also connected to other hiking trails, such as, for example, the Alpe Adria Trail, and thus is able to attract many guests. This interconnection among hiking trails is very important, as the target group of tourists, who are interested in such trails, is quite large. ${ }^{4}$

This tourism official talks of forging connections in terms of tourism development and as a means or route for attracting increasing numbers of tourists and, more importantly, new groups of tourists, mobile actors who travel along particular routes to which Bohinj tourism wishes to connect. The creation of thematic, memorial paths forms part of a broader project of tourism development, with which Bohinj strives to expand its tourism season - which is condensed to a high season in the summer and a shorter one in the winter - with the aid of new tourist attractions (Bajuk Senčar 2015). How will these new forms of collaboration inform the evolution of the tourist landscape in Bohinj, and how will these sorts of connections inform the way that Bohinj operates as a commemorative landscape?

\section{CONCLUDING THOUGHTS: FORGING CONNECTIONS}

Contemplating the sorts of tourist connections that actors in Bohinj wish to generate and the potential impact that these connections (could) have on Bohinj - and potentially transforming it into a spectacle, playground or consumption site, to paraphrase Wang - should not take place in a vacuum. It is apparent that against the backdrop of the centenary Bohinj has become a site of numerous claims and practices of connection linked to the war during the centenary, not all of them being primarily touristic in nature. These largely operate as responses to the processes of displacement that shaped so much of the wartime experience. Bohinj men were sent off to war, many of them never to return, their resting places far from home. The memorials dedicated to Bohinj's soldiers are meant to honor their sacrifice, but also mark their (physi- 
cal) absence. On an analogous level, the military cemeteries in Bohinj provide a final resting place for soldiers who were also mobilized to fight on frontlines in foreign lands - with Bohinj locals operating as caretakers for a memorial dedicated primarily to those whose final resting place is located far from home. In addition, Bohinj's success as a key link in the hinterland supply chain and as a site for training and convalescence hinged on its operations as an effective system for the transportation of supplies and personnel along an established route, only traces of which are visible today.

Bohinj's efforts in commemorating the war in numerous ways and these processes of displacement involve identifying, marking, and honoring both present and absent wartime actors as well as conferring significance to traces of a wartime hinterland system. Upon analyzing the events and practices depicted over the course of this article, it becomes clear that the social actors who organize and perform them claim or enact some form of connection to these experiences. These claims articulate links to a particular landscape, to a shared history or heritage (local, national, global), links between hinterland and frontlines, and even to a common, global message of peace. The centenary as a landmark anniversary has become an opportunity to forge connections through diverse gatherings and practices - and in some cases, diverse forms of connection at the same time.

Thus the sorts of links that tourist actors try to forge with the reframing of the memorial trail along the hinterland supply route in an attempt to spur tourist development are set in a commemorative and touristic landscape informed by numerous registers of connection and collaboration. In certain cases, it is difficult to separate the commemorative from the touristic, as Bohinj's wartime history and experience has become an increasingly significant element of Bohinj's heritage as well as its identity, particularly its identity as a tourist destination.

Upon analyzing the range of events and practices that marked the World War I centenary, it becomes clear that Bohinj is not immune to contemporary global developments, including the rise of war tourism and the increasingly important role of heritage in numerous spheres of daily life. However, these developments - particularly if one assesses them in conjunction with the actors involved in their operation - have strong ties to established local forms of commemorative and touristic practice. In addition, certain regional and even transnational factors to which existing touristic forms of commemoration are now linked - including the limits of the Walk of Peace brand and the multidimensional nature of existing events - inform how war tourism has developed thus far in Bohinj. Time will tell what different forms of touristic practice understood as cooperation across physical and political borders will bring to local communities and how these new collaborative touristic practices will potentially inform the production of local wartime social memory. 


\section{NOTES}

1 The article is based on the research carried out for the research project titled Heritage of the First World War: Representations and Reinterpretations (2016-2018), funded by the Slovenian Research Agency (No. J6-7173). For more information about the project see Jezernik \& Fikfak 2018.

2 Anonymous interview with a local tourism association official. Ribčev Laz, 10 March 2017. During the course of my research in Bohinj, I interviewed approximately 15 people from March to July 2017. They included people in the municipality, in tourist organizations, museums, and other associations involved in the preservation of Bohinj's World War I heritage. The interviews are anonymous.

3 Anonymous interview with a local tourist guide. Bohinjska Bistrica, 12 April 2017.

4 Anonymous interview with a municipal tourism official. Bohinjska Bistrica, 18 May 2017.

\section{REFERENCES}

Ashley, Susan L.T. 2016. Acts of Heritage, Acts of Value: Memorialising at the Chattri Indian Memorial, UK. International Journal of Heritage Studies, Vol. 22, No. 7, pp. 554-567. http://dx.doi.org/10.1080/13527258.2016.1167107.

Bajuk Senčar, Tatiana 2015. The International Wildflower Festival and the Implementation of Sustainable Mobility as Touristic Practice. Traditiones, Vol. 44, No. 1, pp. 87-116. http://dx.doi.org/10.3986/Traditio2015440104.

Bendix, Regina 2009. Heritage Between Economy and Politics: An Assessment from the Perspective of Cultural Anthropology. In: L. Smith \& N. Akagaza (eds.) Intangible Heritage. London: Routledge, pp. 253-269. Available at http://www.academia. edu/8871467/Heritage_between_Economy_and_Politics._An_assessment_from_ the_perspective_of_cultural_anthropology, last accessed on 27 June 2018.

Budkovič, Tomaž 1999. Bohinj 1914-1918: Med fronto in zaledjem. [Bohinj 1914-1918: Between the Front and the Hinterland.] Celovec \& Ljubljana \& Dunaj: Mohorjeva založba.

Budkovič, Tomaž (ed.) 2014. S Turudijevim bataljonom na soškem bojišču: iz pisem poročnika Vladimirja Bregarja. [With the Turudi Battalion on the Isonzo Battlefield: From the Letters of Lt. Vladimir Bregar.] Celovec: Mohorjeva.

Butler, Richard \& Suntikul, Wantanee (eds.) 2013. Tourism and War. London \& New York: Routledge.

Cvetek, Marija 2014. Hude so res vojské...: Bohinjske pripovedi o 1. svetovni vojni. [The Armies Are Dreadful...: Bohinj Narratives on the First World War.] Celje: Celjska Mohorjeva družba.

Fussell, Paul 1977 [1975]. The Great War and Modern Memory. London: Oxford University Press. 
Herzfeld, Michael 2010. Engagement, Gentrification, and the Neoliberal Hijacking of History. Current Anthropology, Vol. 51, No. S2, pp. S259-S267. http://dx.doi. org/10.1086/653420.

Hewison, Robert 1987. The Heritage Industry: Britain in a Climate of Decline. London: Methuen.

Jansen-Verbeke, Myriam \& George, Wanda 2013. Reflections on the Great War Centenary: From Warscapes to Memoryscapes in 100 Years. In: Richard Butler $\&$ Wantanee Suntikul (eds.) Tourism and War. London \& New York: Routledge, pp. 273-287.

Jezernik, Božidar \& Fikfak, Jurij (eds.) 2018. Cultural Heritage of the Great War. Traditiones, Vol. 47, No. 1. DOI: 10.3986/Traditio20184701.

Kirshenblatt-Gimblett, Barbara 2004. Intangible Heritage as Metacultural Production. Museum International, Vol. 56, No. 1-2, pp. 52-65. https://doi.org/10.1111/j.13500775.2004.00458.x.

Kovacs, Jason F. \& Brian S. Osborne 2014. A Bibliography: The Great War (1914-1918). Halifax, NS: World Heritage Tourism Research Network, Mount Saint Vincent University. DOI: 10.13140/RG.2.1.3571.1523.

Langus, Klemen 2007. Nova tematska pot. [New Thematic Trail.] Bohinjske Novice, December, pp. 11-12. Available at https://obcina.bohinj.si/Files/ eMagazine/23/101997/Bohinjske_Novice_december2007.pdf, last accessed on 28 June 2018.

Macdonald, Sharon 2013. Memorylands: Heritage and Identity in Europe Today. London: Routledge. https://doi.org/10.1111/amet.12434.

Mosse, George L. 1990. Fallen Soldiers: Reshaping the Memory of the World Wars. New York \& Oxford: Oxford University Press.

Občina Bohinj 2006. Program razvoja turizma v Bohinju 2006-2013. [Bohinj Tourism Development Program 2006-2013.] Available at https://obcina.bohinj.si/files/ other/news/23/100029Program\%20razvoja\%20turizma\%20v\%20Bohinju\%20 2006-2013.pdf, last accessed on 28 June 2018.

Repinc, Urška 2015. Predstavitev nove knjige Marije Cvetek [Presentation of Marija Cvetek's New Book.] Bohinjske Novice, pp. 9-10. Available at https://obcina. bohinj.si/objava/101821, last accessed on 19 September 2018.

Salazar, Noel B. 2012. Shifting Values and Meanings of Heritage: From Cultural Appropriation to Tourism Interpretation and Back. In: Sarah M. Lyon \& E. Christian Wells (eds.) Global Tourism: Cultural Heritage and Economic Encounters. Lanhan: Altamira, pp. 21-41.

Sodja, Andraž 2015. Odprli Festival alpskega cvetja. [The Opening of the Alpine Flower Festival.] Gorenjski Glas, 27 May. Available at http://arhiv.gorenjskiglas.si/ article/20150527/C/150529832/odprli-festival-alpskega-cvetja, last accessed on 24 September 2018.

Turizem Bohinj $2015=100$. obletnica začetka bitk na Soški fronti. [Centenary of the Commencement of Fighting on the Isonzo Front.] Available at http://www2.bohinj.si/si/ novice/100_obletnica_zacetka_soske_fronte, last accessed on 19 September 2018.

Walsh, Kevin 1992. The Representation of the Past: Museums and Heritage in the Postmodern World. London: Routledge. 
Wang, Ning 2000. Tourism and Modernity: A Sociological Analysis. Oxford: Pergamon Press.

Winter, Caroline 2009. Tourism, Social Memory and the Great War. Annals of Tourism Research, Vol. 36, No. 4, pp. 607-626. http://dx.doi.org/10.1016/j. annals.2009.05.002.

Winter, Jay 1995. Sites of Memory, Sites of Mourning: The Great War in European Cultural History. Cambridge: Cambridge University Press.

Wohlmuther, Cordula \& Wintersteiner, Werner \& Wagner, Mira 2014. Connected by the Trails That Used to Divide Us: Peace Trails in the Alps-Adriatic Region. In: Cordula Wohlmuther \& Werner Wintersteiner (eds.) International Handbook on Tourism and Peace. Klagenfurt: Drava, pp. 321-334. Available at https://www.eunwto.org/doi/pdf/10.18111/9783854357131, last accessed on 29 June 2018. 


\title{
KNOWLEDGE OF PLACE IN THREE POPULAR MUSIC REPRESENTATIONS OF THE FIRST WORLD WAR
}

\author{
Miha Kozorog \\ Institute of Slovenian Ethnology \\ Research Centre of the Slovenian Academy of Sciences and Arts \\ Department of Ethnology and Cultural Anthropology \\ Faculty of Arts, University of Ljubljana, Slovenia \\ e-mail: miha.kozorog@ff.uni-lj.si
}

\begin{abstract}
This article explores three recent representations of the First World War - specifically of the Isonzo Front - in Slovenian popular music. It considers the works of Rodoljubac, Bakalina, and Bratko Bibič. These musicians and music collectives share a connection to the historical region of the Isonzo Front. The article investigates how these musicians' knowledge of place informed their compositions. Four ways of knowing a place are identified, distributed to varying degrees among the musicians: absorbing locally shared narratives about a place, engagement with landscapes and the environment, personal memories, and analyzing and reconsidering the place. The article contributes to the literature on the involvement of music in the production of place by examining the multitude of ways of knowing a place.
\end{abstract}

Keywords: centennial celebrations, First World War, Isonzo Front, popular music, production of place, Tolmin (Slovenia), (ways of) knowing a place

\section{INTRODUCTION}

This article explores three recent popular music representations of the Isonzo Front, a battlefield from the First World War. ${ }^{1}$ They are works by the following Slovenian musicians and music collectives: Rodoljubac, a garage rock and roll band; Bakalina, a "world music" chanson duo; and Bratko Bibič, an experimental accordion player and composer. In addition to dedicating part of their work to the Isonzo Front, these musicians also share a connection to a particular location in this battlefield. This is the Tolmin area, which has played a role in the musicians' lives, and which also appears to varying degrees in their musical works. 
These relations between place, musicians' lives, and musical representations of place call for an interpretation of music as stimulated by musicians' knowledge of the place, and perhaps their local belonging and/or identification with the place. The article follows this line of argumentation, but also demonstrates that quite different ways of knowing this place have stimulated the musicians to represent it in the context of the war. Different ways of knowing the place have also contributed to differences in knowing its history, and therefore to different portrayals of it.

Anthropological studies of relations between music and place gathered pace in the 1990s together with attention to globalization. This attention stimulated imagining traditional, ethnic, folk, and other musical styles as not place-bound (as they were previously imagined) because every place is always part of a larger world and thus culturally influenced from elsewhere (Connell \& Gibson 2003). At the same time, although music is spatially unbounded, local manifestations of music (of whatever kind) are very much influenced by the local conditions of its production (Cohen 1995; Finnegan 1989; Muršič 2000). Moreover, these conditions are also involved in the production of a particular place. This is the case for several reasons: music is integral to social events; as such, it engenders place-bound memories. Via reproduction, it marks local sound and style. Moreover, musicians, their works, audiences, record labels, events, venues, and so on frequently brand a place. Thus, for example, Sara Cohen (1995) portrayed an inhabitant of Liverpool, who through personal knowledge of the city's musical history reproduces its identity, using musical metaphors.

This article explores a related, yet less frequent inquiry: namely, how different ways of knowing a place stimulate different musical representations of it (which may afterwards function in processes of place production). Hence, although musical production of place has already attracted researchers' attention, involvement of a multitude of ways of knowing a place in this process has remained underexplored. Nevertheless, Steven Feld's classic (1982) on the Kaluli people of Papua New Guinea investigates their knowledge of sounds in the environment as constitutive for local musical language. However, a variety of ways of knowing a place by a set of musicians with different attitudes to place and their translation of this knowledge into music has remained underexplored.

Four ways of knowing a place have contributed to the musical works examined below: absorbing locally shared narratives about the place, engagement with local landscapes and the environment, personal memories, and analyzing and reconsidering the place. These ways of knowing are not exclusive, but are sometimes combined in a musician's experience of place. Nevertheless, they are distributed to varying degrees among the musicians so that in each case one or another stands out more distinctively than others. 
Because popular music representations of the First World War are a very recent phenomenon in Slovenia, it is worth asking how this phenomenon is connected (if at all) with the centennial of the war. The history of Slovenian popular music, as well as folk music, ${ }^{2}$ is very poor in representations of this specific war, and this might therefore suggest that the observed acts of music-making are pragmatic, in the sense that anniversaries can be profitable. For comparative purposes, consider that the Belgian town of Diksmuide commissioned a musical work dedicated to the centennial of the war from the German avant-garde rock band Einstürzende Neubauten. This led to the band's 2014 project Lament which, however, also stimulated a defense of the band's act by frontman Blixa Bargeld: "I have a problem with the avant-garde. Because it's a military term. It means the garde that runs before the rest of the soldiers and if I want to see myself represented in military terms, I don't want to be part of that. I want to be one of the deserters." 3 This comment may make one think that composing and performing for war anniversaries is not an unencumbered task because it is associated with moral ambiguity, possibly endangering a musician's or band's artistic coherence: can one still call Einstürzende Neubauten the "avant-garde" after it was commissioned to compose a piece for a war anniversary? I pay attention to this ambiguity as well. However, there is an important difference between the Diksmuide case and those presented here. Namely, none of the musicians examined here were commissioned by local authorities to compose for the centennial (although some were involved in local centennial programs), but were stimulated in some other way, primarily by their knowledge of the place.

With the cases presented here, I do not wish to reduce music-making to merely a derivative of specific experiencing and knowing of places by musicians. In the production of music, other forces play a considerable role; among these are the musicians' commitment to specific aesthetics, personal expression, and morality, as well as the rules of the musical genre. I take these into account as well.

Below I first present historical, geographical, and ideological frameworks of popular and folk music representations of the Isonzo Front. Then I present the relevant place, in relation to both its heritage and popular music. After this, I present the three musical groups or musicians and their local embeddedness. The conclusion interprets these works with diverse ways of knowing the place. 


\section{POPULAR AND FOLK MUSIC REPRESENTATIONS OF THE ISONZO FRONT: HISTORICAL, GEOGRAPHICAL, AND IDEOLOGICAL CONTEXTS}

The Isonzo Front refers to the battlefields between Austro-Hungary and the Kingdom of Italy, stretching from the Julian Alps to the Adriatic along the Isonzo or Soča River. ${ }^{4}$ During the war, this area was a fierce place, where the two armies found themselves in static combat between 1915 and 1917. In the decades since the First World War, the remnants and memories of the battlefield have been heritagized; however, this has been done to varying degrees by the different countries that inherited these lands. This analysis considers the following countries as contexts for heritagization: the Kingdom of Italy, postwar Italy, the Socialist Federal Republic of Yugoslavia, and independent Slovenia.

After the First World War, the entire area of the Isonzo Front became part of the Kingdom of Italy. Its concern was to carry on the memory of the war to nourish the ideals of heroism of Italian soldiers and citizens as well as to promote the Italian victory. The Italian soldiers were reburied in monumental ossuaries to serve as memorials of the war. In 1938, twenty years after the war, three huge ossuaries commemorating the Isonzo Front were erected and personally inaugurated by the country's leader, Benito Mussolini, who was a soldier on the Isonzo Front before he founded fascism.

A year later another world war started, after which the area of the Isonzo Front was divided between two countries: its western part belonged to Italy, and its eastern part to Yugoslavia. Whereas Italy preserved the memory of the First World War as a heroic era of its history, Yugoslavia instead glorified the Second World War. However, soon after the dissolution of Yugoslavia, when Slovenia became its successor in the Isonzo Front area, the battlefield became actively heritagized. In the 1990 s, it was enthusiastically rediscovered and represented by various local protagonists, so that an economically successful and publicly loud heritage industry found its place in the area, particularly in the town of Kobarid.

Popular music and folk music thematizing the First World War in general corresponded to these historical, geographical, and ideological frameworks. Already during the war, songs were composed in the different languages spoken at the battlefields, presumably also for propaganda purposes. For example, on the Italian side of the Isonzo Front there emerged songs in Italian (e.g., "Ho perso la voce sul Podgora" (I Lost My Voice at Podgora), "Monte Nero" (Mount Krn), etc.), but also in Friulan (e.g., "Il furlan" (The Friulian)). ${ }^{5}$ In later periods, these patriotic songs, including those created at the end of the war, such as the popular "La leggenda del Piave" (The Legend of the Piave), co-constructed 


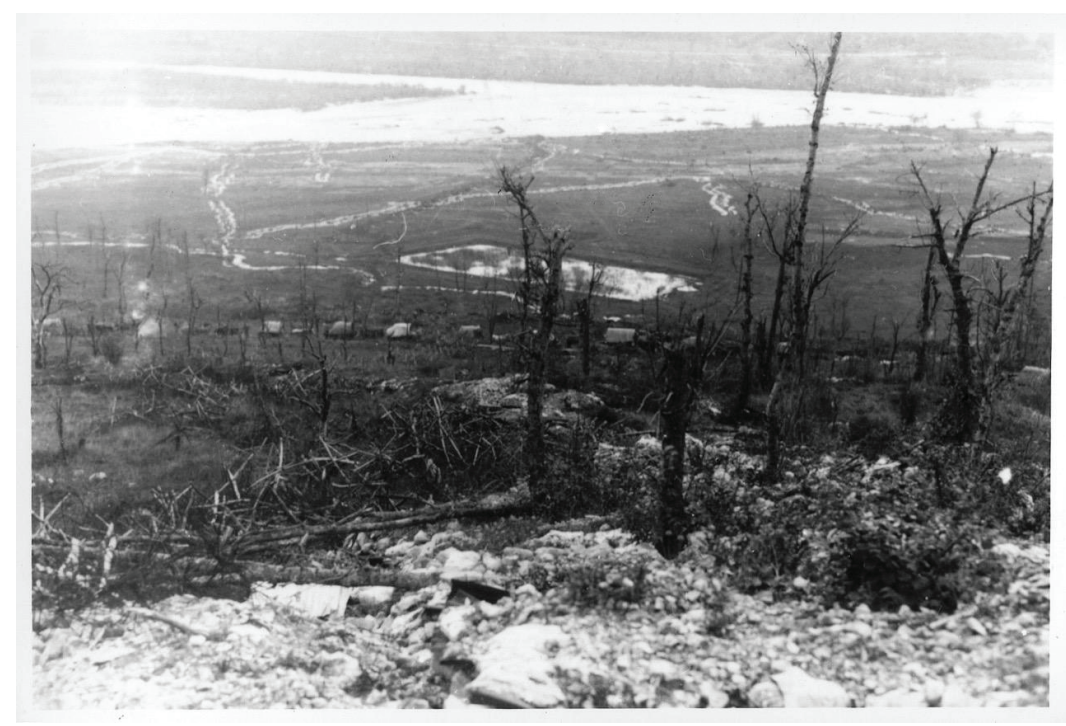

Figure 1. Tolmin valley: a view of the Soča and the abandoned positions of the first front line on the left bank after the successful breakthrough between Tolmin and Bovec. Courtesy of the National Museum of Contemporary History, Slovenia.

the collective memory of Italian citizens, nourishing "the myth of la Grande Guerra" (Pivato 2007: 131).

In the 1960s, however, a widespread "folk revival" countercultural movement emerged in Italy (Carrera 2001), which, following Antonio Gramsci, defined folklore as resistant expression of the subaltern and as narration of an alternative history (Castelli 2009). Ethnomusicologists such as Roberto Leydi publish the journal Nuovo Canzoniere Italiano (New Italian Songbook) to renew public interest in resistance songs. They also use anti-military songs to question the official narrative about the First World War. The clash of values in Italian society could be depicted by one such song, allegedly composed during the war at the Isonzo Front. The song "O Gorizia, tu sei maledetta" (O Gorizia, You Are Cursed) condemns the massacre in the battle for the town of Gorizia, which took place on August 9th and 10th, 1916. The song was written soon after the war, but found its way to the general public only in 1963, when the LP series Canti polotici e sociali (Political and Social Songs), edited by Leydi, released the anti-war collection entitled Il povero soldato (The Poor Soldier; Leydi 1963). However, when Nuovo Canzoniere Italiano received its own space in the program at the Festival dei Due Mondi in Spoleto in 1964, the singing 
of this song by Michele Luciano Straniero (and in particular the verses "traditori signori ufficiali / voi la guerra l'avete voluta / scannatori di carne venduta / questa guerra ci insegni a punir" (And you traitors, generals, officers, / You who strongly pushed for this war, / You're the butchers of our flesh for sale / This war teaches us to smite) provoked screaming in the audience about the glory of Italy. Consequently, Straniero and Leydi were reported to the police for publicly insulting the armed forces. ${ }^{6}$

"O Gorizia, tu sei maledetta" (O Gorizia, You Are Cursed) is a notable example of juxtaposition of an official glorification of the war and an anti-war popular discourse, which opposes both the war and the official discourse on it (Pivato 2007: 139-142). In Yugoslav and Slovenian history, songs from the First World War as well as those about it - not to mention ones with such a destiny as "Gorizia" - are rather absent. This is perhaps largely so because of entirely different political and ideological conditions. Nevertheless, Marija Klobčar, a researcher of Slovenian military folk songs (2007a), analyzed a few such songs from the First World War. She examined and confirmed or reinterpreted previous researchers' claims about these songs (2007b). Namely, Leo Hajek, who recorded the singing of Austro-Hungarian soldiers of various ethnic affiliations in the barracks in Judenburg in 1916 (Klobčar 2007a: 10; 2007b: 49), mentioned melancholy with regard to Slovenians' singing. ${ }^{7}$ According to him, their songs were neither combative nor rebellious (as in the Italian case mentioned above). Another musical phenomenon was observed by Matija Murko, a folk song researcher, in 1916. He mentioned a revival of older, allegedly lost (military) songs, as though special circumstances of crisis stimulated people to broaden their singing repertoire through the revival of older songs (Klobčar 2007b: 39-40). Nonetheless, their use for propaganda purposes should also be considered.

After the Second World War, in Yugoslavia, the songs that remained part of the singing repertoire were not labeled as First World War songs, but were detached from this context. This was largely the case because songs about the partisan movement and antifascist resistance of the Second World War dominated the scene (Hofman \& Pogačar 2017), and so the overall conditions for keeping the repertoire from the previous war alive were not favorable at all. The First World War was outside the scope of inquiry because another war was constitutive for the Yugoslav and Slovenian national consciousness of the time.

In light of these historical, geographical, ideological, and musical contexts, the recent emergence of the First World War as a topic in Slovenian popular music is a phenomenon without historical depth, which calls for an interpretation. As mentioned, an important change occurred with the public reappearance of the First World War in post-Yugoslav Slovenia. However, the musicians 
Figure 2. A group of AustroHungarian soldiers playing in the Tyrolean high mountain battlefield. Courtesy of the National Museum of Contemporary History, Slovenia.


Figure 3. A view of the town of Tolmin, 1917. Courtesy of the National Museum of Contemporary History, Slovenia. 
identified on the basis of dealing with this topic - and thus taken into analysis are connected with one particular place. Therefore, the interpretation below deals with the specifics of this connection in each of the cases. Before turning to this analysis, however, I present the place itself, its connection with the Isonzo Front, and its war heritage, as well as its musical past and present.

\section{THE PLACE}

I start by presenting the blossoming heritage industry in the Soča Valley, Slovenia, where Tolmin is also located. Then, I present specific features of manifestations of popular music in the town of Tolmin, which are important for contextualizing the musical works analyzed.

\section{The making of the Isonzo Front as local heritage}

In Yugoslavia, war-related heritage was largely limited to the Second World War. My interlocutor, an employee at the contemporary Institute for the Protection of Cultural Heritage of Slovenia, reproduced the instruction given in the 1980s by the institute's head about how to handle the First World War battlefields: "Take notes on that, but don't present it publicly. The time's not right yet." Yugoslavia took care of preserving military cemeteries and monuments from the First World War, but not the remains of the battlefields because the battles that were glorified were those of the partisan antifascist resistance. However, a few locals in the Isonzo Front area were quite familiar with the remains of its battlefields and had accumulated considerable knowledge about them already in Yugoslavia. First of all, local people came into contact with military objects and remnants of the war built in situ while searching for scrap iron to sell for extra cash. This practice had a long tradition, extending into the interwar period, when the area was part of Italy. However, after decades of sharing knowledge about wartime debris lying in the mountains, a few people developed a stronger interest in military artifacts and became collectors and connoisseurs of both wartime events in the area and the local terrain. These persons accumulated large collections of various items that they stored in their garages, basements, and barns.

The independence of Slovenia in 1991 is considered a turning point regarding the memory of the First World War. A few events in the early 1990s marked this turning point, all connected with the Isonzo Front. ${ }^{8}$ The previous individual collectors of military paraphernalia joined together in a few locally active as- 
sociations dedicated to preserving the heritage of the Isonzo Front; for example, the association 1313 was founded in 1990. A war museum was established in Kobarid in 1990, and in 1993 it won the Council of Europe Museum Prize. The book Plavi križ (Blue Cross) by Vasja Klavora was published in 1991 and was an immediate success. Gradually, especially in Kobarid, where the museum was also economically successful, an entire heritage industry developed, today employing a considerable number of residents.

Importantly, for the centennial of the war (between 2014 and 2018) local associations, museums, and other institutions involved in (war) heritage (e.g., the Kobarid Museum, the Walks of Peace Foundation in Kobarid, the Tolmin Museum, etc.) became increasingly active. Firstly, this is because the anniversary was a timeframe that (local) war enthusiasts were eager to celebrate. Secondly, by referring to the centennial, heritage institutions could obtain fresh national and international capital for heritage preservation. Thirdly, by referring to the centennial, the heritage industry could expand its business by attracting new and wider segments of audiences and thus attracting more visitors. Crucially for this article, in the Soča Valley an outcome of this invigorated heritage process is the ubiquitous discourse on the Isonzo Front and an increased public awareness about the war (heritage).

\section{Local musical life}

Here I shift from heritage to local manifestations of popular music, which helps contextualize the emergence of the Isonzo Front as a topic of contemporary musical works by a few artists. First of all, the considerable geography of cultural production in the Soča Valley should be briefly outlined. Namely, whereas Kobarid has evolved into the local center of the war heritage industry since the early 1990s, Tolmin, which lies sixteen kilometers away, has been the musical center of the valley for decades. There is a music school in the town, and quite heterogeneous musical life has strongly marked the town.

The first popular music band in Tolmin that I was able to identify ${ }^{9}$ was active under the leadership of Emanuel Leban after the Second World War. At that time, Italian popular music was locally praised, and it has been influential in the area since the interwar period. When the Sanremo Italian Song Festival started in 1951 (which was broadcast on radio and soon also on TV), local musicians paid attention to it, accepted it enthusiastically, and copied its current hits. By 1953 Sanremo had a local copy outside Tolmin called Beneška noč (Venetian Night). However, immediately after this event the performing musicians' leader, Ivo Medved, was interrogated by the local Socialist Alli- 
ance of Working People of Yugoslavia for performing Italian popular songs. At a time when relations between Yugoslavia and Italy were hostile because of the unresolved border issue, the band was accused of bourgeois behavior, of thinking that true democracy lay in the capitalist state, and of not properly understanding socialist democracy - all of this for playing popular Italian tunes (Tul 2002). Nevertheless, Italian songs, and particularly the festival in Sanremo, remained popular in the area and also among local musicians in the decades that followed. Indeed, this influence had a long-lasting impact on local musical taste, which was less oriented toward Slovenian folk pop (narodnozabauna glasba, otherwise the most popular music among Slovenians since the Second World War) and more toward various "western" styles. In different historical periods, local bands were therefore eager to imitate Italian hits, but also twist, Slovenian pop music (slovenska popevka), and later on rock and roll and rock.

Local production of music was principally oriented toward imitation and making covers of popular songs, although a few local musicians, starting with Emanuel Leban, also composed original songs. This changed in the 1990s, when local heavy metal bands completely reversed the logic of music-making by dedicating their entire repertoires to original compositions. This gradually also became a standard in other locally present musical genres; for example, rock and blues. However, this process of reorienting the young generation of local musicians from cover songs to original songs was marked by an additional reorientation. Namely, quite a few songwriters turned away from "general" topics to express something distinctively local in their song lyrics. The place where the musicians lived - their hometown and its surroundings - became the central scope of creative engagement for many of them. Lyrics in local dialect and the use of specific local expressions were another prominent part of their musical expression of local belonging. In addition, they also contributed a few reinterpretations of local folk songs.

In the mid-1990s, three bands distinctively marked this local musical turn: Medrje, Blêd Bend, and Tminski Madrigalisti. Nevertheless, this musical localism was not limited to these three groups, but to a certain extent also marked other contemporary performers in Tolmin and its vicinity: Abarigani Mzurisanaa, Projekt Sotočje, Rodoljubac, and The Štrudls. Moreover, the echoes of this turn into locality have remained present on the local musical scene until the present. Today, for example, the rap musician Iaria prominently continues it. In addition, Rodoljubac and Bakalina, which I analyze below, also preserve this legacy, and their interest in the First World War, which has recently become a prominent local topic, should also be understood in relation to this musical localism. 
Before I turn to concrete cases, I briefly present my explanation of this local musical phenomenon, which is an explanation relying on spatial analysis. As I discussed elsewhere (Kozorog 2010, 2011), in the early 1990s something crucial occurred on the youth scene (and the related music scene) in Tolmin. Namely, along the Soča River two venues were established by young people themselves, which enabled them to freely express their enjoyment of place-based autonomy. For young people, the venues crucially reorganized local space and became the "background" (Hirsch 1995: 3-4) for a completely new sense of place. The venues introduced a new angle from which young people could perceive their hometown, which from their point of view was transformed from a dull "hole" into a place marked by distinctive venues located in aesthetically pleasing locations along the river. For example, the song "The Tmin's [Tolmin] Summertime Rock'n'Roll" by Blêd Bend enthusiastically describes the two venues and the freedom enjoyed there by the young. Young people's autonomous production of place (i.e., the venues of making and organizing) and space (i.e., practicing the town, sensing it, positioning it in broader geographies, etc.) stimulated its local identification, and consequently the expression of this identity in music. In addition, musical representations of place also contributed to its production; namely, through a specific description of the place in young people's own terms (cf. Cohen 1995).

In addition to enjoying the venues themselves, local young people were eager (and perhaps proud) to host like-minded people from elsewhere, which led to an artistic festival called Sajeta in 1998. Its aim was to create collaborations between local and foreign artists by hosting the latter. This festival is still being held today, ${ }^{10}$ and part of Bratko Bibič's project discussed below was produced within the framework of this festival.

\section{THE OPTIONAL, THE SENSITIVE, AND THE STUDIOUS}

This section presents musical works dedicated to the Isonzo Front, composed by Rodoljubac, Bakalina, and Bratko Bibič. I conducted interviews with the musicians, asking them about the circumstances that led them to compose their music, about the musical components and textual part of their musical works, about their personal relation to the war, about their relation to the Soča Valley, and about their collaboration during the centennial of the war. ${ }^{11}$ The following subsections present each performer and relevant compositions as well as the circumstances of their creation. I also point out the musicians' attitudes to the place. Then I conclude by referring to differences in ways of knowing the place, which stimulated three different portraits of this locally fought war. 


\section{"A Farewell to Arms"}

The band Rodoljubac performs garage rock and roll with elements of heavy metal music. The band was formed in 1996 (I was among the founding members of this band) as part of the aforementioned locality-oriented Tolmin music and youth scene, and so far it has released five albums. The principal characteristic of the band is parody, which is primarily directed towards popular music genres and the music industry, but also broader society and the band itself. Their song examined here is "Zbogom orožje" (A Farewell to Arms), named after the novel by Ernest Hemingway, which contains references to the Isonzo Front.

"A Farewell to Arms" - recorded in 2015 and released on the album Rodoljubac in 2016 - was not the band's first song dedicated to history. In 2008, the band released the album 1713 , containing a song with the same name, which refers to (the year of) the Tolmin peasant rebellion. As a matter of fact, history is rare among the band's themes, but when it is there, it is a place-bound history. When I asked about the motive for writing a song about the First World War, I received the following explanation:

Rock bands often have epic or historical songs, but they usually say stupid things. For instance, bands praise invented battles or battles from I don't know where, whereas us, we live here in an area where still, every day you can see consequences of the war, and we therefore decided, first, to work on the Tolmin peasant rebellion of 1713, and then - what else could we work on about Tolmin? - well, the First World War! ... After so many years of making music, sometimes you don't find the right inspiration. So, maybe we saw other bands singing about wars, ${ }^{12}$ yet completely empty, so we said, why not write a song about our surroundings because we really have something to sing about. (Davor Mrak) ${ }^{13}$

As is the case with quite a few residents of the Soča Valley, one of the band members has demonstrated a greater passion for the history of the Isonzo Front, so he wrote the song's lyrics. Yet the decision to represent the war was a collective one. One of the band members explained to me that the war heritage has become an integral part of the local environment, and so "everyone who's living in this area has an attitude toward the war, although everyone has a different one". Another band member, Davor Mrak, whom I interviewed, described to me the process of finding consensus about the song. From his narration, it follows that the song is more an outcome of a certain sense of place, containing knowledge about the war, nowadays broadly shared in the Soča Valley, than it is a result of a single member's (i.e., the lyricist's) passion for the Isonzo Front. 
After writing the lyrics, it took some time before the music was composed and the song finished, recorded, and released. The band decided on a heavy metal style, rather than rock and roll, because slow and heavy riffs seemed more appropriate for the war theme. Although the decision to produce the song and the process of recording it was detached from the centennial of the war, the centennial nonetheless influenced its recording and release. Namely, when Rodoljubac was in the recording studio in 2015, it turned out that the centennial of the date when the Kingdom of Italy declared war on Austro-Hungary - which coincided with the opening of the Isonzo Front - was quickly approaching. This convinced the band to finish the song, which was then released on YouTube on May 21st, 2015, two days before the centennial. Hence, the anniversary was the trigger that convinced the band to release this song before all the other songs from the record. The song was then released on CD together with others a year later.

The song's lyrics are set around the events that led to the collapse of the Isonzo Front. They say that Mounts Škabrijel, Batognica, and Krn were a "bloody thorn" for the combatants, but then the "miracle of Kobarid" happened, as the battle between October 24 th and 27th, 1917, is colloquially called, which forced the Italian army to withdraw from the Soča to the Piave River. It also mentions the role of the renowned Lieutenant Erwin Rommel in this battle and his breakthrough over Mount Kolovrat above Tolmin. However, during the recording session, a dispute broke out in the band because one member thought that the song was one-sided, ridiculing the Italians. In the studio, the band even wrote an alternative, more balanced version of the song, but then nevertheless decided to keep the first version. The reason for this was the argument that the Soča Valley was Austro-Hungarian at that time and hence, at least in the band members' perception, even today locals praise the Austro-Hungarian side more than the other side in the war.

Nonetheless, the song portrays the war in what may be politically incorrect terms: "On the Austro-Hungarian side our grandfathers were slaughtering / Borojević was their general / Many gave their lives / Instead of lying in their beds at home with their women." The text is in local dialect, but the refrain is sung in broken German: "Hilfe mich o meine Mutter, warum wurde ich ein Kannon Futter" (Help me, oh, my mother, why am I cannon fodder?). When I asked Davor Mrak where this phrase came from, I received the answer:

The war was tragic, but the song contains some of our typical dark humor. That German soldier up there wouldn't ask himself this in such a way. Kannon Futter sounds a bit funny in this context. We kept it to soften everything a little bit. A person listening to this song should know us to understand why we present things not too seriously. 




Figure 4. Austro-Hungarian military cemetery St Lucija, now Most na Soči. Courtesy of the National Museum of Contemporary History, Slovenia.

According to him, the gallows humor that the band cultivates is actually part of local character, which might have its roots even in the events of the First World War:

The sense of humor we have in Tolmin is specific and could be an outcome of historical events in this area. The conditions were certainly hard and people had to adapt in order to survive. This is perhaps why a more ironic and dark sense of humor developed here, which is characteristic of people in these surroundings. For the people the war was a huge trauma and it changed the course of life enormously, we cannot even imagine it, so they had to patch up the situation somehow, and I think our character has been shaped by those wartime events.

One can observe in Rodoljubac's presentation of the war both respectfulness (the song finishes with the following lines: "Many [soldiers] gave their lives / In the Soča Valley forever they remained") and an unburdened, distant, and optional view of the wartime events. Whereas the lyrics maintain a distance from how the war was felt by its contemporary participants (soldiers and civilians), it reproduces a present local perspective on the war, which is usually limited to familiarity with the major historical events in the valley (e.g., major battles). 
Moreover, in addition to reproducing the local perception of the war, the band also remained faithful to the characteristics of the heavy metal genre and especially its own (again interpreted as local) expression of gallows humor. The band's representation of the war could therefore be summarized as an outgrowth of broader contemporary events and discourses in the Soča Valley, where especially in the recent centennial years the Isonzo Front has become omnipresent - that is, a part of the local social atmosphere from which Rodoljubac has always drawn its inspiration.

\section{"The Letter"}

The two performers of the duo Bakalina, which has released four albums since 2009, are: Renata Lapanja on accordion, and the vocalist and songwriter Jani Kutin. They live in two mountain villages around Tolmin. Bakalina performs original chansons, resembling Slovenian traditional folk songs. The lyrics, written by Kutin, are in the local dialect, depicting local rural life, and in many cases containing a moral (sometimes with plenty of humor and irony) about the destructive ways of contemporary living in contrast to (in the songwriter's view) the more righteous life in the past. Before establishing the duo, Kutin was a member of quite a few musical collectives and projects, among them The Strudls, who were among the early local bands reflecting on local matters in the local dialect. Kutin has written two songs dedicated to the Isonzo Front: "Rdejč ruob" (Red Rim), named after the mountain in front of his home village of Cadrg, where there was a battlefield during the First World War, and "Pisma" (The Letter), which portrays a soldier writing to his mother.

There is a stark contrast between these songs and the one by Rodoljubac. There is not merely a musical difference between the heavy guitar riffs and gloomy melodies of the accordion, but also the point of view of the narrator is entirely reversed: whereas Rodoljubac provides a distant gaze of a contemporaneous native observer of historical local events, Bakalina builds on a personal impression of the war by a war participant: a soldier. In "Red Rim", released in 2011, the course of a soldier from home to the Isonzo Front is described. Observing human tragedy, this soldier loses his soul: "He cried out loudly / But not because of pain / Much more because of sorrow. / What beautiful was, died / It only was a memory / Darkness fell on eyes." Although the narrator describes the soldier's states of being as observer, a feeling of intimacy is provided in order to produce identification by the listener with the soldier's personal tragedy. Even more personal is "The Letter", released in 2016, where the listener hears a confession of a soldier to his mother. In this song, the soldier's soul has 


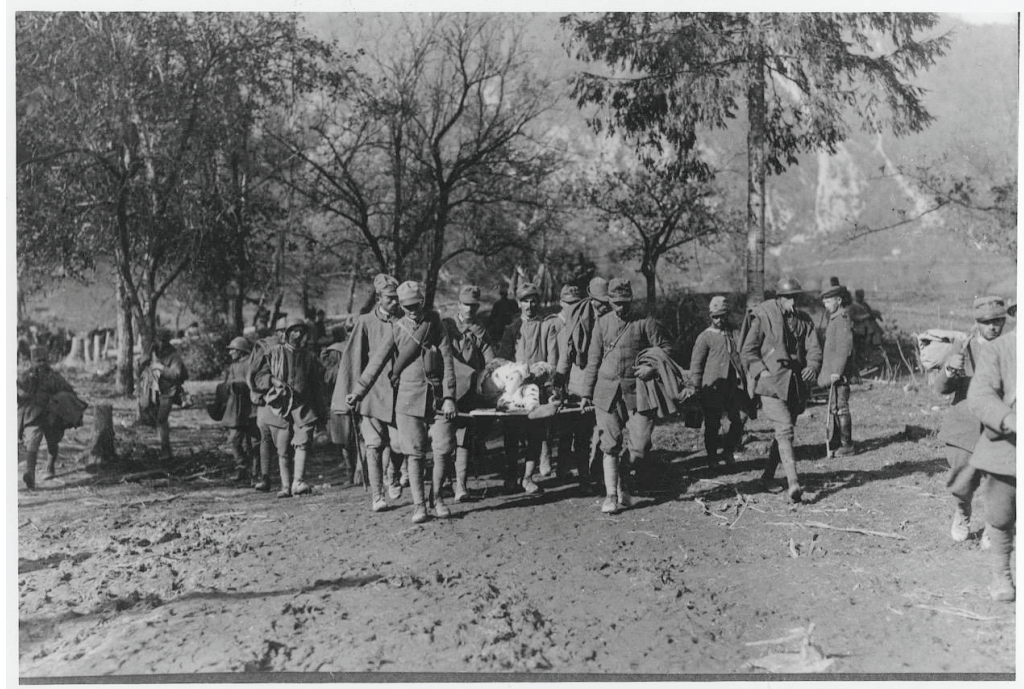

Figure 5. Italian prisoners of war in Zatolmin. Courtesy of the National Museum of Contemporary History, Slovenia.

died by abandoning everything human that his mother taught him: "Don't wait for me mother / I don't find peace anymore / I've died inside. / I only beg you mother / Pray for all those / Who cannot go home." The refrain is the soldier's repetitive yearning: "I'd like to go home." This phrase, which is backed up by a male choir on the recorded version, affects listeners' compassion.

This specific mode of depicting the war as a human and personal tragedy is rooted in the songwriter's experience of remnants of the war. Kutin is a farmer, the successor at a family farm, who knows the area around his home village quite well. He also remembers stories told by his grandfather about wartime events in the vicinity, and he recalls his first contact with remnants of the war: "My brother and I have been collecting antiques since we were little kids, including military paraphernalia. We found one whole gun, down under a rock, when we were around ten." As a child he explored the nearby slopes, gorges, mountains, and abandoned households. In addition, collecting remnants of the First World War was also present in the family:

Two of my uncles were collecting. One still collects a bit, but he never had a private museum or anything, the other is already dead, and was addicted to this [practice], he was also unmarried, and sadly he died because of this hobby. A grenade [that he found in the ground] exploded. 
After this accident, Kutin gave up collecting military items and instead dedicated his collection to farm implements:

As kids we were very interested in the war, well, in the remnants of the First World War. ... But as a kid you don't think what war is in reality. ... Other people my age were collectors too. Young people in the village of Zatolmin have many home collections. I still know many who go out to dig with metal detectors every day, up and down. They dig out artifacts and that's their greatest pleasure. And I understand this less and less.... At the same time, I think we're talking far too little about the suffering and consequences of the war. ... Well, I've always felt this very much. Of course, the whole Tolmin area is impregnated with this feeling, which hasn't entirely left this valley in a hundred years. You can't dismiss it as if nothing happened, if you've got at least some sensitivity. So, in my opinion the songs I've written emerged very spontaneously, as a confession, so that I gave away my feelings about the war, without wanting to dramatize it.

This musician has had intense relations with war-related phenomena in the area. He explored military structures and listened to stories about wartime events as a child, he has been observing and experiencing local collecting practices and their consequences, he has been engaged with the local landscape, which is not only used for farming, but is also the bearer of the memory of a difficult history, which makes him think about the wartime events that took place there, and he also senses the remnants of the war as still radiating a specific feeling of wartime suffering (cf. Navaro-Yashin 2012). Importantly, however, Kutin is a farmer, who regularly works outside, where he is in direct contact with the landscape where the war took place. For example, the mountain after which he named his first song about the Isonzo Front rises high opposite his house:

It's a big mountain, especially when seen from Čadrg. It's paramount. And if you look at it all your life and if you're connecting it with the war, you can't overlook it. ... And it helps imagine what a severe environment they [the soldiers] were pushed into. Those cliffs, freezing, in a condition without hope, and besides all this they had to fight. Well, it was really bad.

His second song was also stimulated by his sense of place. He was inspired while visiting the Church of the Holy Spirit in Javorca, in the Tolminka Valley, just below his home village. It was built during the war by Austro-Hungarian soldiers, just behind the frontline at the mountain that Kutin used as a motif in his first song: 
I remember when I came to Javorca as a kid. This church means a lot to me. Maybe because it's the church closest to our village and so every time there was a mass we went there to attend mass. ... But I've always felt ... I experienced this place very strongly. Someone will look only at the architecture, and yes, it's a very beautiful church. But you can't overlook all those names [of dead soldiers, which are engraved on the church's walls]. And although they aren't buried there, their names are so strong. ... Really, I see Javorca every time I'm at the edge of the village. It's such a prominent spot, which always makes me ... And when I was writing this second song, 'The Letter', I remember exactly the moment when I got the idea for this song. I was cutting grass below the village, from where you can see Javorca, and I was cutting, and this melody just appeared, and the refrain 'I'd like to go home', and then when I sang the first two lines when I started to write it down, the song was so strong that tears came to my eyes. I knew that that was it, because such moments don't come so often that you feel one song so strongly already when you're creating it. It came directly from the place.

Because this specific location inspired the song, the songwriter demanded that they record it in Javorca, which was a special experience, as he recalls: "We felt the presence of those soldiers while recording". The decision to record it at Javorca was also made on the basis of the duo's previous musical experience of this place. Namely, in 2014, the accordion player Renata Lapanja, again on the basis of her personal sense of the place, held a concert there entitled Benevolent Concert for Peace. This concert was partly dedicated to the centennial of the war, but organized spontaneously, not as an official celebration of the anniversary. ${ }^{14}$ On this occasion, Bakalina performed "The Letter" for the first time: "It was a very special feeling. ... And that was one of the first events dedicated to the centennial" (Jani Kutin).

Nonetheless, Bakalina's songs were not composed because of the centennial, but in spite of it. The primary motivation for the duo to dedicate their works and concerts to the memory of the war came from their personal sense of the local landscapes as material preservers of the suffering in the region in the past (cf. Saunders 2001). The songs thus sprang from a specific perception of places that were settings of wartime events. At the same time, the duo continues to carefully reflect on the places where these songs are performed. For example, when invited by heritage agents in Kobarid to perform "The Letter" at the main event marking the centennial of the Isonzo Front, Bakalina refused to take part because the event was based on a reconstruction (or performance) of a historical battle: 
We have a poor awareness of today's wars. They are different, but they exist, and people suffer the same. ... Why collaborate in an event where thousands of euros are spent to staging a hundred-year-old battle? Man, nearby in Gorizia, we have I don't know how many thousands of refugees in catastrophic conditions. Nobody is aware of that, and nobody helps, and it's getting worse as I hear. For a while, there was compassion, but now it goes on without anyone saying anything. So, we refused this performance for this reason. (Jani Kutin)

\section{Javorca: Resurrection}

Bratko Bibič is a musician that has been subverting Slovenian popular music and culture since the 1970s. At that time, he established the avant-garde band Begnagrad, which partly relied on the Alpine folk-pop musical culture, overturning it with rock-in-opposition and jazz elements. The band was controversial for using what was at that time the allegedly "out of fashion" accordion in the field dominated by electric guitars and progressive composition (cf. Bibič 2014). As an accordion player and composer, Bibič then also became internationally active through collaboration in the rock-in-opposition band Nimal and the accordion "supergroup" Accordion Tribe. Moreover, as a soloist he combined music and other artistic forms. He dedicated a piece of work to Slovenian film heritage, combining archival research, film montage, and composition. In addition, as sociologist and philosopher, he has also been working as a researcher, an important field of his enquiry being urban politics and the social production of space (Bibič 2003).

His work on the Isonzo Front also combines archival and conceptual research, musical composition, and interlacing of artistic forms. The work, dedicated to the aforementioned church in Javorca, deals with the rear areas of the front, where during the war everyday life - music and entertainment included was established. The Church of the Holy Spirit was built in 1916 by AustroHungarian soldiers (i.e., during the war for a spiritual purpose), and today is regarded as a unique piece of Secession architecture in the Slovenian Alps. It stands in Javorca, a low ridge in the Tolminka Valley (close to the source of the Tolminka River), surrounded by a chain of high mountains. Bibič, similarly to Kutin, describes the church and its location as "suggestive". It has a unique architecture, also because the names of dead soldiers are engraved on wooden panels, which hang from the walls inside the church, symbolizing a memorial book. Bibič recalls that these names already fascinated him as a child. 


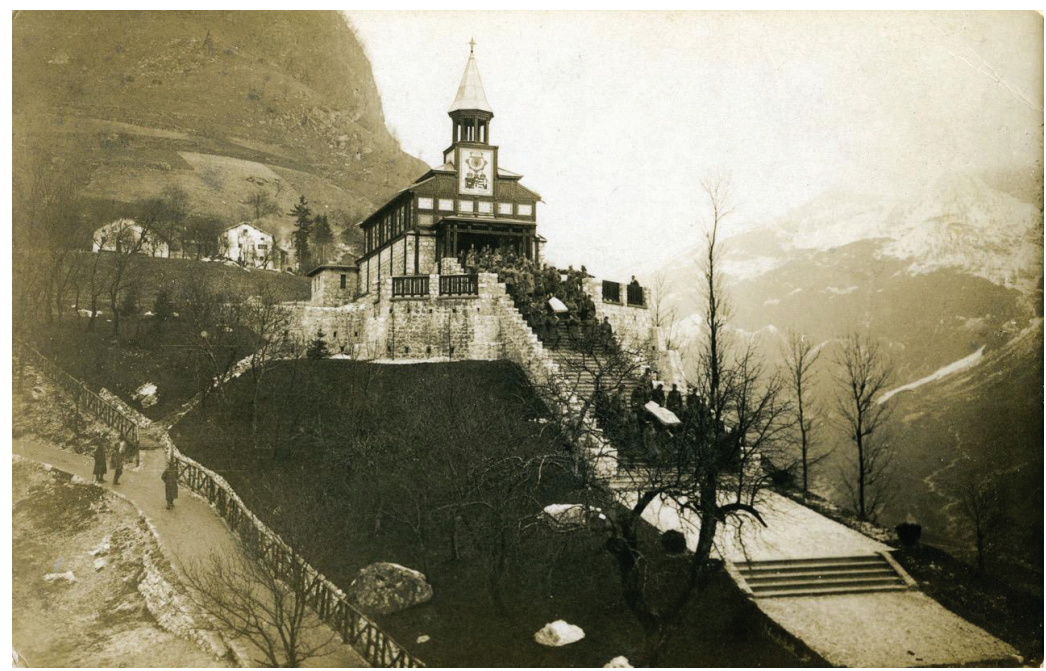

Figure 6. Holy mass for fallen soldiers in the Church of the Holy Spirit on Javorca. Courtesy of the National Museum of Contemporary History, Slovenia.

His work on the project Javorca: Resurrection started in 2009, and has gone through several phases. Initially he wrote a script for a multimedia performance, which turned into a synopsis for a film. Because of a lack of funds to produce a film, he composed a cantata, performed at the Cerkno Jazz Festival as Javorca: Quasi una cantata (Javorca: Almost a Cantata) in 2010. He then developed it into the multimedia project Javorca: resurekcija (Javorca: Resurrection), which was performed in the church at Javorca as part of the Sajeta festival in 2016.

Bibič grasps the church (or what it represents) in its complexity; that is, by relating history, contemporary heritage regimes, and the dead, preserved in the names on the church's walls. The core protagonist in the initial script of the project is a child, whom the Good Soldier Švejk leads through an Alpine area, wittily called a "natural history park". The script presents this "protected area" as subordinated to flourishing regimes of heritagization and touristification. At the same time, it is a setting for a circus, which during the war toured the rear areas of the front. Its protagonists are all dead today, but they continue to perform for the park's visitors, and thus Švejk and the child enjoy their show. The perspective on the "protected area" is thus an uncanny combination of entertainment and piety.

Although the artist relies on the figure of a child because it represents curiosity, there is also another, personal reason for this. Bibič is a native of 
Ljubljana, but his mother a native of Zatolmin, a village between Tolmin and Javorca. Because both of his parents worked in education, he remembers that in the 1960s the family spent entire summers in Zatolmin, where, in addition to enjoying the long school vacations, he was involved in his relatives' farming. He recalls that his first contact with the Holy Spirit Church, eight kilometers distant from Zatolmin, probably took place as part of this vacationing, when the family stayed in a lodge in the mountain pasture, located near a shooting range in Javorca. More important, however, was an experience in the late 1960s. When he was about ten years old, and as part of his ordinary exploration of the area at that time, he ventured from Zatolmin into the Tolminka Valley alone. This expedition turned into a powerful childhood memory, which he describes as follows:

You don't clearly recall many things from your childhood. They have to be powerful. I will remember for my whole life how I stepped out ... That was the time when the surroundings [of the Church of the Holy Spirit] were overgrown and the church was in ruins. It was in its worst condition ever. ${ }^{15}$ I probably took a shortcut towards the church. I remember when I stepped out from the bushes, and I was standing right in front of that big staircase that leads towards the church. And the stairs were partly in ruins; they were broken, ruined, and overgrown with brambles. But on those stairs there were some twenty snakes sunning themselves. Adders, vipers, who knows what. I stepped right in front of them. So, I have this memory: that staircase, which is monumental, especially for a small kid, partly ruined, and about twenty curled up snakes on it, sunning themselves.

This powerful experience is one thing he remembers as crucial for his further investigation of the war. The other thing he mentions is his fascination "with the whole ambient of the First World War, which was then [in his childhood] completely untouched or, in other words, nobody was occupied with that. For a boy, war is often fascinating, and I was fascinated by that complex of bunkers in the Tolminka Valley and other remains there". Like Kutin, he too mentions his own finds of military objects close to the house, where he was on vacation.

Yet, unlike Kutin, he was living elsewhere, detached from the local landscapes. His later dealing with the place has thus primarily been contemplative. He has been reflecting on his own experiences of the remnants of war as well as on the war itself largely through philosophical, sociological, and artistic prisms. His treatment of the war, for example, reflects on various layers of space (i.e. material, symbolic, and experiential), which he was familiar with from his previous research on the production of space and urban process (e.g. Bibič 2003). This research provided him with solid conceptual tools for 
thinking about what he calls "urbanization of the Alps through the war". In this regard, he describes the war as bizarre because destruction went hand in hand with building infrastructure in previously undeveloped areas (which were commonly understood as "natural"), like the Alps. Thus, for example, the Austro-Hungarian army built the road connecting Zatolmin and Javorca (i.e., the one that Bibič used for childhood exploration) for the purpose of war; that is, for supplying the front.

At the same time, Bibič's composition deals with many other aspects of the war. Thus, for example, he contextualizes the particular location in relation to broader contemporary social processes, especially by referring to avant-garde artistic movements - futurism and dada - occurring not far from the frontline between Italy and Austro-Hungary. Again, he received an impulse to investigate these aspects of the First World War from his previous research, this time on Walter Benjamin (Bibič-Faninger 1991). Namely, Benjamin's essay titled “The Work of Art in the Age of Mechanical Reproduction" refers to Marinetti's glorification of war in order to present ideas on aesthetization of war and politization of art. Bibič uses various outstanding quotes (e.g., from Hemingway's A Natural History of the Dead, which states: "They had beautiful burying grounds in the mountains, war in the mountains is the most beautiful of all war...") as well as archival audio materials: recordings of singing soldiers (e.g., from Judenburg); part of Stravinsky's L'histoire du soldat (The Soldier's Tale), which he wrote in Switzerland during the war; and a cantata dedicated to the Soča River from 1916, which the Slovenian composer Hugolin Sattner based on a famous poem by the Slovenian poet Simon Gregorčič. Among other narratives, the names on the church's walls are recited in the composition. The apparatus that Bibič developed to interconnect historical events, the place, built and natural environments, personal memories, philosophical references, metaphorical derivations, and so on, is thus much too complex to allow adequate reproduction here. What I would like to highlight, however, is his ways of knowing the place, which on the one hand contain memories of personal experiences of the place, and on the other various theoretical and artistic approaches to comprehension of place and space.

After Bibič publicly presented his work about Javorca, his cousin reminded him that he had been saying for a long time that he would compose a cantata composed of the names on the church's walls. The fact that this artistic impulse coincided with the centennial was largely a coincidence, as he wittily remarks:

I started the project in 2009 simply because I received a grant from the Slovenian Ministry of Culture. ${ }^{16}$ Marinetti wrote the futurism manifesto in 1909. Hence, if any centennial coincides with my project, is the 
centennial of futurism. [Laughs] Merely a coincidence. ... Whereas in 2016, when I made the last version, it was coincidently a centennial of Cabaret Voltaire and dada. [Laughs].

In 2016, however, when national and local authorities and heritage promoters celebrated the centennial of the church in Javorca, the organizers of the Sajeta festival in Tolmin used this opportunity to invite Bibič to develop his artistic work as part of the festival and its international project, entitled Echoes from Invisible Landscapes. The performance of Javorca: Resurrection in the church in Javorca was very ritualistic, ${ }^{17}$ which was another of Bibič's comments on and subversion of the multitude of rituals appearing locally for various centennials of the war.

\section{CONCLUSION}

I have presented three recent Slovenian popular music works dedicated to the Isonzo Front. Musically they do not share many things; they are aesthetically and conceptually very different from each other. Doubtlessly, the commitment of musicians to their own aesthetics and concepts played an important role in their music-making and informed the modes of representation of the selected theme. However, more than to aesthetics, I have paid attention to the procedures of establishing the First World War for their theme because this has hitherto been largely neglected in Slovenian popular culture. Specifically, I was concerned with the role of their knowing a particular war-related place in their construction of the theme. Namely, each of the musicians presented is connected to the Tolmin area in one way or another, which is on the one hand marked by rich local musical life and on the other by gradually intensifying heritagization procedures and centennial celebrations. Most of the members of Rodoljubac and Bakalina live there, whereas Bratko Bibič experienced this place as a child. However, because their practice and their experience of the place vary, my core question is whether differences in the ways of knowing a place engender differences in representations of that place and its history.

The cases presented demonstrate that four ways of knowing the place contributed to the musical works examined. In the case of Rodoljubac, most of the members were not especially engaged with the war, although one of them showed a greater interest in the local legacy of the war. They have primarily been involved in common discourse on the war, which nowadays produces a specific local social environment that - increasingly during the centennial years - cultivates a narration about the involvement of "their" place - that is, 
the place they identify with - in the war. The war has become an integral part of the contemporary social process in the town of Tolmin, where its residents superficially know its history, but are constantly exposed to the present manifestations of war, which find their place in public events and mass media reports, but also in everyday conversations by fellow residents. However, usually the residents know only a few things about the war (e.g., the major events), which is reflected in the representation by Rodoljubac. As a band that has devoted some of its works to locally important topics, it also decided to dedicate part of its work to a war fought locally, which it represents by the major battle that led to the collapse of the Isonzo Front.

Quite differently, Jani Kutin from Bakalina investigated the local landscapes as a child and has remained connected to them as a farmer. He perceives the landscape as full of remnants from the war (i.e., objects in the ground, monuments like Javorca, and ruins), which he primarily associates with human suffering. He contemplates these landscapes as though they are alive, as if the material world he is in daily contact with keeps on preserving the experience of those that went through the tragedy of the war a hundred years ago. His everyday observation of - and movement through - such landscapes thus stimulated him to produce words and a melody for a song representing the presumed inner feelings of a soldier.

In a way, Bratko Bibič's direct experience of the place and its landscape is similar to Kutin's, yet his experience also contains a temporal and spatial distance. Moreover, although childhood memories stimulated him to return to the place as an acknowledged artist, he also relies on other ways of knowing the place; namely, on various approaches to studying it. Through these approaches, he loads upon the place many layers of meaning, some referring to theoretical conceptualizations of place and space, and others to artistic metaphors he has developed. His Javorca: Resurrection is a meshwork of history, memory, and the present oversupply of heritage regimes, in which tourism plays an integral role. This representation of place and the war also critically reflects on the contemporary processes of place-making, in which the dead are reanimated to serve the demands of today's economy for the production of alluring places.

The cases thus confirm the thesis behind my inquiry that different ways of knowing a place have played an integral role in engendering different musical representations of the place and its wartime history.

However, let me conclude with another, less relevant inquiry of my investigation - that is, musicians' collaboration in the centennial celebrations. As already mentioned, such celebrations are part of the present experience of the place because policymakers have recognized the centennial as an opportunity for branding the place. As also mentioned, this social atmosphere was in one 
way or another involved in the creation of three musical works. However, were the musicians also involved in the celebrations? My interlocutor from Rodoljubac says that this was not the case because policymakers perceive the band as a representative of local underground culture. Hence, they will most likely remain unnoticed by such agents. Bratko Bibič, on the other hand, presented Javorca: Resurrection as a centennial event. However, this event was held by an alternative culture organization (i.e., the Sajeta festival), which made possible a reflexive and critical contextualization of war anniversaries. Bakalina was invited to perform as part of a central centennial event whose core component was a battle. The organizer invited the duo in order "to soften the experience of the battle a bit". For ethical reasons, Bakalina refused to participate, although it has been involved in other, less explicitly militant, centennial events. Indeed, these artists are attentive to the ways they present their work dedicated to the war. They dealt with ethical questions already while composing their works, and they are well aware of the moral ambiguity of contemporary celebrations of the centennials.

\section{NOTES}

1 The article is based on research carried out for the research project titled Heritage of the First World War: Representations and Reinterpretations (2016-2018), funded by the Slovenian Research Agency (No. J6-7173). For more information about the project, see Jezernik \& Fikfak 2018.

2 Ethnologists, ethnomusicologists, music folklorists, anthropologists, and other researchers have shown on a number of occasions that the distinction between popular and folk music is problematic. I use it loosely; that is, in its conventional sense, to distinguish between music made with reference to mass media (i.e., popular music) and music performed and transmitted detached from the mass media context (i.e., folk music).

3 See https://neubauten.org/en/lament, last accessed on 24 September 2018.

4 The river is known as the Isonzo in Italian and the Soča in Slovenian. It rises in the Julian Alps in Slovenia and empties into the Adriatic Sea in Italy.

5 Itinerari della Grande Guerra - un viaggio nella storia (see http://www. itinerarigrandeguerra.it/it/29640/Le-canzoni-della-Grande-Guerra, last accessed on 24 September 2018).

6 Canzoni contro la guerra (Anti-war songs) (see https://www.antiwarsongs.org/canzone. php?id=47\&lang=it, last accessed on 24 September 2018).

7 The Habsburg Empire established permanent recruitment districts already in 1771, which led to ethnical and language uniform regiments, "which facilitated and at the same time constrained group singing" (Klobčar 2007b: 39). 
8 This also partly explains why, in the public imagination in Slovenia, the First World War is associated above all with the Isonzo Front and not with other battlefields of the time.

9 For more information about the history and social aspects of musical production in Tolmin, see my bachelor's thesis (Kozorog 2002), inspired by anthropological works on the complexity of local musical life (Finnegan 1989; Muršič 2000).

${ }^{10}$ In the interest of full disclosure, I was the festival's program curator from 2002 to 2010.

11 Three ethnographic interviews and additional conversations with those involved were carried out in July 2017.

${ }^{12}$ I can mention two other examples of the First World War representations in heavy metal music. In 1995, the Colombian metal band Neurosis released an album named after a Western Front battlefield: Verdun 1916. Allegedly, at the same time as Rodoljubac (but independently), the Slovenian heavy metal band Requiem from Ljubljana released a song dedicated to the First World War.

${ }^{13}$ I have mentioned the names of the interlocutors with whom I conducted official interviews. I refer to other members of Rodoljubac as to band members.

${ }^{14}$ Increased awareness of the war in the area is a social context that, as in the case of Rodoljubac, should not be neglected.

15 The church was renovated in the early 1980 s.

16 The grant was not defined by the content of the artistic project.

${ }^{17}$ For example, Bibič involved spatial components in the performance. The composition was performed by four musicians in the church when no audience was present. In real time, it was - together with mixed-in texts and photograph animations - audiovisually streamed via satellite to a large screen for the audience at the confluence of Tolminka and Soča Rivers. The performance of the musical work was thus connected with the source of the Tolminka River, where the church was built during the war, while the work's reception found its place at the river mouth, where the battles took place.

\section{REFERENCES}

Bibič, Bratko 2003. Hrup z Metelkove: tranzicije prostorov in kulture v Ljubljani. [The Noise from Metelkova: Transitions of Spaces and Culture in Ljubljana.] Ljubljana: Mirovni inštitut. Available at http://www2.mirovni-institut.si/slo_html/ publikacije/pdf/MI_politike_hrup_z_metelkove.pdf, last accessed on 24 July 2018.

Bibič, Bratko 2014. Harmonika za butalce: ulomki iz življenja nekega glasbila. [Accordion for Dummies: Fractions from the Life of a Musician.] Ljubljana: Beletrina.

Bibič-Faninger, Bratko 1991. Elementi za branje del Walterja Benjamina. [Elements for Reading the Works of Walter Benjamin.] Anthropos, Vol. 23, No. 4-5, pp. 81-97. 
Carrera, Alessandro 2001. Folk Music and Popular Song from the Nineteenth Century to the 1990s. In: Zygmunt G. Baranski \& Rebecca J. West (eds.) The Cambridge Companion to Modern Italian Culture. Cambridge: Cambridge University Press, pp. 325-335. https://doi.org/10.1017/CCOL0521550343.018.

Castelli, Franco 2009. "Compagni dai campi e dalle officine": Appunti sul canto sociale e politico in Italia. Quaderno di storia contemporanea, Vol. 46, pp. 119-169. Available at http://www.isral.it/web/pubblicazioni/qsc_46_06_castelli.pdf, last accessed on 24 July 2018.

Cohen, Sara 1995. Sounding Out the City: Music and the Sensuous Production of Place. Transactions of the Institute of British Geographers, Vol. 20, No. 4, pp. 434-446. http://dx.doi.org/10.2307/622974.

Connell, John \& Gibson, Chris 2003. Sound Tracks: Popular Music, Identity and Place. London \& New York: Routledge.

Feld, Steven 1982. Sound and Sentiment: Birds, Weeping, Poetics, and Song in Kaluli Expression. Philadelphia: University of Pennsylvania Press.

Finnegan, Ruth 1989. The Hidden Musicians: Music-Making in an English Town. Cambridge: Cambridge University Press.

Hirsch, Eric 1995. Introduction. Landscape: Between Place and Space. In: Eric Hirsch \& Michael O'Hanlon (eds.) The Anthropology of Landscape: Perspectives on Place and Space. Oxford: Clarendon Press, pp. 1-30.

Hofman, Ana, \& Pogačar, Martin 2017. Partisan Resistance Today? The Music of the National Liberation Struggle and Social Engagement. In: Miha Kozorog \& Rajko Muršič (eds.) Sounds of Attraction: Yugoslav and Post-Yugoslav Popular Music. Ljubljana: Ljubljana University Press, Faculty of Arts, pp. 21-39.

Jezernik, Božidar \& Fikfak, Jurij (eds.) 2018. Cultural Heritage of the Great War. Traditiones, Vol. 47, No. 1. DOI: 10.3986/Traditio20184701.

Klobčar, Marija 2007a. The Expressiveness of Traditional Slovenian Military Songs. In: The Regiment Is on the March. From the Archives of the Institute of Ethnomusicology. Ljubljana: ZRC SAZU, pp. 3-43.

Klobčar, Marija 2007b. Fear and Courage in Traditional Slovene Military Songs. Slovene Studies Journal, Vol. 29, No. 1-2, pp. 35-55. http://dx.doi.org/10.7152/ ssj.v29i1.14031.

Kozorog, Miha 2002. Glasba-prostor-identiteta: primeri iz Tolmina po letu 1945. [MusicSpace-Identity: Cases from Tolmin After 1945.] Bachelor's thesis. University of Ljubljana.

Kozorog, Miha 2010. "Pa Tminu se patiepaje": življenjski svet lokalne skupnosti mladih v uglasbenih besedilih. Prvi del: uglaševanje. [“The Ramble around Tolmin”: The Life-World of a Local Youth Community Reflected in Lyrics. Part One: Tuning.] Glasnik SED, Vol. 50, No. 3-4, pp. 33-41.

Kozorog, Miha 2011. "Pa Tminu se patiepaje": življenjski svet lokalne skupnosti mladih v uglasbenih besedilih. Drugi del: ustvarjanje lokalnosti. [“The Ramble around Tolmin": The Life-World of a Local Youth Community Reflected in Lyrics. Part Two: The Creation of Locality.] Glasnik SED, Vol. 51, No. 1-2, pp. 10-16. Available at https://issuu.com/glasnik_sed/docs/glasnik_sed_-_junij_2011/90, last accessed on 24 July 2018. 
Leydi, Roberto 1963. Il povero soldato 2. Serie "Canti politici e sociali." DS 13. Milan: I dischi del sole. Vinyl (7”, EP).

Muršič, Rajko 2000. Trate vaše in naše mladosti: zgodba o mladinskem in rock klubu. [The Lawns of Your and Our Youth: A Tale about Youth and Rock Club.] Ceršak: Subkulturni azil.

Navaro-Yashin, Yael 2012. The Make-Believe Space: Affective Geography in a Postwar Polity. Durham \& London: Duke University Press.

Pivato, Stefano 2007. Bella ciao: Canto e politica nella storia d'Italia. Bari: Editori Laterza.

Saunders, Nicholas J. 2001. Matter and Memory in the Landscapes of Conflict: The Western Front 1914-1999. In: Barbara Bender \& Margot Winer (eds.) Contested Landscapes: Movement, Exile and Place. Oxford: Berg, pp. 37-53.

Tul, Vlasta 2002. “Na Mostu se vse zve, če ne prej pa...”: Komentirana objava zapisnika seje krajevne organizacije Socialistične zveze delovnega ljudstva Most na Soči z dne 15. julija 1953. ["In Most na Soči Everything Gets Out, If Not Before Then...": A Commented Publication of Notes from the Meeting of Local Organization of Socialist Alliance of Working People of Most na Soči from July 15, 1953.] Zbornik Pokrajinskega arhiva v Novi Gorici. Nova Gorica: Pokrajinski arhiv, pp. 132-159. 


\title{
LEARNING BY COLLECTING: AMATEUR COLLECTORS AND THEIR SHIFTING POSITIONS IN THE ISONZO FRONT HERITAGIZATION AND TOURISM ADAPTATION
}

\author{
Boštjan Kravanja \\ Department of Ethnology and Cultural Anthropology \\ Faculty of Arts \\ University of Ljubljana, Slovenia \\ e-mail: bostjan.kravanja@ff.uni-lj.si
}

\begin{abstract}
Modern collection of war-related artifacts and military objects in the Upper Soča Valley started in the 1980s and increased after Slovenia gained independence in 1991. Today, eighteen private collections are open to the public in the Gorizia region (Koren 2015: 205), but it is estimated that there are fifty to one hundred more (Kofol 2015: 276) that have not been inventoried by any publicly funded institutions. This article ${ }^{1}$ evaluates the phenomenon and growth of collecting artifacts from the Isonzo Front. The heritagization of the front's material culture and its adaption to tourism started in 1990, but it greatly developed in the following decades. The global marking of the First World War centenary (2014-2018) gave this development further impetus. Within these processes, amateur collectors are increasingly perceived with ambiguity. On the one hand, "good" collectors are presented in the front's heritage landscape as its founding fathers, but on the other "bad" collectors are presented as problematic in relation to the region's archaeological heritage.
\end{abstract}

Keywords: heritage management, heterotopias, Isonzo Front, private collections, tourism development

The Isonzo Front was part of the six-hundred-kilometer front between Italy and the Austro-Hungarian Empire. It was ninety kilometers long and it stretched along the Soča River between the Julian Alps and the Adriatic coast. The front was formed on May 23rd, 1915, when Italy declared war against Austro-Hungary, and lasted until November 9th, 1917, when the Italian army was defeated by Austro-Hungarian and German forces near the town of Kobarid (Italian: Caporetto; Koren 2015: 17-19). The front claimed the lives of about five hundred 
thousand soldiers of various nationalities, which were brought to the front from different parts of the Austro-Hungarian Empire and Italy. Moreover, the front deeply affected the civilian population because many residents of nearby towns and villages were evacuated to various parts of the Austro-Hungarian Empire and Italy (Sedmak 1997: 91-92).

The Isonzo Front profoundly changed the landscape of the Soča Valley. This change has been inscribed into the Soča Valley similar to a palimpsest of various layers of "conflict landscapes" throughout the twentieth century (see Saunders et al. 2013). A complex system of fortifications, trenches, shelters, caverns, and barracks was connected to the hinterland by military roads and the railway. The hinterland consisted of numerous depots, waterworks, cableways, hospitals, cemeteries, brothels, and workshops, and they strongly cut into the life of the civilian population. At least in Kobarid, most of this supply infrastructure was located in towns and villages (see Sedmak 1997).

Although much more could be said about life before, during, and after the First World War (see Svoljšak 1993, 2017) and about particular battles on the Isonzo Front (see Cimprič 2017; Koren 2015; Kuhar 2017; Močnik 2017), this article rethinks how the front's legacies have been treated, changed, reorganized, and presented in the last three decades, after the initial opening of the Kobarid Museum of the First World War in 1990. In particular, I am interested in private collections and their changing position when the institutional landscape of front-related organizations, associations, and stakeholders has developed into a vast network, which, despite its general inclusiveness and dialogic orientation in producing meanings, is establishing specific conceptual and cultural orders (Meijer-van Mensch 2017: 25).

In relation to objects and things, these orders create a gap that can be described with Foucauldian heterotopia, a concept that "reflects on how potentially regulative these collective modes and practices are" (ibid.). A potential unwanted result of this heterotopic gap between physical places and their social construction is the consolidation of heritage institutions in "unified space", which can create a "homogeneous "monster" (ibid.) that suppresses the subjectivity, creativity, passion, inspiration, and enthusiasm of amateur collectors instead of being inspired by them (Meijer-van Mensch 2017: 26-27).

Given that adaption to tourism is another powerful stream of development in the Upper Soča Valley, which goes in at least two directions - one toward heritagization of the Isonzo Front remains in situ, and the other toward creating hospitality (infra)structures - amateur collectors have found themselves in an inevitable process of "soft" integration of their hobby into this increasingly complex landscape. They have been given credit by publicly funded museums, such as the Tolmin Museum and the Nova Gorica Museum, to open their collec- 
tions to the public. They are also presented under the aegis of the Walk of Peace in the Soča Region Foundation, a complementary institution to the Kobarid Museum, which was established in 2000. Their knowledge about the front and local cultural history has been recognized as useful, enriching, and important for the overall character of the valley. However, this type of knowledge is also seen as an inferior addition to "real knowledge" because it focuses on the battlefields, military history, and technologies of war.

What I show here is that the knowledge from amateur collectors' study of wartime artifacts is what tourism development of the Soča Valley needs just as much as it needs a sensitive, humanized, and antiwar narration of the Isonzo Front. Tourism cannot survive without at least some spectacular content that surprises, animates, and engages visitors and guests. As Scheller and Urry (2004: 6) state, "places [to play] are not fixed or given, but are themselves 'in play' in relationship to multiple mobilities". Tourism constantly needs new, exciting places, which are "always 'around the corner' surfacing out of the swirl of economic, social and cultural processes" (ibid.). The private collections with their often special and eccentric owners are an example of such places in play. Furthermore, collectors' way of learning about the front has importantly shaped (and still shapes) local endeavors for the front's heritagization and its interpretation.

\section{INSTITUTIONALIZATION OF ISONZO FRONT HERITAGE}

The marking and commemoration of the First World War centenary (2014-2018) was organized globally through hundreds of events, projects, resources, and news items. In the context of these activities, ever new approaches, meanings, and presentations of the First World War have been prepared for future generations. The First World War became a prominent subject for military, cultural, and art historians, museum and heritage professionals, political scientists, and anthropologists (see, e.g., Hudales \& Roženbergar 2017; Jezernik \& Fikfak 2018). The war's multifaceted and many-layered legacy, assessed and organized through these new endeavors, is becoming increasingly complex. An important orientation of these new thoughtful public representations of the First World War is a sensitive and contextual approach toward different people that suffered because of it, rather than solely a reconstruction of the war's battles and offensives (see also Gorgus 2017; Kregar 2017; Svoljšak 1993, 2017). ${ }^{2}$

In addition, the First World War's cultural significance is emphasized among archaeologists (Košir 2014; Matás \& Roberts \& Telfer 2014; Saunders 2004, 2010). Their new perspectives are based especially on a shift from older bat- 
tlefield archaeology to a wider, more socially oriented vision that is enriched with anthropological theory and conflict archaeology (Saunders 2010; Saunders et al. 2013). Among relevant issues for this new archaeological orientation, (trans)nationalization of the First World War heritage and its commercialization for tourism purposes is highlighted as well as private collections of war artifacts and "a vigorous international trade in such items" (Saunders 2010: 27). Regarding this trade, Saunders (2010: 29-30) wrote:

... objects can be dug up by archaeologists or by looters, and can travel by a variety of different routes to a private collection, a museum, or an internet auction site. If enough interesting items are recovered from the ground they can become the centerpiece of a new museum exhibition that in turn becomes a "must-see" stop on a battlefield tour, and at which, on occasion, other battlefield souvenirs (real and fake) are sold. In this way it can be seen how war artefacts can become caught in a spider's web of war history, war heritage and tourism, and are further entangled with issues about their authenticity and the ethics of collecting and exhibiting them.

This "spider's web" in which war artifacts are set in heterotopias that emerge between ideologies and collections on the one hand and in "constant circulation" (Saunders et al. 2013: 47) on the other is even more complex, especially if one considers the endeavors in creating humanized and democratized perspective on the First World War, which has gone along with such treatment of history since the 1970s (Gorgus 2017: 138). Thousands of artifacts without reference to their owners are useless for such a democratic interpretation of history, which wants untold stories to be told, unheard voices to be heard, meaningful artifacts with stories to be contributed, and reflections and feelings of the visitors and the local population to be shared (see Gorgus 2017: 144).

The Kobarid Museum was also conceived in this vein. It was established by a group of local enthusiasts in 1990. With the help of curators from the Nova Gorica Museum, they approached the First World War with an antiwar message, and primarily highlighted the tragedy of ordinary men and their personal stories. This aspect strongly prevailed over the military operations, battles, and warfare, even if the cover story of the Kobarid Museum is the Twelfth Offensive of the Isonzo Front, the "Breakthrough at Caporetto", or the "Miracle of Caporetto" (Walk of Peace 2017). ${ }^{3}$ The exhibitions that the Kobarid Museum hosted after its initial success ${ }^{4}$ were conceived as a cycle in which all of the nations involved in the Battle of Caporetto had an opportunity to present themselves. With these exhibitions, the museum obtained additional documentation about the Isonzo Front from archives and war museums in Vienna and Budapest. In the context of this, the former director of the Kobarid Museum, Jože Šerbec, said in November 2011: 
We are not a museum of artifacts. We are predominantly a museum of stories, documents, photographs, and cartography... we are not talking about artifacts, but about a fund. Because a grenade, if it is Hungarian, it does not mean anything, and also if it is German or Italian. You have way too much iron in private collections, or, let's say, in the state museums. On both this or that side.

Although this distance from amateur collectors is still present at the Kobarid Museum, the Walk of Peace, a sister institution of the Kobarid Museum, which was established in 2000, recognized the collectors as independent presenters of history and war, and it represents them in its brochures, guides, and main exhibition hall (Fig. 1).

The aim of the Walk of Peace was to add to the Kobarid Museum's achievements in terms of acquiring deeper knowledge about the Isonzo Front, presenting it in a more scholarly way, creating, managing, and promoting its battlefields in situ, and coordinating many front-related activities that started to mushroom locally and nationally after the Kobarid Museum's success. This time the pacifist message was put at the forefront of the Isonzo Front presentation and was institutionalized in the name of this new organization and with its logo. It is notable that the soft image of a dove almost diametrically opposes the dramatic image of the breakthrough, which is symbolized in the Kobarid Museum's logo (Fig. 2 \& 3).

Figure 1. Private collections are represented in the main exhibition hall of the Walk of Peace. Photograph by the author 2017.

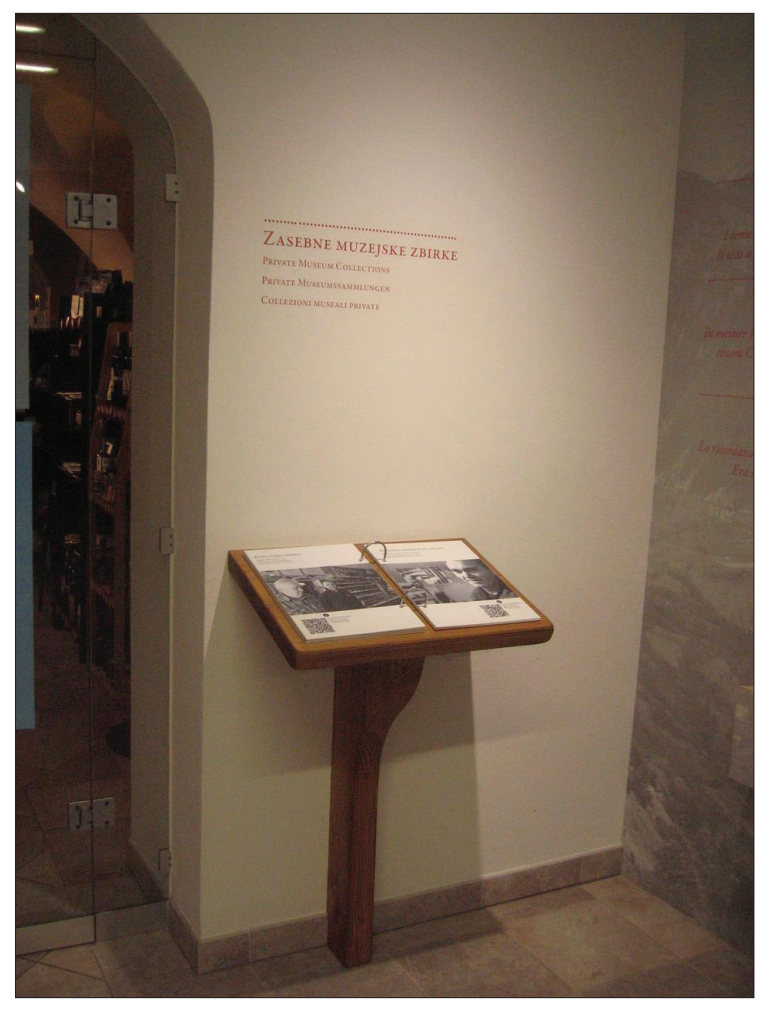





Figure 2 \& 3. Two styles of narratives about the Isonzo Front as seen in the logos of the Kobarid Museum (left) and the Walk of Peace (right).

In the next decade, the Walk of Peace made an enormous effort in preparing the landscape for cultural tourism. Battlefields were presented in a scholarly manner, trenches were cleaned, equipped, and preserved, and outdoor museums were established on the frontlines and connected with a thematic trail from the Alps to the Adriatic (see Koren 2015). Specialized tourist guides were educated and trained for the area, a new documentation-information center was established, thematic exhibitions, conferences, and other First World War-related events were held, and, last but not least, EU funds were obtained through various cooperation and cross-border programs and projects. All of these activities and many more also attracted various heritage specialists, museum curators, professional historians, and other social scientists and scholars in the humanities. In two decades or so, the front was given a scholarly touch, promoted, adapted for tourism, and made ready for the global commemoration of the First World War centenary (2014-2018; Fig. 4).

With the centenary of the First World War, the organizations related to the Isonzo Front are crucially set within a European conceptual and cultural order, which in relation to the landscapes of the Soča Valley creates regulative heterotopias (Meijer-van Mensch 2017: 25) and extends into many aspects of the local population's lives. The physical landscape is interpreted with a "unified space" (ibid.), a network of institutions, programs, associations, and official 

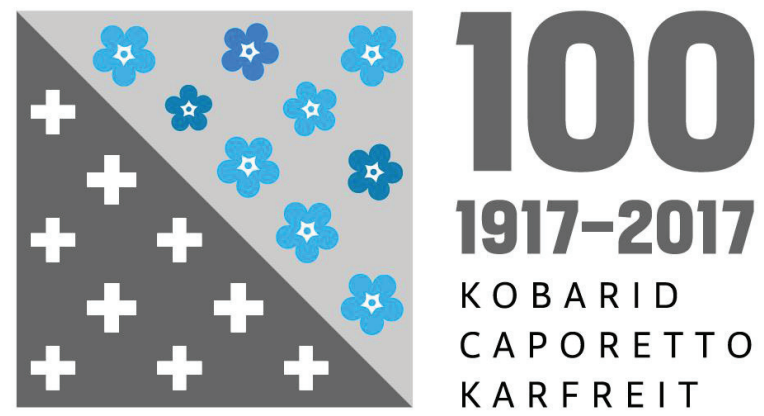

Figure 4. The Walk of Peace logo for marking the First World War centenary.

bodies, which does not directly suppress the creativity, passion, and subjective initiatives, but selects and tolerates them. As long as the new ideas and initiatives fit into the general ideological order of commemoration of the First World War and sustainable tourism development, they can fruitfully enrich the equipped, clean, and sanitized caverns, trenches, and fortifications or - for better or worse - add new ones. This order is therefore not stifling and dominating in the Adornian sense of "cultural industries". It instead promotes inclusiveness, which is epitomized in the softer concept of "creative industries".

The full package of the Isonzo Front heritage includes all sorts of representations and dimensions of the front, which seek to fulfill the needs of other segments of visitors to the Soča Valley as well as the needs of the local population. In tourism, the heterotopias of the First World War interpretation and sensemaking are flexible and not only allow, but encourage and promote cultural activities, events, and involvement of as many initiatives as possible, which add to the basic mission of commemorating the dead soldiers, highlighting the madness of war, and pointing to the suffering that wars bring to life in general.

With this firmly established framework and deep symbolic message that, again, was cultivated from the very beginnings of the front's heritagization, the curse of labeling the commemorative landscapes of war as a field for "dark tourism" or "thanatourism" (see Baldwin \& Sharpley 2009; Seaton 2009) was successfully avoided. Various other stakeholders could enter the field and engage in serious tourism business, which has brought to the surface the more trivial and spectacular content of the front's landscape, so that even the Kobarid Museum and the Walk of Peace could not resist contributing their share. 


\section{METHODOLOGY}

The information for this article is derived from a series of short ethnographic field studies, which were carried out within a program at the University of Ljubljana's Department of Ethnology and Cultural Anthropology. Kobarid and the Upper Soča Valley were already selected for research tutorials between 2011 and 2013, when tourism was at the forefront of the research (see Kravanja 2014: 94-97). Between 2015 and 2017, the ethnographic field tutorial was organized as shown in Table 1.

\begin{tabular}{|c|c|c|c|}
\hline Field & Dates & $\begin{array}{l}\text { Students, } \\
\text { number, } \\
\text { course }\end{array}$ & Subjects \\
\hline $\begin{array}{l}\text { Bovec and surrounding } \\
\text { villages }\end{array}$ & $\begin{array}{l}\text { Nov. } \\
20-22, \\
2015\end{array}$ & $\begin{array}{l}\text { First year, } \\
11, \\
\text { Anthro- } \\
\text { pology of } \\
\text { Tourism }\end{array}$ & $\begin{array}{l}\text { Inter-institutional space } \\
\text { of tourism; tourism } \\
\text { landscapes; participation } \\
\text { and ownership of the local } \\
\text { population }\end{array}$ \\
\hline $\begin{array}{l}\text { Kobarid and } \\
\text { surrounding villages; } \\
\text { Outdoor museums in } \\
\text { the mountains; } \\
\text { Private collections in } \\
\text { the region; } \\
\text { Monte San Michele, } \\
\text { Italy; } \\
\text { Memorial on Cerje Hill } \\
\text { (see endnote 2) }\end{array}$ & $\begin{array}{l}\text { Nov. } \\
17-20 \\
2016\end{array}$ & $\begin{array}{l}\text { Second } \\
\text { year, 11, } \\
\text { Anthro- } \\
\text { pology of } \\
\text { Space and } \\
\text { Place }\end{array}$ & $\begin{array}{l}\text { Historically thematized } \\
\text { landscapes; social } \\
\text { circumstances and actors; } \\
\text { the First World War } \\
\text { landscape; memory and } \\
\text { heritage; borders and } \\
\text { borderlands; tourism; } \\
\text { space and place }\end{array}$ \\
\hline $\begin{array}{l}\text { Kobarid and } \\
\text { surrounding villages; } \\
\text { Outdoor museums in } \\
\text { the mountains; } \\
\text { Tolmin and its } \\
\text { institutions; } \\
\text { Most na Soči; } \\
\text { Private collections in } \\
\text { the region; } \\
\text { Sveta Gora above Nova } \\
\text { Gorica; } \\
\text { Memorial on Cerje Hill } \\
\text { (see endnote 2) }\end{array}$ & $\begin{array}{l}\text { Nov. } \\
23-26, \\
2017\end{array}$ & $\begin{array}{l}\text { Second } \\
\text { year, 18, } \\
\text { Anthro- } \\
\text { pology of } \\
\text { Space and } \\
\text { Place }\end{array}$ & $\begin{array}{l}\text { Landscapes of the First } \\
\text { World War in Slavia } \\
\text { Friulana; associations } \\
\text { thematizing the First World } \\
\text { War; landscape through } \\
\text { the eyes of collectors; } \\
\text { reenactments of war in situ; } \\
\text { monuments and memorial } \\
\text { trails; cemeteries and } \\
\text { ossuaries; the First World } \\
\text { War and nature; thematic } \\
\text { hiking trails and their } \\
\text { future; landscapes of } \\
\text { the First World War in } \\
\text { protected natural areas }\end{array}$ \\
\hline Total & 11 days & 40 students & 19 subjects \\
\hline
\end{tabular}

Table 1. Fieldwork research tutorials 2015-2017. 
I prepared the fieldwork tutorial in Bovec (2015) myself, but organized the subsequent fieldwork (in 2016 and 2017) together with a colleague, Miha Kozorog. Because both of us were born in the Upper Soča Valley, we already knew most people working in the field, and together we prepared the logistics for the fieldwork. We conceived the research framework, conducted preparatory seminars (reading literature, discussions, and profiling themes and departure points with the students), directed the fieldwork (meetings with publicly funded institutions, guided field excursions to outdoor museums, providing contacts with relevant interlocutors, and conducting focus groups in the evenings), and assessed the student results (presentations of field materials, and evaluating the quality of the field materials and written essays). The collected field materials (interviews, transcriptions, photographs, and field notes) were delivered to the documentation center at the Department of Ethnology and Cultural Anthropology under the title "Landscapes of the First World War in the Soča Valley".

For this article, the materials derive from my field visits to amateur collectors and their private collections, which I made together with students (see Fig. 5).

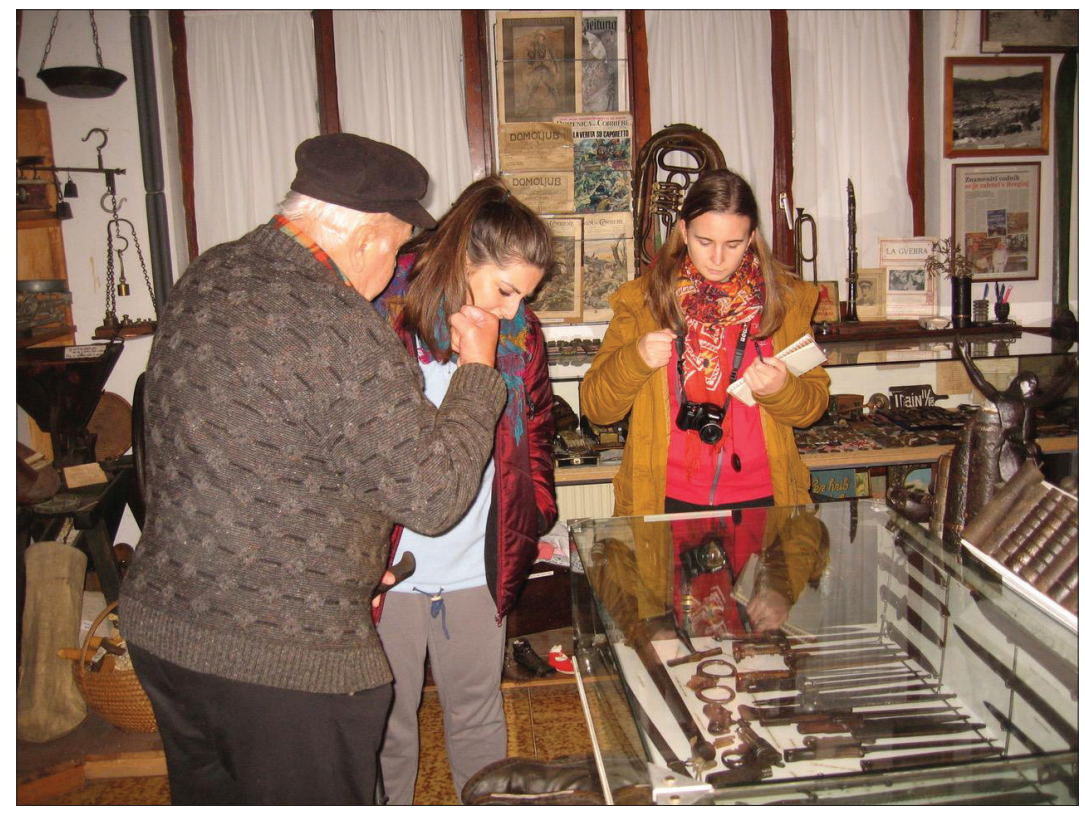

Figure 5. Students conducting ethnographic fieldwork with Zdravko Mazora, Sr., in his private collection in the village of Breginj. Photograph by the author 2017. 
Because Kobarid is my hometown, I have been observing its tourism and heritage development since the mid-1990s, during my student years, when I was also involved in revitalizing remote areas and villages on the Italian border. Within those projects, I already recorded private and publicly funded collections in the area and interacted with most of the local people involved in culture, museum curators, and development managers. Before the current project on the heritage of the First World War (see Acknowledgements), I was also involved in the national research project on Triglav National Park (2011-2014; see Bajuk Senčar 2013; Fikfak \& Bajuk Senčar 2015; Hudales 2015; Kozorog \& Poljak Istenič 2013), which gave me a good basis for further research on the heritage of the Isonzo Front (see Kravanja 2014). For all of these reasons, this article is written in an interpretive style that, on the one hand, covers the last three decades and, on the other, deals with "reading" the recent developments concerning the position of amateur collectors and their collections in the context of the front's heritage and the institutional tourism landscape.

\section{AMATEUR COLLECTORS OF ARTIFACTS FROM THE ISONZO FRONT}

The first accumulation of material from the Isonzo Front started in the aftermath of the First World War. Refugees from the front began returning to their ruined homes in the 1920s and started to clear the battlefields and remove wartime debris from the vicinity of their homes. Raw materials, especially iron, were either sold to wholesalers or recycled; many items such as tinplate, metal roofs, (barbed) wire, wooden posts, helmets, shoes, clothes, pipes, canteens, and anything of any value were reused for various private purposes in households. Entire families could live by selling iron. In the town of Kobarid, one of these recyclers was a former Italian soldier from the Isonzo Front, Gobo Santo. He made a living for himself and his family by accumulating debris from the war. Ivo Krajnik, one of the first collectors in the region, dedicated his collection of approximately 3,500 items to him (Fig. 6).

Regardless of this initial clearing of the battlefields, much material - in fact, tons of iron - have remained not only beneath the ground, but on the surface of the Soča Valley and its surrounding mountains and plains until the present day. Especially materials made of iron and tinplate (and such were the majority of strictly military items) remained in fairly good condition over the decades, when the first collectors found them and started to create museums and collections with them. 


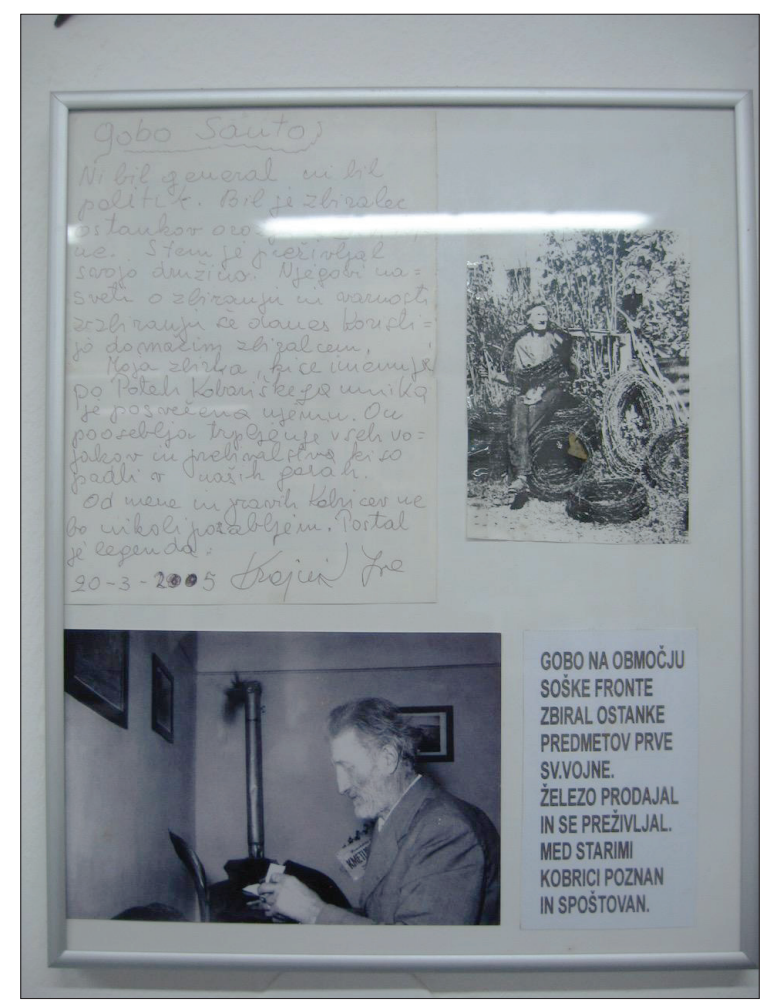

Figure 6. A dedication to a forerunner of the collectors of the Isonzo Front materials, an Italian soldier Gobo Santo. The museum collection The Paths of Retreat at Kobarid 1917 in Kobarid. Photograph by the author 2017.

\section{THE EARLY COLLECTORS AND THEIR METHODS}

The early collectors were primarily interested in local history. The content of their collections was far from being only weapons and military equipment. They intentionally searched for anything old that remained from the past generations. Important triggers for collecting were also the earthquakes (in 1976 and 1998), when various items from damaged and demolished houses were taken to the homes of these early collectors. The locals got used to these strange men, and themselves started to bring them various things, from rags and bones to things that they were attached to and could not throw away for sentimental reasons. The nature of the early collectors' work was therefore highly interactive. They were always considered somewhat odd figures because through their hobby they stood out in the community more than others. 
The private collections started being seriously inventoried by the Tolmin Museum in the mid-2000s (Kofol 2015: 276). The creation of inventories led to consultation between museum curators and collectors because each side had specific knowledge that the other lacked. The Tolmin Museum, for example, held a cycle of lectures specifically for collectors, where restoration specialists presented various procedures for maintaining and restoring various materials (ibid.). Today, artifacts from private collections are occasionally incorporated into the museum's public exhibits.

However, the number of amateur collectors that are ready to open their collections to the public is decreasing. If an amateur collector wishes to do so, his collection has to be inventoried. Each artifact must have a document and a copy of the record must be stored at the Tolmin Museum. On the one hand, such artifacts are under supervision and cannot be sold, exchanged, or given away. On the other hand, the inventoried private collections together form a powerful heterotopic tool for communicating various ideas and messages to the public (see, e.g., Poljak Istenič 2015; Dapit \& Ivančič Kutin \& Ledinek Lozej 2015). However, the collectors cannot participate in constructing these messages because the basic register they work with is different. They maintain the artifacts and organize them into the order of a collection, whereas the conceptual and social orders that create heterotopic relations between things and their interpretation are another matter. In relation to a publicly funded museum, the amateur collectors can turn into some sort of depot maintenance workers or repairmen, whereas their collections, once they are inventoried, become some sort of manageable multi-sited common depot.

In the framework of tourism development in the Soča Valley, I already noted that the private collections started to be promoted within the Walk of Peace exhibition hall as an additional or optional attraction for visitors interested in the front. In this framework, the private collections are added to the Isonzo Front heritage landscape of outdoor museums, trails, interactive maps, information flows, exhibitions, and more. This conceptual and social order of tourism is slightly different from that of museums because it brings the collectors onto an (often international) stage as spokespersons and proponents of the material authenticity of the war. Their role within this framework is to heterotopically complement the master story with brutal "hard evidence" of the weapons and to highlight the technological side of the First World War warfare. In this way, the central Isonzo Front heritage institutions can distance themselves from the vulgar brutality of war and cultivate the interpretation of war in accordance with the major standards of European commemoration because the collectors bear the task of satisfying leisure tourists' quest for more exciting and spectacular stimulus instead of them. 


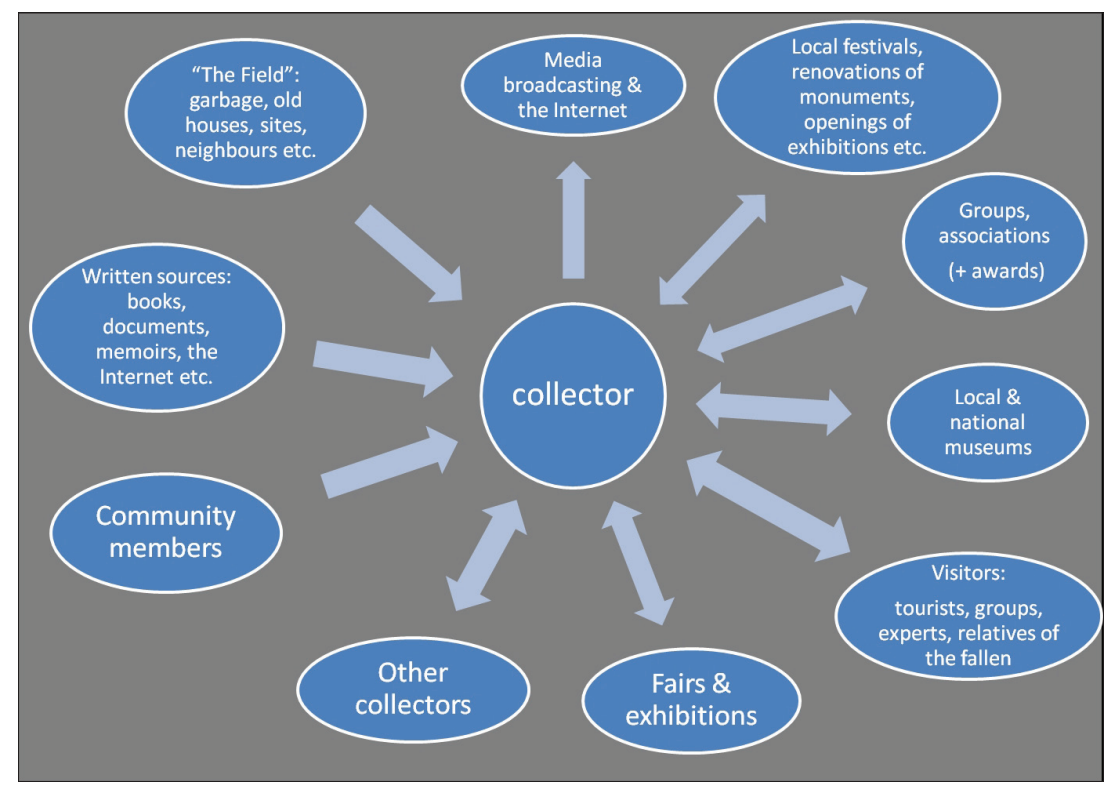

Figure 7. Channels and fields of interaction through which the collectors acquire artifacts, communicate information and knowledge about them, and engage with others in maintaining their collections.

However, apart from including amateur collectors in these unifying heritage and tourism frameworks, and giving them particular roles within them, the collectors themselves are in constant interaction with the local surroundings. They have therefore built their own additional networks and channels, through which they communicate with their items and with the knowledge that they acquire from them (Fig. 7).

\section{THE INTRODUCTION OF MILITARY OBJECTS AND METAL DETECTORS INTO THE COLLECTORS’ WORLD}

Military items that remained on remote battlefields, either from the Isonzo Front or from the Second World War, gradually became more interesting to some of these early amateur collectors in the 1980s. The time was also ripe because of the relaxed control of the authorities in communist Yugoslavia (see Kaučič 2017). These items were cleaned, repaired, arranged, stored, selected, and gradually incorporated among other artifacts in the collections. 




Figure 8. The late Ivo Krajnik, Sr. (left) and his friend inspecting grenades collected in the field. The museum collection The Paths of Retreat at Kobarid 1917 in Kobarid. Photograph by the author 2017.

For many, the military items soon became a particularly interesting sort of artifact. Their nature was different and they were primarily attractive because of their technological features. Being "anonymous", they were similar to "anonymous" fallen soldiers, yet to be identified. However, their detached objectivity and their difficulty in both ethical and technological terms was what initially attracted their collectors. On the surface, the actual use of these objects had to be imagined and the context of this imagination was the technological evolution of weapons and military equipment. In contact with these objects, including with their enormous quantity, advancing technological development was obvious and pointed to the early exponential growth of industrial production.

However, among the early amateur collectors, a shift toward imagining the life of the common soldier soon occurred because they already had experience with other artifacts that they had most often acquired in a package with a story. The sections of military artifacts, which were usually arranged according to the national armies that fought on the Isonzo Front (Fig. 9), of course remained there and were further complemented either with the help of fellow collectors or through the rapidly growing First World War antiquities market. In line 


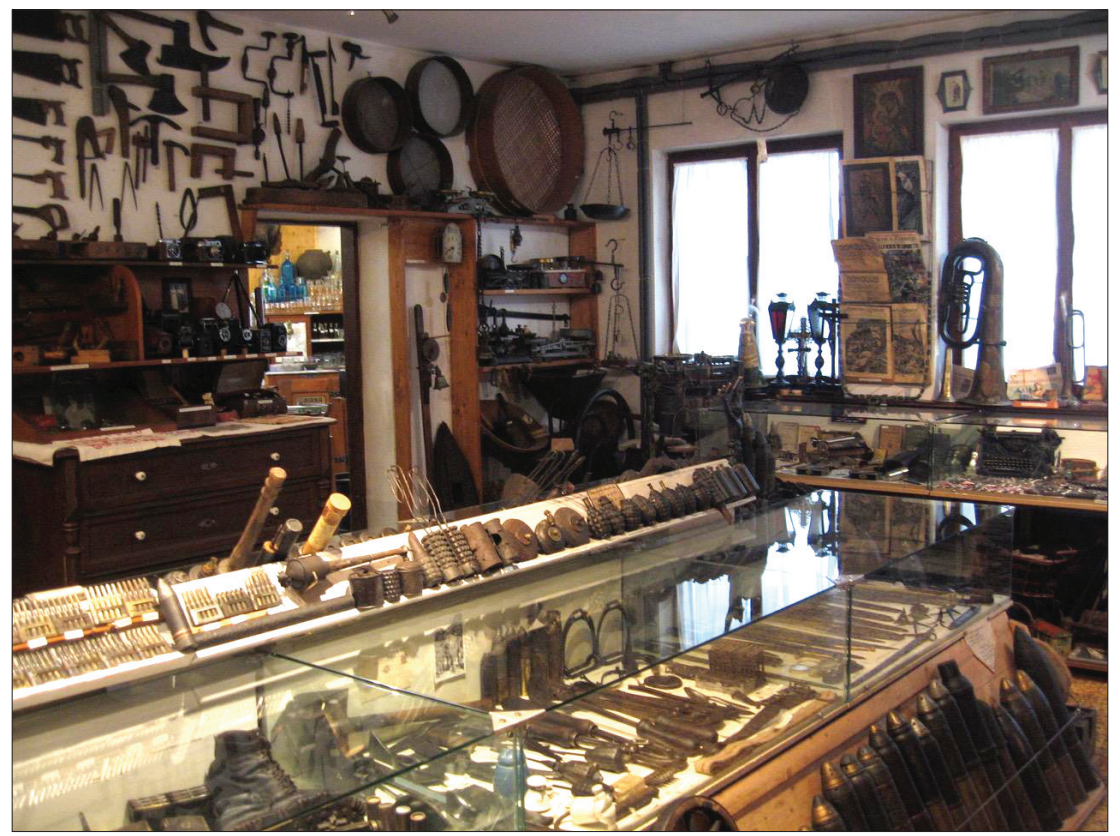

Figure 9. A military artifact section against an old agriculture-related section in a private collection. Ethno-war collection in Breginj. Photograph by the author 2017.

with this flow, the early collectors started using metal detectors as soon as they became available, but many of them also turned their interest away from weapons to small personal items of soldiers, which bore more potential for imagining the experience of war. Last but not least, some also turned away from the war altogether and found more excitement in older, even prehistoric items that, in the best possible scenario, led them to consult with an archaeologist (Fig. 10).

In comparison to this older generation of collectors and their children (and now even grandchildren), the newcomers were not capable of such shifts. The context for the new metal detector users was different because the communication channels had changed and the availability of information was much greater, and was also of a different nature. The established collectors often claimed that the old material culture in itself is not interesting to the new generations. However, they did not see that the military objects better fit contemporary quantity-oriented values, where the completeness of a specialized collection of a certain group of objects is perhaps more important than the individuality and extraordinariness of major pieces. 


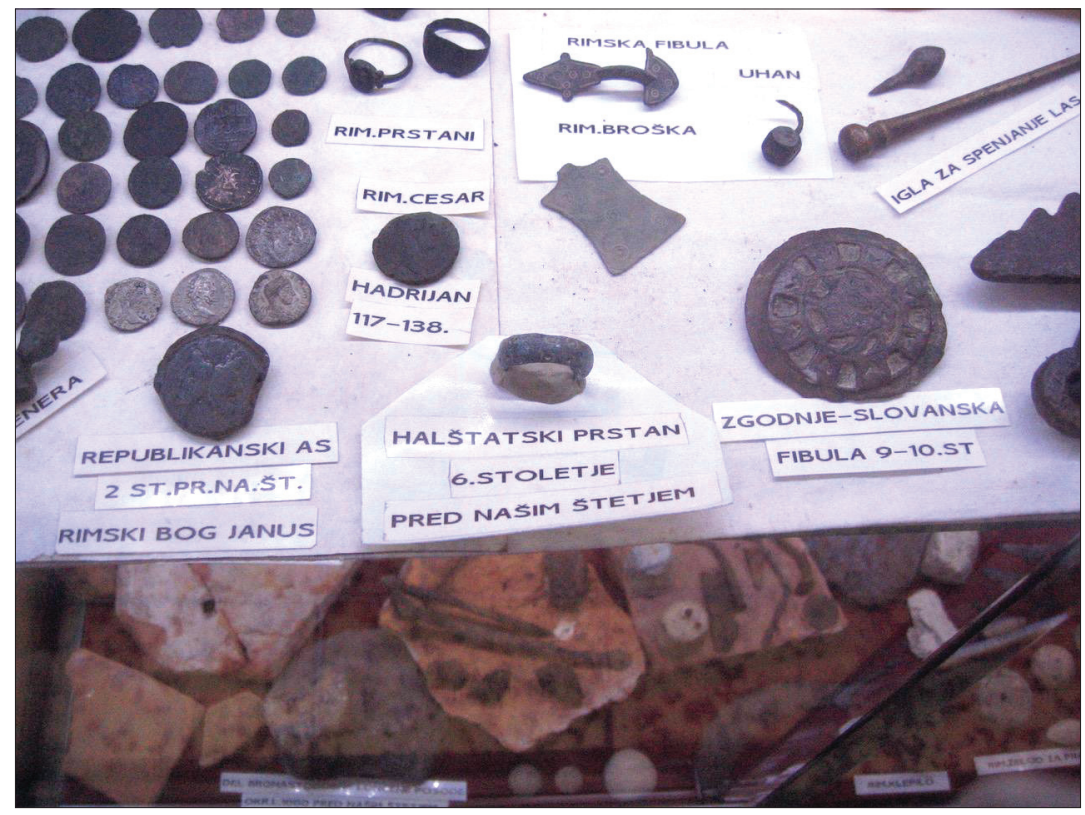

Figure 10. A 'big find': a Hallstatt ring from the 6th century BC confirmed by archaeological analysis as an important find of the local area. The ethnowar collection in Breginj. Photograph by the author 2017.

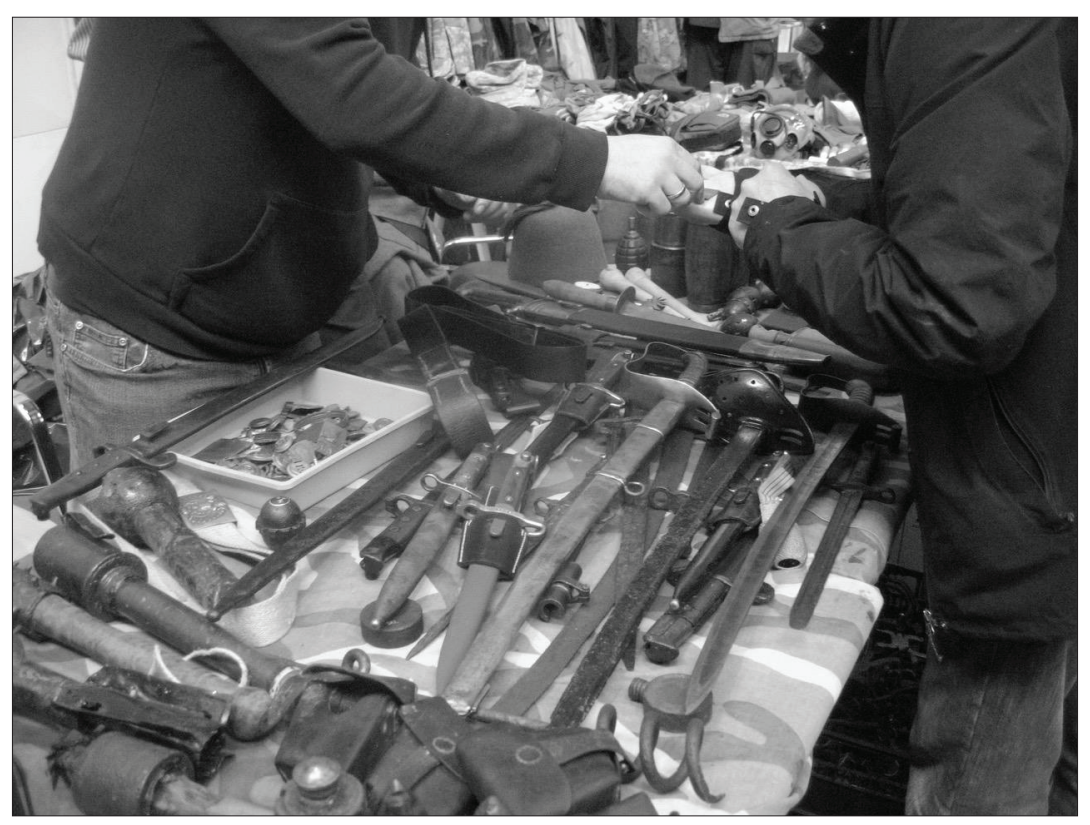

Figure 11. The First Word War antiquities market in Šempeter pri Gorici, organized by the Isonzo Front association. Photograph by the author 2016. 
Concerning the First World War materials on the Isonzo Front battlefields, there soon appeared a feeling that items are vanishing due to the antiquities market. "A lot was sold, but a lot is still lying there," is a common claim of the early collectors. However, they have also claimed that nowadays it is difficult to find very typical artifacts in the Soča Valley. The material value of the artifacts on the market varies in any case because it has to be regarded in the context of the collection where the item is about to be placed. At any rate, the memorial value for newcomers, in contrast to early collectors, is less important than the material value. Similar to the early collectors, detached objectivity and technological focus are at the forefront in the market. Among younger amateur collectors, who combine their hobby with recreation and hiking, even the simple rush of adrenaline that accompanies the signal of the metal detector is enough to continue their activities.

\section{IN CONCLUSION}

This article showed how the conceptual and cultural order of presenting the Isonzo Front heritage has gradually tightened up Isonzo Front-related landscapes through the work of the Kobarid Museum and the Walk of Peace. Because an important feature of contemporary museums is the dialogical nature of their activities, the status of their collections has changed (see Hudales \& Roženbergar 2017). More than museums of artifacts, these institutions are increasingly becoming documentation and communication centers. In the light of this, it is noteworthy how visionary the founders of the Kobarid Museum already were in the 1990 s.

However, along with this, a heterotopic gap opened between interpretation of the battles of the Isonzo Front and its material remains, which were gathered among the population of the Soča Valley, most notably in private collections. The collectors were integrated into these increasingly complex orders and have gradually opened their private collections to the public. On the one hand, their relations with museum curators were mutually beneficial because they obtained much-needed access to professional knowledge; at least some of them have made good use of this and continue to cooperate with the curators. On the other hand, the museum curators and heritage specialists are representatives of publicly funded institutions that are in charge of maintaining order, making possible supervision over the private collections. Regarding this point, the relations between them are normally tenser because the collectors must subordinate their activity to experts and the dominant orders that they represent. 
This tension further intensified when the new Heritage Protection Act changed the rules of the game in 2008. Article 3 of this act newly defined archaeological heritage. Arms, ammunition and other military materials, vehicles, and vessels or their parts that had been under the ground or water at least fifty years were included. With this act, the collection of war-related materials became strictly forbidden, and the act also interferes with the existing private collections. In practice, it did not achieve its desired goals because violations are impossible to track down in the field.

The second stream of thought in this article concerned tourism development in relation to the global commemoration of the First World War centenary (20142018). Because the need to present detailed military knowledge about Isonzo Front battles, tactics, and the like could not be pushed to the side this time, even the Walk of Peace and the Kobarid Museum decided to cross the subtle line between participatory strategies and dialogic approaches to history on the one hand and detached objectivity emphasizing the destructive side of warfare on the other. The Battle of Caporetto (see endnote 3) was reenacted at Mount Kolovrat on September 17, 2017, with 150 actors on both sides, pyrotechnic effects, and simulations of explosions.

The pressing factor for supporting these kinds of representations that seem at odds with scholarly and democratized narratives of historians, professional museum curators (see endnote 2), and national institutions was - apart from the hectic pace of organizing the First World War centenary events - (sustainable) tourism development and hospitality practices. Publicly funded institutions did not want to openly display the weapons, military equipment, and technological evolution that so importantly marked the beginning of twentieth-century industrialized warfare (Saunders 2004: 5). This was left to the amateur collectors, and for this task they had space as well as support from and proper representation by the decision-makers of the Isonzo Front heritage institutional environment. Now it seems that also these roles, or at least the division of work, is changing or perhaps even turning upside down.

This article showed how the early collectors gained the reputation of deserving members of their communities, whereas the reputation of contemporary newcomers on the collecting scene is diametrically opposed: they are treated as metal detector users, looters of the valuable archaeological heritage of the Isonzo Front, who dig for war-related artifacts and other metal items to sell on the antiquities market. It seems that the times of traditional collectors are over, and the question of how to integrate the "bad" collectors into the heritage networks instead of chasing them away, with all of the pitfalls that this might bring to the Upper Soča Valley's heritage, remains open for further examination. 


\section{ACKNOWLEDGEMENTS}

I am grateful to the Kobarid institutions for presentations of their work and their availability to the students from the Department of Ethnology and Cultural Anthropology of the University of Ljubljana. The amateur collectors of the Soča Valley did a great job curating through collections and being available for detailed interviews. I am grateful to the Student Organization and the Student Board of the Faculty of Arts in Ljubljana, which funded part of the student costs for the project Landscapes of the First World War (2016 and 2017). Thanks to Miha Kozorog for cooperation in directing the fieldwork research tutorials. I also benefited tremendously from the numerous discussions with the students in the courses Anthropology of Tourism and Anthropology of Space and Place, and in the fieldwork in Kobarid (2015-2017), as well as from the discussions with my colleagues in the national research project Heritage of the First World War: Representations and Reinterpretations (2016-2018).

\section{NOTES}

1 The article is part of the research project Dediščina prve svetovne vojne: reprezentacije in reinterpretacije (Heritage of the First World War: Representations and Reinterpretations) (J6-7173) funded by the Slovenian Research Agency (cf. Jezernik \& Fikfak 2018).

2 A notable example of this pacifist and humanistic approach to the Isonzo Front is the excellent exhibition Človek in vojna (Man and War), prepared by Karla Kofol, an ethnologist and curator at the Tolmin Museum. The exhibition won the Slovenian Ethological Society's Murko Award in 2016. Its focus is on the everyday life of soldiers, civilians, and society during the Isonzo Front. It does not include a single weapon. The exhibition is still open to the public at the Memorial to the Defenders of the Slovenian Homeland on Cerje Hill above the town of Miren, Slovenia.

3 The Twelfth Battle took place in a rugged mountainous area of the Julian Alps. In tourism discourse it is often advertised as the "greatest highland battle in human history". It was the only attack by the Austro-Hungarian and German army on the Isonzo Front. It took place on October 24, 1917, and was a complete surprise for the Italian army. In only four days the Italians were badly defeated and the frontline was pushed as far as the Piave River, $170 \mathrm{~km}$ west of the Soča Valley. The battle claimed the lives of at least thirteen thousand Italian soldiers and five thousand soldiers on the Austro-Hungarian and German side (STA 2017).

4 The Kobarid Museum was granted the highest Slovenian museum award in 1992, was nominated for European Museum of the Year in 1993, and received the Council of Europe Museum Prize for 1993 in Strasbourg. 


\section{REFERENCES}

Bajuk Senčar, Tatiana 2013. Načrt upravljanja Triglavskega narodnega parka in kultura dediščinskih praks. [The Triglav National Park Management Plan and the Culture of Heritage Practice.] Traditiones, Vol. 42, No. 2, pp. 9-25. https://doi.org/10.3986/ Traditio2013420201.

Baldwin, Frank \& Sharpley, Richard 2009. Battlefield Tourism: Bringing Organized Violence Back to Life. In: Richard Sharpley \& Philip R. Stone (eds.) The Darker Side of Travel: The Theory and Practice of Dark Tourism. Bristol \& Buffalo \& Toronto: Channel View Publications, pp. 186-206.

Cimprič, Željko 2017. Odprl se je pekel. [The Hell Has Opened.] Delo: Sobotna priloga, October 20, pp. 12-13. Available at https://www.delo.si/sobotna/odprl-se-je-pekel. html, last accessed on 27 July 2018.

Dapit, Roberto \& Ivančič Kutin, Barbara \& Ledinek Lozej, Špela (eds.) 2015. Le collezioni uniscono: Collezioni ethnologishe, tradizione orale e turizmo culturale fra Alpi e Carso / Zbirke povezujejo: Etnološke zbirke, ustno izročilo in kulturni Turizem med Alpami in Krasom. [The Collections Connect: Ethnological Collections, Oral Tradition and Cultural Tourism between the Alps and Karst.] Udine: Universita degli Studi di Udine, Dipartimento di Lingue e Letterature Straniere.

Fikfak, Jurij \& Bajuk Senčar, Tatiana 2015. Triglavski narodni park: Akterji, strategije, problemi, rešitve. [Triglav National Park: Actors, Strategies, Problems, Solutions.] Traditiones, Vol. 44, No. 1, pp. 7-27. http://dx.doi.org/10.3986/ Traditio2015440101.

Gorgus, Nina 2017. The "Sleeping" Collection or How Collections Survive in Museums. In: Jože Hudales \& Tanja Roženbergar (eds.) Collecting and Collections in Times of War or Political and Social Change: COMCOL Annual Conference, Celje 2014. Ljubljana: ZZFF, pp. 131-141.

Hudales, Jože 2015. Dediščine Triglavskega narodnega parka v muzejih in muzejskih zbirkah. [Heritages of Triglav National Park in Museums and Museum Collections.] Traditiones, Vol. 44, No. 1, pp. 59-85.

Hudales, Jože \& Roženbergar, Tanja (eds.) 2017. Collecting and Collections in Times of War or Political and Social Change: COMCOL Annual Conference, Celje 2014. Ljubljana: ZZFF.

Jezernik, Božidar \& Fikfak, Jurij (eds.) 2018. Cultural Heritage of the Great War. Traditiones, Vol. 47, No. 1. DOI: 10.3986/Traditio20184701.

Kaučič, Andreja 2017. The Attitude of the New Authorities Toward Cultural Heritage in Slovenia After the Second World War. In: Jože Hudales \& Tanja Roženbergar (eds.) Collecting and Collections in Times of War or Political and Social Change: COMCOL Annual Conference, Celje 2014. Ljubljana: ZZFF, pp. 227-240.

Kofol, Karla 2015. Privatne zbirke Gornjega Posočja ter njihovo sodelovanje s pooblaščenimi muzeji in pristojnimi institucijami. [Private Collections of the Upper Soča Valley and Their Cooperation with Accredited Museums and Institutions in Charge.] In: Robert Dapit \& Barbara Ivančič Kutin \& Špela Ledinek Lozej (eds.) Le collezioni uniscono: Collezioni ethnologishe, tradizione orale e turizmo culturale fra Alpi e Carso / Zbirke povezujejo: Etnološke zbirke, ustno izročilo in kulturno Turizem med Alpami in Krasom. Udine: Universita degli Studi di Udine, Dipartimento di Lingue e Letterature Straniere, pp. 271-281. 
Koren, Tadej 2015. The Walk of Peace from the Alps to the Adriatic: A Guide along the Isonzo Front. 2nd ed. Kobarid: Ustanova Fundacija Poti miru v Posočju.

Košir, Uroš 2014. Arheologija in prva svetovna vojna. [Archaeology and the First World War.] Apokalipsa, No. 185-186, pp. 102-128. Available at http://www.academia. edu/9721373/Arheologija_in_prva_svetovna_vojna, last accessed on 27 July 2018.

Kozorog, Miha \& Poljak Istenič, Saša 2013. Triglavski narodni park v horizontu rekreacijskega avanturizma. [Triglav National Park and Recreational Adventurism.] Traditiones, Vol. 42, No. 2, pp. 105-126. https://doi.org/10.3986/ Traditio2013420206.

Kravanja, Boštjan 2014. Selling and Sharing Culture: On Relations between Cultural Heritage, Nature Conservation and Tourism Development Institutions in the Upper Soča Valley, Slovenia. Narodna umjetnost, Vol. 51, No. 1, pp. 89-112. https://doi.org/10.15176/vol51no105.

Kregar, Tone 2017. Missing the Years: The Memory of World War I at the Museum of Recent History Celje. In: Jože Hudales \& Tanja Roženbergar (eds.) Collecting and Collections in Times of War or Political and Social Change: COMCOL Annual Conference, Celje 2014. Ljubljana: ZZFF, pp. 143-151.

Kuhar, Miha 2017. Ni bil čudež. To je bila zmaga idej, morale in fizične moči. [It was not a Miracle. This was the Victory of Ideas, Morality and Physical Power.] Delo: Sobotna priloga, October 20, p. 15. Available at https://www.delo.si/sobotna/ ni-bil-cudez-to-je-bila-zmaga-idej-morale-in-fizicne-moci.html, last accessed on 27 July 2018.

Matás, Gonzalo Linares \& Roberts, Marco \& Telfer, Nicholas 2014. The Archaeology and Anthropology of the First World War: A Multidisciplinary Approach for the Study of a Global Conflict. The Historian, Vol. 3, No. 3, pp. 19-24. Available at https:// www.researchgate.net/publication/272164593_Archaeology_and_Anthropology_ of_the_First_World_War, last accessed on 27 July 2018.

Meijer-van Mensch, Léontine 2017. Profiling and Reflecting on Collections and Collecting. In: Jože Hudales \& Tanja Roženbergar (eds.) Collecting and Collections in Times of War or Political and Social Change: COMCOL Annual Conference, Celje 2014. Ljubljana: ZZFF, pp. 19-27.

Močnik, Blaž 2017. Rommel teh krajev ni osvobajal, ampak je prišel le izpolnit svojo nalogo. [Rommel Did Not Liberate These Places, He Only Came to Do His Job.] An Interview with a Historian Blaž Torkar. Delo: Sobotna priloga, October 20, pp. $14-15$.

Poljak Istenič, Saša (ed.) 2015. Kulturna dediščina med Alpami in Krasom: Vodnik po zbirkah. L'eredità culturale fra Alpi e Carso: Guida alle collezioni. [Cultural Heritage between Alps and Karst.] Ljubljana: Založba ZRC.

Saunders, Nicholas J. 2004. Material Culture and Conflict: The Great War, 1914-2003. In: Nicholas J. Saunders (ed.) Matters of Conflict: Material Culture, Memory and the First World War. London: Routledge, pp. 5-25.

Saunders, Nicholas J. 2010 [2007]. Killing Time: Archaeology and the First World War. Stroud: The History Press.

Saunders, Nicholas J. \& Faulkner, Neil \& Košir, Uroš \& Črešnar, Matija \& Thomas, Sîan 2013. Conflict Landscapes of the Soča/Isonzo Front, 1915-2013: ArchaeologicalAnthropological Evaluation of the Soča Valley, Slovenia. Arheo, Vol. 30, pp. 47-66. Available at http://www.academia.edu/6118571/, last accessed on 27 July 2018. 
Scheller, Mimi \& Urry, John 2004. Places to Play, Places in Play. In: Mimi Scheller \& John Urry (eds.) Tourism Mobilities: Places to Play, Places in Play. London \& New York: Routledge, pp. 1-10.

Seaton, Tony 2009. Thanatourism and Its Discontents: An Appraisal of a Decade's Work with Some Future Issues and Directions. In: Tazim Jamal \& Mike Robinson (eds.) The SAGE Handbook of Tourism Studies. Los Angeles: SAGE, pp. 521-542.

Sedmak, Drago 1997. Prva svetovna vojna. [The First World War.] In: Zdravko Likar \& Alenka Raspet \& Željko Cimprič (eds.) Kobarid. Kobarid: Kobariški muzej, pp. 85-118.

STA 2017. Soška fronta $v$ številkah. [The Isonzo Front in Numbers.] Slovenian Press Agency (STA). Available at https://www.sta.si/soska-fronta/v-stevilkah, last accessed on 27 July 2018.

Svoljšak, Petra 1993. Prva svetovna vojna in Slovenci. [The First World War and the Slovenians.] Zgodovinski časopis, Vol. 47, No. 4, pp. 547-562.

Svoljšak, Petra 2017. Kakor da se je peklo zaklelo, da mora pokončati vse, čemur je prizanesla vojska. [As If the Hell Has Been Put Under the Spell, That It Has to Destroy Everything That the War Had Spared.] Delo: Sobotna priloga, October 27, pp. 14-15. Available at https://www.delo.si/sobotna/kakor-da-se-je-peklo-zakleloda-mora-pokoncati-vse-cemur-je-prizanesla-vojska.html, last accessed on 27 July 2018.

Walk of Peace 2017. About the Foundation. Available at http://www.potmiru.si/eng/ the-walk-of-peace-from-the-alps-to-the-adriatic, last accessed on 27 July 2018. 


\title{
FROM THE EDITORIAL BOARD
}

\section{CONTINUITY AND REVITALISATION \\ IN SACRIFICIAL RITUALS \\ BY THE EASTERN UDMURT}

\section{PART II. COLLECTIVE SACRIFICIAL RITUALS BY THE BASHKORTOSTAN UDMURT: REVITALISATION AND INNOVATION}

\section{Eva Toulouze}

Institut National des Langues et Civilisations Orientales, Paris, France Department of Ethnology, University of Tartu, Estonia

e-mail: evatoulouze@gmail.com

\section{Ranus Sadikov}

Department of Ethnography, Kuzeev Institute of Ethnological Research

Ufa Science Centre of the Russian Academy of Sciences, Russia

e-mail:kissapi@mail.ru

\section{Laur Vallikivi}

Department of Ethnology, University of Tartu, Estonia

e-mail: laur.vallikivi@ut.ee

\section{Liivo Niglas}

Department of Ethnology, University of Tartu, Estonia e-mail: liivo.niglas@ut.ee

\section{Nikolai Anisimov}

Department of Folkloristics, Estonian Literary Museum, Estonia

e-mail: nikolai.anisimov@folklore.ee

\begin{abstract}
This is the second part of an article that focuses on a marginal Udmurt group living in Bashkortostan, which has retained, in a Muslim environment, its original Udmurt religious practice. In some places, in spite of decades of antireligious Soviet policy, the Udmurt were able to pursue their traditional rituals, thus warranting full continuity of their practice. In other places, the tradition was discontinued for some longer or briefer periods. But everywhere there has been a revival at the end of the twentieth and beginning of the twenty-first century.
\end{abstract}


The aim of this article, which is based on the authors' fieldwork in one district, is to examine these processes and analyse them. In this second instalment, we analyse the changes that were introduced in the revitalisation process in several dimensions of religious practice: the use of sacred space, the role of different actors, the proceedings of the rituals, the transmission of the prayers, the costume of the priests, the behaviour of the participants.

Keywords: agrarian religion, anti-religious policy, diaspora, prayers, religious practice, ritual, sacrificial ceremonies, sacrificial priests, transmission, Udmurt, village community

In the first part of the article ${ }^{1}$, we presented religious traditions of the Eastern Udmurt in the Tatyshly district, Bashkortostan. We insisted on the importance of continuity in the religious practice of this particular group of the Eastern Udmurt. Now we will focus on the revitalisation process that has been going on since the $1990 \mathrm{~s}$, and the innovations that have been introduced into Udmurt religious practice.

Herein we examine the latest developments of the different aspects of Tatyshly Udmurt's religious practice: the ritual cycle, actors, sacred places, prayers and sacrificial rituals, participants.

We have already mentioned that the Tatyshly Udmurt were organised in two religious groups and that their collective ceremonies were structured in seasonal cycles. Let us now observe how the spring cycle is functioning today.

\section{RECENT DEVELOPMENTS: THE CYCLE NOWADAYS}

In 2016, the situation of the ceremonial cycle was the following in both groups:

- In the right bank group (or the Vil'gurt group), all the villages including the district centre held their village spring ceremonies and gathered for the mör vös’2 in Vil'gurt one week later. The winter tol mör vös' was held also in Vil'gurt, with three villages in attendance (in 2016).

- In the left bank group (or the Alga group), all the villages held their village spring ceremonies on the first Friday of June in Nizhnebaltachevo (with Alga), in Verkhnebaltachevo (with Dubrovka), in Kyzylyar (with Tanypovka), in Bigineyevo (with Utar El'ga, where it was revived only in 2012), and in Starokalmiyarovo (with Petropavlovka). One week later, all these villages - with the exception of Starokalmiyarovo - organised an intermediate ceremony, called Bagysh vös'. This is a peculiar feature to be noted: while in the right bank group the three villages' ceremony has been seemingly once and for all eliminated, in the left bank group the 
intermediate ceremony has grown so much that almost all the villages attend. When we attended the Bagysh vös' in June 2015, Bigineyevo had just joined for the first time. This shows that the population of the left bank villages expresses a thorough need for intense religious activity, for each ceremony requires a real involvement of the population: people donate crops, butter and money, which allows to buy a ewe; it also demands hard physical involvement from the sacrificial priests and the helpers. One week later, all the villagers then gather for the mör vös' in Alga. In winter, in December, they hold both the tol Bagysh vös' and tol mör vös'. Until recent times, no winter village ceremony had been revived, but in December 2016 we heard about a village winter ceremony in Starokalmiyarovo. This is to be investigated in our forthcoming fieldwork.

So there is, as a result of both Soviet adaptation strategies and post-Soviet revival choices, an increasing gap between the Vil'gurt and Alga groups.

\section{RECENT DEVELOPMENTS: THE ACTORS}

Since the end of the 1980s, the Tatyshly Udmurt have started a process leading to a massive revival of their religious practice. It is important to emphasise that nowhere here they started from scratch. In many places ceremonies were already held, with sacrificial priests and confirmed helpers and sacred places functioning. In other places, the memories were still fresh in most of the people's minds, and the sacred places were still there.

These processes were launched in the ritual subgroups of the Tatyshly district and in all the other districts with an Udmurt population. But their materialisation was related to the group's peculiarities and traditions. The starting point, that is, the level of preservation of the rituals in both groups, differs: the right bank group - the Vil'gurt group - had somewhat simplified the rituals and loosened some rules, as compared to the Alga group (the left bank group), which seems to have retained more complex rituals and somewhat stricter rules.

Before delving into the evolution of the rituals, we shall now concentrate on the actors of the revival and try to evaluate their respective roles.

\section{The role of sacrificial priests}

The first actors to be mentioned are the sacrificial priests, without whom neither revival nor ceremonies would exist. In the traditional religion of the Udmurt, the sacrificial priest was a member of the rural community, who had to fulfil 
certain requirements: he had to be married, to be respected in the community, to know the rituals and prayers, and to be over forty years old. ${ }^{3}$ Usually, among the Eastern Udmurt, he was officiated until his death, and then a new priest was elected (Sadikov 2008: 190). Older sources inform us that there were different categories of priests, all elected by the village assembly, officiating at the collective sacrificial ceremonies: the vös'as' (Udm. вӧсясь) or kuris'kis' (Udm. куриськись, "the one who prays"), the tylas' (Udm. тьллась "the one who burns") and the partchas' (Udm. napmyacb, "the one who cuts"). ${ }^{4}$

These distinctions are not relevant anymore. Nowadays, there are vös'as' (sacrificial priests), who take care of the entire ceremony, and they are assisted by helpers whose tasks are assigned by the vös'as'. As we can see, there has been a change in the role of the sacrificial priest but for lack of information we are not able to pinpoint the moment of the change. Sometimes Nazip Sadriev (the previous vös'as in Balzyuga) uses the word partchas', but without meaning anything else than helper. We may only presume that during the Soviet period, when it became more difficult to find people wishing to take over the tasks of a sacrificial priest, the different tasks melted into a single one.

Anyhow, the acting sacrificial priests were a significant initiative force to reckon with. The name of Nazip Sadriev has already been mentioned several times, and the time has come to introduce him properly, because for a long time he has been one of the cornerstones of the religious practice in the Vil'gurt group, and in Bashkortostan on a wider scale. Nazip Sadriev was very young when he started to observe the rituals led by the sacrificial priests. He started his "professional" activity as an assistant, and then as a main priest, in 1954, when he was only 24 years old (Toulouze et al. 2017). Actually this was exceptional, for in the olden days the sacrificial priests had to be older men, at least 40 years old. But the times were difficult, and there was no choice. He learnt the prayers from the older priests, listened to them and memorised the texts, which was the traditional way to transmit oral knowledge. Until 2010, Nazip Sadriev held the village ceremony (gurten vös') in his own village every year and was the head priest in the mör vös' in Vil'gurt. Thanks to his efforts, another ceremony was revived, the winter mör vös', which had been discontinued in the Soviet times. According to tradition, all the right bank villages are supposed to be represented, but in practice, when we attended this ceremony in December 2016, there were only sacrificial priests from four villages. ${ }^{5} \mathrm{He}$ is the one whose perseverance allowed to re-establish ceremonies in all the villages of the right bank of the Yug River, for there the village ceremonies had been forgotten in several villages - except Vil'gurt and Bal'zyuga. ${ }^{6}$

$\mathrm{He}$ "appointed" and trained sacrificial priests in the villages, all respected men usually from priests' families, which means that among the ancestors there 
were priests, who taught them or who wrote the words of the prayers. Nazip taught them the ritual acts while they participated in the mör vös' under his leadership. In some cases, he went to different villages himself and trained the local sacrificial priests. ${ }^{7}$

The appointment of priests and their training are serious issues. As the informers observed, usually, in former times, the priests themselves prepared their replacement: they detected smart children and took them to the ceremonies, where the latter learnt the rituals and the prayers. Most probably they attempted to teach their own children; so did Nazip Sadriev, who endeavoured to teach his own son Mingarai. But the latter stubbornly refused to become a sacrificial priest, although he always helped the ceremony organisers and spent the whole day chopping wood during the preparation of the sacrificial porridge. So Nazip had to find someone else.

On the left bank of the Yug River, the ceremonies were performed in most of the places, so the revival was more limited and easier to achieve. Almost everywhere they had already trained sacrificial priests, and the most important of them, Evgeniy Adullin, occupies a leading position in the agricultural enterprise Rassvet ('Dawn'), for he is its chief accountant. Here the ceremonies were performed constantly even in the Soviet period. The main role in maintaining the religious traditions is occupied by the local sacrificial priests, for whom it is important to keep alive all the ceremonies related to the site.

\section{The role of officials}

It is necessary to emphasise the role of Nazip Sadriev in the revival of the sacrificial ceremonies of the Eastern Udmurt, because the existence of a strong priest contributes to this. Without a priest any kind of revival would have been much more unlikely. However, in the 1990s and later, Nazip was very strongly supported by the officials, leaders at the local level and at the level of the main employer in the district, the agricultural enterprise Demen, successor of the local kolkhoz.

Since the beginning of the 1990 s, both the agricultural enterprise Demen, through its leader Rinat Galyamshin (an Udmurt), and the local administration have started giving active support to the revival of religious rituals. They organised a Vös' kenesh (Вӧсь кенеш), a religious council, which dealt with the organisation of ceremonies. One of the active participants of the religious revival was the former head of the kolkhoz, Rafik Kamidullin ${ }^{8}$, who published articles on this issue in the local Udmurt paper Az'lan' (Азьлань). In 1993 the sacred place was fenced in and in 1994 a building was erected, a "house of prayer" (вӧсь корка), for the money given by the district and the local administration, 
as well as offerings from the population of the villages participating in the Vil'gurt mör vös' (Kamidullin 1994). It is a log building, similar to a dwelling house (called vös' korka (вӧсь корка) in Udmurt), which has no ritual function but makes the ceremonies easier and more convenient for the priests, helpers and attendants to conduct, particularly in wintertime. It is important not to mix it up with the kuala, the only sacred building in the Udmurt culture, the equivalent of a shrine, which is not used in ritual practice anymore, but retains a high load of sacredness and magical power. These "houses of prayer" are not ritual sacred buildings. They are only meant to increase the comfort of the people both working at and attending the ceremonies, where cult paraphernalia is kept, and where in the wintertime ritual food is distributed.

In 1996 an Udmurt organisation was founded, called the National-Cultural Centre of the Udmurt of Bashkortostan, ${ }^{9}$ a kind of national movement assembling the Udmurt from different districts in Bashkortostan, with an office established in Vil'gurt, and after this even more attention was given to the religious events. In the summer of 1998, the chairman of the organisation, the abovementioned Rinat Galyamshin, decided to invite to the mör vös' in Vil'gurt representatives of all the Bashkortostan districts with Udmurt communities, as well as guests from the Kuyeda district in the Perm Krai and from Udmurtia. This religious gathering thus achieved a high status at the level of the Republic of Bashkortostan.

Rinat Galyamshin is an extraordinarily strong leader, especially for an Udmurt - the Udmurt having the stereotypical reputation of usually being meek. He has much authority not only within his community, but at the district level at the very least, certainly partly because of the outstanding economic results of the kolkhoz under his leadership. He was also the initiator of the Udmurt National-Historical Centre and held the leader's position until November 2015. Because of the health problems, he was then replaced by Salimyan Garifullin.

Galyamshin had a central role in the revival of the ceremonies in villages where they had faded. He picked up local leaders, whom he knew from the local responsibilities they had taken for years, and asked them to find in the population the descendants of former vös'as' and to have them take over these tasks. It is clear that in these villages, the initiative came from "above". But it reflected a real demand of the villagers. For example, in June 2015, with the support of Galyamshin, and of his son Rustem, who was then one of the leaders of Demen, the ceremony in Verkhnie Tatyshly, the centre of the district, was revived. The sacred place was situated not far from the old place of the mör vös'. Galyamshin had asked a former official, Rif Adisanov, to find a vös'as' and he in turn had asked Kabiok Badamshin, an old man from a priest's family, born in Vukogurt in 1932, to officiate. The ceremony had been somehow impro- 
vised, and as the organisers did not expect a wide attendance, they had chosen not to risk buying a ewe in June 2016. Yet, the attendance was unexpectedly enthusiastic, so the next year the village ceremony was fully performed, in a sacred place that had meanwhile been properly fenced in and where a small cabin had been built. This shows that the initiative from above is indeed not disconnected with the expectations of the wider population. This is particularly to be stressed as the district centre is not overwhelmingly an Udmurt centre: according to the 2010 census, the Udmurt constitute 13 percent in the village, where the majority of the population is Tatar and Bashkir, amounting to 80 percent (Toulouze \& Vallikivi 2015: 19).

On the left bank of the Yug River, the agricultural enterprise Rassvet ('Dawn') and especially its former head, Khanif Bamiev, also supported the development of religious practice in the villages through funding and practical help: the sacred place in Alga was fenced in the 1990s, and in 2005-2007 a "ceremony house" was built there. ${ }^{10}$ But still we have the impression that here the initiative from above is more limited and less material.

\section{RECENT DEVELOPMENTS: THE RENEWAL OF THE ACTORS}

\section{The sacrificial priests}

In every village, there are sacrificial priests, at least one, but most times two or more. Let us examine the situation in several villages, starting from the ones in which ritual continuity has been maintained.

In Bal'zyuga, the old priest appointed, as a replacement, a young man from a priest's family, Fridman Kabipyanov (born 1978). He is a music teacher. Fridman is married and respected in the village. But he was 32 when he was appointed, and this reminds us that Nazip himself was but 24 when he started, in the post-war context, when there were not enough older men. Thus, Nazip Sadriev has violated a traditional "law" in his choice of a successor. We may just infer that his own experience helped him to overcome a possible taboo, and that he made a choice of adapting to the contemporary world, where a young vös'as' may have good possibilities of attracting the younger part of the population.

In Vil'gurt, continuity according to the old rules was entirely respected, and it is the only village in the right bank group for which this can be said. One of the sacrificial priests is Rais Rafikov, born in 1948, a retired "mechanic"11, whose father was a vös'as'. When he was a boy, he attended several sacrifices with his father; he participated in private ceremonies and learnt both the ritual activities and his father's prayers. He started to lead ceremonies relatively late (in 
2012), but according to his words, he is currently training his son. ${ }^{12}$ The second priest in the village ${ }^{13}$ was, until his demise in autumn 2017, Salim Shakirov, born in 1948, a retired clerk, who was appointed on the advice of Galyamshin. He did not come from a family of priests, but was a capable organiser and was respected among the villagers. Both priests shared tasks harmoniously: Rais enthusiastically covered most of the ritual parts, while Salim occupied the function of the "host of the ceremony" (in Udm. vös' kuz'o (вӧсь кузё)), which means that he dealt with organisational and financial questions - gathering money and crops, buying the ewes, etc. After Salim's death, Rais resumed the traditional rules and appointed a "younger" man (around 60 years old), Zinnat Dautov, a former bus driver, whose father was a sacrificial priest. He is still learning his task.

In other villages revitalisation took different forms. After the demise of the older vös'as', nobody among the younger men took over, and the sacrifices were not performed anymore. Things started to change in the last decade, due to certain impulse and encouragement from the authorities. Aribash is an example of a lesser interference by Rinat Galyamshin, although he is from this village and this may have had some indirect impact. There, revitalisation was started by Aleksey Garaev (born in 1947, a retired teacher). However, our field research allows us to suggest that the first impulse came from his wife, Liliya Garaeva, also a former teacher. Liliya herself is from Bigineyevo and was brought up in a more "religious" family compared to most others. As a child, she attended ceremonies with her grandmother and, as a result, she became a good bearer of tradition. She is also an extraordinarily active woman, who feels concerned about community issues and even writes regularly in the local Udmurt-language weekly paper, Oshmes ('Source').

As animistic ceremonies are a male activity, there is almost no room for women. So Liliya acted through her husband Aleksey. Besides Aleksey, we have seen two other priests: Valeri Shaymukhametov, who attended the ceremony in 2015, and another one who was in poor health at the time. So there are in all three sacrificial priests, as many actually as the Udmurt clans living in the village (named poska, chudya, tuklya). ${ }^{14}$ Here the revival took a particular form: while there are two sacred places in the village - one close to the river and the village and the other farther away, on top of a hill - the village ceremony that was revived here is the keremet vös', whose traditions are followed until today - the participants are only men; they sacrifice rams, and pray with flatbreads kuarn'an' ("leaf-bread"). Interestingly, the prayer is not uttered loudly. ${ }^{15}$ At the same time, the sacrificial priest's wives play an important role in the organisation of the ceremony and in its proceedings: they are present since the very beginning, they cook, they pray on their knees right behind the priest, 
and they even dress their husbands. It is the only place in which we have seen women as active and it can only be explained by Liliya's active personality, for the keremet ceremony traditionally leaves no place for females. What is also interesting to mention in regard to this ceremony is that the ritual follows the place's original function, it is somehow attached to the place, while the overall function of the ceremony has changed: this ceremony is considered as the village spring ceremony, allowing Aribash to attend, on the following week, the mör vös' in Vil'gurt (for more details, see Toulouze \& Niglas 2017).

Another example is Yuda, where the vös'as', at the moment, is Zakaryan Nigamatyanov (born in 1949, a retired "mechanic"). In his childhood, he was taken to the ceremonies along with adults; some fifteen to twenty years ago, he started praying with his friends at the mör vös' in Vil'gurt, and about five years ago, he revived the village ceremony in his village. According to his words, he was asked by the old men of the village to officiate as a vös'as'.

The last example we can mention in the Vil'gurt group is Vukogurt ${ }^{16}$, where the ceremonies had also been discontinued long ago. Here, Galyamshin's role is also very clear: he contacted Saifudtin Nuriakhmetov, who had been a local leader, and asked him to find a sacrificial priest. The one he suggested was quite young, a worker at the local brickworks.

In the other, the Alga group, family continuity has been preserved. Here, the vös'as' are usually descendants of former vös'as', even if they were not able to receive training from their ancestors. In Nizhnebaltachevo, the priest is Evgeniy Adullin (born in 1965). Thanks to his excellent knowledge of the profession's technicalities, he is considered as the "senior" priest in the Alga group. He has been chosen as a priest because his grandfather was a priest, although he was not the one to pass on his knowledge to him. He uses Nazip's prayer. His cousin, Zakhar Adullin, a retired teacher, is also well trained in ritual knowledge: he learnt a prayer from an older vös'as', and was able to recite it to us in June 2016, chanting it in a peculiar recitativo: he told us that formerly they prayed differently and he wanted to show us how. But Zakhar does not act as a vös'as', probably because of personal problems (divorce, drinking problems, etc.). There are other experienced vös'as' in this group, who learnt their prayers from their grandfathers. One is Verkhnebaltachevo's sacrificial priest Vladimir Khazimardanov (born in 1964), whose grandfather Islam was recorded by Hungarian scholars Gábor Bereczki and László Vikár in 1973, and who has been active as a vös'as' for twenty years. ${ }^{17}$ His elder brother Boris has been lately acting as a sacrificial priest in Kyzylyar.

In Bigineyevo, it was Galyamshin's assistant, Tatiana Shaybakova, the then director of the Udmurt Centre, who contacted an active man in the village, Rinat Usmanov, who is half Udmurt and half Bashkir. He was the one 
who led us to the present vös'as', Zimnat Shartdinov, born in 1952, a retired tractor driver, who now works as a blacksmith.

We have not attended many village ceremonies in this group: in Nizhnebaltachevo in $2016,{ }^{18}$ with Evgeniy Adullin, whom we have already followed several times, ${ }^{19}$ and in Starokalmiyarovo in 2018, where the priests are all relatively young, between 50 and 65 years old, but have not benefitted from continuity with their predecessors. But in this group at the tol Bagysh vös' in December 2013 we noticed that some younger helpers were "promoted" to sacrificial priests, in the absence of the older ones who were ill. They prayed with the older sacrificial priests and wore the priest's costume. How did it happen?

The answer to this question leads us to a new category of actors, which is clearly a product of the revitalisation process.

\section{The vös' kuz'o and the vös' korka utis'}

Today there are new categories of actors, which, according to our sources, did not exist formerly. The first one is the category of the so-called vös' kuzo (вӧcb $\kappa у з \ddot{e})$, "the host / master of the ceremony", who deals with all the questions of finance and organisation allowing to perform a ceremony. This category exists in both groups of the Tatyshly district, although not everywhere.

Let us start with the left bank group, where, as we have seen, there was no actual need to revive village ceremonies, as none of them had faded. There was also no need to find new sacrificial priests to start afresh.

There emerged a strong personality, Garifulla Garifanov, born in 1947, a retired former chairman of the rural council (soviet), who is ordinarily called Farkhulla. One decade ago, he was asked by the villagers to take care of the ceremonies. He took the initiative to organise the general ceremonies Bagysh vös' and mör vös', as well as the village ceremony gurten vös'. He leads the fund-raising and gathering of sacrificial animals. As he has enormous authority among the priests, he organises their activities, although he has no ritual functions at all. ${ }^{20} \mathrm{He}$ is the one who appoints the priests who are supposed to pray at the multiple villages' ceremonies: in the example above, he is the one who decided to allow Yasha, a young helper from Verhnebaltachevo, and Evgeniy, also a young helper from Alga in his twenties, to pray with the older sacrificial priests. True enough, after this episode, we have never seen them again in the position of vös'as'. But we have come to realise that Farkhulla is implementing long-term "human resources policies", preparing these two young men to step into the position at the demise of an older priest. Thus, in this case, his personal involvement and influence go much further than to organise the buying of sacrificial animals and transportation to the sacred places. 
In the right bank group, the function of vös' kuz'o is much more developed precisely because of the need to organise the revival of faded ceremonies. In Vil'gurt, in the 1990s, the organiser of the ceremonies was the abovementioned Rafik Kamidullin. Later on, Vil'gurt's second vös'as', the one selected by Galyamshin, Salim Shakirov, acted as an organiser, probably in regard to his abilities and his contacts' network. After his death, the main vös'as' Rais took over his tasks. In other villages, the authoritative men who were asked to initiate the revival by looking for potential sacrificial priests continued helping them and organising the ceremonies in which they officiated. Thus, the function of vös' $k u z^{\prime} O$ is one of the consequences of the revitalisation process.

With the building of "ceremony houses" both in Vil'gurt and in Alga there emerged a new category of people connected with the house: the vös' korka utis' (Udm. вӧсь корка утись), the "wardens of the house of prayer". There used to be such houses called tarlau korka at some sacred places in the past, where priests could spend the night when there were big ceremonies far from the villages (Sadikov 2008: 46).

In Alga, there is no particular person responsible for the house and Farkhulla takes care of it as he does of the rest. But in Vil'gurt, this function exists and it is fulfilled by Khabrislam Khabibyanov (born in 1933), whose house happens to be close to the sacred place. His responsibility includes overlooking the territory of the sacred place and "the house of prayer", the keys to which he keeps. The cauldrons and other items for the practice were often replaced by his wife, who attended the ceremonies and opened the house. As she died in 2015, his daughter has overtaken her parents' responsibilities. In 2018, nevertheless, the old man attended the ceremony in person.

\section{RECENT DEVELOPMENTS: SACRED PLACES}

As we mentioned earlier, the Eastern Udmurt villages had several sacred places and buildings, with differentiated usages. Nowadays, the ones most often used are those in which the ceremonies we concentrate on in this article take place: they are called "place of ceremony, place of sacrifice" (Udm. вӧсяськон инты or вӧсяськонтӥ / куриськон инты ог куриськонтӥ), without any particular reference to the abstract notion of sacredness (Toulouze \& Vallikivi 2016: 147). The other places have been abandoned, and they host no rituals. The location of many of them is still preserved in the memory of most of the people who attempt to keep the wholeness of these sites intact as much as possible: people avoid visiting them, using them for ordinary goals, desecrating them. There are many stories circulating about the violation of these places and the dreadful consequences they elicit: it is an interesting issue that deserves more thorough investigation. 
The agrarian sacred places share some features: they are usually in a beautiful site and close to a spring or another water body, from which during the ceremonies the helpers take water. In the centre, there is a fireplace where sacred porridge is cooked and where blood and bones are offered and burnt, as well as tables used for placing crops and butter on, and for sorting meat.

In some cases, and not only because of the need for secrecy in the Soviet times as mentioned above, there has been a change in the sacred places: those used nowadays are not always the old ones. For example, if a sacred place is situated far from the village or has been damaged by economic activity, another place may be selected for sacrificial ceremonies, as it has happened in Vukogurt. The first place was situated on a hill in a beautiful landscape, but it was far from the village and without any water nearby; therefore, the sacred place was brought nearer to the village, and it encompasses a spring. The distance from the village is also the reason why roughly one decade ago the sacred place was changed in Nizhnebaltachevo. At the moment it is within the village borders and close to a spring. In order to give the new place its sacredness, a ritual of "transfer" must be accomplished. Therefore, with a prayer asking Inmar not to get angry, they transport coals and stones from the former fireplace. If it is not possible to find the former fireplace, they bring only soil.

A new phenomenon that deserves to be emphasised is the fencing, which characterises the last years. While all the keremet places were traditionally fenced in, it was not the case with the other places before the revival. Most of them were not marked at all and today this is still the situation for many of them outside the Tatyshly district. One of the first signs of revival was that the authorities started to pay attention to the sacred places and to fence them. It is one of the manifestations of the new public status of religious practice. So, we may assert that all the agrarian sacred places used in the Tatyshly district have been fenced in today. In this regard, the Tatyshly district has shown a way that, according to our observations, is being followed elsewhere.

This may have partly been connected with the particular status of these places. Even if sacred places (except the keremet ones) were not seen as dangerous per se, their desecration could have been accompanied by punishment. Therefore, they were not visited on ordinary days and adults explained to children where they were situated, so that the latter would not desecrate them by chance. Fencing protects the place from undesired visits both by humans and by livestock. Outside the Tatyshly district we have heard sacrificial priests emphasising the need for fencing: in Asavka, for example, the sacrificial priest Vladimir mentioned that in his village, where only half of the population is Udmurt, youngsters use the beautiful sacred place as a location for drinking and carousing. This issue was discussed in a round table organised by the 
Udmurt Historical-Cultural Centre ${ }^{21}$ the organisation that manages Udmurt cultural life, together with us, with invited sacrificial priests as well as with local leaders, and we all agreed that fencing was necessary everywhere. Some even proposed to put out signs informing about the sacredness of the places.

The sacred places in Vil'gurt and Alga have become places for wider ceremonies, which gives them a particular status, confirmed by the presence on their territory of vös' korka, a "prayer house". We have seen no other buildings in the sacred places of the Tatyshly district. These are log houses, built like living houses, where cult paraphernalia is kept, and where in winter ritual food is distributed. In the house in Alga, there is a stove, tapestries donated by the members of the community decorate the wall, and the facade is also decorated with Udmurt ornaments. In Vil'gurt, where there is no stove (but the priest Rais wants to have one built), there are exhibition stands with explanations about the history of the sacred place, of the revitalisation of the ceremonies as well as a paper copy of Nazip Sadriev's "World Tree Award". It was recently carpeted and a tapestry was hung on the wall.

Yet another interesting development should be mentioned. While in both groups the sacred places are fenced in, there was, until 2016, a big difference between sacred places in Alga and Vil'gurt. In Alga as in some other sacred places of the same group (for example in Starokalmiyarovo) there is actually a double fence: within the territory encompassed by the first fence, there is both the prayer house and a space with benches. This space is separated from the most sacred area by another fence, which encircles the sacrificial space. Only religious specialists are allowed on these grounds, especially women are not welcome, and they have to give their offerings to the vös'as' over the fence. But we have also seen sacrificial priests from other villages respectfully refrain from entering. ${ }^{22}$ Eva is only occasionally allowed inside the fence ${ }^{23}-$ or, more precisely, invited inside, although clearly not all the local women are aware of the taboo. In Vil'gurt, on the contrary, no internal fence or any kind of other limitation marked the sacred territory. Eva could move around, be close to the fireplaces and the cauldrons, and even to the place where the sacrificial priests prayed. Other women brought their breads there personally. Yet, by December 2016, things had changed. An internal fence had been built around the area where the fireplaces and the table were situated. The poles to which the participants were supposed to tie the towels they brought as offerings remained outside the fence. The vös'as' Rais said that he intended to implement a more severe approach, and to forbid the entrance to any outsider. It is not very probable that there could be any influence from the other bank neighbours. Rais has been connected to rituals since he was a boy and he probably remembers the way things used to be. He is thus taking initiative to increase the feeling 
of sacredness through taboo. This is a very interesting trend that deserves to be followed. In 2018 we had the opportunity of testing this new approach. Rais personally invited Eva inside, while as before and as in the Alga group, the cameraman could follow and film within the sacred area. Clearly, for the priests who are now accustomed to our presence, we are not the outsiders the fence is supposed to keep off.

\section{RECENT DEVELOPMENTS: RITUALS AND PRAYERS}

How much has the revitalisation process affected the ritual itself? Due to lack of available research, we have a limited understanding of all the adaptation processes that rituals went through in the Soviet period. We have remembrances of older participants, who are usually quite confused about the timetable. We shall, in the following chapter, analyse the data available to us.

\section{The time of the rituals}

Actually there have been substantial changes in the setting of the moment of the ritual. According to our informant in Aribash, formerly the days of the ceremonies used to be established according to the phases of the moon, and there was a regular order to be followed: the first villages to organise their ceremony were those on the lower course of the river and the order followed the course up the river (Sadikov 2008: 192). Today, none of these rules are followed any more. All the village ceremonies are held on the same day.

\section{Ritual costume}

During the ceremony, the priest is identified by a particular costume. This costume has changed throughout time. At the beginning of the twentieth century, as we know from older photographs, the priests wore a white caftan called shortderem (Udm. шортдэрел), and had wide belts called kuskertton (Udm. кускерттон). On their head, they wore a white felt bonnet wrapped in a white towel, and they had new bast shoes on (Sadikov 2008: 190). At that time, the shortderem was not only the costume of the priests: all the Eastern Udmurt wore this attire to attend religious ceremonies (Sadikov \& Mäkelä 2009: 262-263; Sadikov \& Hafeez 2010: 96), and this is still remembered by elderly women. ${ }^{24}$

Gradually, over the span of the twentieth century, homespun clothes went out of use and the shortderem was seen as a costume for priests. But nowa- 
days only few samples of old shortderem are preserved: some are still owned by priests, but older women keep them as well. ${ }^{25}$ The disappearance of the caftan was also encouraged by the fact that it was part of the burial costume: the older Udmurt who own a shortderem ask to be buried in it in order to enter the world beyond dressed as Udmurt. Because of the gradual disappearance of the shortderem, they have been replaced, for the sacrificial priests, with white ${ }^{26}$ ordinary working or medical smocks. The smocks used for the rituals are not used for anything else. They are washed every year before any new ceremony.

The renewal of the ceremonies allowed the emergence of a new demand for ritual caftans. At the beginning of our systematic fieldwork in June 2013, the priests we saw used either white (or light blue) smocks; only the Vyazovka vös'as' had an old shortderem. Things started to change very quickly, the same year, in the Alga group. In the autumn of 2013, the Alga group made special costumes from white fabric with vertical stripes, reminding of the shortderem in some way, only with much wider stripes (Toulouze 2016: 20). The funding for the fabric and the tailoring was provided by the local agricultural enterprise Rassvet. They have a whole collection of smocks, which are used by whoever is in charge of the prayers.

We have to admit that we have interfered in this process, when we presented our friend, the young Bal'zyuga vös'as' Fridman, with a contemporary shortderem he used in his ceremonies during the last years.

Thus, at the moment, there are four ritual costumes used in parallel in the Tatyshly district: the Soviet-time ordinary white smocks, the old shortderem, the new one, and the Alga ad hoc costume.

In other regions of the Eastern Udmurt, an analogous phenomenon may be noticed. For example, in the Kuyeda district of the Perm Krai, the local activists tailored white-and-yellow caftans with decorated hems for their priests. One of the most active priests, the initiator of the general ceremony of all the Eastern Udmurt, the elen vös', Anatoli Galikhanov, who lives in Altaevo (district of Buraevo, Bashkortostan), ordered a white smock with red stylised applications.

In other Udmurt villages, as, for example, in Asavka (Baltachevo district, Bashkortostan), as the shortderem ceased to be used, the priests used to pray in ordinary jackets, ${ }^{27}$ but in the ceremonies they used belt towels, which granted them a sacral status. We have witnessed the same choice of jackets in the Udmurt village of Varkled-Bodya in Tatarstan, but there they had proper belts.

As far as the rest of the costume is concerned, i.e., the belt and the headgear, in Bashkortostan they all use towels instead of belts, except in case the sacrificial priest has been able to afford in Udmurtia a handwoven traditional belt, which he then uses - this is the case of the young Bal'zyuga vös'as' Fridman, to whom we offered one woven by a friend in Udmurtia. The priests, who are 
supposed to have their heads covered like all the other participants, used to have on their head a headgear swaddled in a white towel; with the exception of Vyazovka's priest, they all wear on their head ordinary factory-made headgear usually in light fabrics, and the whole image seems a bit casual. But it is of the utmost importance that their heads should be covered.

\section{Prayer texts}

During the ceremony, there are several moments in which the sacrificial priest recites prayers. Actually, except for the first prayer, the text is always the same, and each priest has one single prayer he operates with. ${ }^{28}$ We have not yet come to analyse in depth the texts of the prayers, in order to appreciate to what extent they have been adapted to modernity. Nor do we have a full overview of the changes made in the texts in the Soviet period. We can still mention two conversations: one with Evgeniy Adullin in June 2015, in which he reflected on the need to change the text in order to add wishes that would correspond to the actual situation in the twenty-first century. He doubted whether he was allowed to do that, and the next years will show what his final decision is. The other conversation was with Vladimir, the Asavka younger sacrificial priest, who wished to add to the traditional text words of thanks; his wish was accepted by the older priests and he added these words.

Here we would like to concentrate on considerable changes in the ways ritual texts, called kuris'kon (Udm. куриськон), have been transmitted from one priest to another in the course of time. Traditionally the rule was that prayers were not taught, they were supposed to be "stolen" from the older priests, and that means that they were learnt in situ, while the text was enunciated. This is the reason why the priests took with them children and teenagers as helpers, who thus absorbed their experience and learnt the texts of the prayers by heart. This was the method of transmission of the sacred text. If learnt in another way, the prayer was supposed to lose its magic strength (Sadikov 2011: 112).

Nowadays, there are only a few priests that have "received" their prayer in the traditional way. In the Vil'gurt group, we may mention Nazip Sadriev in Bal'zyuga and Rais Rafikov in Vil'gurt.

Some other priests have written down the texts of older priest's prayers and utter them either by heart or, in most cases, they read them from paper. Today this form of enunciation of a ritual text is accepted as natural, and the priests have also found ways of supporting the paper in front of them with a music stand or a reading desk. Although actually they have by now learned the text by heart, many still keep the text for safety reasons (e.g. Fridman, the young Bal'zyuga sacrificial priest); others, as the three vös'as' in Starokalmiyarovo, 
argue that it guarantees that they will say the text all together so that it will sound nicely. Usually, they use the texts of their predecessors in the village. Only in cases it has not been possible to retain the local prayer, they use "alien" texts, i.e., texts published in newspapers or written down by priests in other villages. This is the case, for example, with the old Bal'zyuga vös'as' Nazip Sadriev's prayer, which is used by several priests in other villages. For this particular purpose he kept a recorded tape of his way of saying his prayer. ${ }^{29}$ Clearly there is a transition from oral tradition to written one.

\section{Ritual actions}

A certain transformation has also taken place in the ritual part of the ceremonies. Several rituals have been simplified. Some of the simplifications may originate in adaptations from the Soviet period, some of them in the ongoing process. We will take as a starting point the Alga group rituals, which are the most complex ones we have met as yet. Still we must also take into account that there may have been some local peculiarities which are not explained by adaptation or change.

The first simplification we have noticed is the treatment of the first prayer, called siz'is'kon ('promise'): its goal is to promise Inmar a blood sacrifice. In some places, as in Kachak (Kaltasy district), this prayer has become a bloodless ceremony in itself, performed on two days between the main sacrificial ceremonies. ${ }^{30}$ In the Alga group (with the exception of the village ceremonies), the prayer siz'is'kon is performed on the previous evening: the priests prepare porridge without meat and allow the sacrifice. The fire must be kept burning all the night, until the beginning of the main part of the ceremony. The right bank Udmurt decided, before the others, to stop performing the siz'is'kon on the previous evening, because this meant they had to look after the fire the whole night, to prevent it from going out. So now, the ritual takes place in a simplified form, and the siz'is'kon is prayed right before the sacrifice. This is how it is done at the mör vös' as well as at the gurt(en) vös'. ${ }^{31}$ These are the places where continuity is preserved. In other places we have not attended enough village ceremonies, but in Aribash and Vukogurt, the ceremonies start without any kind of previous prayer or promise. We may assert then that this is a new simplification brought about by the process of revival.

A general change in the sacrificial process is that domestic birds are no longer sacrificed. Nazip Sadriev mentioned this change as the one he had brought forth himself. Geese were expensive and did not yield much meat. Clearly, at some undetermined time in the Soviet period, the sacrifice concentrated on ewes. We would not mention this change if there had been no attempts to revert to the 
more traditional way. In the Vil'gurt tol mör vös' in December 2016, the ritual started with the slaughtering of a goose - in a yard not far from the sacred location, while the bird, because of the difficulty to pluck it in twenty degrees below zero, was plucked in the nearby sauna. This is another of the innovations - or reverting to older traditions - that Rais is implementing in Vil'gurt. But this might require a strong motivation to take root especially in spring: practices concerning geese have been changing in the Udmurt areas of Bashkortostan and people do not keep geese all year round anymore: they take chicks from incubator in spring and slaughter them at the end of the autumn.

Most of the changes are connected to the way of dealing with the sacrificial meat and tend to simplify the team's task.

- After the ewe is slaughtered, it is butchered and non-used parts of it are burnt. In order to ease their work, the helpers usually discard the entrails of the animals, because their cleaning and washing takes much time. This happens most of the time. In the Alga group, we have usually seen it, except in the Nizhnebaltachevo village ceremony, where some women (probably Farkhulla's wife) dealt with the entrails and brought them back cleaned and washed; we saw it also in the Bal'zyuga village ceremony, where one of the helpers, Sidor, refused to discard the entrails and did all the cleaning himself. Also in Vil'gurt mör vös' the entrails were kept, because there were women there whose task it was to clean them. Cleaning the entrails is clearly a women's task. Unlike the Alga group, the Vil'gurt group involves women as helpers for this task; this explains the use of the entrails.

- Nowadays, in the butchering of the animal, the meat as well as the bones are chopped with an axe, while formerly it was important to keep the victim's bones intact and the meat was carefully cut at the joints.

- Not only sacrificial meat is cooked in the cauldrons, but also additional meat bought from the local shop in order to get the necessary quantities, although it has not passed through any ritual. This innovation was started by Nazip Sadriev.

- While formerly in all villages sacrificial meat was served separately from the porridge, now it is cut into smaller pieces and mixed with the porridge, both being served together. Local observers comment that this tradition was initiated by Nazip Sadriev, due to the reproaches from the members of the community, who complained they had got too little meat and who noticed that certain members of the community took considerably bigger amounts of meat then the others. 
There are also some differences in the Alga and Vil'gurt group rituals. One of them is the way participants present offerings. In the Vil'gurt group there are poles to which they tie the towels or other textile offerings. In the Alga group, all offerings are received by a sacrificial priest, who says a prayer on each of them, usually asking the gift-bearer for what he or she wishes him to ask God. The offerings are very abundant here, while in Vil'gurt there are fewer than a dozen tokens. This difference may or may not be connected with the revitalisation process, but we have no evidence to rely on.

Until now we have emphasised those of the changes that have led to the simplification of the rituals, in a context where the main goal was to revive the ceremonies. Still, in some cases, the attempt to revitalise has led to the revival of very old traditions, which may have been lost elsewhere. We stumbled upon one of these cases in Aribash, where, while reviving the ceremony, Aleksey inserted a feature from his reminiscences: in 2015, in Aribash, we were able to record how, when the ritual porridge was ready, youngsters invited the village people to attend the ceremony. In 2015, two teenagers walked in the central street of the village shouting: "Vös'e mynele, vös'e!” (Udm. Вӧсе мицнэлэ, вӧсе!; 'Go to the ceremony! To the ceremony!'). At the end of the nineteenth century, Finnish linguist Yrjö Wichmann observed that the village people were called by horsemen in white, who shouted: "Vös'e mynele ini!” (Udm. Вӧсе мынғлэ uнu!; 'Go to the ceremony now!') (Sadikov \& Hafeez 2015: 147). In Aribash, the tradition was restored; an informer from Aribash remembered the same tradition from her childhood. It may have existed elsewhere as well, but we have no information about it.

\section{RECENT DEVELOPMENTS: THE PARTICIPANTS}

We must emphasise that participation in a ceremony does not mean presence throughout the whole process. Usually, most of the time, only the sacrificial priest(s) and the helpers are on the spot - and sometimes the researchers. Village people come only when the porridge is ready, in order to share the meal and also take it home. In a wider sense participation starts earlier and finishes later: each household in the village gives crops, butter, and money to ensure the buying of the ewe and the porridge ingredients, and they receive the blessed sacrificial porridge as a final output. The eating of the porridge is a ritual act, and it may be accomplished later on at home.

The information we have about the Soviet time emphasises that the participants were small in number and limited to the aged. But this is not enough to estimate the real level of what could be transmitted inside the families, which 
might be higher than we imagine. In the Soviet times, young people obviously did not attend the ceremonies. Anyway, the ceremonies are held on Fridays, i.e., on a working day, which may explain the presence of mostly retired people. Still, only few younger men are able to attend, as many work far from their village. Some informants tell us that it was forbidden for younger people to attend. ${ }^{32}$ This may have been - or not - one of the forms of adaptation to the new conditions. What is confirmed by all the sources and informers is that small children were not allowed to participate, for they were considered as not able to keep ritual cleanliness; nowadays people of all ages attend also with small children, and young people of all ages partake and usually seem to be well familiar with the rules: heads must be covered as well as legs/feet and arms. Vös'as' and vös' kuz'o keep repeating the rules and check that everyone respects them. In Nizhnebaltachevo we saw how adults threatened children, who wore shorts and whose arms were not covered, with the reactions of Farkhulla who later sent them back to get proper clothes.

Rules are not so strict any more concerning the colours people are supposed to wear: informers say that people wore white shirts (vös' derem, вӧсь дэрем) and white caftans (shortderem) or at least they were dressed in light tones. The ordinary participants in the ceremony come in their Sunday best; women wear coloured bright dresses, and some of them come dressed in Udmurt fashion. Only the elderly, respecting tradition, try to wear light colours.

Another important rule has been changed in the last decades: formerly, only those were allowed to attend who had the right to do it: in the village ceremonies, the population of the given village participated, in others, the inhabitants of the respective villages, while at the festive events organised after the ceremonies, all the kin gathered from different villages. The presence of outside observers was not desirable. ${ }^{33}$ The question of outsiders was probably not topical during the Soviet times, when secrecy was recommended. But this has changed in the last two decades. On the one hand, a ceremony is an event. People from different villages, if they happen to be at a place where there is a ceremony, attend along with their kin. In the cases of the mör vös', the two ceremonies of the Tatyshly district are even scheduled in different weeks, so that the kin may visit on these days. This may suggest a new understanding of the community. Moreover, now outsiders often attend the ceremonies: scholars, journalists, cameramen, etc. ${ }^{34}$ And so do we. Until now, we have been well accepted. No calamity has followed our presence, and people have got accustomed to it. Still, we cannot rule out the possibility that at some point the sacrificial priests would wish to have their ceremonies outside the field of observation, thus re-establishing the former rules. 


\section{CONCLUSION}

In this overview of the processes of tradition revival undergone by the Eastern Udmurt, we tried to understand what was going on, and what was the starting point from which they began at the end of the 1980s. In some cases, a near complete ritual continuity was guaranteed throughout the Soviet period, when there were strong personalities able to resist all the anti-religious pressures: a near complete continuity does not mean that nothing changed, but that the ceremonies were not discontinued, with due evolutions and adaptations. In other places, the ceremonies have indeed been interrupted. But the revival has taken place everywhere: in the places where ceremonies have always been held, they are more widely attended, and where they are newly re-established, we can see that they respond to the people's expectations.

We have the impression that the age of the settlements has no great impact on the way religious practice has been retained over the years. History, nevertheless, still exerts an impact on the way ceremonies are organised: the Alga group village ceremonies involve villages that are historically connected, the inhabitants of one village having often migrated from the other.

During the revival process, changes in tradition have occurred. If we analyse those processes at the most elementary level, we notice that usually they have led to the simplification of the rules, following a trend that had already been developed in the Soviet times, when sacrificial priests concentrated on what they considered as essential. The more recent the revival, the more simplified the ritual, as we have seen in Vukogurt. If we look at them from a wider perspective, some interesting trends have emerged, which we attempt to pinpoint below.

- We have noticed that there are very concrete and very diverse persons behind the revitalisation of religious practice. All of them have acted out of conviction, either religious or political, and probably a mix of both. We would like to emphasise the role of former political leaders who have set their authority on behalf of religious revival. They were former Soviet leaders, ${ }^{35}$ who fully used their local political networks and their influence to get the revival enacted. In some way it shows the vitality and efficiency of the former kolkhoz structure and system. Actually the whole life was structured by these cooperative enterprises: there were several kolkhozes in the Tatyshly district, one covering only Udmurt villages (called Demen), and others in which the Udmurt villages constituted only one part. They were the main employers of the population. While the kolkhozes as such have disappeared, and have been replaced by cooperative enterprises, the names of which have not changed and which are still called kolkhozes by the population, the network they represented still functions as an empowering tool. This is an unexpected discovery. 
- At the level of the religious system as a whole, on the one hand, we do not see any tendencies towards actual institutionalisation and centralisation: no attempt has been made to create "a church", a hierarchy, or even, as we have seen, a centralised organisation. For instance, it has been done in the Mari Republic, where the Mari ethnic religion is officialised at the same level as Russian Orthodoxy (Alybina 2014). There was an attempt to coordinate the sacrificial priests' action by establishing an association of the vös'as', but until now it has not been achieved.

- On the other hand, several signs show that there is a trend toward some kind of mild fixation of the rules. Several signs do suggest it. One of them is the general fencing, whose function is to separate and distinguish particular areas, to give them a clear meaning. This is particularly interesting in the late evolutions - in the already fenced sacred places (fenced externally) new fences start to be built inside, in order to mark different statuses. Another very interesting development concerns the medium of the prayers. The introduction of written culture is contradictory to the oral transmission of tradition. All world religions have their Holy Writ. The priest in Vukogurt commented to us that as other religions have written texts, why not the Udmurt one, but this sounded as a justification for the paper he was holding in front of his eyes. The Udmurt religion is not moving towards this kind of text, yet texts are being fixated in written form, which may well represent a way of restrained improvisation.

- We want to discuss Anna-Leena Siikala's conclusion that by turning religious ceremonies into festivals, the Udmurt have found a way to give them relevance in their identity endeavours (Siikala \& Ulyashev 2011: 310). We will not comment on the experiences she has analysed in Udmurtia (although they would deserve discussing and updating, for these processes are ongoing), but as far as the Eastern Udmurt are concerned, the festival dimension exists in only one case, which has not been discussed within this article: it is literally "the country" sacrificial ceremony elen vös' (see Sadikov 2010), which was recreated in 2008, and which indeed attracted huge media interest. The other village or village group based ceremonies are performed for the internal needs of the communities and, while they may have ethnic consolidation effects, they are not seen by the people concerned as responding to wider interests rather than the welfare of the village itself.

Finally, we must reflect on our own influence on the ongoing processes. In the last years, the Eastern Udmurt, especially the Tatyshly Udmurt, have become used to seeing researchers at their ceremonies - we have, for example, 
attended the Vil'gurt mör vös' two years in a row and many have shown that they expect us to be there every year. We must be aware that our presence has its own consequences from the point of view of these same processes. We have tried to take it into account in our own practice: for example, we are aware of the formidable tool that video represents. Not only by filming ceremonies, but by leaving the roughly edited material, we may be instruments in the future of several possible scenarios, some we are happy about, some of them dangerous. While we are quite happy if our material helps transmission, and especially oral transmission, we will keenly follow the eventuality of possible standardisation. Therefore, we have planned to attend all the village ceremonies, in order to record every single local experience and to avoid contributing to the impoverishment of tradition. This ethical choice imposes on us a long research programme, for all villages hold their village ceremony on the same day and there are nineteen of them.

Hereafter we propose an account of the possible consequences our action may induce, not only on the bases of our reflexions but also of reactions we have been informed of.

- We already mentioned the unintentional influence our presence had on the Asavka priests, who tried to act according to former tradition, which has long been forgotten in their village. This shows a well-meaning willingness to act according to the old rules of the Udmurt, although it misinterprets our meaning, for we intend to show respect to all forms of practice that have been implemented in different locations. But their approach was different. It reveals a particular understanding of what is right and what is wrong, and emphasises the importance for the people to feel that what they do is rooted in deep historical values, followed by the Udmurt as a whole.

- There are interesting expressions of envy connected with our presence, both outside and inside the Udmurt community. Outside the Udmurt community, our regular presence has kindled envy from the leadership of the district, which is composed of Tatar leaders. Several times the district head Rushan Garaev has expressed irritation that foreign researchers are interested in the Udmurt and not in the Tatar. On the other hand, there is a kind of competition between the villages whose ceremonies we have not attended yet. "Why have they gone there and not visited us? We also have ceremonies," is a sentence that can be heard quite often, and we are always in trouble to decide where we want to film the next ceremonies.

- The other side of the coin is that our presence has been stimulating for both the sacrificial priests and the population. This interest from 
outside and the respect the regional culture elicits in the researchers has clearly enhanced their interest in their own cultural values; the sacrificial priests, until now at least, seem happy to be filmed and never put any obstacles to our activity. They welcome us and they are even inclined to ask our opinion on questions that concern them. This was the case when Evgeniy Adullin, reflecting on the inadequacy of the prayer texts for the present challenges, contemplated the possible changes and asked for Eva's advice on this issue.

- This same approach was quite explicit in an experience that part of our team, Eva and Nikolai, had when invited at a round table organised by the historical-cultural centre, which thus gave us the opportunity to explain what we do in our fieldwork and what the perspectives of our investigation are. Some sacrificial priests and some local leaders had been invited, as well as the leader of the national movement, who encouraged us to make proposals and to express our ideas about the contents of the local journal or the problems of the fencing. On the basis of our own experience, we encouraged them to publish information about the religious life of the region, to have a regular column about religion; this advice was followed for two or three months only to be forgotten later on.

- Our influence may also be indirect. When the historical-cultural centre organised an event associating grandmothers and granddaughters in order to focus on culture transmission practices, they deliberately included in the programme a part on religion, because we were attending a ceremony in the same village on the same day. By doing so, they ensured that the grandmothers publicly spoke to their granddaughters about religious practice.

- Another wider impact of our interest concerns the relations between the Udmurt media in Udmurtia and the Eastern Udmurt culture: clearly we do not have a neutral position in this matter. As an Udmurt, one of us, Nikolai, is particularly keen on awakening interest in his research in his country. And he is not the only one. In 2015, Eva concluded an agreement with the Udmurt television: it was about sending a cameraman to the Aribash ceremony, for our own film specialist, Liivo Niglas, could not attend. The ceremony was filmed. But the result of this process is more extensive, because the Udmurt television discovered the richness of the Eastern Udmurt culture. They made a documentary with the material the cameraman brought back, but from this moment on several films have been shot on Eastern Udmurt ceremonies and we have met Udmurt television groups filming at least twice in autumn and winter ceremonies. 
- Thus, we are aware that our presence elicits reactions that may influence the process itself in the long run. We attempt to consider it in order to avoid undesirable influences, but must accept that our interest, on reflection, also stimulates interest in others.

What is important here is that the revitalisation is clearly an answer to the population's expectations: more and more ceremonies are being recreated, and the process is not closed.

\section{ACKNOWLEDGEMENTS}

The whole article is based on research supported by the Estonian Research Council, grant PUT 590, Contemporary Finno-Ugric Animism: Functions and Social Context (2015-2018), the Finno-Ugric Ethnic and Religious Discourses project of the University of Tartu, and the Estonian Kindred Peoples Programme project No. 782, Finno-Ugric Religious Manifestations of Identity.

\section{NOTES}

1 Published in Folklore: Electronic Journal of Folklore, Vol. 72.

${ }^{2}$ Ceremony in which all the villages of each group gather, 10 in Vil'gurt, 9 in Alga.

3 Fieldwork materials of Ranus Sadikov from 2000, Vukogurt, Tatyshly district; Yamiga Sharapova, born in 1934.

4 They had distinct functions: the vös'as' was responsible for the prayers and for the whole ritual process, the tylas' looked after the sacrificial fire and threw into it bits of the sacrificial food for the gods, and the partchas' were the ones who slaughtered and butchered the sacrificial animals.

5 We should stress here that participation in the ceremony is not only expressed through personal attendance. People from these villages offer money to buy the sacrificial animal, and they gather crops for the ritual porridge. At the end of the ceremony, the sacrificial priests bring back the porridge with the meat in big cauldrons to each village and they distribute it to the villagers. In the majority of cases, only the sacrificial priests and their assistants - as well as the anthropologists - participate directly in the ceremony itself.

${ }^{6}$ For this achievement, he was bestowed the "World Tree Award" in 2016, an Estonian award given to people who, at grassroots level, were able to help maintain Finno-Ugric cultures.

7 He did not, however, visit only the Tatyshly Udmurt, but he was also invited to revitalise ceremonies in other districts of Bashkortostan as well as in Izhevsk, the capital of Udmurtia. 
8 Older informants have observed that when he was a local leader in the Soviet period, Rafik Kamidullin was one of the most active party officials to fight against any manifestations of religious practice.

9 In Russian: Национально-культурный центр удмуртов Башкортостана.

${ }^{10}$ Fieldwork of Ranus Sadikov and Eva Toulouze in Tatyshly district of the Bashkortostan Republic in 2015; Garifulla Garifanov, born in 1947 (Nizhnebaltachevo).

${ }^{11}$ This is one of the Soviet positions in the kolkhozes: operator of agricultural machinery.

${ }^{12}$ Fieldwork interview in June 2016.

${ }^{13}$ As Vil'gurt is a big village, according to tradition there have always been two sacrificial priests.

${ }^{14}$ The traditional Udmurt society was divided into clans - kinship groups having the same mythical ancestor. The system is not relevant anymore, but some remembrance of it remains alive, as in this case.

${ }^{15}$ Although this might be more directly connected with Aleksey's shyness: he acknowledged to us that he still has butterflies when he prays.

${ }^{16}$ A report about the ceremony in Vukogurt can be found at http://blog.erm.ee/?p=8708, last accessed on 21 September 2018.

${ }^{17}$ Fieldwork interview in June 2015.

${ }^{18}$ A detailed report about the ceremony in Nizhnebaltachevo can be found at http://blog. erm.ee/?p=8783, last accessed on 21 September 2018.

${ }^{19}$ In June 2013 at the mör vös' as well as at an occasional ceremony in Utar Elga; in December 2013 at the tol Bagysh vös' and at the tol mör vös', and finally in June 2015 at the Bagysh vös'.

${ }^{20}$ Except in private circumstances: he prays at home in the autumn ceremony (Udm. Сӥзььлл куриськон), at marriage ceremonies, etc.

${ }^{21}$ In Russian: Удмуртский историко-культурный центр.

${ }^{22}$ However, Liivo Niglas was allowed, without any question, to enter the fenced area in order to film the proceedings.

${ }^{23}$ In one case it was because the hut was inside and the weather was very cold and windy (in December 2013); in other cases, it was to eat the sizis'kon porridge.

${ }^{24}$ In December 2016, we attended an evening in Vil'gurt, dedicated to grandmothers and their granddaughters. One of the grandmothers took from her chest a shortderem and put a white scarf on her head, saying: "That's how I pray".

${ }^{25}$ At the same event, the grandmothers were asked to comment on the content of their chest and we were surprised to discover that several of them contained old shortderems.

${ }^{26}$ White is the colour of the highest god, Inmar, to whom the prayers are addressed. 
${ }^{27}$ Actually in Asavka we witnessed our influence, which was mostly unlooked for: in June 2016, we met the sacrificial priests one day before the ceremony, and Ranus Sadikov mentioned in a conversation the tradition of the shortderem. While their local tradition has been to pray in jackets, the following day all the three vös'as' were dressed in white, one in an old shortderem (actually he did not find any man's shortderem and he wore a woman's), the two others in ordinary smocks. In December 2016, at the tol vös', one of the priests wore a jacket, while the other insisted on wearing a white smock.

${ }^{28}$ Many prayers have been published, many more have been collected and are in archives, usually not transcribed, and we have already recorded several prayers in our materials. We (Ranus Sadikov and Eva Toulouze) are preparing a collection of prayers of the Eastern Udmurt.

${ }^{29}$ But this seems to have been lost.

${ }^{30}$ Fieldwork in June 2018.

${ }^{31}$ A report of Bal'zyuga village ceremony can be found at http://blog.erm.ee/?p=8542, last accessed on 21 September 2018.

${ }^{32}$ Fieldwork interview in Asavka, December 2016.

${ }^{33}$ This is very eloquently illustrated by Uno Holmberg [Harva], a Finnish scholar of religion, when in 1911, at the time of his expedition, the population of a village explained a natural cataclysm (snow after sowing) during his visit to sacred places (Sadikov \& Hafeez 2010: 79). This experience has been widely shared by researchers; for example, Aado Lintrop in Varkled-Bodya (Lintrop 2003: 213).

${ }^{34}$ During our field research in 2016, our driver reported the words of one of the priests about the attendance of scholars in sacrificial ceremonies: clearly from the ritual point of view their presence was not desirable, but ethically it was not possible to prevent them. However, nobody has said that to the scholars themselves. This does not mean that this kind of discussions would not take place in more intimate settings among the organisers of the rituals.

${ }^{35}$ Galyamshin had a huge portrait of Lenin in his office when Eva first met him in 2011.

\section{REFERENCES}

Alybina, Tatiana 2014. Vernacular Beliefs and Official Traditional Religion: The Position and Meaning of the Mari Worldview in the Current Context. Approaching Religion, Vol. 4, No. 1, pp. 89-100. http://dx.doi.org/10.30664/ar.67541.

Kamidullin, Rafik 1994. Oskon: inkuaz'ly iybyrttysa, vös'mes vyl'dysa. [Faith: Worshipping Nature, Reviving Religion.] Az'lan' (Verkhnie Tatyshly), No. 51.

Lintrop, Aado 2003. Udmurdi usund. [Udmurt Religion.] Tartu: Eesti Rahva Muuseum. Sadikov, Ranus 2008. Traditsionnye religioznye verovaniia i obriadnost' zakamskikh udmurtov (istoriia $i$ sovremennye tendentsii razvitiia). [The Traditional Religion of the Trans-Kama Udmurts: History and Modern Tendencies.] Ufa: TsEI UNTs RAN. 
Sadikov, Ranus 2010. Elen vös' - moleniye stranoy: Zhivaya drevnost' na prostorakh Bashkirii. [Elen vös' - the Ceremony of the Country: Living Antiquity in the Horizon of Bashkiria.] Vodrskem kyl, No. 7, pp. 34-35.

Sadikov, Ranus 2011. Molitvy-kuris'kon zakamskikh udmurtov (modernizatsiia kul'tury - transformatsiia teksta). [The Prayers-Kuris'kon of the Eastern Udmurt (Modernisation of Culture - Transformation of Text.] In: R. Sadikov (chief ed.) Traditsionnaia kul'tura narodov Uralo-Povolzh'ia $v$ usloviiakh modernizatsii obshchestva. Sbornik statei. Ufa: IEI UNTs RAN, pp. 109-133.

Sadikov \& Hafeez 2010 = Sadikov, Ranus \& Khafiz, Kirsi. Religioznye verovaniia i obriady udmurtov Permskoi $i$ Ufimskoi gubernii $v$ nachale XX veka (ekspeditsionnye materialy Uno Khol'mberga). [Religious Beliefs and Rites of Udmurts in Ufa and Perm Provinces at the Beginning of the 20th Century (Uno Holmberg's Fieldwork Materials).] Ufa: IEI UNTs RAN.

Sadikov \& Hafeez 2015 = Sadikov, Ranus \& Khafiz, Kirsi. Finskii issledovatel' Iur'e Vikhmann o religioznykh verovaniiakh udmurtov Ufimskoi gubernii (konets XIX v.) [The Finnish Researcher Yrjö Wichmann about the Religious Beliefs of the Udmurt of the Ufa County (End of the 19th Century).] In: A. Psianchin (chief ed.) Ot plemeni $k$ etnosu (etnografiia $v$ russkom geograficheskom obshchestve. Sbornik statei. Vyp. 2. St. Petersburg: Svoe izdatel'stvo, pp. 135-159.

Sadikov, Ranus \& Mäkelä, Kirsi 2009. Yrjö Wichmannin muistiinpanot Kaman-takaisten udmurttien uskonnollisista käsityksistä ja tavoista. [Yrjö Wichmann's Memoirs about the Religious Understandings and the Habits of the Eastern Udmurt.] Suomalais-Ugrilaisen Seuran Aikakauskirja / Journal de la Societe FinnoOugrienne, No. 92, pp. 241-263. Available at https://www.sgr.fi/susa/92/contents. htm, last accessed on 20 September 2018.

Siikala, Anna-Leena \& Ulyashev, Oleg 2011. Hidden Rituals and Public Performances. Traditions and Belonging among the Post-Soviet Khanty, Komi and Udmurts. Studia Fennica, Folkloristica 19. Helsinki: Finnish Literature Society.

Toulouze, Eva 2016. Some Ideas about Continuity and Revitalization in the Udmurt Spring Rituals in Bashkortostan. In: E. Iagafova (chief ed.) Prazdniki i obriady $v$ Uralo-Povolzh'e: traditsii $i$ novatsii $v$ sovremennoi kul'ture. Sbornik statei. Samara: SGSPU, pp. 17-20.

Toulouze, Eva \& Vallikivi, Laur 2015. Les langues dans un miroir déformant. Études finno-ougriennes, No. 47 [online]. DOI: 10.4000/efo.4906.

Toulouze, Eva \& Vallikivi, Laur 2016. The Sacred Places of the Bashkortostan Udmurt. Ezhegodnik finno-ugorskikh issledovanii, Vol. 10, No. 3, pp. 146-155. Available at http://finno-ugry.ru/files/1303172918.pdf, last accessed on 20 September 2018.

Toulouze, Eva \& Vallikivi, Laur \& Niglas, Liivo \& Anisimov, Nikolai 2017. Udmurdi ohvripapp Nazip Sadrijev. [Udmurt Sacrificial Priest Nazip Sadriev.] Soome-ugri sõlmed 2016. Tallinn: MTÜ Fenno-Ugria Asutus, pp. 119-125.

Toulouze, Eva \& Niglas, Liivo 2017. La cérémonie appelée 'keremet' (ou 'lud') chez les Oudmourtes du Bachkortostan. Études finno-ougriennes, No. 48 [online]. DOI: 10.4000/efo.6730. 


\title{
MULTI-DIMENSIONAL BORDERS IN NARRATION
}

\author{
Tiiu Jaago \\ Associate Professor of Estonian Folklore \\ Institute of Cultural Research, University of Tartu, Estonia \\ e-mail:tiiu.jaago@ut.ee
}

\begin{abstract}
The article analyses the story of two Estonian soldiers (so-called Finnish Boys, a volunteer Estonian unit in the Finnish army), who escaped the Finnish army during the Continuation War. The reason for their desertion was the fact that the Estonians who were serving in the Finnish army were to be sent back to Estonia, where they would have had to serve in the Nazi German Army. They crossed the Finnish-Swedish border at Tornio/Haaparanta in the autumn of 1944. The story was recorded by the narrators themselves in Sweden in 1975 . In the article, this story of the escape and state border crossing is dealt with from the aspect of experience and narration. Questions arise concerning how the territorial border is marked in the narrative, where the symbolic borders are revealed, and how the narrators interpret the moral aspects related to the border and its crossing.
\end{abstract}

Keywords: border, Continuation War, experience, Finnish Boys, life story, narrative

This article focuses on a narrative about borders. The observed story was narrated by two men who recalled their war experience, including their escape from Finland to Sweden in the turmoil of World War II. The article asks how the narrators visualise the state border, how they position themselves in relation to the events before and after the state border crossing, and how the change in their roles influences the style of the narrative, as well as what kind of more general (political, autobiographical, etc.) contexts they keep in mind while interpreting their escape. Although the narrated escape story focuses on the details of the state border and crossing thereof, it covers territorial, political, cultural, narrative, and autobiographical aspects. The analysis is based on the folkloristic research of real life narratives (see Apo 1995; Allison 1997; Palmenfelt 2006): which events of their lives people talk about, in which circumstances they do it, and what factors affect the narrative. Therefore, the focus is laid, on the one hand, on the real-life experience (from the point of view of both the experience 
and the social-cultural environment of the narrators or their audience), and, on the other hand, on narrating as a cultural practice. The first half of the article includes biographical, historical, and theoretical references that provide a background to the text analysis presented in the second half of the article.

\section{EVENTS AND MEMORY: HISTORICAL AND BIOGRAPHICAL BACKGROUND}

The analysed story is a conversation between two men, in which they recall events that took place in Northern Finland in the late summer of 1944. At that time, they were fighting in the Continuation War as Estonian volunteers in the Finnish Army Infantry Regiment 200. There were slightly more than 3,300 such volunteers. Most of them, like these men, escaped from Estonia to Finland in 1943, when recruitment to the German Army started in Estonia. In August 1944 the volunteers were sent back to Estonia, where they still had to join the German Army, from which they had fled to Finland one year before (see Noormets 2011: 41-44). The protagonists of the observed story decided not to return to Estonia in August 1944, but to escape to Sweden. In Sweden their paths parted, until they met at the turn of 1974 in Stockholm to remember the days spent as volunteers in Finland. One of the men recorded this conversation for the purposes of his family archive. The recorder's wife handed over this tape to the Estonian Life Histories Association in 2008. It appeared that this recording no longer had a meaning for the family archive, as their descendants living in Sweden did not understand Estonian. Furthermore, this recorded story had exceeded the family's sphere of interest after the Cold War and the restoration of independence in Estonia. This issue had become one of the parts of the public discussion in the new historical frame. This article is based on the above-mentioned recording. At this time the digital copy of this recording is retained in Tartu, in the Estonian Life Histories collection of the Estonian Literary Museum (EKLA 350: 2525). The length of the recording is 1 hour and 15 minutes. During this time the men recall the explosion that took place in the Jalkala training camp in Finland, then they reminisce how they fled to Sweden, and finally they evaluate their choices and the fate of their war companions in a broader historical-political context. In addition, the background of this recording is reflected in an interview with the wife of the recorder of the memories in Stockholm in 2008 (MK: Stockholm 2008, E. T.).

Regarding the lives of these men, it is known that the recorder of this story was born in Tallinn in 1925. In the summer of 1943, he had just completed studies at Gustav Adolf Gymnasium in Tallinn. In February 1943, a call for 
mobilisation had been announced in the recently-occupied Estonia for men born between 1919-1924. Many conscripts found the opportunity to flee to Finland to escape recruitment by the German occupation troops (Leemets 1997; cf. Varblane 2011: 165-167; Jaago 2011: 326-329). Although he was not yet included in the draft (the respective order for those born in 1925 was issued in October 1943), he went to Finland in place of his friend. His friend had managed to procure a place in a refugee boat for himself, but at the last minute nonetheless decided to stay in Estonia, because he had a wife and a child in Estonia. The mother and father of the protagonist of this story, on the other hand, had recently died and he had been left alone in Tallinn. In 2008 his wife talked about it as a very quick decision: one summer day his friend had made this proposal and already the same evening he was on board as a refugee going to Finland. In the early autumn of 1943 he was enrolled in the Finnish army (see Leemets 1997). After the war he went to Germany to study (according to his wife he could not study in Sweden because the Swedish government did not accept the Estonian gymnasium certificate), and then worked as an architect in Sweden. He died in Stockholm in 1990. His partner on the escape journey in 1944, as well as in the conversation recalling that event, was much older than him, born in Russia in 1912. Before the war he had worked in western Estonia as a car mechanic. Soon after escaping from the Finnish army to Sweden he also found a job, as he had good qualifications (see also Leemets 1997; MK: Stockholm 2008, E. T.). It appears from the narrator's wife's explanations (and it can also be deduced from the men's reminiscences) that it was this older man whose initiative it was to escape to Sweden: he could not return to Estonia because he had an unresolved conflict with the German occupation authorities. During the events of 1944, one of the men was 19, the other 32 years old. When they met again in Sweden in the 1970s, they were 49 and 62 years old, respectively.

The biographies of the men show that crossing of the Finnish-Swedish border, which is the focus of this article, was not, by a long stretch, the only border crossing in their lives. Although all the crossings were interrelated, it was namely this particular one that had the greatest impact on the men's lives. So, the storytellers reminisced about the event that crucially changed their lives - their escape to Sweden. They also shared a military background: this is especially emphasised in their discussion about the aftereffects of the war. However, after that crucial event they did not meet again, as is revealed in their life stories. One might ask what made them look for one another's company after thirty years. Two factors should be considered here. On the one hand, the in-between period primarily involved adaptation to life in a new country, but by this point they had achieved certain stability. The activation of autobiographical memory and the need to reminisce about past events is related 
to a psychological process that helps in adapting to a new stage in life (Bluck $\&$ Alea 2008: 56). The other aspect, however, is the general context of collective memory. Just prior to this (1973), the first overview of Estonian young men who had served in the Finnish Army had been published (Uustalu \& Moora 1973). In the analysed interview text, the phrase "but now, in hindsight, as you read this book" is likely to refer to that book. It should also be mentioned that the international celebrations of émigré Estonians (the so-called Esto Festivals) started in the 1970s, i.e., at the same time that the story discussed in this article was recorded. Perhaps the emergence of this topic in the collective Estonian consciousness inspired these men to observe their own individual experiences within the overall picture. A 2006 study by Tiina Kirss, who has researched Estonian refugee communities, revealed that "Estonians who had escaped to the West were aware of themselves collectively as companions-in-fate" (2006: 626) and one of the manifestations of such awareness was narrating stories about the escape. Referring to the context of the memory culture, Kirss asks what role was played by the narration of escape stories in this awareness of belonging, whether it was informal and among close associates only, or during the celebration of anniversaries and other important days, when people not only reminisced about how their escape took place, but also about why and from what they escaped (Kirss 2006: 626).

Understandably, also the memory analysed herein is a part of the process described by Kirss, but a specific feature of this particular case is that the men were not private civilians escaping, since at the moment of the escape they were deserters. Obviously, this was not a fact that they would have liked to emphasise immediately after the war, while adapting to life in a new country. This was probably also the reason why the passage of time was needed for recalling these end-of-war events.

\section{BORDERS, EXPERIENCE, AND NARRATIVE: THEORETICAL BACKGROUND}

The more general context for the analysis of this narrative is provided by interdisciplinary border studies, in which the border is dealt with as a multi-level and processual phenomenon (Paasi 1996: 15-16; Newman 2003: 13-14; Custred 2011). In this narrative, the border is first signified as the state border between Finland and Sweden. In the context of World War II, however, the border also had a symbolic meaning - on the one side there were the warring countries (including Finland, Nazi Germany, and the Soviet Union), and on the other side there was Sweden, which maintained neutrality during the war. The third 
level is the border associated with Estonia: on the one hand, it was the narrators' home, and on the other hand, an area controlled by occupation authorities.

From the viewpoint of real life narrative, one of the most important categories of the analysis of the observed story is experience (see Pickering 2008). On the one hand, experience is based on what a person has lived through. However, on the other hand, when talking about experience, one also has to consider how the social-cultural and historical-political backdrop affects the choices made in real life as well as how narrators interpret their choices. Therefore, we may ask about the border experience of the narrators, but we are also interested in how they present and interpret their experience. As experience is in the narrative form here, the mutual relationship of the situated and the mediated experience has to be taken into account in the analysis. The research of experience is based on the principle that the story provides access to a past event, but the narrative and the narrated event can be interpreted in a more general, communicative context (see Pickering 2008: 28). Real-life stories are always also cultural texts, in which both the conceptualising of what happened, other similar or related texts, and the imaginary auditorium have their role (Lawler 2008: 48). In this sense, experience is a continually-developing phenomenon: relying on a specific real-life event, experience at the same time also embraces the meanings and associations of the time the narration covers.

Through the narrative, as one possibility for expressing experience, this analysed story is also associated with border poetics research (see Schimanski $\&$ Wolf 2010). Border poetics research studies also reveal the processual and multi-level nature of the border: for example, the crossing of the state border as a certain obstruction (barrier) brings up the topic of symbolic borders, which are not exclusively related only to the decisions and actions of the one who crosses as an individual person. Schimanski (2006: 53) shows that border-crossing narratives can also be analysed "for their textual, topographic, symbolic, temporal and epistemological dimensions". On the textual level are the analysed topics, episodes, imagery, etc. The topographical level is associated with a certain spatial dimension, and the temporal level refers to both the biographical and the historical time scale. Symbolic borders are the subjective or perceived borders. The epistemological level distinguishes the known from the unknown. For example, as Schimanski (2006: 56) explains, "Epistemological borders are often placed between home territory and foreign places".

In the text analysis all these aspects (relations of experience and expression) are interconnected: the description of crossing the state border is related to the experience of the specific activity as well as describing the features of the real border. The latter includes both descriptions of the landscape and the protagonists' feelings and thoughts at that moment. It can also be noted in the text 
how the way of describing is completely different after the border crossing, be it caused by the change of the role of the protagonists in the new circumstances or the description of "another" landscape and culture.

\section{TEXT ANALYSIS}

The audio recording of the escape story was transcribed for analysis using folkloristic principles; i.e., the written text has not been revised or edited. The observed story is presented in the form of a dialogue between the two protagonists, and it consists of three thematic parts: preparation for the escape; the journey to the border; and resolving the situations in Sweden. In the introductory part - preparation for the escape - we learn about the search by one of the men for companions with whom to escape from the military unit to Sweden. With regard to looking for companions, they also remember the discussions about what the border that has to be crossed looks like in the men's imagination. When a companion is found, options for escape are sought: for example, the option of going by boat across the Gulf of Bothnia is considered, but neither of the men feel safe at sea, so this plan is discarded and they decide to go by land. Thereafter they talk about their discussions about how to arrange their escape (gathering and hiding the provisions, and about the question of how to get out of the unit so that no one would notice):

Older man: We had taken as much as we could during each meal; we took bread, took it into the forest, and hid it under a tree stump. And so it was on Sunday at around one. We had planned to go that day. [---] took those bread provisions from under the stump there, you know, and just vanished from there, so that nobody would notice.

Younger man: Yes, I also remember it like that, when we came away from the schoolhouse, I was wearing the uniform and went to the toilet. And there I met a Finnish man [---], who looked at me with surprise and said, well, are you going into the village or what. I was wearing the uniform, wasn't I, just walking round there. I told him yes, now, I am going into the village. It was, I believe, yes, around one o'clock or so, when we left.

The second part of the escape story contains the description of the journey. In this part, the ways of describing the geographical space, the experienced events and the duration of the journey (i.e., the timeframe of the event) are highlighted. The space of action can be easily reconstructed: they mention place names and describe landscapes. The important places during the journey are rivers, sentry posts and bridges, which were difficult to cross for one reason or another; forests, 
hay barns, edges of fields - these were important for hiding and having a rest. It appears that when reminiscing about the journey, important landmarks at geographical places are places that are related with experiences, for instance places that were associated with hardships experienced during the journey.

The time frame of events in the story is general - it is from the second half of August to the first half of September 1944. More precise time definitions (e.g. hours) are emphasised in the text when certain decisive moments are described: probably these were also precisely fixed in real life that the story is based on. For example, the moment of fleeing from the unit (it was on Sunday at about one o'clock), or the moment of arriving at the Tornio River:

Older man: That was in the morning, I remember ...

Younger man: Yes, I do remember that. We got there in the morning. The sun was rising. It may have been three or four or something... There was mist on the ground and the sun was rising, and it was light, completely light...

The end of the escape is also defined by a date: it was September 22, when they got a job in Sweden and then went their separate ways. Mostly the reader (or listener of the recording) can perceive the time through the descriptions of weather and the narrators' bodily experiences (e.g., they were extremely cold because 'it was August, and in August it is fairly cold there in the north, there was frost on the grass, tall hay on riverbanks...'). In addition, in these descriptions one can see the comparison of familiar and unknown environments (Schimanski's 'epistemological border'). It is not clear how many days the journey lasted: they count two days (e.g., 'that was on the evening of the second day'), but after that they just mention whether it was evening or morning (e.g., 'it was evening and we had walked quite a distance', 'and see, that was one evening again', or 'we arrived there in the morning. The sun was rising', etc.). According to the descriptions of the days and nights, the journey seems to have lasted not less than four days and nights.

The narrators themselves refer to the escape as a "hike" or a "journey", which in turn consists of single events that they call "adventures" (e.g., "the next adventure that we had was...').

Older man: And the first adventure we had, as I remember, was that we went to $I i^{1}$ or whatever it was, went through there to the riverside and there was a Finnish soldier in a boat just about to go across the water, across the Ii River [---]. He took us into the boat, so that we happily crossed that first river and gave two or three cigarettes for that to this soldier. 
Younger man: The first thing I remember... when we went there - there was Olhava station - and bridge [---] and a guard post on the bridge. [Older man: Yes]. And in my opinion, it was the next adventure, after we had come across [the river] at Ii. [Older man: Yes-yes!]

Why use just this word? On the one hand, it is one method of narrating - to talk about real life as an adventure (see Mertelsmann 2011). On the other hand, an 'adventure' sometimes means that they survived, while not to survive could have been 'fate'. For example, when they speak of men they knew who were killed in the war - the situations of their death and not just the fact that they perished - they sum up the topic as follows: 'this was the way his fate was determined'.

There are two types of such adventures or narrative events. One is related to meetings on the bridge, at the sentry posts, on the road. These meetings, mainly with Finnish or German soldiers, were associated with risk. They call hiding away from the roads in the forest to avoid such meetings, or also after the meetings, evaporating (e.g., when they came along a forest path to a glade, into a German camp, they confidently greeted the sentries, but then in retrospect recounted: 'Yeah there, when we had come through there, oh hell, we evaporated into the woods, as soon as we could'). Another type of adventure is associated with nature: e.g., when they avoided roads, 'our forest adventure started: wetlands and wooded bogs'. The most complicated ones, however, were rivers, and there were many in that region:

Younger man: Yes, there were a lot of rivers, as soon as we had crossed one, there was another again not too long afterwards.

Older man: Yes, there were those river bends. Just crossed one, another was ahead! No other way, you have to cross it. Then you walk along the riverbank. We walked past a farm, you know [Younger man: Yes], when we had rafted across there [Younger man: Yes], we came to the river. Started going, by a farm, you know, and there near the farm was a lowland, we went, managed to cross it again [Younger man: Yes], so I don't even remember exactly how we got to the Tornio River.

Generally, they did not have any watercraft. On one occasion, they crossed the river, for example, on a piece of roof that they had previously taken off a house - that was at night, with dogs barking. It was also difficult to cross a river, like the time when they used a boat found on the bank, but there were log rafts moving on the river.

They reconstruct events by reminding one another of them. The conversation partner's words are either confirmed by saying "yes!" now and then, or 
supplemented with details that the other can recall. Recollections are related by placing the escape journey events on the time scale in the specific geographical or perceptual space. In the former case, place names or river names are mentioned, in the latter case the talk is about the landscape and the buildings located there. However, the narrative episodes are most often related to body memory: they recall places where they felt cold ('we were trembling from cold in that hay barn'), fatigue ('we wanted to sleep, but we couldn't sleep there; there were so many evil mosquitoes'), thirst ('I had a water bottle in my hand, it was empty'). They remember places where they had to react bravely when meeting German or Finnish soldiers or even run away quickly, but also episodes, where they scared other people.

Recalling their escape journey, the war mates create a narrative that revolves around the desire to revive the course of real life events. This requires dividing the escape journey into episodes, but also structurally connecting the episodes to each other. The latter is achieved by following the sequence of the events and the geography of the journey. The narration of the story shows how factual information is based on body memory.

The culmination of the story is their arrival at the state border. Then the third part of the story follows: what they experience in Sweden immediately after crossing the border until they are assigned to their jobs. Having crossed the border, i.e., in Sweden, the autobiographical characters in the narrative undergo a change. While in the first and second parts of the story they are active individuals, now they turn into observers-describers of the "other" culture. Also, they do not act on their own, but something is done to or with them: they were sent on a train, taken to Stockholm, given something to eat, imprisoned for a few weeks, etc. Moreover, the story becomes more fragmentary: the men no longer remember what happened and how. They interfere with each other to discuss how it really was. There are no fixed points for telling a fluent story, as the men were no longer the decision-makers in their journey.

Older man: And then we got something to eat, we waited there... how long did we wait there before the police came?

Younger man: Didn't they make a call there?

Older man: ... Haaparanta, yes.

Younger man: I don't know what that was...

Older man: We sat there for about an hour...

Younger man: Definitely, that was definitely about an hour.

Older man: It wasn't far away; it was about three to four kilometres. 
Younger man: And then the police car came.

Older man: Then we were like gentlemen: we were taken to Haaparanta, and then were taken to the sauna; we had something to eat...

Younger man: I don't remember that either.

Older man: We came from the sauna, and were taken to spend the night; see, we were taken to prison...

Younger man: Listen to me, we were not taken to prison, not the first time, it was about one night or two nights that we slept in the police detention rooms.

Older man: Look, I don't remember that.

This is where the analysed story ends, as this was the end of the common period in the biographies of these men. From the aspect of this analysis, however, it is important to note that starting from the description of arriving at the state border and especially in Sweden, the reminiscing process and also the style of narrating changes. In the given case it is particularly significant, because the recording was made in a situation of spontaneous narration, which excluded the possibility of elaborating one's words (making it more artistic or expressive).

\section{TERRITORIAL AND SYMBOLIC BORDERS}

The analysed story shows the multi-dimensional nature of borders: how the narrators themselves perceive the borders, which borders appeared before them in the course of the events, which ones as a result of the choices they made on their own. As this is an episode that concentrates on crossing the state border between Finland and Sweden, we might ask: What is the state border like? It is discussed twice: firstly, the imaginary one, while discussing whether to escape; and secondly, when they actually reach the Finnish-Swedish border. The greatest difference between the imaginary border and the actual one is how the border looked - the recognition of the border. The younger man talks about the border in his imagination at the beginning of the story, when he recalls agreeing to the older companion's suggestion to escape to Sweden. He says:

I do remember the moment when you asked and I thought that I had never been to a border - what would the border look like anyway? - I thought there would be large high-wire fences, and sentry posts after every two or three metres, and I thought how we could ever go through such a place? 
The other man had assured him (he had been to the Estonian border and knew) that 'there are just a few wire fences; you can get through there all right'.

The actual border proved to be quite different. Early in the morning they came to a wide river they thought was the Tornio River, and Sweden was supposed to be on the other side of it. Yet, the men doubted if it was. Therefore, they started looking for signs that would confirm it was the border: the train's whistle heard on the other side of the river seemed different from that heard in Finland; also the landscape (forest stands, farms, plains, hay barns) looked different. Having crossed the river, they observed the landscape again: 'the grasslands were mowed, it was nice and tidy, you know, much different from what it was like in Finland'. What if it was just an island belonging to Finland, they wondered. Nevertheless, as they progressed along the road, they found a sign, the text on which they could not understand: 'That was in Swedish. Then we were sure we were in Sweden.'

The border resulted from the alteration of the status of the autobiographical characters: in one case they were fugitives, in the other, refugees. The emergence of this border in the narrative is supported by several aspects, including, for example, the role of objects in the story. During the escape, objects were aids (for example, in significantly numerous cases the water bottle and its refilling places and moments are pointed out). In the episodes depicting Sweden, objects became a part of descriptions of the culture - here the objects were subjects of observation.

At the level of the event, aspects of the border emerge that enable us to see the distinctness of the border. Besides that, however, the narrative also includes levels that can be viewed as symbolic aspects of the border. For instance, from the interpretive aspect, it is significant that they do not speak about crossing the state border only. Both the events, and the evaluations that the narrators give to the situation, result from the fact that Estonia was under foreign rule (German occupation during 1941-1944, Soviet rule during 1940-1941 and again during 1944-1991). They are Estonians who escaped to Finland to avoid conscription into the occupying German army, and then, both from conscription by the occupying German troops and from the potential Soviet threat, from Finland to Sweden. The border between Soviet Estonia and Sweden during the Cold War, when the story was narrated, is significant for understanding and interpreting the contents of the narrative.

It is namely within this political framework that they question whether their decision - to escape from the Finnish Army to Sweden in September 1944 - was traitorous or not (keeping Estonia and their companions in mind). But then again, were the young men who decided to return to Estonia wrong in their decision? In their discussion they cannot find an exclusively right answer to 
these questions. On the one hand, they do not regret their decision. They do not deny that if others had escaped too, in their words, 'about a thousand good Estonians' would have survived (this number - one thousand - refers to the young volunteers who perished either in later battles or in prison camps). They also point out the other side: if all Estonian volunteers had really decided to escape (i.e., not to return to Estonia), 'there would not be any [Estonian] history'. 'Just think,' they say, '2,000 men went against the great Russia' (approximately 1,800 volunteers came back to Estonia from Finland in August 1944; see Noormets 2011: 44). Therefore, there was the choice of whether to save the individual or Estonia, whether to develop their own life or the history.

To summarise, it can be said that escaping across the state border brought about a moral dilemma. There were two options to choose from: on the one hand, one's own life and self-realisation in a free society; on the other hand, an obligation (maybe an imaginary obligation) to participate in the history of Estonia as a soldier, whose only option is serving in a foreign army, as Estonia did not have its own army any longer. However, in a longer perspective, the escape also brought about borders in the social status of the men. In Sweden they were immigrants who at first did not even know the Swedish language. From the aspect of Estonian society, they also became 'others', those referred to as 'Estonians living abroad'. And furthermore, while their ancestors were Estonians, their descendants lived outside Estonia and did not speak Estonian.

It is obvious that at the level of events the border in this narrative becomes more noticeable when the change takes place within the autobiographical characters. At the same time, to recognise the border, the characters need hints and signs confirming that they have crossed the state border. At the level of evaluations and discussions, the border associated with the role changes (an Estonian in Sweden) fades away, while political borders in the Cold War context remain unambiguously clear.

\section{CONCLUSION}

The story analysed here reflects a view of the Finnish-Swedish border: how it was seen and perceived by two refugees at the end of World War II. The story is framed by the description of the border. Narrating the story starts with describing the imaginary border and the intention to cross the border, and ends with a detailed description of the crossing. Yet, the same story also contains other levels of border crossing. One way to recognise that they were in Sweden was seeing that the culture "here" was different, but also that the meadows and farm homes were different from those in Finland, which was at war. This, 
in turn, was connected with the fact that the Finnish-Swedish border marked the border of warfare. For these soldiers, it also represented the border between their fugitive status and freedom. In addition, the men discuss how to evaluate the border crossing from the standpoint of their own and their companions' life course. They evaluate their own fate in the biographical context: escaping gave them a possibility of self-realisation in a freer society, the alternatives to which they do not really know. What they say about the fate of their war mates falls into the political (and not biographical) context.

The recounted war period in their life lasted for slightly more than two years, and the escape journey within it just over a month. At the same time, this border crossing is one of the key points in the course of their lives. Although the general plan of the narrative is dedicated to the details of the escape journey, the narrative also reveals the reason why they want to recall and interpret this episode in their lives. They discuss the moral aspects of their decision, contemplating where their action is placed in the context of the other Finnish Boys (Estonians fighting in the Finnish Army) or in the context of the fate of Estonians in general; how to interpret their decision and their following life in the context of Estonian history.

Because the men were now reunited for the first time after the recalled events, this escape story had not been told in the same form before. As a spontaneous narrative, this story offers an opportunity to analyse the mutual relationship of the events and the protagonists and its role in the remembering process. The differences in the relations between the autobiographical "me" and the events come to the fore in the comparison of the situation before and after the border crossing. When describing their journey, although they were unable to determine and control the scenario of the events experienced during the journey, they describe every event, being the protagonists in it. Remembering the past was fluently expressed: they visualised the time and the place of activity (whether it was morning or evening, whether a meeting took place on the road or a bridge or in the forest). Based on this, the described situation was placed in the complete picture of the escape journey. However, when they described themselves as refugees in Sweden, they presented themselves as men in a passive state of expectancy (waiting for what would be done with/to them) and observers of the surrounding environment. They were no longer active in shaping the events, and the recounting of this period became fragmentary. They did not remember the key points that would have helped them create fluent episodes, in the context of the narrative. The positioning of the first-person character with regard to the events and the frames of interpretation (e.g. the moral aspects of their decision, comparison with war mates and compatriots) refers to the continuing process of shaping and conceptualising the experience. 
This narrative offers a chance to analyse the topic of the border, joining the border concept that has arisen from political geography with the poesy of placing the border into a narrative. On the one hand, it was apparent how the political-geographical and historical frameworks affected people's choices in moving from one place to another, and how this in turn shaped their subsequent course of life. Changes that had taken place both in one's biography and in society caused a need to look back at one's story once again - either to confirm or to review one's standpoints. At that level of the story, the qualities of (crossing) the border as a process were revealed. On the other hand, the poetic aspect of describing the border was emphasised. This included the features of depicting the time and space context of the events, for example, the feelings and bodily experiences of the main characters, the activity or inactivity of the characters in the course of the events, the personal and the unfamiliar cultural spaces. Although this narrative was not created for artistic purposes, it appeared that when describing the different aspects of the border (imaginative border, real state border, symbolic borders), inevitably also the style of presenting the story changed (e.g., the position of the main character, the way of observing and describing the environment).

\section{ACKNOWLEDGEMENTS}

The article was supported by the Academy of Finland, project Traumatized Borders: Reviving Subversive Narratives of B/Order, and Other (SA 297533), and the Estonian Ministry of Education and Research, project Tradition, Creativity and Society: Minorities and Alternative Discourses (IUT 2-43).

\section{NOTES}

1 Ii is a municipality of Finland. It is situated at the Bothnian Bay, at the mouth of the River Iijoki, and it is part of the Northern Ostrobothnia region.

\section{ARCHIVAL SOURCES}

EKLA 350 - manuscript collection of the Estonian life histories (1989-), Estonian Cultural History Archives at the Estonian Literary Museum, Tartu.

MK: Stockholm 2008, E. T. - materials collected by the author in Sweden in 2008, preserved at the Department of Estonian and Comparative Folklore, University of Tartu. 


\section{REFERENCES}

Allison, Randal S. 1997. Personal Experience Narrative. In: Thomas A. Green (ed.) Folklore: An Encyclopedia of Beliefs, Customs, Tales, Music, and Art. Vol. II. Santa-Barbara, California \& Denver, Colorado \& Oxford, England: ABC-CLIO, pp. 635-637. Available at http://www.rhymesworld.com/sitebuildercontent/ sitebuilderfiles/2285284.pdf, last accessed on 5 September 2018.

Apo, Satu 1995. Naisen väki: Tutkimuksia suomalaisten kansanomaisesta kulttuurista ja ajattelusta. [Female Väki-Force: Studies in Finnish Folk Thought and Culture.] Helsinki: Hanki ja jää.

Bluck, Susan \& Alea, Nicole 2008. Remembering Being Me: The Self Continuity Function of Autobiographical Memory in Younger and Older Adults. In: Fabio Sani (ed.) Self Continuity: Individual and Collective Perspectives. New York: Psychology Press, pp. 55-70.

Custred, Glynn 2011. The Linguistic Consequences of Boundaries, Borderlands, and Frontiers. Journal of Borderlands Studies, Vol. 26, No. 3, pp. 265-278. https:// doi.org/10.1080/08865655.2011.675716.

Jaago, Tiiu 2011. The Lucky Star and Discernment: The Positioning of the Self and War in the Life Story of Lembitu Varblane. In: Ene Kõresaar (ed.) Soldiers of Memory: World War II and Its Aftermath in Estonian Post-Soviet Life Stories. Amsterdam \& New York: Rodopi, pp. 317-342.

Kirss, Tiina 2006. Põgenemisteekonnad ja põgenemislood. [Escape Journeys and Escape Stories.] In: Tiina Kirss (ed.) Rändlindude pesad: Eestlaste elulood võõrsil. [The Nests of Migratory Birds: Life Stories of Estonians Abroad.] Tartu: Eesti Kirjandusmuuseum \& Toronto Ülikooli Eesti õppetool, pp. 611-646.

Lawler, Steph 2008. Stories and the Social World. In: Michael Pickering (ed.) Research Methods for Cultural Studies. Edinburgh: Edinburgh University Press, pp. 3249. Available at https://lcst3789.files.wordpress.com/2012/01/pickering_ed_ research_methods_in_cultural_studies.pdf, last accessed on 5 September 2018.

Leemets, Margus (ed.) 1997. Vabaduse eest. Soomepoiste lühielulood. [For Freedom: Brief Life Histories of the Estonian Volunteers in the Finnish Infantry Regiment.] Tallinn: Soome Sõjaveteranide Eesti Ühendus. Available at https://www.digar. ee/arhiiv/et/raamatud/81057, last accessed on 5 September 2018.

Mertelsmann, Olaf 2011. Boris Raag - Hope of Staying Alive: Survival Strategies of a Soviet Soldier. In: Ene Kõresaar (ed.) Soldiers of Memory: World War II and Its Aftermath in Estonian Post-Soviet Life Stories. Amsterdam \& New York: Rodopi, pp. 263-277.

Newman, David 2003. On Borders and Power: A Theoretical Framework. Journal of Borderlands Studies, Vol. 18, No. 1, pp. 13-25. https://doi.org/10.1080/0886565 5.2003.9695598.

Noormets, Tiit 2011. Estonians in World War II: A Chronology. In: Ene Kõresaar (ed.) Soldiers of Memory: World War II and Its Aftermath in Estonian Post-Soviet Life Stories. Amsterdam \& New York: Rodopi, pp. 35-46.

Paasi, Anssi 1996. Territories, Boundaries and Consciousness: The Changing Geographies of the Finnish-Russian Border. Chichester \& New York \& Brisbane \& Toronto $\&$ Singapore: John Wiley \& Sons. 
Palmenfelt, Ulf 2006. The Dark Shadow of the Un-Mentioned Event: Collapsing Taleworlds and Narrative Reparation. In: Annikki Kaivola-Bregenhøj \& Barbo Klein \& Ulf Palmenfelt (eds.) Narrating, Doing, Experiencing: Nordic Folkloristic Perspectives. Studia Fennica: Folkloristica 16. Helsinki: Finnish Literature Society, pp. 101-116.

Pickering, Michael 2008. Experience and the Social World. In: Michael Pickering (ed.) Research Methods for Cultural Studies. Edinburgh: Edinburgh University Press, pp. 17-31. Available at https://lcst3789.files.wordpress.com/2012/01/pickering ed_research_methods_in_cultural_studies.pdf, last accessed on 5 September 2018.

Schimanski, Johan 2006. Crossing and Reading: Notes towards a Theory and a Method. Nordlit, Vol. 19, pp. 41-63. http://dx.doi.org/10.7557/13.1835.

Schimanski, Johan \& Wolf, Stephen 2010. Cultural Production and Negotiation of Borders: Introduction to the Dossier. Journal of Borderlands Studies, Vol. 25, No. 1, pp. 38-49. https://doi.org/10.1080/08865655.2010.9695749.

Uustalu, Evald \& Moora, Rein 1973. Soomepoisid: ̈̈levaade Eesti vabatahtlike liikumisest ning sõjateest Soomes ja kodumaal Teise maailmasõja päevil. [Finnish Boys: An Overview of the Movement and War Experiences of Estonian Volunteers in Finland and Estonia during the Second World War.] Toronto: Soomepoiste Klubi Torontos.

Varblane, Lembitu 2011. Born Under a Lucky Star. In: Ene Kõresaar (ed.) Soldiers of Memory: World War II and Its Aftermath in Estonian Post-Soviet Life Stories. Amsterdam \& New York: Rodopi, pp. 163-185. 


\title{
METAPHORICAL INTEGRATIONS IN KURDISH RIDDLES
}

\author{
Rahman Veisi Hasar \\ Department of English Language and Linguistics \\ University of Kurdistan, Sanandaj, Iran \\ e-mail: veisirahman@yahoo.com \\ Ebrahim Badakhshan \\ Department of English Language and Linguistics \\ University of Kurdistan, Sanandaj, Iran \\ e-mail: badakhshane@gmail.com
}

\begin{abstract}
This paper aims at investigating the metaphorical integrations of riddles in the Kurdish language. For this purpose, 100 Kurdish riddles are analyzed according to the blending theory of metaphor (BT). Accordingly, the riddles are classified into three groups. The first one, which we call a contingent metaphor, involves those riddles shaped by metaphorical mapping between the precedent and the sequent as input spaces, which are then combined and compressed into the blend space. The linguistic structure of a contingent riddle includes the precedent space and some of the conceptual correspondences without any explicit reference to the sequent space. The possible candidates of the hidden sequent space are conditioned by the image-conceptual structure of the precedent space. The second group, which we call a discordant metaphor, includes those riddles that are based on a complicated metaphorical integration between the precedent and the sequent as input spaces: elements and relations of input spaces are cross-mapped, and then they are mixed and compressed into the blend space; and ultimately, a kind of disanalogy between spaces is brought about by backward projection. The linguistic structure of a discordant riddle includes two contradicting parts. The first part indicates the metaphorical integration, and the second shows the disanalogy. The candidacy of a possible sequent space is conditioned by the structure of the precedent space and by the differences highlighted by the backward projection. The metaphorical riddle in both groups is a specific kind of deliberate metaphor which invites the riddlee (addressee) to view (guess) the sequent in terms of the precedent. The deliberateness of the metaphorical riddle leads the riddlee to construct numerous metaphorical mappings between the precedent space and many possible candidates for the sequent space. The third group includes the non-metaphorical riddles not applying any kind of metaphor.
\end{abstract}

Keywords: blending theory of metaphor, contingent metaphor, discordant metaphor, Kurdish language, metaphor, riddle 


\section{INTRODUCTION}

The riddle is a very important and indispensable part of the Kurdish folklore in a sense that its cultural role might be traced back to the ancient mythologies in the Old Iranian era. According to one of the Iranian mythologies, a hero sacrifices one hundred horses, one thousand cows and ten thousand sheep for a goddess to help him to find the answers of some riddles (Khaleqi Mutlaq 2002: 169). The ancient idea of the riddle has been verbalized by many synonymous

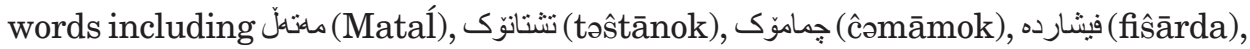
or شتى كانى (ŝtēkānē) in the Kurdish language. Among other words, the word təŝtānok may describe the very nature of the riddle more vividly; it literally means what-is-ness. In fact, it refers to the enigmatic nature of the riddle, and demonstrates the question-oriented discourse of the riddle. The riddle in the Kurdish culture contributes to many different social functions. The researchers (see Zolfaqhari 2013: 108-110; Ahmadi 2010: 14) have named many functions of the riddle in the Iranian culture including education, improving the intelligence of the children, entertainment, competition among people, and propagating the ideological and religious ideas.

The ethnic context in which riddles are mainly exercised is called $\hat{s} a w$ nəŝini in the Kurdish language; it literally means sitting around each other in the night. The Kurdish culture was mainly based on an agricultural society, and people were busy throughout the day. But they could use their spare time at night to tell stories (Bayt) or ask riddles. ${ }^{1}$ Elderly people were mainly narrators and riddlers, and younger ones were narratees and riddlees. With regard to riddles, elderly people as the holders of the ethnic wisdom ask riddles from younger ones to evaluate their familiarity with the ethnic heritage. The riddlers often promise a gift or a prize to those who can find the correct answer. In all areas of Kurdistan, the riddle is a common tradition. The Kurdish riddles mainly cover six general topics including information about physical objects, animals, plants, instruments, human beings, and religious-scientific knowledge (see Shohani 2014; Ahmadi 2010: 19-23). The Kurdish riddles, similar to riddles in other cultures, mainly have a kind of two-part structure: the question along with some clues and the hidden answer. In the following example, the riddle involves the question (or the question image) and the answer.

1. Yak pay hasu yak ĉāw.

It has one leg and one eye. (needle)

The riddle as such is combined of two parts, namely the precedent (the question or the question image) and the sequent (the answer of the riddle). The former includes some properties, images, propositions, or puns providing some clues 
for surmising the latter (see Harries 1971: 388; 1976; Dienhart 1999: 101-102). But, the relationship between the precedent and the sequent varies according to the figurative devices applied in the riddles. For example, in non-metaphorical riddles such as conundrums or puns it is the phonetic similarity (not a conceptual relationship) linking the precedent and the sequent (see Dienhart 1999). Adding to this, in most of the non-metaphorical riddles, the phonetic, syntactic, or semantic ambiguities are the "block elements" of the riddle, which should be removed to find the right answer. The removal of the block elements is done by referring to linguistic codes and grammatical limitations of a given language (see Green \& Pepicello 1984: 189). In other words, the riddlee tries to find the sequent by disambiguating the precedent. Let us have a look at the following examples:

2. What turns but does not move? Milk (from Dienhart 1999: 107).

3. Why is coffee like the soil? It is ground (ibid.).

In riddle 2 , the riddle is made by an ambiguous phonetic form (turn) having two different meanings (rotating and changing). The riddlee should disambiguate the word by choosing the second meaning (changing), which is compatible with the riddle. Also, in riddle 3 the ambiguity emerges as a result of the homophony between the noun lexeme of ground /grawnd/ and the past participle of the grind /graynd/ as the intended meaning in the riddle. Accordingly, the linguistic structure and the superficial elements in non-metaphorical riddles are especially important for analyzing the riddle. By removing the ambiguities, comparing the phonetic forms, or analyzing the grammatical errors, the riddle can be solved.

However, there are some riddles that may not be relegated to a kind of superficial linguistic ambiguity, simply because they are based on an underlying metaphor. Metaphorical riddles are based upon a cognitive comparison between the precedent and the sequent, consequently they may not be solved by eliminating the superficial ambiguities or grammatical errors. First the underlying comparison between the two parts is made, and next the linguistic structure is presented (see Green \& Pepicello 1984: 201). Köngäs-Maranda (1971) believes that there is an underlying metaphorical comparison between the elements of the precedent and the sequent prior to the genesis of the linguistic structure of the metaphorical riddle. Then, the given term as the precedent (the core of the riddle image) is compared to the hidden term as the sequent (the answer) according to some premises (the clues). The following table is presented by Köngäs-Maranda (ibid.: 17) to explain the metaphorical riddle of one pig two snouts (plough). 


\begin{tabular}{|l|l|l|l|l|}
\hline Terms & & Premise & Premise & \\
\hline & & constant & variable & \\
\hline Given & A pig & has snouts & two & image \\
\hline Hidden & A plough & & one & answer \\
\hline
\end{tabular}

As is evident in the above table, the metaphorical riddle is made by imageconceptual comparison, and may not be reduced to superficial linguistic features. The conceptual aspects of the metaphorical riddles should be explained from a cognitive perspective. For this purpose, let us review the concept of metaphor and its relevance to the riddle in cognitive semantics.

Metaphor as a cognitive omnipresent phenomenon satisfies many heterogeneous functions. Its functions range over a variety of cognitive abilities, from understanding and feeling (see Lakoff \& Johnson 2003 [1980]; Lakoff 2007; Kovecses 2004 [2000]) to conceptualizing the socio-cultural and theological experiences (see Kovecses 2005; Musolff 2004; Gomola 2010; El-Sharif 2012). Besides all these extremely important functions, metaphor can play an important role in a different cognitive ability, namely guessing. If the metaphor is utilized for understanding and experiencing one concept (target domain) in terms of another (source domain) (Lakoff \& Johnson 2003 [1980]: 5), it may also be used for guessing one kind of thing in terms of another. The metaphorical guessing is realized in the metaphorical riddles. In this regard, the riddle is characterized as a metaphorical cognitive phenomenon beyond its linguistic manifestations. Therefore, the given precedent and the hidden sequent are interpreted as the source and target domains respectively, and the premises are read as the linguistic manifestations of the conceptual correspondences between the domains. Then, the metaphorical riddles are based on the conceptual mapping between the precedent as the source domain and the sequent as the target domain. For example, the metaphorical riddle Which is the animal that has four feet in the morning, two at midday, and three in the evening? is based on conceptual mappings among precedents including day and journey and sequents involving life of a human and human life respectively (see Kovecses 2010 [2002]: 11). Consequently, this riddle is based on conceptual metaphors of "THE LIFE OF HUMAN BEINGS IS A DAY" and "HUMAN LIFE IS A JOURNEY". The linguistic manifestation of the riddle includes the source domain (precedent) and some of the conceptual correspondences without any explicit reference to the sequent. With regard to the hiddenness of the sequent part, the metaphorical correspondences between the domains are accomplished by the riddlee's guessing. In other words, it is the riddlee who makes various metaphorical correspondences between the source domain (precedent) and the 
target domains (the possible candidates for the sequent) according to his or her guesses. Composed of explicit image-concepts and a hidden answer, the metaphorical riddle invites the riddlee to guess the latter in terms of the former. In other words, the riddler presents a kind of deliberate metaphor (see Steen 2011: 84) whereby he or she asks the riddlee to view and guess (consciously) the latter (target domain) in terms of the former (source domain) on the basis of a metaphorical comparison.

The blending theory (see Fauconnier \& Turner 2002) as a cognitive theory can explain the complicated cognitive process underlying the metaphorical riddles in more detail. Let us illustrate this theory via explaining the metaphorical integration of the ECONOMIC COMPETITION IS A BOXING MATCH as a conceptual metaphor. According to this theory, every metaphor is composed of four conceptual spaces including two input spaces, the generic space, and the blend one. Accordingly, the input spaces consist of the space of economic competition and that of a boxing match. Also, there is a generic space which involves the shared elements of the input spaces (two opponents, the same goal, and the competition). It is the generic space that makes the metaphorical integration possible; in other words, no integration between the input spaces would be accessible without some shared abstract properties. Finally, there is a blend space in which the elements of the input spaces are combined and compressed; the final conceptual fusion brings about the conceptual metaphor. Therefore, the metaphorical riddle may be seen as a kind of conceptual integration; the precedent and the sequent as input spaces are cross-mapped, and consequently they are combined and compressed into the blend space to give birth to a fusional metaphorical construction (see Fauconnier \& Turner 2002: 119, 49; Rapone 2012). Accordingly, a metaphorical riddle involves four spaces: the precedent and the sequent as input spaces, the blend space (the metaphorical fusion of the inputs), and the generic space (shared elements of the input spaces). As Rapone (2012) puts it, one of the input spaces as the sequent is implicit, but the precedent as the explicit input space, the blend space, and the generic one may supply some clues for the riddlee to guess the hidden sequent space. By relying on information from these three spaces, the riddlee can guess the right answer.

Owing to the lexical and structural ambiguities of the riddle, they may have more than one answer. The procedure of guessing the sequent for both the metaphorical and non-metaphorical riddles is determined by potentiality and indeterminacy. In other words, the clues are not always sufficient for pointing out the specific sequent existing in the mind of the riddler. Accordingly, there may be more than one possible candidate (for the sequent) that can satisfy the clues presented by the precedent. It is because of this that determining the right sequent is always dependent on the will of the riddler (see Ben-Amos 1976: 249). For example, let us look at a non-metaphorical Kurdish riddle. 
4. Helka daka, mriŝk nya.

It lays eggs, but it is not a bird. (turtle)

The answer to this riddle can be turtle, lizard, or even fish. It is the riddler who determines which one is the correct sequent. The potentiality of the sequent refers back to the insufficiency of the clues in the precedent. It should be noted that in some occasions, the riddler intentionally uses ambiguous and vague words in order to deceive the riddlee (see Weiner \& Palma 1993: 189).

The riddle is always based on a reciprocal interaction between potentiality and cognitive operation of guessing. Therefore, any research on the riddle should take the dialectics of cognition and potentiality into consideration. In other words, it should illustrate the potential metaphorical integrations presented by the riddlee's guesses motivated by the ambiguous and indeterminate structure of the riddle. In this regard, the present paper aims at scrutinizing the metaphorical structure of the riddles in the Kurdish language by applying the blending theory of metaphor. It tries to show the triangular dialectics of the metaphor, guessing, and potentiality in Kurdish metaphorical riddles. The riddles under consideration are common in Kurdistan of Iran. They are used by people in different cities like Sanandaj, Boukan, and Saggez.

In addition to the introduction, the present article is comprised of four chapters. The first one spells out the methodology of the paper in detail, the next deals with the typology of the riddles in the Kurdish language. In this chapter, the conceptual structures of the riddles are explained according to the blending theory. The third chapter presents some implications for the process of metaphorical guessing, and finally, the conclusion sums up the results and implications of the paper.

\section{METHOD AND MATERIALS}

The data of the present study are based on a Kurdish dictionary of riddles (Sarseyfi 2010). The book involves 600 riddles along with their answers. Each entry involves a riddle and its answer. Among all the entries, 100 riddles were selected randomly from the alphabetical list of the dictionary. The linguistic structure of each riddle involves the precedent and the clues, and lacks any kind of explicit reference to the sequent (answer). By investigating the relationship between the riddles as the precedent and their answers as the sequent, this paper tries to elucidate their possible metaphorical relationships. The paper attempts to shed light on the ways the precedents refer metaphorically to the hidden sequents in the riddles. 
To recognize the metaphorical usage of the words in the riddles, the method of metaphor identification procedure (MIP) (see Pragglejaz Group 2007) was applied. According to this method, if the contextual meaning of a word contrasts its basic meaning, and also if the former is understood in comparison to the latter, the word is marked as metaphorical. How can this method be applied to riddles? To illustrate this procedure, let us consider two entries of the book (Sarseyfi 2010).

5. Qalây gači ret nya bəči.

A plaster castle, you cannot enter it. (egg)

6. Žən nya pyâwiŝ nya, be dâyku bâbî̀ nya.

It is not a woman (a married one) and not a man (a married man), it has father and mother. (a single girl)

Considering riddle 5, the precedent includes the phrase plaster castle. The basic meaning of this phrase refers to a kind of building. But the precedent of plaster castle refers figuratively to a white egg (the sequent) in this riddle. Thus, it can be argued that the contextual meaning of the plaster castle in this riddle is white egg. Besides, the contextual meaning (white egg) is in contrast to the basic meaning (a kind of building); furthermore, the former is understood in comparison to the latter. Regarding MIP, it can be concluded that the plaster castle is used metaphorically in this riddle. Consequently, we regard the literal meaning of the precedent as its basic meaning, and consider the sequent as its contextual meaning in the metaphorical riddles.

But in riddle 6 , the words in the precedent part are not used metaphorically. The precedents including woman, man, father, and mother, and the sequent involving a single girl are not understood in comparison to each other. However, they are related to one another in terms of some distinctive features such as male, female, married, and single. Besides, the sequent may not be the contextual meaning of the precedents, but they are separate meanings that are related to each other in terms of some superficial linguistic ambiguities. Therefore, the precedent of non-metaphorical riddles does not satisfy the conditions of MIP.

To analyze the conceptual integrations of the metaphorical riddles, the blending theory of metaphor (Fauconnier \& Turner 2002) was applied. In this regard, the entry as the precedent and the answer as the sequent were considered as the input spaces. The metaphorical output brought about by fusing the input spaces was considered as the blend space. The common properties of the input spaces were regarded as the generic space. The linguistic manifestation of the riddle contains the input space of the precedent, and also some elements of the blend space, but it lacks any kind of direct reference to the hidden sequent space. The entries along with their answers are arranged in the following table: 


\begin{tabular}{|l|l|}
\hline Metaphorical riddle & \\
\hline The riddle as the precedent & The explicit input space \\
\hline The answer as the sequent & The hidden sequent space \\
\hline $\begin{array}{l}\text { Shared properties between } \\
\text { the precedent and the sequent }\end{array}$ & The generic space \\
\hline $\begin{array}{l}\text { Metaphorical relation between } \\
\text { the precedent and the sequent }\end{array}$ & The blend space \\
\hline
\end{tabular}

After inserting different parts of the metaphorical riddles in the above table, we tried to illustrate different styles of metaphorical integrations in the riddles. It should be noted that the primary concern of this paper is to uncover the underlying conceptual structure of the Kurdish riddles; accordingly, we do not delve into analyzing their linguistic properties.

\section{TYPOLOGY OF KURDISH RIDDLES}

By analyzing the data according to the abovementioned methodology, it became evident that there are at least three different kinds of riddles, two of which can be categorized as metaphorical riddles with different conceptual structures, and the third one may be classified as non-metaphorical riddles. Let us take a look at the following cases characterizing these three groups.

7. Tâli hawreŝm, har lerawa tâ baghdâ aykeŝm.

A silk thread, I pull it from here to Baghdad. (road)

8. Gâyakm haya gâ bâri, nagoŝti daxore na bāri.

I have a cow that has a great load on its back; its meat and its load can't be eaten. (scarab beetle and its dung ball)

9. Hana no sini, ba har sini no nân, la sar har nân no kəfta, la sar har kəft no korpa.

I have nine trays, and nine loaves of bread on each tray, and nine kəftas (a kind of food) on each loaf of bread, and for each kəfta, there are nine kinds to feed. (81 loaves of bread, 799 kəftas, and 6561 children)

Regarding riddle 7 as a member of the first sub-group of the metaphorical riddles, the phrase long silk thread has been used metaphorically, because the contextual meaning of the silk thread in this riddle (road) is different from its basic meaning (a kind of thread); besides, the former contrasts the latter, and the road is understood in comparison to the silk thread (for MIP see Praggle- 
jaz Group 2007). Then, it is concluded that this riddle is a metaphorical one. Consequently, it can be argued that the riddle includes the input space of (silk thread) as the precedent and that of (road) as the sequent. In the blend space, the image of the long silk thread and the image of the long road are compressed and combined with one another. The generic space of this conceptual integration involves shared properties like a geometrical shape of a long line. The sequent space of road is not explicit in the riddle, but the precedent space of long silk thread and its shared properties with the image of the road are presented in the riddle. The riddle provides the information for the riddlee to guess the road in a metaphorical way.

Considering riddle 8 as a member of the second sub-group of the metaphorical riddles, the word cow is used metaphorically. The contextual meaning of cow (which is scarab beetle) contrasts its basic meaning (a mammalian animal). Also, the former (scarab) as the contextual meaning is understood in comparison to the latter (cow) as the basic meaning. Accordingly, this riddle is a metaphorical one. The word load may not be regarded as a kind of metaphorical word because the load carried by the cow is not in contrast to the dung ball as a load carried by the scarab. The dung ball itself is a kind of load, so it is the hyponym of the load. Therefore, this riddle is a metaphorical one, simply because of the metaphorical relationship between cow and scarab.

The precedent including the cow and its load is mapped onto the sequent involving the scarab and its dung ball, and then they are combined and compressed into the blend space. The generic space contains the carrier and an object (the carried thing). The metaphorical integration between the precedent and the sequent is stated in the first part of the riddle in which the scarab beetle is described as a cow carrying a load. However, the second part of the riddle causes a disanalogy between the spaces. It says that the meat of this cow (scarab) cannot be eaten. According to Islamic rules, eating the meat of the cow is legitimate, but eating the scarab beetle is forbidden. Accordingly, it states that although the scarab beetle resembles the cow in some respects, the former is not edible. The second part of the riddle aims at highlighting the differences between the cow and the scarab beetle. Then, this riddle simultaneously makes a metaphorical analogy between the precedent and the sequent, and then highlights a disnalogy between them. How does this disanalogy occur along with the metaphorical integration between the precedent and the sequent? How can this complicated metaphorical structure be explained in terms of cognitive terminologies? In the chapter about discordant metaphors we tackle this problem in detail.

Example 9 as a member of the non-metaphorical riddles (the third group) includes a kind of mathematical computation. The words are not used meta- 
phorically in this example because the contextual and the basic meanings of the words are the same. Furthermore, the sequent is not understood in comparison to the precedent. In contrast, the sequent can be found via a mathematical computation of the precedent. All the other data are classified into these three groups.

Accordingly, it can be argued that the riddles existing in the book may fall into three different groups. The first group includes the riddles specified by a metaphorical relationship between the precedent and the sequent according to a kind of similarity between them. However, the second group includes those riddles containing a metaphorical relationship between the spaces along with a disanalogy between them. They consist of two contradictory parts: the first one shows the metaphorical relation between the precedent and the sequent, and the second one demonstrates a kind of contradiction between them. The only distinctive feature distinguishing the first and the second group of metaphorical riddles refers back to the disanalogy made in the second part of the riddle. The third group involves those riddles representing the answer in a non-metaphorical manner. The first group (illustrated by example 1) includes 37 riddles; the second group (see example 2) contains 30 riddles, and the third group (non-metaphorical riddles) involves 33 riddles. So, the first group constitutes about 37 percent, the second one about 30 percent, and the third one about 33 percent of all the riddles. In the following sections, we try to scrutinize the conceptual metaphorical structures of these groups in detail.

\section{The first group: Contingent metaphors}

The first group comprises 37 percent of the total number of riddles. It contains those riddles that are constructed by a metaphorical relationship between the precedent and the sequent. Consequently, the precedent space is mapped onto the sequent space. Then, they are mixed and compressed with one another in the blend space. The sequent space is not explicit in the linguistic structure of the riddle; therefore, the riddlee should guess the hidden sequent space mainly in terms of the conceptual and image-schematic properties of the precedent space. There are some other examples as follows:

10. Âsmâni nazmoka, ley dabəre bafroka.

A near (low) sky from which snow is falling. (the sieve (and the flour falling from it))

11. Ble am ŝera hâsâna, mriŝkiŝ hali dene.

Say this easy poem that can be recited by a hen. (egg) 
12. Kołakayakyân haya ba du mât.

Two houses have just one column. (two nostrils and the septal nasal cartilage between them)

13. Tawilayakəm haya, diwâri čarma, siwdu mař teydâ, beharâw gərma. I have a stable, with a wall of leather, thirty-two sheep are there quietly. (mouth, cheek, and teeth)

14. Kar mardu, bâr zandu.

The donkey is dead, and the load is alive. (cradle and a baby)

15. Du mâri řâs, du črây gaŝ, du kona rewi, âw ley roi.

Two black snakes, two bright lamps, two fox dens through which water is passing. (eyebrow, eyes, nostrils, and nasal mucus)

16. Bâni hasâna, źeri qorâna.

Its upper surface is grindstone and its lower surface is Quran (a book). (mushroom)

\section{Du âw la Jâme.}

Two kinds of liquid in a cup. (egg with its white and yellow liquids)

18. Wak goy zawi wâya, wargi pəř la hawâya, hatâ tey hal day, aw la samâa.

It is like an earth globe, its belly full of air, if you kick (its ass) it will dance. (ball)

19. Ŝâreki ŝina, čwâr dawri sawza, xaĺki rangarang, newakay hawza. There is a green city that is surrounded by green walls, the people are in different colors, and there is a pool at the center. (water melon)

In riddle 10, the words are applied metaphorically. For example, the contextual meaning of the sky (sieve) contrasts its basic meaning (the space above the earth), and the former is understood in comparison with the latter. Just in the same way, the basic meaning of the snow (white pieces of the frozen water) is turned into the contextual meaning of the flour; and the flour is understood in comparison with the snow. This metaphorical riddle is shaped by a metaphorical mapping between the input spaces of sky and sieve. The precedent space includes mental images of the sky, white snowflakes, and also a dynamic image of snowing; and the sequent space involves a sieve, white particles of flour, and the falling of flour particles from the sieve. The elements of the input spaces are cross-mapped respectively, and then they are combined and compressed into the blend space. The generic space includes the shared elements such as a container, white matter, and a descending movement. This metaphorical riddle is based on such a conceptual metaphorical integration. 
The riddlee should find the right answer by examining different possible candidates (for the sequent space) that can integrate metaphorically with the precedent space. There are many possible candidates that bear similarities to the structure of the precedent space, and can participate in a metaphorical integration with it; therefore, the riddlee can imagine several possible answers for this riddle. For example, the snowflakes can be mapped onto salt particles, plaster particles, or onto other white materials which can be sifted. Also, the near sky can be mapped onto the salt shaker and other kind of sieves. Consequently, this riddle is specified by potentiality and indeterminacy of the sequent space, and may have more than one answer. But the riddlee wins, when he or she guesses the intended sequent space in the riddler's mind. As Ben-Amos puts it (1976: 249), it is the will of the riddler that determines the right answer of a riddle having many different potential answers (sequents). Then, there are many possible sequent spaces that are conditioned by the image-conceptual structure of the precedent space. Because of this contingency, the riddlee has to guess several times. No one loses the game by saying the false answer. They can guess several times until they find the right choice.

As for example 11, the words of poem and reciting the poem are used metaphorically. The contextual meanings of the poem and reciting the poem refer to egg and egg laying, and the contextual meanings contrast their basic meanings; and also the former is understood in comparison to the latter. A kind of metaphorical integration is made between the precedent space including the elements of a poet, recitation, and its product (a poem) and the sequent space involving a hen, egg laying and its product (the egg). The elements of the input spaces are cross-mapped, and then compressed and combined in the blend space. The generic space includes the shared elements like the producer, production, and the product. It is worth mentioning that one of the elements of the sequent space, namely hen, is evident in the riddle, but the hidden answer (egg) is not explicit.

The riddlee tries to guess the sequent by considering the precedent (poem and poet) and also by regarding one of the conceptual correspondences (hen as a poet reciting a poem). The riddlee should find an appropriate candidate suitable for mapping and blending with the precedent. Yet, there are some possible candidates other than the one determined by the riddler. For example, cluck is a good candidate for the poem of a hen, although it is not chosen by the riddler as the correct answer. The meat of a hen can be imagined as another candidate. After examining these possible sequents, the riddlee should choose the egg as the intended answer.

In riddle 12, the words column and house are applied metaphorically. Their contextual meanings (the septal nasal cartilage and nostril) contrast their basic 
meanings (a long solid stone and a building); and also, the former is understood in comparison to the latter. The precedent space involves the image of two houses having a same column, and the sequent space contains the image of two nostrils plus their septal nasal cartilage. The input spaces are crossmapped, and then combined and compressed into the blend space. Accordingly, a fusional metaphorical image emerges in the blend space. The generic space involves a kind of bipartite container. The riddlee should find out the intended sequent according to the clues supplied in the riddle. Besides the intended answer, several potential candidates can be imagined as the sequent space by the riddlee. For example, there is a traditional wooden cabinet in Kurdistan that has two rooms which are separated by a wooden column. It is another image which can be mapped onto the precedent space.

The words in riddle 13 are used as metaphorical words. The basic meaning of the stable refers to a kind of room in a building, but its contextual meaning in this riddle refers to the mouth. Although the basic meaning of the wall is a kind of structure, it refers to the cheek in this riddle. Finally, the contextual meaning of sheep is the teeth, while its basic meaning refers to a farm animal. All the contextual meanings of these three words are understood in comparison to their basic meanings. Accordingly, this riddle is based on three related metaphors in which the precedents of the stable, the wall, and the sheep are cross-mapped with the sequents of the mouth, cheek, and teeth respectively; consequently, they are mixed and compressed into their blend spaces. The generic space for the input space of the stable and the mouth includes an abstract container. Also, the generic spaces for the input spaces of the wall and cheek and the sheep and teeth include a flat structure covering a space, and some white round entities respectively. The large number of metaphors and clues in this riddle highly restricts the range of possible candidates for the sequents. The presence of another hint (with a wall of leather) intensifies this restriction. It implicitly describes the wall (cheek) as something made out of meat.

In riddle 14, the words donkey and load are used metaphorically because their contextual meanings (cradle and baby) contrast their basic meanings (an animal and a thing), and also, the former are understood in comparison to the latter. The precedent space includes the elements of a dead donkey and its load, and the sequent space contains the cradle and the baby. The generic space involves the abstract concepts of the carrier and the carried thing. The input spaces are cross-mapped, and then combined and compressed in the blend space. As the cradle is an inanimate entity, and the baby is animate, the riddle says the donkey is dead and the load is alive. The linguistic structure of the riddle includes the precedent space (donkey and load) and some of the metaphorical correspondences (the deadness of the cradle has been projected 
onto the donkey, and the animacy of the baby is projected onto the load). The riddlee should guess the predetermined sequent in terms of the precedent space and the explicit correspondences. Besides the cradle and the baby, several other potential sequent spaces can be imagined that may be mapped onto the precedent space. For example, a car and its driver, a bicycle and a rider, and even a bed and a human can be possible candidates for the sequent space.

The other examples in a similar way include a kind of image-conceptual integration, in which the input spaces of the precedent and the sequent are cross-mapped, and then are compressed in the blend space. In most of the cases, the riddlee can imagine many possible candidates for the sequent space, because many different candidates can take part in the conceptual integration with the precedent. So the process of guessing is not directed by a kind of logical necessity, but by a kind of potentiality and possibility, conditioned by the conceptual and image structure of the precedent space. The riddlee should examine many spaces as the possible candidates for the sequent space to guess the answer. Regarding the numerous candidates which may bear resemblance to the precedent, and can participate in a metaphorical integration with the precedent, the riddlee may guess more than one answer. It is worth taking into consideration that this possibility is conditioned by the general structure of the precedent. Due to this conditioned possibility, we call them contingent metaphors.

The parallelism between conceptual and image structures of the precedent space and the sequent one is the basis of this metaphorical integration. Considering the distinction between resemblance metaphors and correlation-based metaphors (Grady 1999), it can be argued that these metaphorical riddles are categorized as resemblance metaphors, because they are not motivated by any kind of experiential correlation between the spaces. They are based on a perceived similarity between the precedent and sequent spaces by the riddler. This resemblance is completely construed by the subjective perceptual judge of the riddler, and is not a pre-determined fact. The following diagram illustrates the conceptual integration of the riddles with contingent metaphors.

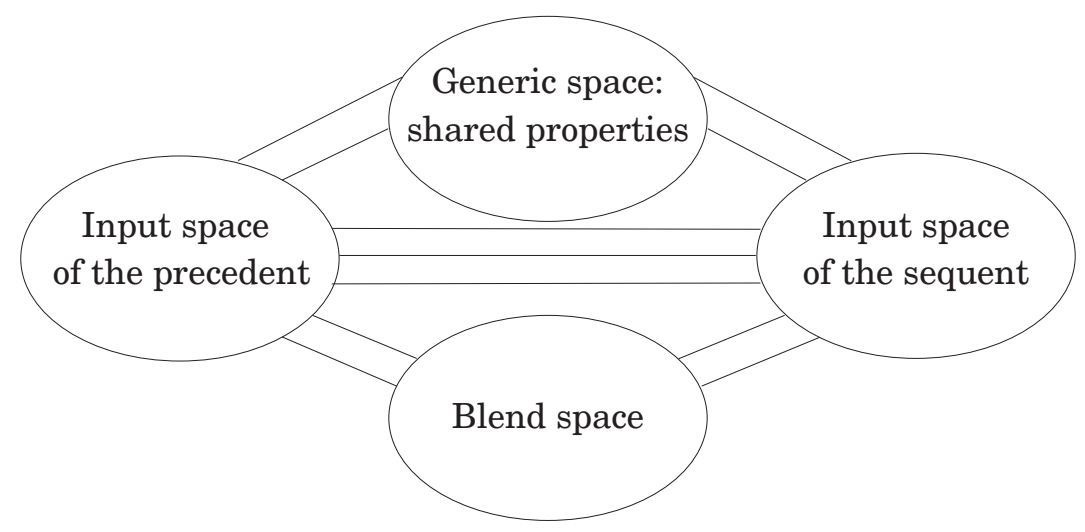


The linguistic manifestations of these riddles include the precedent space and some of the conceptual correspondences as clues for guessing the sequent space. Yet, the riddle does not refer explicitly to the hidden sequent space. When the riddlee mediates this kind of a riddle, he or she first considers it as a deliberate metaphor. As regards a deliberate metaphor, the speaker consciously "invites ... the addressee to ... set up a cross-domain mapping ... in order to view one thing in terms of something else" (Steen 2011: 84). The speaker invites the addressee to view the sequent space from the perspective of the precedent space. Accordingly, metaphorical riddles as deliberate metaphors invite the riddlee to guess the hidden sequent in terms of the conceptual and image-schematic properties of the precedent space. The deliberateness of the riddle leads the riddlee to make a metaphorical mapping between the precedent and any possible candidates for the sequent space.

\section{The second group: Discordant metaphors}

The second group comprises 30 percent of the total number of riddles. As mentioned, it includes two contradictory parts: the first part presents a metaphorical analogy between the precedent and sequent spaces, and the second one highlights a kind of disanalogy between them. Because of this contradiction, they are called contradictory riddles in the traditional classification (see Ahmadi 2010). These riddles use contradictory expressions for pointing out the intended answer. There are some other examples as follows:

20. Ârdi hâryâw, âs naditu.

It is the milled flour, but has not been milled in a water mill. (snow)

21. Aw bar dâwew âws nya.

She delivers a baby, but she is not pregnant. (ear and earwax)

22. Mângâyaki bekaĺu gwân, siirân dada ba hamuwâ.

It is a cow producing milk for everyone, but it has no udder. (bee)

23. Bahri du rang, na ŝapoli haya na dang.

A sea with two colors, but without any noises and waves. (egg)

24. Krâsi xayât naditu, ârdi âsyâw naditu, dâri najjâr naditu.

A cloth (fabric) not sewn by a tailor, flour not milled by a water mill, wood not worked out by a carpenter. (oleaster)

25. Zəmāni nya, qəsān dakā.

It has no tongue, but it can speak. (pen) 
26. Na gaday haya na pâze, boy dačeta sar bane.

It has no belly and feet, but can go up to the roof. (smoke when it goes up)

27. Korekmân habu bedastu pâ.

We had a boy, he had no hands and feet. (egg)

28. Bolboleki xoŝâwâza, balam palawar nya.

It is a nightingale with nice songs, but it is not a bird. (târ, a musical instrument)

29. Klâwek be taqalu derumân.

It is a hat that is not sewn. (the eggshell on the head of a chicken)

The words are used metaphorically in riddle 20 , simply because the contextual meaning of the milled flour (snow) contrasts its basic meaning (powder of wheat), and also the snow as the contextual meaning is understood in comparison to the flour. The riddle includes two parts: the first describes the snow as a kind of milled flour; and the second says that this specific entity is not milled in the water mill. In fact, the riddle wants to visualize the sequent via contradictory phrases. First, let us consider the opening part of the riddle, which embodies the metaphorical integration between the precedent and the sequent. The riddle in the first section is based on a metaphorical integration between the precedent space including particles of flour and the sequent space involving snowflakes. These two input spaces are cross-mapped, with the result that snow corresponds to flour, the whiteness of snow to the whiteness of flour, and the fineness of snow to the fineness of flour. These relations and elements are combined and compressed into the blend space. The generic space includes the shared properties like tiny and white entities. This metaphorical integration is stated in the first part of the riddle which describes snow as milled flour. Now let us scrutinize the second part. The riddle in the second part makes a disanalogy between flour and snow. It says that this kind of milled flour (snow) has not been milled in a water mill. It means that, whereas the tiny particles of snow closely resemble the particles of the milled flour, the former is not milled by using a water mill. The second part highlights an important difference between the milled flour and the snowflakes. The first part refers to the metaphorical analogy between the precedent and the sequent, and the second one highlights a kind of contrast and disanalogy between them. The question is how this disanalogy becomes possible in spite of the pre-established metaphorical analogy. The disnalogy between the input spaces becomes visible by the process of backward projection from the blend space to the input spaces. The backward projection brings about disanalogy between spaces; it disrupts the compression and presents a powerful contrast between the spaces (see 
Fauconnier \& Turner 2002: 49, 308). Therefore, the disanalogy in this riddle emphasizes the difference between snow and flour, and makes a kind of conceptual distance among the pre-combined elements in the blend space. Via this disanalogy, the second part can show the differences between snow and flour by highlighting an important property of the second input space (being milled in a water mill) that is excluded from the blend space. Although, the procedure of integration brings the spaces together in a metaphorical way, the backward projection makes conceptual distance among them by highlighting a radical difference. Accordingly, the second part of the riddle manifests the decompression and disanalogy made by the procedure of the backward projection. The following diagram shows this complicated system of integration.

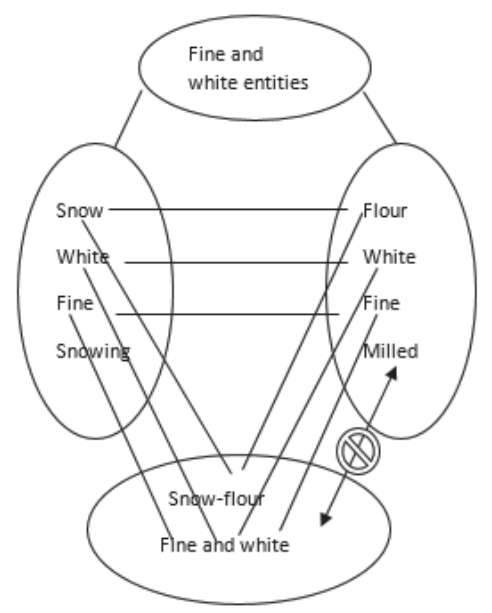

The arrow with the stop symbol directed from the blend space to the second input space depicts the process of a backward projection. It illustrates the process of highlighting the excluded property that seems like a surplus to the tight integrated system.

This diagram illuminates why this riddle cannot be explained by the conceptual metaphor theory (CMT), for this conceptual integration network is more than establishing a metaphorical integration between snow and flour. Besides the metaphorical integration, it provides disanalogy and decompression between the spaces by a backward projection. Because of these two simultaneous discordant processes, it seems that this metaphor denies some parts of itself. The linguistic structure of this riddle includes two parts that indicate the metaphorical integration and the disanalogy made by the backward projection. Although snow is not stated linguistically, it is integrated metaphorically with the flour in the first part of the riddle, and is implicitly contrasted with the milled flour 
in the second part. So the riddlee may use these two clues (metaphorical analogy in the first part and the disanalogy in the second part) to guess the hidden sequent space of snow. He or she tries to find a concept as an apt candidate for the sequent space which can take part in a metaphorical integration with flour, and also participate in a disanalogical relationship with the precedent.

The words in riddle 21 have been applied metaphorically, mainly because the contextual meanings of the woman and delivering a baby (ear and delivering the earwax) are in contrast to their basic meanings (a female human and bearing a baby), and, furthermore, the former are understood in comparison to the latter. This riddle includes two input spaces - pregnant woman as the precedent space and ear as the sequent space. Moreover, the potentiality of a woman to deliver a baby is compared to the potentiality of the ear to deliver earwax. The generic space includes the abstract concepts of the producer and the product. Then, the elements of these two input spaces are combined and compressed in the blend spaces. Consequently, a kind of metaphorical fusion is brought about. This is the result of the metaphorical integration between the input spaces. But in the second part, the riddle says that this entity delivers a baby, but it is not pregnant. In other words, it says that although as a pregnant woman it delivers a baby, it is not pregnant. Accordingly, some aspects of the metaphorical integration network are decompressed. This disanalogy between spaces is brought about by a backward projection from the blend to the inputs. It highlights the radical difference between the ear and the pregnant woman via highlighting the non-pregnancy of the ear in the sequent space. The linguistic structure of the riddle involves two parts: the first one indicates the metaphorical integration, and the second one illustrates the disanalogy. The concept of ear is not announced linguistically, but it is integrated with a pregnant woman in the first part, and implicitly contrasted with it in the second part. The riddlee should guess a candidate for the hidden sequent space that can take part in both of these processes.

In riddle 22 the words are used metaphorically. The contextual meaning of cow (bee) is in contrast to its basic meanings (a mammalian animal). Also, the former is understood in comparison to the latter. The riddle includes a precedent space including a cow and its milk and a sequent space involving the bee and its honey. The generic space includes the producer and its product. The precedent and sequent spaces are combined and compressed in the blend space. However, a kind of disanalogy between them is made by a backward projection. Accordingly, it says that this specific cow (bee) has no udder. The first part of the riddle contains a metaphorical integration, and the second one involves a disanalogy between the cow and the bee. The hidden sequent space should be guessed by considering these two parts. 
In riddle 23 the words are applied metaphorically. The contextual meaning of sea (egg) is in contrast to its basic meaning (a large area of water), and it is also understood in relation to the basic meaning. This riddle includes two input spaces of the sea as the precedent and the egg as the sequent. The generic space includes the abstract concepts of a container and liquid. The sea liquid is mapped onto the egg liquid, and then both are combined and compressed into the blend. Consequently, the egg as the hidden sequent space is described as a kind of sea in two colors (yellow and white). However, when the metaphorical integration is completed, a kind of disanalogy between the spaces is made by a backward projection. Accordingly, it says that while the egg liquid is described as the sea, it has no waves or sough. In other words, it wants to make a contrast between the sea liquid and the egg liquid. Then, it highlights the calmness and immobility of the liquid of the egg in contrast to the wavy and restless water of the sea. The riddlee should guess the sequent space by considering these contradictory descriptions made by a metaphorical integration and backward projection.

Riddle 24 includes metaphorical words too as the contextual meanings of the words (skin of oleaster for the cloth, seed for wood, dry flesh of oleaster for flour) contrast with their basic meanings, and also the former is comprehended in comparison with the latter. This riddle includes more than one integration network. The riddler wants to specify oleaster by different metaphors. First, he or she makes metaphorical integrations between the skin of oleaster and a cloth, between its seed and wood, and then between dry flesh of oleaster and flour. But there are also some disanalogies between all these integrated spaces by some backward projections. Via backward projections, it makes disanalogies between the cloth sewn by a tailor and the skin of oleaster not sewn by anyone, between the milled flour and the dry flesh of oleaster (which resembles the flour, but is not milled), and between the wood worked out by a carpenter and the wood-like seed of the oleaster not worked out by any carpenter. The riddlee tries to guess oleaster by considering all these metaphors. The riddle includes three metaphorical integrations and three backward projections. All these clues will help the riddlee to guess one possible sequent space in which its parts can participate in all of these three conceptual integrations.

Other examples of this group follow this conceptual procedure too. The riddles in this group include two parts of the precedent and sequent, which can be considered as two input spaces. Elements and relations of the input spaces are cross-mapped, and then they are combined and compressed in the blend space. As a result, a metaphorical integration between two different input spaces (precedent and sequent) takes shape, but then this riddle establishes a kind of disanalogy between the spaces. This is done by a backward projection, which 
disrupts the integration and compression of the spaces in the blend spaces. The backward projection is the process that induces a disanalogy and a powerful contrast between the input spaces. So this kind of a riddle first makes a metaphorical integration between the precedent and the sequent, and then makes a disanalogy between them by using a backward projection. We call these riddles discordant metaphors, because they simultaneously prove and deny the metaphorical integration. The following diagram illustrates the conceptual integration of the riddles with discordant metaphors. Symbol X in the diagram refers to the distinctive element highlighted by the backward projection.

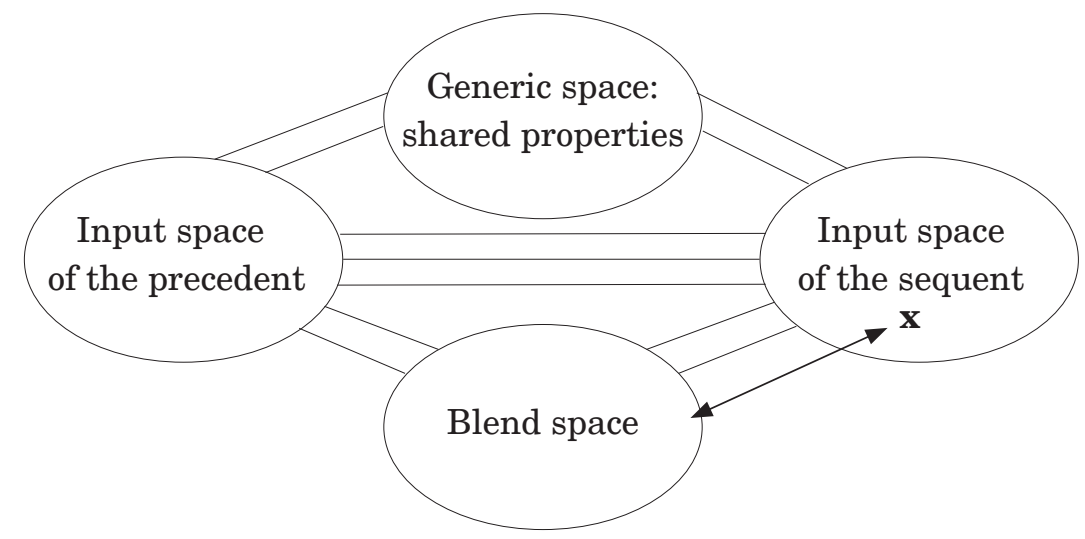

The linguistic structure of these riddles includes two parts; one indicates the metaphorical integration between spaces, and the other states the disanalogy between them made by backward projection. It describes the hidden sequent space as something similar and different in relationship to the precedent space. These concurrent contradictory descriptions bring about the contradictory discourse of these riddles. The linguistic manifestations of these riddles include the precedent space, but do not refer linguistically to the sequent space. The discordant metaphorical riddle as a deliberate metaphor invites the riddlee to guess the hidden space (sequent) in terms of the precedent space via an analogy brought about by metaphorical integration and a disanalogy made by backward projection. The riddlee should guess the hidden space (sequent) by examining those possible spaces that can take part in a metaphorical integration with the precedent space. Although there can be some potential candidates for the sequent space in the riddles, the simultaneous concurrent process (analogy done via metaphorical integration and disanalogy via backward projection) reduces the range of possible candidates to a considerable extent. 


\section{The third group: Non-metaphorical riddles}

The third group comprises 33 percent of the total number of the riddles. The riddles in this group do not use the metaphorical relationship between the precedent and the sequent in their structures. The most common topics of these riddles are mathematical computations, and guessing an object by considering some of its properties described in the riddle. Some riddles, by choosing a non-central member of a category, and by describing its non-prototypical and sometimes pseudo-contradictory properties, ask the riddlee to guess the name of that object. Because they are not shaped metaphorically, we do not delve into them. We hereby mention ten of them:

30. Hana no sini, ba har sini nine nân, la sar har nân no kəfta, la sar har kəft no korpa.

I have nine trays, and nine loaves of bread on each tray, and nine kəftas (a kind of food) on each loaf of bread, and for each $k \partial f t a$, there are nine children to feed. (81 loaves of bread, 799 kəftas, and 6561 children)

31. Se ow penj, pazdaw du, hafdaw sew bist: dakâta čand.

Three and five, fifteen and two, seventeen and three: what is the result? (twenty)

Riddle 31 is based on a tricky computation. The riddle includes a series of figures, and operations like multiplying and adding. The riddler has not mentioned the mathematical operations. This riddle with its mathematical operations looks like: 3 multiplied by 5 equals 15, and 15 plus 2 equals 17, and then 17 plus 3 equals 20 . The riddler has already done the computation without mentioning the operations. The riddlee should discover the implicit mathematical operations in the riddle, namely, he or she should read this riddle by drawing on the mathematical frame.

32. Jâreki la bən âw dačma sar âw.

I suddenly go from the beneath to the surface of the water. (swimming)

33. La qawzay sawztra, la ŝakry sirin tra, la kârabây zardtra.

It is greener than sea wood, it is sweeter than sugar, and it is yellower than hay. (apricot)

This riddle describes some properties of the apricot in the different levels of its development until it is ripe. Apricot is green before ripening, and yellow when it is completely ripe; a ripe apricot may be sweeter than sugar.

34. La new malânda kâmyân ba siira.

Which bird lactates? (bat) 
Bat is a non-central member of the bird category. It is a bird, but produces milk like mammals.

35. Penj farzay be bismilla.

A worship without bismillâ that is done five times a day. (azân)

Muslim's worships begin with bismillâ (in the name of god), but azân is the only worship that is not begun by bismillâ.

36. Mondâli haya balâm məndâli kas nabua.

He has many children, but he is not anyone's child. (Adam)

This riddle refers to the Adam figure in Islam.

37. Bâli nya, helka dakâ.

It has no wings, but it lays eggs. (snake)

The riddlee can guess more than one answer for this riddle. Turtle, lizard, and some others can be good candidates for the answer of this riddle.

38. Helka daka, mriŝk nya.

It lays eggs, but it is not a hen. (turtle)

The riddlee can imagine more than one answer to this riddle too.

39. Ham bukm ham xasum.

I am a daughter-in-law and a mother-in-law.

She is a person whose son has got married, thus she is the mother-in-law to her son's wife, and because her mother-in-law is alive, she is daughter-in-law to her husband's mother. It should be noted that there are some riddles in this group that can have more than one correct answer.

\section{SOME IMPLICATIONS FOR METAPHORICAL GUESSING}

As mentioned above, metaphorical guessing is realized in metaphorical riddles; accordingly, knowledge of the conceptual structure of metaphorical riddles can lead us towards some helpful assumptions about the procedure of guessing in metaphorical riddles. As there are two different groups of metaphorical riddles with different conceptual structures, let us scrutinize the process of guessing in them separately.

As mentioned earlier, the riddles with contingent metaphors are based on metaphorical mapping between the precedent space and the sequent one; the spaces are cross-mapped, and then combined and compressed into the blend 
space. The metaphorical integration between the spaces is motivated by a kind of visual similarity between them. The linguistic manifestation of the riddle includes the precedent space and some of the conceptual correspondences, but it does not refer directly to the sequent space. The riddle as a deliberate metaphor invites the riddlee to guess the sequent in terms of the precedent according to some sort of visual similarity between them. As a result, the riddlee knows that the precedent refers semantically to something beyond itself (hidden sequent) with regard to a possible similarity. He or she knows that the contextual meanings of the used words in the riddle are metaphorically in contrast with their basic meaning.

To find the hidden sequent space, the riddlee should examine those possible candidates for the sequent that may satisfy two conditions; it should bear a resemblance to the precedent space, it may also take part in a metaphorical integration with the precedent. There is more than one candidate that can satisfy these conditions; therefore, several possible candidates for the sequent space can be imagined by the riddlee. Accordingly, the riddlee makes many metaphorical integrations between the precedent space and every possible candidate for the sequent space. By examining different metaphorical mappings between the precedent space and several possible candidates, the riddlee tries to single out the desired option in the riddler's mind. Each of the metaphorical integrations between the precedent and the candidates emerges as a different guess about the riddle. Determining the right candidate is completely dependent on the riddler's decision. Then, it may be argued that the metaphorical guessing is nothing more than deliberately making metaphorical relationship between the precedent space and the possible candidates for the sequent. Consequently, it can be concluded that guessing is itself a kind of deliberate process of making a metaphor. Guessing includes the numerous metaphorizations in order to discover the hidden sequent space in the riddler's mind.

As we pointed out earlier, the riddles with discordant metaphors include two input spaces (precedent and sequent) that are combined and compressed in the blend space, and then a kind of disanalogy between them is made by a backward projection. The linguistic structure of these riddles includes two parts; one indicates the metaphorical integration between the spaces, and the other one indicates the disanalogy between them. The linguistic manifestations of these riddles include the precedent space and some of the conceptual correspondences, but do not refer linguistically to the sequent space. The discordant metaphorical riddle as a deliberate metaphor invites the riddlee to guess the hidden sequent space in terms of the precedent space with regard to the similarity between them. Then, the riddlee knows that the contextual meanings (the sequent) of the precedent space should be interpreted (guessed) 
according to a kind of metaphorical comparison with the basic meanings of the precedent space (the precedent) with regard to a kind of similarity between them. In other words, he or she knows that the precedent refers to a hidden sequent as a result of a metaphorical relationship.

The riddlee tries to guess the hidden sequent space by examining those possible candidates which can take part in a metaphorical integration with the precedent space because of their similarity to the precedent. There would be many possible candidates for the sequent space, therefore the riddlee tries to reduce the number of possible candidates by taking into account the disanalogy made by backward projection. Although the disanalogy highly restricts the number of possible candidates for the hidden space, it is not impossible to imagine more than one answer (hidden space) for some of these riddles. Then, in this group guessing metaphorically is done via several metaphorical integrations between the precedent space and several possible candidates for the sequent as the hidden space. The candidacy of the many potential candidates is conditioned by the visual structure of the precedent space and also by the differences brought about by disanalogy. In this group, guessing is accomplished via a deliberate process of developing a metaphorical relationship between the precedent space and possible candidates for the sequent space.

All in all, it can be concluded that the metaphorical guessing in both groups follows some shared steps. In the first step, the riddlee should take the riddle as a deliberate metaphor; thanks to this presupposition, the riddlee in the second step should imagine all of the possible candidates bearing a kind of resemblance to the precedent space, and can take part in a metaphorical integration with it. The third step refers to making many metaphorical integrations among the precedent space and the possible candidates for the sequent space. Each metaphorical integration emerges as a different guess taken by the riddlee. The fourth step refers to continuing these numerous metaphorizations until the desired sequent in the riddler's mind has been singled out. Then, it may be argued that the metaphorical guessing refers to a deliberate process of making a metaphor between a fixed precedent space and the possible candidates for the sequent space.

However, the process of metaphorical guessing may be guided by some clues and ideas in the riddles. One element of the hidden input space may be verbalized in the linguistic manifestation of the riddle. For example, in example 12 (I have a stable, with a wall of leather, thirty-two sheep are there quietly: mouth, cheek, and teeth), the phrase of with a wall of leather includes an important element of the hidden sequent that may help the riddlee to find the right answer. Also, he or she may use the images presented in the riddle to find the suitable candidates that may be matched with them. But as was already mentioned, the 
clues are always contingent; in other words, they cannot visualize the answer completely. It is the riddlee who should fill out this murky and blurred image by mapping it with all the suitable candidates that have the potentiality to make a metaphorical mapping with the precedent.

Now let us illustrate this metaphorical process of guessing via analyzing a riddle with a contingent metaphor: (kotakayakyân haya ba du mât: two houses have just one column: two nostrils and the septal nasal cartilage between them). The riddlee first considers this riddle as a deliberate metaphor; in other words, he or she knows that the images of the house and the column as the precedent space refer metaphorically to different images as a sequent space according to a kind of visual similarity between the spaces. In other words, he or she knows that the unknown contextual meanings of the words of the house and the column (hidden sequent space) are understood in comparison to their basic meanings (precedent space) according to a kind of similarity between them. Then, the riddlee tries to speculate about different images bearing a kind of visual similarity to the precedent space, and can also participate in a metaphorical integration with it. For example, he or she can imagine some candidates like a cabinet with two parts divided by a wooden column, the nose divided by the septal nasal cartilage, or even as two parts of the lung separated by the trachea. The riddlee examines deliberately metaphorical integrations between the fixed images of the precedent space (two houses and a column) and the various images of the possible candidates (cabinet, nose, and lung) for the sequent space. Accordingly, three different metaphorical conceptual integrations come into existence that are manifested as different guesses taken by the riddlee. He or she develops metaphorical relationships among the precedent space and the possible candidates until finding the right option. So, answering the riddle is done via deliberately making metaphorical relationships among the precedent space and the possible candidates for the sequent.

\section{CONCLUSION}

This study indicated that a considerable quantity of riddles in Kurdish are metaphorically shaped. Their compositions are shaped via different metaphorical conceptual integrations. The riddles in the first group (contingent metaphors) include the precedent and sequent spaces as input spaces that are cross-mapped, and then combined and compressed in the blend space. This metaphorical riddles are not motivated by any kind of correlation-based experience, but they are motivated by resemblance. Considering their potentiality for having more than one correct answer, they are called contingent metaphors. The riddler asks 
the riddlee to guess the sequent by examining different mappings between the precedent space and many other different spaces as possible candidates for the sequent. The riddlee can imagine several possible candidates for the sequent space, but this possibility is restricted by the image-conceptual structure of the precedent space. The second group contains discordant metaphors that are shaped by a complicated metaphorical integration. Firstly, these riddles develop a metaphorical integration between two different input spaces (precedent and hidden sequent), and then make a disanalogy between spaces by a backward projection. One part of the linguistic structure of this riddle indicates the metaphorical integration, and the other one shows the disanalogy. The two processes of metaphorical integration and backward projection restrict the numerous possible answers to the riddle to a considerable extent. The sameness and the difference brought about by these processes provide two different clues for the riddlee to guess the right answer. The riddlee should guess the hidden input space (sequent) by taking into account the metaphorical integration and the disanalogy. Discordant metaphors can provide both similarities and differences simultaneously. The third group is not shaped by any metaphorical integration. These non-metaphorical riddles just show some properties of an object and ask the riddlee to guess the object. Considering the conceptual structures of the metaphorical riddle, it is argued that the metaphorical guessing related to the metaphorical riddles is specified by some cognitive procedures. First, the riddlee takes the riddle as a deliberate metaphor. Then, he or she should imagine the possible candidates for the sequent space capable of participating in a metaphorical integration with the precedent space according to a kind of similarity between them. After that, he or she develops many metaphorical relationships between the precedent space and the possible candidates for the hidden sequent space. The process of numerous metaphorizations continues until the intended option has been singled out in the riddler's mind. The metaphorical guessing is defined as a deliberate process of making a metaphor between a fixed precedent space and various possible candidates for the hidden sequent space.

\section{NOTE}

1 In modern Kurdish society, television and other forms of media have replaced the ancient forms of entertainment (riddle and storytelling) in the Kurdish families. 


\section{REFERENCES}

Ahmadi, Ebrahim 2010. Farhangi Matalu Moamma la Kurdi. [Dictionary of Puzzles and Riddles in Kurdish.] Sanandaj: Entesharat Elmi Kalej.

Ben-Amos, Dan 1976. Solutions to Riddles. The Journal of American Folklore, Vol. 89, No. 352, pp. 249-254. http://dx.doi.org/10.2307/539691.

Dienhart, John M. 1999. A Linguistic Look at Riddles. Journal of Pragmatics, Vol. 31, No. 1, pp. 95-125. https://doi.org/10.1016/S0378-2166(98)00056-3.

El-Sharif, Ahmad 2012. Metaphors We Believe by: Islamic Doctorine as Evoked by the Prophet Muhammad's Metaphors. Critical Discourse Studies, Vol. 9, No. 3, pp. 231-245. http://dx.doi.org/10.1080/17405904.2012.688209.

Fauconnier, Gilles \& Turner, Mark 2002. The Way We Think: Conceptual Blending and the Mind's Hidden Complexities. New York: Basic Books.

Gomola, Aleksander 2010. From GOD IS A FATHER to GOD IS A FRIEND: Conceptual Integration in Metaphors for God in Christian Discourse. In: E. Tabakowska \& M. Choinski \& L. Wiraszka (eds.) Cognitive Linguistics in Action: From Theory to Application and Back. Berlin \& New York: Walter de Gruyter, pp. 387-408.

Grady, Joseph 1999. A Typology of Motivation for Conceptual Metaphor: Correlation vs. Resemblance. In: R. W. Gibbs \& G. J. Steen (eds.) Metaphor in Cognitive Linguistics. Amsterdam \& Philadelphia: John Benjamins Publishing Company, pp. 79-100. https://doi.org/10.1075/cilt.175.06gra.

Green, Thomas A. \& Pepicello, W. J. 1984. The Riddle Process. The Journal of American Folklore, Vol. 97, No. 384, pp. 189-203. http://dx.doi.org/10.2307/540184.

Harries, Lyndon 1971. The Riddle in Africa. The Journal of American Folklore, Vol. 84, No. 334, pp. 377-393. http://dx.doi.org/10.2307/539632.

Harries, Lyndon 1976. Semantic Fit in Riddles. The Journal of American Folklore, Vol. 89, No. 353, pp. 319-325. http://dx.doi.org/10.2307/539444.

Khaleqi Mutlaq, Jalal 2002. Sukhanhaye Dirineh: Si Guftar dar Bareye Ferdowsi va Shahnameh. [Ancient Discourses: 30 Essays on Ferdowsi and Shahnameh.] Edited by Ali Dehbashi. Tehran: Afkar.

Köngäs-Maranda, Elli 1971. The Logic of Riddles. In: P. Maranda \& E. K. Maranda (eds.) Structural Analysis of Oral Tradition. Philadelphia: University of Pennsylvania Press, pp. 198-232.

Kovecses, Zoltán 2004 [2000]. Metaphor and Emotion: Language, Culture and Body in Human Feeling. Cambridge: Cambridge University Press.

Kovecses, Zoltán 2005. Metaphor in Culture: Universality and Variation. Oxford \& New York: Cambridge University Press.

Kovecses, Zoltán 2010 [2002]. Metaphor: A Practical Introduction. Oxford \& New York: Oxford University Press.

Lakoff, George 2007. The Contemporary Theory of Metaphor. In: V. Evans \& B. Bergen \& J. Zinken (eds.) The Cognitive Linguistics Reader. London \& Oakville: Equinox, pp. 267-315.

Lakoff, George \& Johnson, Mark 2003 [1980]. Metaphors We Live By. Chicago \& London: University of Chicago Press. 
Pragglejaz Group 2007. MIP: A Method for Identifying Metaphorically Used Words in Discourse. Metaphor and Symbol, Vol. 22, No. 1, pp. 1-39. http://dx.doi. org/10.1080/10926480709336752.

Rapone, Amanda 2012. Metaphorical Riddles as Conceptual Blends: A Look at the Riddle Solving Process. Language and Creative Mind. 11th Conceptual Structure, Discourse, and Language Conference. Vancouver, British Columbia, May 17-20, 2012. Available at http://csdl2012.sites.olt.ubc.ca/2012/04/16/metaphoricalriddles-as-conceptual-blends-a-look-at-the-riddle-solving-process/, last accessed on 12 September 2018.

Sarseyfi, Reza 2010. Pandi Peshiniani Kurdi: Masal, Matalu Benarati Masalay Kurdi. [The Wisdom of Ancient Kurdish People: A Dictionary of Kurdish Advice and Riddles.] Saqqhez: Gotar.

Shohani, Alireza 2014. Tabaqebandiye Chistane Amianeye Ilami. [The Classification of Ilami Riddles.] Majalleye Farhang va Adabyate Amme [Journal of Culture and Folk Literature], pp. 135-158.

Steen, Gerard 2011. From Three Dimensions to Five Steps: The Value of Deliberate Metaphor. Metaphorik.de, Vol. 21, pp. 83-110. Available at https://www.researchgate. net/publication/235325095/download, last accessed on 7 September 2018.

Weiner, E. Judith \& Palma, Paul de 1993. Some Pragmatic Features of Lexical Ambiguity and Simple Riddles. Language and Communication, Vol. 13, No. 3, pp. 183-193. http://dx.doi.org/10.1016/0271-5309(93)90025-I.

Zolfaqhari, Hasan 2013. Rikht Shenasiye Chistanhaye Manzume Mohalli. [Morphology of Local Poetic Riddles.] Majalleye Farhang va Adabyate Amme [Journal of Culture and Folk Literature], pp. 93-118. 


\section{NEWS IN BRIEF}

\section{COLLECTING ACTION “SCHOOL LORE 2018” EXCEEDED}

\section{ALL EXPECTATIONS}

The all-Estonian school lore collecting action took place from 24 February to 24 May 2018, with a record number of participants: answers to questionnaires were sent by 3717 respondents and additionally material was collected in the form of 'pupil to pupil' interviews. Answers were expected from the pupils of the 4th to 12th grades (incl. those from vocational schools), and most of them answered electronically. In addition to Estonian- and Russian-language schools in Estonia, some answers were also sent from Estonian schools abroad (mainly Finland).

The patron of the project, initiated by the Department of Folkloristics of the Estonian Literary Museum, was the Tartu City Writer Mika Keränen, and "School lore 2018" was recognised as an event of the European Year of Cultural Heritage. The pilot phase in December 2017 yielded over 300 filled questionnaires. The main stage was geared up in March 2018 with a training day for schoolteachers, under the heading "Killer clowns, protective angels, and YouTubers: School lore 2018", which gave an overview of the current situation and discussed why and how school lore should be collected.

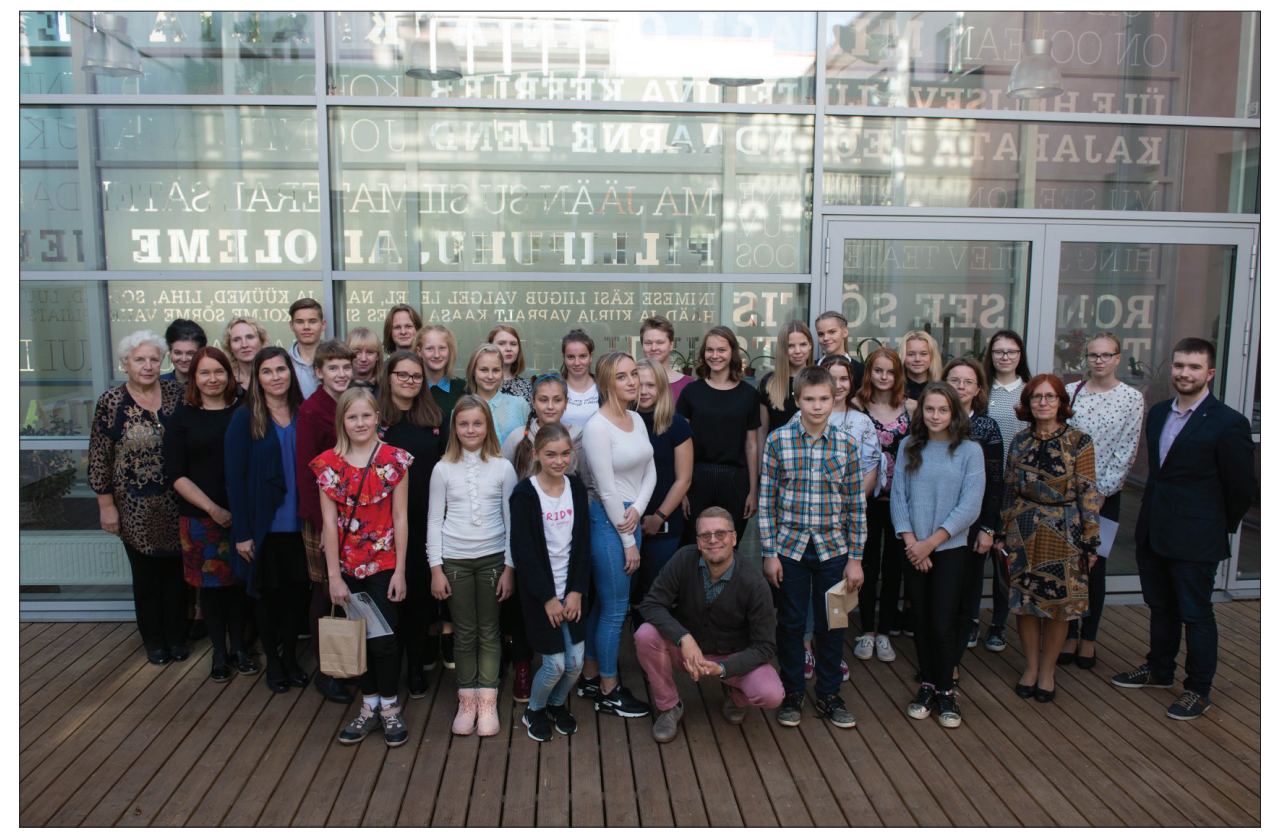

School lore collectors at the Estonian Literary Museum. Photograph by Alar Madisson 2018. 
In both the pilot and main phases, schoolchildren were more prone to answer questions about names (nicknames, pets' names), leisure time, fandom, as well as fears and protective beliefs. Questions about celebrating various holidays yielded shorter answers. The main phase offered a good overview of today's humour use (e.g. through materials from meme creators and -fans). Several traditional joke models were revised in somewhat updated format (e.g. the blonde jokes, three-nation jokes, etc.).

As could be expected, the most popular holidays in Estonian homes are Midsummer Day and Christmas; birthday celebrations tend to decline in importance. The descriptions of school traditions involved fascinating local traditions and intertwining with older lore.

In the answers about games played, many past favourites were highlighted; however, in comparison to the previous collection action in 2007, the importance of computer games had considerably increased. As a new form of play, imitating the plots of computer games or TV-series was mentioned.

The fears brought out were a mixture of psychological, real life, and supernatural fears, with strong media influence as could be expected, involving killer clowns, darkness, spiders, UFOs/aliens, and ghosts. Additionally, a number of respondents admitted they believed in the existence of aliens, yet did not express fear for them.

The general atmosphere of the material was friendly and positive. Although pupils described several fears, they were also aware of either realistic or supernatural ways for fighting them (with the help of protective spirits and items, charms, positive autosuggestion, supportive kin). So the obtained material yielded a vivid picture of today's youngsters' thoughts, feelings, and beliefs, resulting in an expressive document of the era, offering valuable material also to future researchers.

Reet Hiiemäe

\section{POLAR READINGS 2018 ON BOARD THE KRASIN ICEBREAKER}

On 27 and 28 April 2018, an international conference under the heading "Polar Readings 2018: Technology in the history of the Arctic development" was held aboard the icebreaker Krasin. The conference was held for the sixth year, before the annual Icebreakers Festival on the River Neva, organized by the Museum and Exhibition Center for Technical and Technological Development of the Arctic (Arctic Museum and Exhibition Center) and the department of the Museum of the World Ocean at Saint Petersburg, "The Krasin Icebreaker". Scholars representing different scientific disciplines, museums, and archives, as well as public figures and any concerned participants gathered in the historical interior of the famous ship.

The exact subject of Polar Readings changes every year; in 2018 it was titled "Practices and equipment in Arctic exploration". The aim of the conference was to summarize the historical experience concerning the topic. The organizers declared a wide range of 
scientific directions from the history of technological thought of different times to the mechanisms of environmental management and survival in the Arctic regions. The conference program included 50 reports, not divided into sections, so there were busy schedules on both days. Thanks to this, representatives of different disciplines (archaeologists, historians, museum experts, geographers, biologists, engineers) were able to listen to each other's presentations and join in fruitful discussions within certain directions, which was one of the organizers' aims.

Polar Readings discussed the technical features of the organization of research expeditions and the development of the Arctic region in the 19th and beginning of the 20 th centuries. Considerable attention was paid to the analysis of various types of equipment (icebreakers, research ships, polar aircrafts, all-terrain vehicles, submarines, etc.) used in the history of the complex development of the Soviet Arctic. A whole set of presentations focused on the problems of searching, preservation, and restoration of the objects concerned with the technical development of the Arctic.

We would like to address in greater detail the reports of the anthropological block. All of them studied the problem of functioning of the system of traditional environment interactions and life support of the indigenous peoples of the North in the context of new social and economic processes in modern Russia. V.N. Davydov (Peter the Great Museum of Anthropology and Ethnography (the Kunstkamera)) explored the modern technologies for the mastering of environment, performed by the indigenous peoples of the Arctic through the rational use of ambient resources and new energy regimes. A.Y. Chistyakov and S.B. Kiselev (EthnoExpert company) focused on the interaction of the Yamal LNG with the Nenets reindeer herders of the Yamal Peninsula. A.N. Terekhina (Peter the Great Museum of Anthropology and Ethnography (Kunstkamera)) and A.I. Volkovitskiy (Centre of Arctic and Siberian Exploration of the Sociological Institute of the Russian Academy of Sciences) examined the problem of using the term 'snowmobile revolution' in different Arctic regions, and various practices of using snowmobiles in the modern culture of the Yamal Nenets. E.A. Davydova (Peter the Great Museum of Anthropology and Ethnography (Kunstkamera)) introduced the transformations of technologies for storing and cooking food in Chukchi culture. O.B. Stepanova (Peter the Great Museum of Anthropology and Ethnography (the Kunstkamera)) presented the study of modern northern Selkup camp as an element of anthropogenic landscape. Y.M. Plyusnin (Higher School of Economics) summarized his explorations of life support strategies and people's crafts of the Russian North population in the 20th - beginning of the 21st centuries.

On the second day, the participants of the Polar Readings 2018 discussed and worked out a resolution containing recommendations and appeals to authorities, research organizations, and other stakeholders.

The successful work of the conference, and its schedule in particular, forms a certain direction for analysis. We understand that the theme of these Polar Readings implied a bias towards the history of polar technology and the technological development of the North, but we were primarily interested in the context focusing on the indigenous peoples of the Arctic. The correlation of the report topics and a further discussion between the participants demonstrated, of course unwittingly, the general model of representations of the Arctic in modern Russia: key directions of development, priorities, and statuses of various actors. 
In addition to six specialized anthropological approaches described above, only three papers addressed the 'aboriginal' theme. Archaeologists V.V. Pitulko (Institute for the History of Material Culture of the Russian Academy of Sciences) and S.V. Gusev (Russian Institute for Cultural and Natural Heritage named after D.S. Likhachev) described the Stone Age technologies in the archaeological sites of the Arctic. M.V. Titova (Museum of Art Development of the Arctic named after A.A. Borisov, Arkhangelsk) presented archival data concerned with the artistic expedition of A.A. Borisov to Novaya Zemlya, with a reference to the local Nenets depicted on his canvases.

It is well known that the success of Arctic expeditions, starting from the 18th century, was significantly connected with the fact that travelers and explorers used technologies of adaptation of indigenous peoples of the northern latitudes: clothes, food, transport, etc. Local people were hired as guides, carriers, interpreters. During the Soviet period, the indigenous peoples were also irreplaceable participants in the social and technical development of the North. Unfortunately, such a view was not presented in any speech at the conference. Thus, the culture of the indigenous peoples stagnates within the frames of 'prehistoric antiquities' or 'exotic culture' against the background of the conquest of Arctic vastness by pioneers, or industrial development, the achievements of polar technology, which are inherent in the colonial approach, that acquired new forms in the 21st century. We have seen many times that in Russian federal media the Arctic topic arises, as a rule, only in connection with the building of a new industrial facility, or pumping of hydrocarbons, launching a new icebreaker or constructing a military base - strategic projects of high priority for Russia. Indigenous peoples appear in the context of supporting the 'traditional lifestyles' by industrial companies, similar to the conservation of the population of polar bears.

Moreover, at the interdisciplinary conference, once again we witnessed how the approaches of different scientific disciplines are far from the approaches, methods, and discourses of each other and especially from ours - anthropological. Presentations focusing on the Nenets' use of snowmobiles or the modern nutrition of Chukchi provoked non-anthropologists to criticize technical and technological innovations as interventions destroying the 'traditional' culture of indigenous peoples. We claim that such a reaction only supplements the 'colonial' image of an aborigine and also denies the possibility of partnerships and the equality of human capabilities.

No doubt such conferences are of great importance for the cross-disciplinary interaction and, if we may say, for the popularization of the anthropological view of the problems of the indigenous peoples of the North.

\section{Acknowledgements}

This review was supported by the Russian Science Foundation (project № 18-18-00309).

Olga Stepanova, Alexandra Terekhina

Peter the Great Museum of Anthropology and Ethnography (the Kunstkamera) 


\section{CONFERENCE ON FOLK NARRATIVES IN RAGUSA}

On 12-16 June 2018, the interim conference of the International Society for Folk Narrative Research (ISFNR), titled "Folk narrative in regions of intensive cultural exchange" took place in Ragusa, Italy. In the globalised era cultural exchange is becoming increasingly intensive in many areas, therefore the title of the conference called participants to discuss comparatively about a multitude of views, methods, and motives relevant in the field of folk narrative research. The transmission and ensuing transformation of narratives over time is subject to processes of selection and assimilation, and these processes fulfil various purposes. The papers of the conference showed that such narratives can help people to maintain or adapt their cultural and religious identities, to protect themselves mentally in the times of crisis, to find ways for overcoming traumas, etc. The conference offered a platform for an interdisciplinary approach, initiating discussions on various theories, models, and definitions, types of storytellers and storytelling events, the role of migration and mass media in cultural exchange, etc.

Within the framework of the ISFNR conference, the Belief Narrative Network (BNN) organised a subconference with the topic "Human-animal relationships in belief narratives". The overview below focuses on this subconference. It was pointed out in the introduction to the conference that most current histories tend to treat the human and animal realms as separate, but such a vision is only part of what the human mind has produced as a whole. A closer look at respective narratives shows that the human and the animal world may often merge (e.g. in the case of animal metamorphoses, soulanimals), and the symbolic role of animals is much more important in the cultural and societal thinking than many of us may have thought. The conference attempted to include a scope as wide as possible, ranging from the contemporary Western cultures to ancient regional practices, from collective to individual realms, enabling perspectives from folklore, language, literature, art, and sexuality to psychology and psychopathology.

Quite expectably, several papers concentrated on narratives related to werewolves and other wereanimals. Aðalheiður Guðmundsdóttir talked about the double nature of the werewolf in Iceland, which has actually always been a wolf-free country, trying to track the origins of respective tale motifs. Terry Gunnell argued in his paper that early settlers of Iceland brought beliefs in shape-shifting with them and were also familiar with the belief of people being born with their protective animal (fylgjur) which followed them throughout their lives. According to Gunnel these beliefs continued to be passed on as part of sagas and rimur ballads but soon lost their importance in folk legends. Another paper (by Romina Werth) exemplified the role of the man-bear (berserkr) in the Icelandic context, looking at the texts of medieval Icelandic prose and later fairy tales and concluding that being a berserkr referred, first and foremost, to a change in the state of the human mind without an actual shape-shifting, but certain folktales can still also include the bodily metamorphosis.

Based on her recent fieldwork in Bosnia and Herzegovina, Miriam Mencej pointed out the social uses of narratives about werewolves. Margaret Lyngdoh continued the topic of the social functions of respective beliefs in the context of northeast Indian folklore, using the example of sangkhini - certain human-animal shapeshifters that are described as having the body of a snake and the head of a bull. Lyngdoh's paper was also a reflection of her recent fieldwork. Dilip Kumar Kalita proceeded with examples 
from northeast Indian folklore, showing how narratives about human transformations into pythons, ducks, tortoises, dogs, and tigers are mostly considered as belonging to the narrative realm, but can sometimes be still taken as facts and thus create social tensions. Shailesh Kumar Ray attempted to give a critical historical analysis of human-animal relationships in the Indian epic Ramayana, inferring that in this epic context mythological animals were mostly described in a humanised form, and their relationship with humans was depicted in an idealised way. Kinga Markus Takeshita focused on the tensions between the perception of snakes as characters with supernatural wisdom, and as the embodiment of evil in the Iranian national epic, in classical mythology, and in Middle Eastern folk narratives. Lidija Bajuk added, on the basis of Croatian folk narrative material, that the perceptions of animals were to a great extent based on real-life observations, but were at the same time influenced by folkloric motives and symbolism.

Two papers (Vita Dzekcioriute and Jelka Vince Pallua) concentrated specifically on the role of the frog in belief narratives, giving an overview of the female symbolism of this creature and exemplifying how in some cases a small and harmless animal can obtain significant narrative power, attracting a wide and abstract complex of beliefs. Similarly, rich folklore has centred around cockroaches. Suzana Marjanić gave an overview of the exhibition "Cockroaches - A Lingering World" in the Croatian Natural History Museum, but also described how these insects have been depicted in belief narratives and art, their role fluctuating between hated parasites and heroic animals that can bring prosperity and survive even the nuclear war. Nidhi Mathur added a literary perspective, attempting to critically analyse the relationship between humans and animals in Hermann Hesse's Tales with a theoretical perspective of human-animal studies, storytelling, and conflict theory. Laura Jiga Iliescu offered an outlook on apocryphal texts that describe the dream of the Mother of God. Iliescu analysed the relationship between the content of these texts and their oral performance as a source of intertextual interferences between oral and literary cultural expressions; she also pointed to the role of the oracular sheep in these texts.

Fumihiko Kobayashi's paper offered a glimpse of pre-modern Japanese views of animal societies and their abstraction into an unattainable dream-world or paradise, using the narrative motives related to the underground mouse paradise (nezumi jōodo) as a point of departure. Kobayashi showed how such narratives can serve as an expression of unfulfilled desires for wealth and prosperity. Reet Hiiemäe looked at a very spiritual and symbolic type of animal-human relationships, describing how contemporary Estonian narratives about contacts with soul-animals are used as a mechanism of self-help and positive life history narrating. Tok Thompson talked about Native American myths, seeking to connect the current theoretical movements in post-humanism with those in mythology. He pointed out that many of these new scholarly concepts about animal agency and culture actually have their vernacular counterparts in the Native American traditional narratives. Andres Kuperjanov gave an overview of the Estonian rich belief narrative tradition about trees.

The conference also offered some general papers about classification, genre, and novel theoretical approaches. Maria Ines Palleiro described problems concerned with classifying Argentinian animal tales, for sometimes internationally known animal tales transform locally into belief narratives. Thus, she showed how in some cases local beliefs transform universal tale types into expressions of local cultural identities. Desmond 
L. Kharmawphlang analysed the supernatural beliefs of a northeast Indian modern urban community, exemplifying the rhetoric and other techniques through which those beliefs are presented. Focusing on narratives about the relationship of beautiful water spirits (puri) and men, he attempted to trace an ecocritical discourse in this phenomenon. Kristel Kivari focused on the role of senses in narrating belief narratives, using the example of contemporary Estonian dowsing lore. Mare Kõiva exemplified, on the basis of a cycle of narratives, political disruptions of 1905, and showed how fear and shame find their expression through repeated narrating. Anoop Vellani talked about beliefs and belief narratives related to certain South-Indian female vampires (Yakshis). Vellani viewed respective narratives as an example of constructing local and political histories out of the imprinted memories and imageries of the magical world.

Sandis Laime offered a glimpse of the popular motives of the northeast Latvian raganas tradition - a supernatural tradition that today has almost entirely vanished. Laime tried to find out about possible migration routes of the two main versions of this tradition. Rahmonov Ravshan gave his paper about mythological stories of Tajik people and pointed to the problem that often rich supernatural traditions are not sufficiently documented in their active phase, which makes their historical research difficult. However, he could still present some fieldwork materials and documentaries of storytelling. JoAnn Conrad gave an overview of her project that aims to review the data on trolls in Scandinavia, using collections, children's magazines, and also archival material (e.g. special interactive maps) in order to update the typology of trolls, but also to investigate the interplay between the written and oral sources. Finally, Ülo Valk talked about the relationship of the supernatural and laughter, using the concept of "appropriate incongruity" while analysing the role of laughter and humour in telling legends.

As a conclusion, it can be said that the conference widened the possibilities of viewing and understanding culture and society through numerous examples pointing to the importance of the animal perspective. Thus, the conference surely fulfilled its original objectives.

Reet Hiiemäe 


\section{BOOK REVIEW}

\section{ALLITERATIVE HISTORIES}


Ian Cornelius. Reconstructing Alliterative Verse: The Pursuit of a Medieval Meter. Cambridge: Cambridge University Press, 2017. 219 pp. ISBN 9781107154100.

Geoffrey Russom. The Evolution of Verse Structure in Old and Middle English Poetry: From the Earliest Alliterative Poems to Iambic Pentameter. Cambridge: Cambridge University Press, 2017. 316 pp. ISBN 9781107148338.

Eric Weiskott. English Alliterative Verse: Poetic Tradition and Literary History. Cambridge: Cambridge University Press, 2016. 236 pp. ISBN 9781107169654.

The appearance of three substantial works on alliterative verse in quick succession from Cambridge University Press is a testimony to the emergence of fresh insights in this area. Scholars have clarified in recent years the metrical constraints applying in later English alliterative verse, and one in particular has provided a historical account of how these constraints emerge from the earlier workings of alliterative metre in English. This work has cleared the ground for this surge in interest. The burst of Cambridge publications is particularly noteworthy given that their last title with 'alliterative' or 'alliteration' in the title is from 2003, which also appears to be the only(!) work with such a keyword in its title from this press.

All of the three books under review take a long view of the subject - Russom even begins with Indo-European - but none goes further than the sixteenth century, which is when alliterative metre disappears in English. Disappearance is not a new thing - there is a period of two and a half centuries from about 1100 on, where the written record is extremely spotty. For the last half century or so of scholarship, the idea of metre surviving this period has been dismissed, even, at worse, seen as a national-romantic delusion, but one of the most remarkable aspects of the new scholarship is that it is now respectable once again to speak of survival. (Deliciously, Weiskott even historicizes this anti-survival attitude as part of the academic politics of that time, namely the defence 
and consolidation of Middle English studies.) Nicolay Yakovlev has produced an account of how Middle English metre, which he sees as accentual, derives from Old English 'morphological' metre via the hybrid forms we see in the early Middle English Brut. This influential account depends upon continuity for its explanatory power. Yakovlev's work is the key influence behind especially the books of Cornelius and Weiskott (Russom seems not to have digested it, although his thinking has some points of contact with it). It is somewhat of a surprise that a $\mathrm{PhD}$ thesis should be so influential, and that it has not reached book form in the decade since the thesis was defended a decade ago at Oxford. In lieu of this, Weiskott provides a useful summary of Yakovlev's thinking in the early pages of his own book.

Another innovative aspect of the new scholarship is that it sees alliteration not as metrical but as decorative. Given we do not get poems in this metre that do not alliterate, this comes over as counter-intuitive. Although all the books under review have a broad diachronic sweep, they do not look very far afield to other alliterative traditions. If they had, they might have found that the same question of whether alliteration is metrical had been addressed by scholars working on Baltic-Finnic alliterative verse. For example, the account that Leino provides of Baltic-Finnic alliterative metre notes that even though lines without alliteration occur, "the alliteration rule belongs to the metrical part of the grammar" (1986: 134).

Cornelius in his book has both metrical and historiographical concerns. Much of the work is concerned with the historical "pursuit" of the metre's underlying principles. In his treatment, we are presented with a fascinating tragi-comedy of errors involving medieval authors, who were either not concerned to describe what they knew, or who did so only fleetingly and in a way overly-influenced by Latin paradigms and terminology, who were then followed by belated early modern and modern scholars who were very much stumbling to an understanding. Cornelius is highly sceptical about the sources, and even dismisses what had been hailed by as the insider's view of James VI and I as itself being an already-belated misinterpretation. Yet his account of all this misunderstanding is not a pessimistic one, as he (and others) now see English alliterative verse as an expanding research field, where right knowledge is finally being established.

Russom's book, although his title includes the word "iambic pentameter", is chiefly focused on the alliterative tradition, indeed on some of this tradition's minutiae ('Middle English Type A1 and the Hypermetrical B-Verse' is a sample chapter title). At the same time, he is keen to deploy a "universalist theory of poetic form" (p. 5). This is a new field, and it is not yet clear how universal such universals are in practice. For instance, the universal word constraint states that "the average number of words per line must be no greater than nine and is usually no smaller than five" (p. 20), and as an example of this gives a line of Shakespeare with 7 words. But we do not have to look too far to see this "universal" is not so universal. I have an Estonian poetic text beginning "Sõeru, sõeru, lehmakene," open on my computer - in its seventeen lines, only two meet the so-called minimum of 5 words. The remainder are six 4 -word lines and nine 3 -word lines. In the same tradition, 2-word lines are also possible: "Neiukene, noorukene". Yet, if we take the number of syllables, there is far less of a difference: 8 in the Estonian example, 10 in the Shakespearean pentameter. Later on, on page 59, Russom presents an excerpt from Beowulf where there is, as he says, an average of four words per line. But if we count 
syllables, we find 8-11 per line once again. Wouldn't a formulation of transcultural syllable constraint per line be more useful? We might treat two other supposedly universals more briefly, the introductory principle and the principle of closure, which state there is great regularity at the opening and closings of units. Isn't the opposite true just as often? Consider the extra syllables at line-starts and line-ends in the English pentameter, and consider how unusual openings and closings of poems as a whole often are when compared with the body of a poem.

Weiskott's book is the one that had the strongest impact on me, given that it can most convincingly be read as defence of the honour of the alliterative tradition and its dynamism. It emphasizes the variety of styles within the tradition, and the influence of this tradition on other traditions, which lead to the invention of various hybrid forms. He also sees the death of this metre as non-inevitable. This contrasts with an account such as Russom's, which essentially says that the substantial linguistic changes in English rendered the metre obsolete (he fingers particularly the development in word order from SOV to SVO). But language change can only be part of an explanation - alliterative metre had successfully adapted to substantial linguistic change before. Cornelius' chief explanation is that alliterative metre grew imperceptible as metre, it was heard as an eccentric version of the new standard metre: "we might say that alliterative verse did not so much die as suffer reinterpretation" (p. 146). Other factors are important here as well, including cultural fashion and domain loss, and once again attention to metrical death in other cultures could shed light on the matter (e.g. Roper 2009).

Reading Weiskott's account as someone interested in the history of folklore studies is interesting as it soon becomes apparent that he is in favour of using biological metaphors to describe his material and against using linguistic ones. If we think of the current orthodoxy in folklore studies (Hafstein 2001) where the use of biological metaphors is taken to be a misleading practice that should be consigned to the past, then this is a bracing view.

Weiskott also publishes an extraordinary work I knew nothing of - a twelfth-century translation of the Old English alliterative poem Brunanburh into Latin. He claims (although he notes it "requires certain assumptions" (p. 183)) that the translator, Henry of Huntingdon, is trying to recreate twelfth-century English alliterative metre in his Latin text. If Henry is really trying to emulate all the relevant features then the presence of only incidental alliteration in the target-language text might suggest alliteration really was seen as decorative, although the task is an immense one, and not everyone can show the versatility that Tuomo Pekkanen did in his largely alliterative rendering of The Kalevala into Latin (1996).

Weiskott in his Conclusion calls out a figure such as James Fenton who has claimed that alliterative verse "is somebody else's poetry" (p. 168). Inasmuch as Fenton might be called Audenesque, at least as his verse style is concerned, the parochialism of his views betrays a substantial difference between him and his predecessor as Professor of Poetry at Oxford. One reason for Auden being so different from the 'Audenesque' Fenton is that the former is familiar with Old and Middle English (and indeed with Norse) alliterative verse - at one stage he said one of his three major poetic influences was William Langland (the others being Dante and Pope). The frivolous aspect of Auden would have been all the greater without such a counterweight to Pope that figures such as Langland and Dante provide. This danger is not one unique to Auden amongst English poets. 
To sum up, this sudden revival in scholarship on alliterative verse is a very welcome development. All three books form important contributions to the ongoing debate. All of these books stop, however, in the sixteenth century. There has been alliterative verse written in English since then, most especially in the twentieth century, including works from the pens of such distinguished names as Tolkien, C. S. Lewis, and indeed Auden. These attempts, metrically at least, hark back strongly, too much maybe, to the norms of the past rather than remaking the metre for our day. Perhaps there are more clues as to how it could be done nowadays might be found in the alliterative work of Richard Wilbur and of Hopkins. In any event, it may be that it is not just the study of historical alliterative verse that is undergoing a revival.

\section{References}

Hafstein, Valdimar 2001. Biological Metaphors in Folklore Theory: An Essay in the History of Ideas. Arv: Nordic Yearbook of Folklore, Vol. 57, pp. 7-32.

Leino, Pentti 1986. Language and Metre: Metrics and the Metrical System of Finnish. Helsinki: Suomalaisen Kirjallisuuden Seura.

Pekkanen, Tuomo 1996. Kalevala Latina. Helsinki: Kalevalaseura \& Suomalaisen Kirjallisuuden Seura.

Roper, Jonathan 2009. On Finnic and English Alliterative Metres. In: Matti Kilpiö \& Leena Kahlas-Tarkka \& Jane Roberts \& Olga Timofeeva (eds.) Anglo-Saxons and the North. Tempe, Ariz.: Arizona State University, pp. 89-108.

Jonathan Roper 

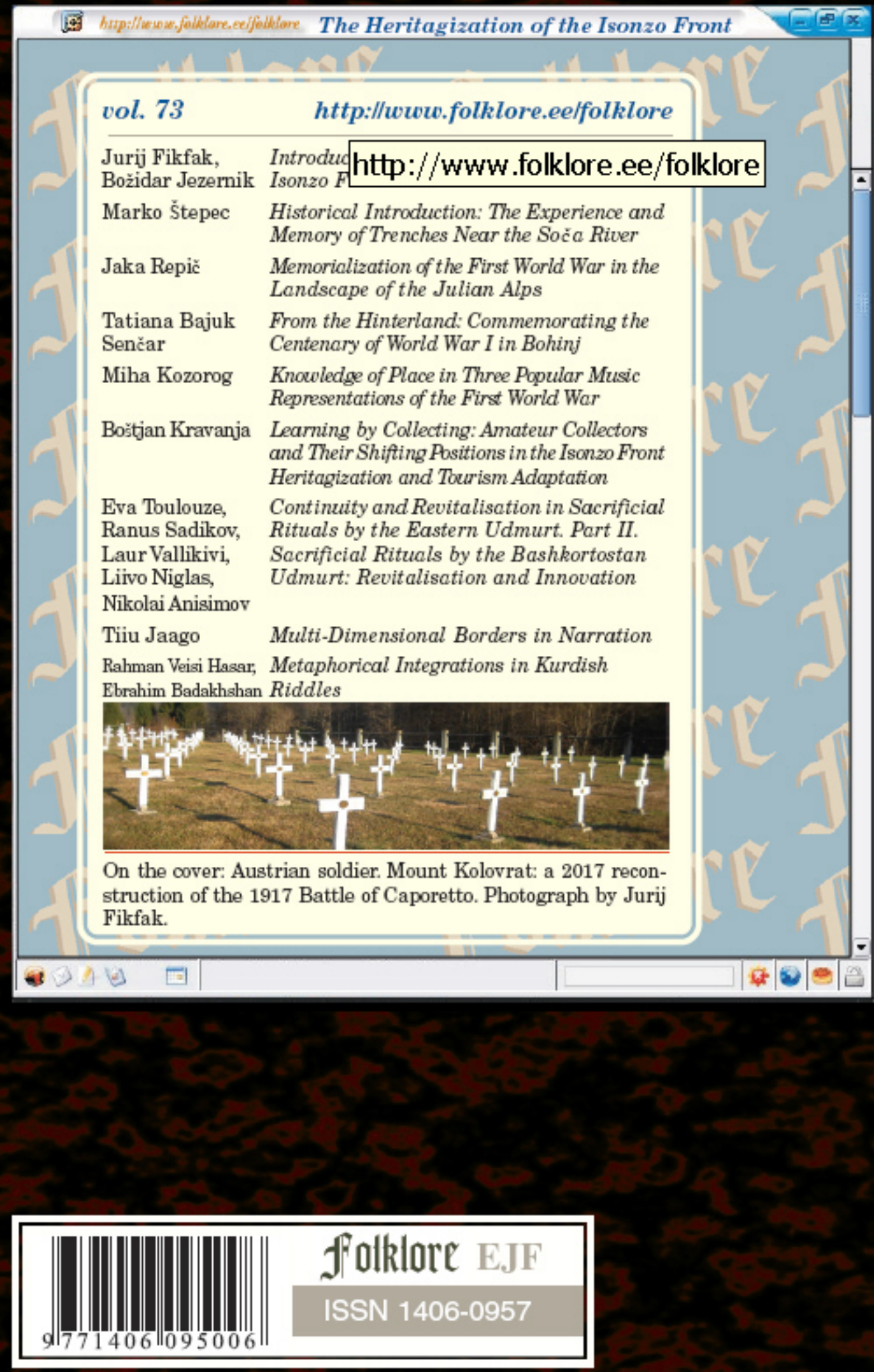